UNIVERSIDADE DE SÃO PAULO

FACULDADE DE FILOSOFIA, LETRAS E CIÊNCIAS HUMANAS

DEPARTAMENTO DE HISTÓRIA

PROGRAMA DE PÓS-GRADUAÇÃO EM HISTÓRIA SOCIAL

TIAGO SANTOS ALMEIDA

Georges Canguilhem: combates pela história das ciências

(Versão corrigida) 


\section{Georges Canguilhem: combates pela história das ciências}

(Versão corrigida)

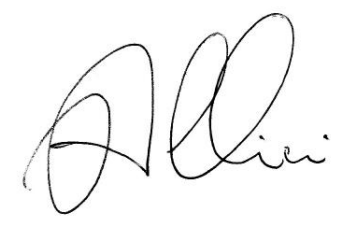

Com o acordo da orientadora

Tese apresentada à Faculdade de Filosofia, Letras e Ciências Humanas da Universidade de São Paulo para obtenção do título de Doutor em História.

Área de concentração: História Social Orientadora: Profa. Sara Albieri 
Autorizo a reprodução e divulgação total ou parcial deste trabalho, por qualquer meio convencional ou eletrônico, para fins de estudo e pesquisa, desde que citada a fonte.

Catalogação na Publicação

Serviço de Biblioteca e Documentação

Faculdade de Filosofia, Letras e Ciências Humanas da Universidade de São Paulo

A $447 \mathrm{~g}$

Almeida, Tiago Santos

Georges Canguilhem: combates pela história das ciências / Tiago Santos Almeida ; orientadora Sara Albieri. - São Paulo, 2016.

$220 \mathrm{f}$.

Tese (Doutorado)- Faculdade de Filosofia, Letras e Ciências Humanas da Universidade de São Paulo. Departamento de História. Área de concentração: História Social.

1. Georges Canguilhem. 2. Teoria da História e Historiografia das ciências. 3. Historiografia da medicina. 4. Epistemologia histórica. 5. História Intelectual. I. Albieri, Sara, orient. II. Título. 


\title{
RESUMO
}

Propomos uma investigação simultaneamente histórica e epistemológica dos trabalhos de Georges Canguilhem, buscando alargar e aprofundar nossa compreensão dos critérios que determinam tanto a escolha dos objetos, quanto os métodos de investigação e regras para a escrita da história das ciências. Essa investigação é reforçada por uma reconstrução dos debates intelectuais nos quais Canguilhem esteve envolvido ao longo da sua carreira acadêmica, debates que conduziram a verdadeiras reviravoltas na elaboração do seu pensamento. Assim, essa pesquisa trata da formação acidentada de um pensamento e de uma obra preocupada com a elaboração de uma teoria da História das Ciências a partir da superação da falsa dicotomia entre internalismo e externalismo.

\begin{abstract}
We propose a simultaneously historical and epistemological exploration of Georges Canguilhem's work, seeking to broaden and deepen our understanding of the criteria that determine both how objects of study are chosen, and how the investigative methods and rules for writing the history of the sciences are defined. This exploration is further supported by a reconstruction of the intellectual debates in which Canguilhem became involved over the course of his academic career, leading to various twists and turns in his thought. Hence the project involves an inquiry into the eventful formation of a body of thought of key importance to the general theory of the History of Science, seeking to move beyond the dichotomy between internalism and externalism.
\end{abstract}


Para Erivaldo e Suzel Almeida, meus pais. 
Não estamos alegres, é certo, Mas também por que razão haveríamos de ficar tristes?

O mar da história é agitado.

As ameaças e as guerras, haveremos de atravessá-las,

Rompê-las ao meio, Cortando-as como uma quilha corta as ondas.

(“E então, que quereis?”, Vladimir Maiakóvski) 


\section{AGRADECIMENTOS}

À Profa. Sara Albieri. Pela acolhida no Programa de Pós-Graduação em História Social da USP, pelo incentivo, pela confiança e pelo cuidado. Pelo respeito em relação às questões que mais me motivam como historiador e por todos os esforços para garantir que eu tivesse condições de persegui-las, até o outro lado do Oceano.

Ao Prof. Jean-François Braunstein, que deu ouvidos a essas questões de historiador e lhes garantiu cidadania no Centre de philosophie contemporaine da Sorbonne.

A Victor Wladimir, Kleverton Bacelar Santana, Maurício de Carvalho Ramos, Daniel Oliveira e Marcos Camolezi, com quem pude compartilhar minhas inquietações e descobertas, a quem tantas vezes recorri em busca de iluminação.

Aos professores, colegas e interlocutores que encontrei ao longo desses anos.

A Cleiton Camargo, meu irmão.

Aos amigos feitos através dos livros e das lutas.

À minha família, por todo o amor.

A Francine Iegelski, por me deixar fazer parte da sua vida.

À FAPESP - Fundação de Amparo à Pesquisa do Estado de São Paulo, pela bolsa de doutorado e pela bolsa de estágio no exterior. 


\section{Capítulo 1}

Retratos de Georges Canguilhem

A fagocitose althusseriana 28

Um historiador das racionalidades 41

\section{Capítulo 2}

História das ideias e história dos conceitos

Sigerist na França $\quad 64$

A história das ideias em 1943

A cultura cientifica 82

A história dos conceitos $\quad 92$

Capítulo 3

$\begin{array}{lr}O \text { social por toda parte } & 101\end{array}$

O estatuto social da ciência 113

$\begin{array}{ll}\text { As ideologias cientificas } & 118\end{array}$

Capítulo 4

Existe uma escola francesa de história da medicina?

O que é uma ideologia médica? 146

A vida e as normas $\quad 156$

A normalização e o conceito de biopoder em Michel Foucault 161

$\begin{array}{ll}\text { Consideração sobre a historiografia brasileira da medicina } & 167\end{array}$

\section{Capítulo 5}

Epistemologia histórica e história epistemológica 176

A historicização da epistemologia: Bachelard, Fleck e Canguilhem 177

$\begin{array}{ll}\text { Objetividade e historicidade do pensamento cientifico } & 190\end{array}$

$\begin{array}{ll}\grave{A} \text { guisa de conclusão } & 202\end{array}$

$\begin{array}{lr}\text { Referências bibliográficas } & \mathbf{2 0 7}\end{array}$

$\begin{array}{lr}\text { ANEXO } & 216\end{array}$ 


\section{Introdução}

Os historiadores sabem bem de onde vem a inspiração para o título dessa tese. Todos conhecem o livro de Lucien Febvre, o clássico Combats pour l'histoire: vers une autre histoire, de 1953. Este livro, como todo bom livro, tem também uma boa história. O que nos interessa aqui é a parte dessa história que nos ajuda a compreender melhor as relações entre os historiadores ligados ao projeto da revista dos Annales desde seus primórdios e os historiadores das ciências. A conclusão do livro Combats pour l'histoire tem por título "Vers une autre histoire", rumo a uma outra história, texto que Febvre publicou originalmente em 1949 na Revue de métaphysique et de morale, que consagrou um número (julho-outubro) aos "Problemas da história". Além de Febvre, publicaram textos naquele número especial da Revue autores como Claude Lévi-Strauss, Henri-Irénée Marrou, D. Parodi, Paul Ricœur, Tran Duc Tao, G. Darvy e Raymond Aron.

François Hartog considerou que aquele texto de Febvre, escrito em 1949 e publicado como conclusão de seu livro programático de 1953, tinha também a intenção de ser um tipo de testamento: queria estabelecer a herança e o herdeiro do projeto dos Annales. "Vers une autre histoire" começa com uma apresentação do livro inacabado de Marc Bloch, Apologie pour l'Histoire (1944), para depois chegar a Fernand Braudel, representante da continuidade do projeto que entendia ser a nova história. ${ }^{1}$ Dessa maneira, Febvre defendeu a "nova ciência histórica" se delimitando do domínio filosófico, afirmando-se como um "prático" da história. É como se a filosofia fosse um domínio diferente daquele próprio à reflexão histórica.

Nessa época, a história das ciências ainda era uma disciplina filosófica e a própria Revue de Métaphysique et Morale publicou diversos artigos de autores como Henry Berr, Gaston Bachelard, Alexandre Koyré ou Hélène Metzger que, em suas respectivas áreas de especialização, trabalharam coletivamente para a consolidação do programa desenvolvido no Centre International de Synthèse: a inserção das ciências na história, como parte da vida espiritual da civilização. Tal inserção, porém, era buscada pelas vias do racionalismo, quer dizer, tratava-se de mostrar como o pensamento científico se relacionava com aquilo que Abel Rey, então diretor do Institut d'Histoire des sciences et des techniques, chamava de "funções da consciência”. Dessa maneira, a historicização das ciências, na primeira metade do século

\footnotetext{
${ }^{1}$ Hartog avalia que o "adeus de Febvre a Marc Bloch é também uma saudação endereçada a Braudel, e o artigo vale como transmissão do bastão". HARTOG, "O olhar distanciado. Lévi-Strauss e a história", trad. Temístocles Cezar, Topoi, [vol.] 7, 12 (2006): 12 (9-24).
} 
XX, não era, a bem dizer, uma tarefa de historiadores, ao menos não daqueles que se interessavam pela nova história, pela história do social, tal como desenharam os precursores da revista dos Annales: Bloch, Febvre, Braudel. Assim, como parte mesmo do seu projeto historiográfico, deixaram de fora a história do pensamento científico e as ciências (embora reservassem algum interesse pela técnica), entregues em bandeja de ouro aos filósofos. Os combates pela história, assim, se não eram travados contra a história das ciências, certamente não se importavam com a sua sorte.

$\mathrm{Na}$ virada da primeira para segunda metade daquele século, marcada, retrospectivamente, pela ausência de diálogo entre essas duas vertentes históricas, a dos filósofos e a dos historiadores, Georges Canguilhem apareceu como uma exceção. Tendo conhecido, ainda no início da sua carreira universitária, os trabalhos daqueles que viriam a fundar a revista dos Annales, buscou uma aproximação com os responsáveis por aquela "revolução" na historiografia. Claude Debru, assistente de Canguilhem, nos disse, em entrevista concedida durante a elaboração dessa tese, que Canguilhem tentou durante anos convencer Braudel e seus colegas a se interessarem pela história das ciências. Conviveu durante anos com a recusa, sob o argumento de que a história das ciências não era para historiadores.

Mas existe também uma outra referência, essa menos evidente, para o título dessa tese. Trata-se do texto "Combats pour l'histoire des sciences: lettre ouverte aux historiens de mentalités" escrito por Yvette Conry. O texto foi publicado em 1983 pela Revue de synthèse, que organizou um número especial sobre a "História das ciências e mentalidades". Nomes como Jacques Roger, Roger Chartier, Pietro Redondi, André Burguière, Guy Beaujouan, Jacques Léonard e Jacques Le Goff publicaram seus textos naquele número da Revue. Não deixa de ser curioso o fato de que os historiadores engajados desde os anos 1970 na chamada história das mentalidades tenham participado deste debate sobre a história das ciências. Ainda mais se levarmos em consideração que alguns anos antes, logo na apresentação do dicionário La Nouvelle histoire, de 1978, dirigido por Jacques Le Goff, Roger Chartier e Jacques Revel, Le Goff deixou clara as diretrizes teóricas que mobilizavam essa "nova história", inclusive a história das mentalidades: todos escreviam a partir do legado de Braudel. Isto é, o predomínio do social e a noção de longa duração serviam de mote para a história.

O texto de Conry, discípula de Canguilhem, parece ter apreendido esse contexto de ideias. A autora chama por uma mudança na compreensão de ciência que tinham os historiadores das mentalidades e, por conseguinte, uma mudança na compreensão da tarefa da própria história das ciências: 
Essa carta aberta aos historiadores das mentalidades é, então, pela defesa e ilustração do pensamento científico na e por sua história: aqui não se trata $\mathrm{d} a$ ciência, numa visão cartesiana, metafísica e perimida, mas das ciências, e mais ainda do direito delas falarem por si mesmas, de suas capacidades de criarem seus conceitos, de sua aptidão por decidirem historicamente sobre a racionalidade e sobre a verdade, e, em último registro, de seus direitos de modificar nossas "mentalidades". A essa tarefa de um racionalismo aberto, nos parece que os historiadores das mentalidades podem dar ouvidos aos historiadores das ciências. ${ }^{2}$

Não é difícil chegar à conclusão de que os historiadores das mentalidades se mantiveram surdos ao apelo de Conry para que se engajassem na escrita de uma história das ciências como um racionalismo aberto. Os historiadores franceses optaram por se manter afastados da história das ciências, não entendiam como sua a tarefa de escrever a história das ciências enquanto diferentes formas do projeto racional de busca pela verdade, mesmo que se entenda que a própria ideia de verdade muda na e pela história. Para eles, demasiadamente abstrato e filosoficamente ideológico, esse tipo de problema parecia muito afastado do que realmente interessava: o domínio do social, lugar em que se poderia apreender a história e a mudança em todas as suas dimensões, em todas as suas repercussões para a vida dos homens.

Em outra entrevista realizada durante a elaboração dessa tese, questionamos o filósofo e historiador do pensamento médico Jean-François Braunstein sobre a situação de indigência da história da medicina na França, que contrasta com a grandeza de nomes como o de Canguilhem e Michel Foucault. Para Braunstein, “desde Daremberg [1817-1872], a história da medicina está morta na França". Ele explica:

Com Daremberg, vemos a ideia de que não é preciso fazer filosofia, não é preciso refletir: é preciso apenas estabelecer os textos. Então, a ideia de uma história social da medicina como havia nos Estados Unidos e por toda a parte no mundo desaparece completamente na França, por diversas razões que se ligam, na minha opinião, ao ensino universitário da medicina. Nunca tivemos departamentos de história da medicina. Os primeiros historiadores reúnem-se acerca da Escola dos Annales. Há alguns historiadores do corpo e da saúde, mas não são historiadores da medicina. Os historiadores das mentalidades não se interessam evidentemente pela medicina; eles vão se interessar preferencialmente pela água, pelo banho, pelos curativos, pela dor. Há trabalhos muito interessantes de Jean-Pierre Peter ou de Georges Vigarello, por exemplo. Mas a história da medicina é demasiado "científica"

\footnotetext{
${ }^{2}$ CONRY, "Combats pour l'histoire des sciences: lettre ouverte aux historiens de mentalités", p. 406.
} 
para interessá-los. ${ }^{3}$

Michel Foucault, em um texto de 1984, tem uma avaliação certeira sobre a prevalência do social para os historiadores: "desde o fim do século XIX até cerca de 1960, a sociedade se tornou o objeto fundamental da história. Tudo o que não pudesse ser considerado como análise de uma sociedade não seria história"4. É por isso, acrescentou, que "os Annales jamais falaram de historiadores franceses das ciências como Bachelard e Canguilhem, ao menos antes de 1970". Se não se pode enquadrar a história das ciências na história social, então a história das ciências não é história. Assim, observou, para os historiadores dos Annales "a história do recrutamento da população médica é história, mas as transformações mesmo do conceito de normal, não". O que talvez tenha escapado aos historiadores do social não escapou a Foucault: "as transformações que ocorreram sobre as práticas médicas tiveram sobre a saúde das populações efeitos não negligenciáveis" e, por essa razão, seria preciso se lembrar de Max Weber, para quem "a racionalidade não é apenas o produto de uma sociedade, mas um fator constitutivo da história dos homens".

Foucault, tendo sido aluno de Canguilhem, sabia bem que fazer uma história das ciências significava tratar de um problema que era ao mesmo tempo de ordem racional e social. Sim, pois o historiador das ciências, para Canguilhem, precisaria se lançar na tarefa de apreender o processo de transformação epistemológica que resultou na constituição de cada ciência, em determinado tempo e lugar. Dito de outro modo, para Canguilhem, o dado social não seria contraditório com a investigação epistemológica, mas também não deveria fazer com que o historiador abrisse mão de entender aquilo que faz da ciência uma ciência: a busca pela verdade.

Desse modo, para Canguilhem, historicizar uma ciência não equivaleria a relativizá-la. Os recentes trabalhos de Lorraine Daston sobre a história da objetividade parecem reverberar esse princípio canguilhemiano. Ao estudar as ciências em seu desenvolvimento histórico, Daston quer entender menos a história de uma ciência específica e mais as ideias sobre o conhecimento que articulam os discursos de determinada ciência. Daston e seus colegas do Instituto Max Planck para a História das Ciências, em Berlim, estudam os conceitos epistemológicos que evoluem e mudam (como "observação" ou "experiência") e os valores epistêmicos (como objetividade e imparcialidade) que desempenham certos papéis na reflexão

\footnotetext{
${ }^{3}$ ALMEIDA e CAMOLEZI, "Entrevista com Jean-François Braunstein”, p. 166.

${ }^{4}$ Foucault, "Le souci de la vérité", 1473.
} 
sobre o conhecimento e a crença. Ela nos parece ser interessante aqui justamente porque propõe historicizar a ideia de objetividade, isto é, mostrar que seus critérios são culturalmente definidos, mas não conclui, a partir daí, que escrever essa história signifique desacreditar essa ciência. Ao contrário, é por se constituir também socialmente e estar, portanto, sujeita às transformações dos seus critérios de racionalidade, que tal ou tal prática ou teoria seriam reconhecidas como objetivamente válidas.

Se formos para o campo específico da história da medicina este problema da relação entre o racional e o social será ainda mais evidente. De fato, uma das tensões que marcaram os debates historiográficos no último século é a situação da história da medicina como um domínio especializado da história das ciências, mais especificamente das ciências da vida, ou como uma disciplina inteiramente diferente, devido à função social que a medicina, enquanto técnica do ser vivo, foi chamada a desempenhar nas sociedades contemporâneas. Claire Salomon-Bayet, em "Histoire des sciences et histoire de la médecine", falou sobre essa diversidade:

\begin{abstract}
História da medicina, história das ciências médicas, história das ciências biológicas, história das ciências biomédicas, expressões que dão o ritmo para uma história de dois séculos, que retraçam a evolução de uma profissão fundada sobre uma competência técnica, a qual se acrescenta e, às vezes, se substitui uma competência científica; sobre a qual se chocam competências vindas de fora, um "de fora" que é tanto disciplinar quanto profissional. O historiador está, então, necessariamente confrontado à análise dos diferentes discursos, tomados de comunidades diferentes, em lugares diferentes, confrontados a momentos de intensas confrontações entre disciplinas ${ }^{5}$.
\end{abstract}

Nos anos 70, a nova história social da medicina tomou forma como uma reivindicação de identidade autônoma dos historiadores de ofício num movimento também marcado pela afirmação daquilo que ela não seria: a bem estabelecida história burocrática da medicina, escrita por médicos para outros médicos, consagrada à celebração dos grandes doutores e suas conquistas, whiggista e triunfalista, orgulhosamente erudita e ingenuamente positivista. Mas não seria apenas a história "comemorativa" que seria atacada. A obra de Canguilhem passou a ser vista como ultrapassada e ideologicamente condenada por aderir a uma visão extremamente "cientificista" ou, seu sinônimo, "conceitual", da prática médica. Confundiu-se o interesse de Canguilhem pela medicina científica com um interesse pelo que nela haveria de exclusivamente científico.

\footnotetext{
${ }^{5}$ SALOMON-BAYET, "Histoire des sciences et histoire de la médecine", p.54.
} 
É interessante notar a coincidência de perspectivas da "nova história social" da medicina e da "história social das diferentes práticas culturais" defendida pelos historiadores ligados ao projeto dos Annales a partir de meados dos anos 1980. Em 1989, surge uma nova configuração da revista dos Annales, uma quarta geração assume a revista, na defesa do estudo histórico das práticas culturais. Ponto de vista animado especialmente por Roger Chartier e Alain Boureau. O conceito de práticas sociais diferenciadas remete à materialidade dos processos culturais e, por conseguinte, aos fundamentos sociais e econômicos dessas práticas, assim como aos espaços e aos modos concretos de construção de mensagens e ideias e dos mecanismos e figuras de sua distribuição, de apropriação e assimilação. Essa história social das práticas sociais opera, então, um distanciamento crítico da concepção de cultura que vigorou nos anos 1960 e 1970, da qual história das mentalidades era, então, a referência.

No final do terceiro quarto do século XX o social invadiu a história da medicina. Esta invasão, durante um bom período, decretou a desvalorização da historiografia da medicina dita "tradicional". Frank Huisman e John Harley Warner, organizadores de Locating Medical History. The Stories and Their Meanings, de 2006, ironizam o fato de que os historiadores da medicina, tão desinteressados pela história da história da medicina, tenham um sentido histórico tão aguçado quando se trata de dizer que a história das relações das sociedades com as epidemias pode ajudar profissionais da saúde, instituições e mesmo Estados a melhor compreender e intervir em situações de doença generalizada, ou quando argumentam que a história da medicina é parte fundamental de uma formação humanística cada vez mais necessária aos médicos, num momento em que já se começa a falar de "morte da clínica". A história da medicina pode levar a uma melhor compreensão da relação da medicina com o doente, do interesse público pelas questões de saúde ou decisões éticas a respeito da doença e da morte, mas esse interesse histórico pelas práticas da medicina do passado, pelo modo como diferentes sociedades ou civilizações entendia a saúde e reagiam às doenças, não encontra, nos historiadores da medicina, interesse correspondente pelo passado da própria disciplina.

Em Locating Medical History, Huisman e Warner mostram como a avidez, o interesse pelo passado da "nova história social" da medicina, foi acompanhada pela condenação do passado da própria historiografia da medicina. Esta última, nesse novo projeto, se transformou num verdadeiro obstáculo às investigações da dimensão histórica do social na medicina:

Durante as muitas últimas décadas, a história médica "tradicional" foi mais que frequentemente apresentada como uma figura simplista e estreita, citada apenas quando podia ser trucidada. Autores que cada vez menos parecem ter lido os trabalhos dos primeiros anos desse campo atacam aquele trabalho a 
fim de aumentar a importância e a novidade de suas próprias contribuições. Tal postura historiográfica é uma estratégia retórica presente em virtualmente todos os campos da história. No entanto, permanece irônico o fato de que, enquanto historiadores da medicina, muitos de nós reflitam tão pouco sobre o passado de nossa própria empreitada enquanto moldamos e remoldamos nossa prática histórica. ${ }^{6}$

A redescoberta, ou revaloração que a obra de Canguilhem tem experimentado nas últimas duas décadas, tem a ver com uma outra compreensão, que julgamos melhor porque mais histórica, da dimensão do social para a história das ciências da vida e para a história da medicina. Nova compreensão que, acreditamos, está relacionada à abertura de seus arquivos pessoais e de trabalho aos pesquisadores. Graças a uma bolsa concedida pela FAPESP, essa tese se beneficiou de um período de pesquisa de doze meses em Paris, quando tivemos acesso aos arquivos Canguilhem, preservados no CAPHÉS - Centre d'Archives en Philosophie, Histoire et Édition des Sciences. Nesse centro de documentação estão preservadas milhares de páginas inéditas manuscritas, sobretudo notas de cursos inteiros durante mais de trinta anos de docência, que ajudaram a revelar aspectos originais do pensamento de Canguilhem. Embora sua obra também esteja sendo publicada pela Editora Vrin, até o momento apenas dois dos seis tomos previstos foram lançados e, ainda que reúnam centenas de textos inéditos ou considerados perdidos, eles apenas arranham a superfície da teoria canguilhemiana da história do pensamento médico. Além disso, segundo instruções de Canguilhem em seu testamento, e vontade respeitada pelos seus herdeiros, os manuscritos preservados no CAPHÉS, que enriquecem e esclarecem sensivelmente os textos, não podem ser publicados, fotografados ou fotocopiados. Assim, o levantamento das fontes relevantes para a nossa pesquisa foi seguido de um minucioso trabalho de transcrição desses documentos. Nessa tese, embora façamos amplo uso daqueles manuscritos, tivemos sempre o cuidado de coloca-los a serviço de uma interpretação que se não pode ser deduzida da obra publicada ou em vias de publicação, pode ser nela verificada. Assim, evitamos a redação de um trabalho cujo grande mérito residiria na "descoberta" de fontes acessíveis a poucos.

E um dos aspectos que conseguimos ressaltar no pensamento de Canguilhem a partir do equilíbrio entre o publicado e o manuscrito, e que pode ser a nossa principal colaboração para sua fortuna crítica, diz respeito às relações que Canguilhem estabeleceu entre ciência e não-ciência. Canguilhem nunca advogou uma história das ciências que teria como seu objeto final uma razão descolada da história concreta das ciências. Contudo, a história das ciências

\footnotetext{
${ }^{6}$ Frank Huisman e John Harley Warner, Locating Medical History. The Stories and Their Meanings p. 2.
} 
não é uma história como todas as outras. Ela deve ser escrita a partir de um senso de verdade. Nos anos 1960, Canguilhem escandalizou pelo modo como afirmou a verdade como um produto exclusivo das ciências, negado até mesmo à filosofia, sem por isso ignorar as relações que as ciências mantêm com a não-ciência. Sua preocupação, afinal, era precisamente saber como continuar a se dizer racionalista, quer dizer, sustentar a ideia de que não existe verdade que não seja científica, ao mesmo tempo em que concedia um estatuto positivo à não-ciência. Essa chocante ideia de Canguilhem, qual seja, a de que "não existe verdade que não seja científica", é, muito provavelmente, a principal característica da epistemologia histórica. Ela foi apresentada em 1964, numa emissão televisiva escolar sobre o tema "Filosofia e Ciência". Nessa emissão, logo publicada, Alain Badiou faz uma série de perguntas a Canguilhem, sendo essas as mais contundentes:

Badiou: Devemos continuar opondo radicalmente o conhecimento científico ao conhecimento vulgar?

Canguilhem: Sim, e cada vez mais. Não existe conhecimento específico sem, por um lado, teorias matemáticas bem elaboradas, e, por outro lado, sem o manejo de instrumentos cada vez mais complexos. Eu diria mesmo que não existe conhecimento vulgar.

Badiou: Com isso você quer dizer que entende a expressão "conhecimento científico" como um pleonasmo?

Canguilhem: Você me entendeu perfeitamente. É isso o que eu quero dizer. Um conhecimento que não seja científico não é um conhecimento. Eu afirmaria que "conhecimento verdadeiro" é um pleonasmo; que "conhecimento científico" também; que "ciência e verdade" também; e que tudo isso é a mesma coisa. Isso não quer dizer que não exista, para o espírito humano, nenhuma meta ou nenhum valor fora da verdade, mas significa que você não pode chamar de conhecimento aquilo que não é, e que não pode dar esse nome a algum modo de viver que não tenha nada a ver com a verdade, isto é, com o rigor.

Quando apresentou o conceito de ideologia científica nos anos 1970, Canguilhem nos lembrou de algo que escapou aos historiadores e que está na base da dificuldade que os Annales encontraram em sua tentativa de historicização das ciências. A relação entre ciência e não-ciência é "evidentemente mais que um problema de técnica ou de método histórico acerca do passado do conhecimento científico, tal como ele pode ser reconstituído a partir dos documentos ou dos arquivos", afirma Canguilhem. Ela é "um problema epistemológico acerca do modo permanente de constituição dos conhecimentos científicos na história”. Assim, mais do que a história do dizer a verdade, Canguilhem se preocupou com a história do

\footnotetext{
${ }^{7}$ CANGUILHEM, “Qu'est-ce qu'une idéologie scientifique?”, p. 34.
} 
estar na verdade. Mais do que os gloriosos avanços da ciência, foi a preocupação com as condições, conceituais e históricas, de possibilidade dos problemas científicos que caracterizou a sua obra. A abertura para o social só foi possível porque naquele período de transformações na historiografia, Canguilhem manteve os olhos abertos diante do espetáculo da "descontinuidade em história da história", considerando as contribuições trazidas por diferentes autores, de diferentes tradições filosóficas e historiográficas, da Alemanha aos Estados Unidos, passando pela Inglaterra. É por isso que, nesse ensaio de história intelectual, adotamos aquilo que Salomon-Bayet chamou de regra da anamorfose: "interferência de uma época sobre a outra, de uma disciplina sobre a outra, de uma tradição nacional sobre a outra".

Não obstante a grandeza dessa obra e da relevância de Canguilhem para a formação do cenário filosófico francês na segunda metade do século XX, Canguilhem nunca penetrou o inconsciente historiográfico dos historiadores - ao menos não diretamente, pois há que se considerar o peso de alguns dos seus alunos que compartilhavam com ele certos axiomas metodológicos, como Michel Foucault e Dominique Lecourt mas também François Delaporte e Claire Salomon-Bayet, para mencionarmos alguns dos nomes mais conhecidos dos historiadores brasileiros. Sendo assim, achamos que esse novo momento da história da recepção do pensamento de Canguilhem na historiografia pode ser melhor compreendido se levarmos em conta o quadro geral das preocupações que marcaram as ciências humanas e sociais nas duas últimas décadas do século XX. O historiador François Hartog chama esse momento de "tentação da epistemologia", quando historiadores, mas também cientistas políticos, sociólogos e antropólogos passam a questionar seu ofício não apenas do ponto de vista metodológico, mas também pelas perguntas fundamentais acerca dos pressupostos teóricos que sustentam seus discursos. Esses investigadores retomaram o questionamento sobre quais são os critérios que marcam a correção das análises científicas, quais são os valores que sustentam as preocupações dos autores, o que está em jogo para eles e seus pares quanto escrevem e que revelam o significado mais substantivo dos textos. Vê-se que essa nova atitude intelectual, essa "tentação da epistemologia", pode ser entendida como uma virada crítica, a necessidade de pensar as regras que regem o campo ou disciplina em que cada investigador se localiza.

No caso da história, essa virada crítica, perceptível também a partir dos anos 1980, impulsionou a emergência de um novo domínio de reflexão dos historiadores sobre a própria história: a chamada historiografia. Jacques Revel, Roger Chartier, Gérard Noiriel e mesmo Hartog entenderam esse novo momento como um momento de crise, quando os historiadores passaram a colocar em dúvida a própria capacidade explicativa da história, a sua 
inteligibilidade. Assim, ao contrário do entusiasmo da crítica epistemológica que marcou a primeira metade do século XX pela ideia fundamental de revigorar e expor os critérios de racionalidade de cada disciplina, a virada reflexiva das décadas finais do século XX tem um tom mais contido, mais sóbrio, menos confiante nos discursos científicos em geral.

Os historiadores que passaram a se interessar pela prática historiográfica (a história que se volta para si mesma) foram cada vez mais atraídos pela história intelectual. Para Hartog, os historiadores teriam operado uma verdadeira aproximação entre esses dois termos (epistemologia e historiografia), "como se um chamasse o outro, completando, corrigindo, ou nuançando seus conteúdos e contornos" ${ }^{\prime 8}$. Os termos epistemologia e historiografia passaram, então, a ser associados pelos historiadores como se eles quisessem realizar uma espécie de conjunção, visando "não uma epistemologia dura (muito distante), ou simplesmente uma história da historiografia (muito internalista), mas uma abordagem atenta aos conceitos e aos contextos, às noções e circunstâncias" da escrita da história.

Para nós, a obra de Canguilhem, em particular o modo como propõe a articulação entre a razão e o social, entre a epistemologia e a história, traz uma perspectiva original para o debate já em curso na historiografia das ciências da vida e da medicina, mas não somente. A "virada reflexiva" na história poderia ser entendida, a partir dos problemas epistemológicos de Canguilhem, como sinal de maturidade da própria disciplina, capaz de tomar a si mesma como objeto. Afinal, em sua obra vemos o quão é fecundo e potente tratar racionalidade e historicidade como pares complementares e não excludentes.

No primeiro capítulo, mostramos como se construiu a imagem do "Georges Canguilhem, historiador das ciências", isto é, como um filósofo que nunca deixou de se reconhecer como tal e que diversas vezes recusou o rótulo de historiador, que tem uma vasta obra dedicada aos problemas filosóficos mais tradicionais nos campos da lógica, metafísica, política e pedagogia, teve seu nome irrevogavelmente associado a uma disciplina histórica. Problematizamos, a partir da abordagem da história intelectual, duas interpretações recentes que tentam livrar Canguilhem desse título ou dessa acusação, a depender da perspectiva: por um lado, a de Bruno Latour, para quem Canguilhem é um usurpador do título de historiador das ciências; por outro, a de Camille Limoges, profundo conhecedor da obra de Canguilhem,

\footnotetext{
${ }^{8}$ HARTOG, "La tentation de l'épistémologie", p.82.
} 
organizador dos seus arquivos e da publicação da sua obra completa, para quem seu antigo professor só pôde ser considerado um historiador das ciências devido ao desconhecimento, pela maioria dos seus comentadores, da real extensão da sua obra.

No segundo capítulo, mostramos que o interesse de Canguilhem pela história e pelos historiadores, ao contrário do que se imagina, aparece cedo em sua obra e pode ser detectado mesmo naqueles textos habitualmente classificados de "filosofia médica" ou "filosofia biológica". Basta, para isso, estar atento ao seu contexto intelectual de produção, no caso, a própria historiografia científica na passagem da primeira para a segunda metade do século passado. Mostramos que, ao longo da década de 40 até o ano de 1955, a partir da aproximação com a história das ideias, Canguilhem começou a elaborar uma técnica histórica própria para a investigação das ciências da vida e da medicina. Nesse percurso, mostramos que, longe de ser um historiador dos cataclismos científicos, Canguilhem também está preocupado com as permanências. Parece-nos que a história das ideias e a história dos conceitos, tal como apresentada por Canguilhem, é menos um projeto de demarcação de descontinuidades e mais um esforço de multiplicação das temporalidades (entre elas, a do tempo descontínuo).

No terceiro capítulo, mostramos como, a partir dos anos sessenta, através de encontros intelectuais aparentemente paradoxais, Canguilhem passou a se interessar pela relação entre a "razão" e o "social". Nesse capítulo, ganham destaque seus cursos, berço da reflexão sobre o estatuto social das ciências, sobre o papel da sociabilidade na determinação dos objetos científicos e na construção da verdade. É também nos seus cursos que Canguilhem elabora, a partir de exemplos precisos trabalhados ano a ano, uma de suas principais contribuições teóricas para a história das ciências, o conceito de ideologia científica. Esses elementos nos permitem uma reflexão sobre a natureza do objeto da história das ciências e também da sua relação com os objetos das ciências das quais se escreve a história.

No quarto capítulo, propomos uma investigação sobre a chamada "escola francesa de história da medicina", quer dizer, sobre a sua existência de fato e de direito. Para isso, exploramos a interpretação de Canguilhem sobre a função desempenhada pela medicina no interior das sociedades modernas e a busca dos meios teóricos e práticos para sua execução. Mostramos, que a "ideologia médica" não é um caso especial da "ideologia científica", mas um conceito de tipo diferente, que diz respeito às exigências políticas levadas a cabo por uma técnica dos seres vivos. Assim, parece-nos que o conceito de foucauldiano de biopoder é constituído no espaço histórico delimitado pelo programa social ao qual Canguilhem deu o nome de "normalização". Antes de concluir, fazemos algumas considerações sobre a historiografia da medicina no Brasil, não para esgotar assunto, mas para reforçar a tese de 
que, se não há "escola francesa", é perfeitamente possível falar de um "estilo francês de história da medicina".

Por fim, no quinto capítulo proponho uma investigação sobre a chamada “epistemologia histórica", buscando apreender o significado da sua recuperação nos Estados Unidos ou na Alemanha no momento mesmo em que ela é dada como aniquilada em solo francês. Essa investigação é também histórica, posto que recuperamos as contribuições de Bachelard, Fleck e Canguilhem para o processo conhecido como "historicização da epistemologia", que encontrou seu lugar na Europa, no início do século passado, e se caracteriza pela crítica da teoria do conhecimento através da história das ciências. Também aqui, parece-nos que, entre "epistemologia histórica" ou "história epistemológica", entre "escola francesa" ou "escola alemã", a opção pela noção de "estilo" contribui para que possamos melhor compreender e intervir nos debates contemporâneos sobre a teoria e a prática da história das ciências. 


\section{Capítulo 1 \\ Retratos de Georges Canguilhem}

Entre 1955 e 1971, Canguilhem foi professor de história e filosofia das ciências na Sorbonne e diretor do Institut d'histoire des sciences et des techniques (hoje, Institut d'histoire et philosophie des sciences), ocupando a cadeira que pertencia a Gaston Bachelard e, antes dele, a Abel Rey, o fundador do instituto que durante muito tempo foi o único do gênero na França. Nesses dezesseis anos, além de oferecer diversos cursos dedicados à história das ciências, Canguilhem publicou sua segunda tese doutoral, La formation du concept de réflexe au XVII et XVIII siècles, orientada por Gaston Bachelard; relançou sua primeira tese, de 1943, que, acrescida de novas reflexões, foi intitulada Le normal et le pathologique; reeditou uma versão ampliada da tese complementar $O$ conhecimento da vida; apresentou conferências e escreveu dezenas de artigos dedicados à história das ciências da vida e da medicina, a maioria reunida nos livros Études d'histoire et de philosophie des sciences, Idéologie et rationalité dans l'histoire des sciences de la vie e no póstumo Écrits sur la médecine ${ }^{1}$. Em 1970, Canguilhem dirigiu os dois volumes da obra coletiva Introduction à l'Histoire des Sciences, que reuniu alguns dos principais historiadores das ciências franceses e ficou conhecida como o "vade mecum do pequeno historiador das ciências", uma importante contribuição ao projeto de promoção da história das ciências a disciplina de primeiro escalão no ensino universitário francês. Em 1983, Canguilhem recebeu a "Medalha George Sarton", mais prestigiosa honraria da área de história das ciências, concedida pela History of Science Society em reconhecimento a uma vida de conquistas acadêmicas. E, ainda assim, não é evidente que possamos falar de Canguilhem como um historiador das ciências. E também não é evidente porque decidimos falar sobre a historicização das ciências na obra de Canguilhem em uma tese de doutorado defendida junto ao Departamento de História da Universidade de São Paulo.

A situação é, no mínimo, ambígua. É verdade que, para a realização dessa pesquisa, nos apoiamos em autores brasileiros que demonstram uma leitura rigorosa dos textos de Canguilhem. Também não podemos dizer que, no Brasil, Canguilhem continue a ser lembrado apenas por ter sido o mestre de Michel Foucault e o discípulo de Gaston Bachelard.

\footnotetext{
${ }^{1}$ Sempre que possível, faremos referência ao título das traduções brasileiras dos livros de Canguilhem. Quando detectamos problemas com a tradução optamos por propor uma tradução própria e, nesses casos, a referência será feita ao texto original em francês.
} 
Entre nós, sua principal obra, O normal e o patológico, é bastante conhecida nas faculdades de medicina e de saúde pública, onde obteve uma prestigiosa reputação desde os anos 70. Mas foi apenas recentemente que vimos serem traduzidos os livros $O$ conhecimento da vida e os Estudos de história e de filosofia das ciências concernentes aos vivos e à vida. O interesse renovado pelos textos de Canguilhem, motivado pela descoberta de textos inéditos e pela publicação das suas obras completas na França, também é verificado entre os pesquisadores brasileiros, fato que medimos pelo aumento de pesquisas de pós-graduação, livros, artigos e mesmo eventos dedicados ao seu pensamento. Mas tudo isso acontece num momento de acirramento do debate historiográfico, cujo objetivo parece ser o estabelecimento de uma orientação hegemônica para a prática da história das ciências. E a realização desse projeto exige a interdição da leitura de Canguilhem - uma exigência que vem de fora, da própria França.

Bruno Latour afirmou, repetidas vezes, que Gaston Bachelard e seus discípulos epistemólogos (e nos textos de Latour, Canguilhem não passa de um mero discípulo de Bachelard, com poucas ideias próprias) elevaram a "nível de princípio fundador" a assimetria entre as verdadeiras ciências e as falsas: “Apenas estas últimas - as ciências 'proscritas' podem estar ligadas ao contexto social. Quanto às ciências 'sancionadas', apenas se tornam científicas porque se separam de qualquer contexto, qualquer traço de contaminação, qualquer evidência primeira", acusou ${ }^{2}$. Para Latour, se Canguilhem se interessou pelas ideologias e pela história geral, foi para fazer brilhar mais forte a verdade, para mostrar como a ciência deixou para trás tudo aquilo que não passava, primeiro, de obstáculo e, em seguida, de erro. É a assimetria entre verdade e erro, entre ciência e ideologia, Latour argumenta, que funda a epistemologia de Bachelard, necessariamente descontínua, e cujo corolário seria uma história das ciências a-histórica - aquela de Canguilhem. Os objetos que passaram pelas mãos do epistemólogo Canguilhem, afirma Latour, tiveram suas raízes arrancadas, até sobrar apenas "o objeto extraído de toda a rede que lhe dava sentido". Finalmente, para Latour, Canguilhem é, na verdade, um "usurpador do rótulo de historiador das ciências", pois seu interesse é pela ciência que "escapou de seu próprio passado".

Anunciado por David Bloor em 1976, no livro Knowledge and social imagery, o princípio de simetria (ou "primeiro princípio de simetria", como se refere Latour, que entrou em polêmica com Bloor) é um dos quatro pontos principais do chamado "programa forte" da sociologia do conhecimento. Para investigar o conteúdo e a natureza do conhecimento

\footnotetext{
${ }^{2}$ LATOUR, Jamais fomos modernos, p. 92.
} 
científico, escreveu Bloor, a sociologia do conhecimento deveria ser simétrica em seu "estilo de explicação", ou seja, "os mesmos tipos de causa explicariam, digamos, crenças verdadeiras e falsas"3. Esse princípio, na opinião de Latour, abalou os estudos sobre as ciências e as técnicas ao restabelecer a continuidade, a historicidade e a justiça, supostamente negadas por Canguilhem, à história das ciências. "Bloor é o anti-Canguilhem", sentencia 4 .

Latour ainda escreveu que a impossibilidade, pela epistemologia francesa, de problematizar o estatuto da cientificidade das ciências não ficou restrita aos discípulos diretos de Bachelard. Mesmo os Annales teriam adotado essa perspectiva, razão pela qual historicizaram as lágrimas, os odores, a morte, enfim, tudo, menos as ciências. Já que os Annales, segundo Latour, reclamavam a cientificidade dos seus métodos (embora negassem ter pretendido transformar a história em ciência), especialmente dos quantitativos, não podiam questionar o status das ciências, pois isso significaria questionar sua própria legitimidade. Para Latour, aos olhos dos historiadores ligados aos Annales, a ciência, sendo inexoravelmente aquilo que é, exige um estatuto diferente para história das ciências, razão pela qual nunca ousaram fazê-la. Seria imperativo que a história das ciências não ameaçasse a validade universal das ciências para não correr o risco de relativizar a própria cientificidade dos instrumentos e técnicas dos novos historiadores. Assim, para Latour, embora os Annales até pudessem, muito timidamente, reconhecer algum mérito na história da constituição local desse projeto universal chamado ciência, jamais iriam tão longe a ponto de investigar como se constituiu um mundo em que a ciência é reconhecida como universalmente válida. "Por isso Canguilhem parece, para Le Goff, ser um historiador das ciências ideal: ele trabalhou na interface da epistemologia, da filosofia e da história."

Mais recentemente, insistindo sobre os riscos de continuar concedendo a Canguilhem o rótulo de historiador das ciências, Latour tentou fazer do médico e epistemólogo polonês Ludwik Fleck o precursor (Jean-François Braunstein diria “o fundador mítico") da sociologia do conhecimento. Afirmou ter encontrado no livro Gênese e desenvolvimento de um fato científico, de 1935, os traços principais do "programa forte", quarenta anos antes de Bloor. Segundo Latour, é possível identificar tanto em Fleck quanto em autores como Bloor, Barry Barnes, Harry Collins e Steve Shapin uma "atenção à prática - inclusive à prática teórica - em vez da ligação dos conceitos entre si”; "o interesse pela ciência em vias de se fazer, por

\footnotetext{
${ }^{3}$ BLOOR, Knowledge and social imagery, p. 5-6.

${ }^{4}$ LATOUR, Jamais fomos modernos, p. 93.

${ }^{5}$ BOWKER e LATOUR, "A booming discipline short of discipline: (Social) Studies of Science in France", p. 719-721, passim. Conforme nota no texto original, a opinião de Le Goff sobre Canguilhem teria sido manifestada em entrevista concedida a Latour.
} 
oposição aos saberes ensinados"; "a recusa do ponto de vista retrospectivo que força sempre a ridicularizar os antigos sistemas de pensamento" etc. Mesmo o princípio de simetria, segundo Latour, aparece no livro de Fleck, sob o nome de "método comparativo". Bastou para que Latour alarmasse uma oposição radical entre Canguilhem e Fleck:

Para os leitores franceses, habituados à epistemologia de Bachelard e Canguilhem, cujo trabalho inteiro consiste em extrair a racionalidade escondida nos meandros da história social das ciências para melhor fazer se destacar a diferença total entre o racional e o irracional, entre a ciência e a ideologia, Fleck parece ter os mesmos defeitos que essa explicação social das ciências que eles tanto combateram. Que ele seja o precursor dessa aberração relativista é algo que só podemos acrescentar aos seus defeitos: realmente, não há do que se gabar em tê-la inventado... ${ }^{6}$

A apreciação deliberadamente errada da epistemologia francesa para fazer o elogio de Fleck não passou despercebida pelos comentadores de Canguilhem. Como escreveu um espantado Jacques Bouveresse no prefácio ao primeiro tomo das Euvres Complètes de Canguilhem, afirmações como as da citação acima - estrategicamente publicadas no posfácio à tradução francesa daquele livro de Fleck - "fazem cair de sobressalto mesmo um leitor um pouco superficial das obras de Canguilhem".

Paradoxalmente, a leitura escrupulosa dos textos de Canguilhem também permite problematizar o rótulo de historiador que lhe foi atribuído e que, é preciso dizer, ele mesmo nunca reivindicou. Em 1972, a revista Tonus publicou uma entrevista concedida por Canguilhem a François Proust. A entrevista, que esteve "perdida" durante muito tempo ${ }^{8}$, começa da seguinte maneira: "Professor Canguilhem, o que é a história das ciências?". A questão apenas parece abrupta; mas o momento não poderia ser mais oportuno. Esse é um dos últimos documentos com o imprimatur de Canguilhem antes da sua aposentadoria do cargo de professor de história e filosofia das ciências que ocupava na Sorbonne. "Eu não sou verdadeiramente um historiador das ciências", respondeu. "Sou um professor de filosofia que se interessa por um certo número de questões, que são as relações entre a filosofia e a ciência e em particular aquelas sobre a fabricação, o nascimento, a importação e a exportação de um

\footnotetext{
${ }^{6}$ LATOUR, “Transmettre la syphilis - partager l'objectivité", p. 99.

${ }^{7}$ BOUVERESSE, "Préface aux Euvres Complètes de Georges Canguilhem”, p. 40.

${ }^{8}$ Agradeço ao Prof. Camille Limoges, por ter me indicado a localização exata do documento, que ainda não havia sido catalogado pelo CAPHÉS à época das minhas pesquisas. Foi o Prof. Limoges quem anunciou a redescoberta dessa entrevista, "esquecida ou passada despercebida, provavelmente porque publicada numa revista profissional para médicos raramente frequentada por filósofos e historiadores" (LIMOGES, "L'épistémologie historique dans l'itinéraire intellectuel de Georges Canguilhem”, p. 65).
} 
certo número de conceitos interpretativos de funções biológicas"”. Ora, todos os cursos ministrados pelo filósofo Canguilhem naqueles dezesseis anos na Sorbonne foram dedicados à história do pensamento científico. Encontraremos outros exemplos daquela curiosa preocupação em se delimitar dos historiadores das ciências enquanto afirma se interessar por questões cujo lugar teórico de elaboração e resolução é a história das ciências. Mas são documentos como esses, encontrados em meio aos arquivos pessoais de Canguilhem, que tem reforçado certa releitura da sua obra.

Foram as primeiras apresentações gerais do pensamento de Canguilhem, publicadas por Pierre Macherey em 1964 e por Dominique Lecourt em 1971, além daquela ainda mais famosa publicada por Michel Foucault em 1978, que consolidaram, inclusive fora da França, a imagem do "historiador das ciências". O texto de Lecourt, "La historia epistemologica de Georges Canguilhem", e o texto de Foucault, "Introduction by Michel Foucault", foram escritos para servir de prefácio às traduções argentina e estadunidense de $O$ normal $e$ o patológico, principal livro de Canguilhem. Já o texto de Macherey, "La philosophie de la science de Georges Canguilhem. Épistémologie et histoire des sciences”, inicialmente publicado na revista La Pensée com uma apresentação de Louis Althusser que lhe rendeu grande visibilidade, vem sendo usado, desde 1982, como posfácio da tradução brasileira daquele livro. E não é apenas o sucesso que $O$ normal e o patológico conheceu a partir dos anos 70 que está diretamente associado àqueles textos, mas a própria interpretação que se costuma fazer da sua obra. Para alguns comentadores, como Camille Limoges ou Jean-Pierre Séris, mais que destacar um interesse de filósofo por uma disciplina que até pouco tempo era um campo de investigação da Filosofia, os textos de Macherey, Lecourt e Foucault difundiram a ideia de que a história das ciências para Canguilhem era "uma vocação, uma segunda ou até mesmo uma primeira natureza"10.

Para Limoges, o problema é que as interpretações que fizeram de Canguilhem um historiador das ciências "por natureza" capturaram apenas um instantâneo da sua obra, um corte bastante limitado da sua vastíssima produção, restrito ao período em que já se pode fazer sentir a presença da figura paterna de Gaston Bachelard e imprimir em seus textos a marca da “epistemologia histórica". Quando o Ensaio sobre alguns problemas relativos ao normal e ao patológico, tese de doutorado em medicina, foi publicado em 1943, Canguilhem já tinha 39 anos. Foi apenas aos 51 que ele obteve o doutorado em filosofia com a tese sobre a história do conceito de reflexo e assumiu seu posto na Sorbonne e seu cargo no Institut d'histoire des

\footnotetext{
${ }^{9}$ CANGUILHEM e PROUST, "La médecine et son histoire", p. 42.

${ }^{10}$ SÉRIS, “L’histoire et la vie”, p. 90.
} 
sciences et des techniques. Nesse intervalo, escreveu diversos artigos, sobre os mais variados temas filosóficos, que nem sempre foram levados em consideração pelos seus comentadores. Com o conhecimento de que se dispõe, hoje, da real extensão dessa produção, a constatação de Limoges é que o encontro de Canguilhem com a história das ciências é um acontecimento tardio da sua "história intelectual pessoal" cuja explicação reside menos na concretização de seu projeto filosófico - "um duplo jogo de interrogações, de uma parte sobre o valor da verdade em relação aos outros valores, e de outra parte sobre a precariedade criadora do ser vivo"11 - do que na necessidade de cumprir de modo apropriado as exigências do seu ofício. Para Limoges, foram as novas funções de professor de História e Filosofia das Ciências e de diretor do Institut d'histoire des sciences et des techniques, assumidas em 1955, que "criaram nele a obrigação - e também multiplicaram as ocasiões - de assumir intensamente seu novo papel". Em suma, Canguilhem teria sido historiador das ciências apenas enquanto foi professor de história das ciências na Sorbonne.

Um dos principais responsáveis pela publicação das obras completas de Canguilhem, e também seu ex-aluno, Limoges fala com a convicção dos números:

Os títulos em história das ciências representam pouco mais de $15 \%$ da produção total de Canguilhem; a epistemologia cerca de 27\%. As publicações filosóficas sem caráter propriamente epistemológico, que são as mais numerosas (pouco mais de $30 \%$ do total), são também aquelas cuja abundância foi a mais precoce e cujo crescimento numérico permanece o mais uniforme (com uma aceleração ao longo dos anos de aposentadoria, período em que os trabalhos de história das ciências, pelo contrário, enfrentaram uma desaceleração). ${ }^{12}$

A maioria dos testemunhos sobre Canguilhem vem de seus ex-alunos, que costumam ressaltar a "presença institucionalmente forte e brilhante" (palavras de Claire SalomonBayet $^{13}$ ) na Sorbonne do professor de história e filosofia das ciências que, discretamente, ajudou a construir o ambiente intelectual francês da segunda metade do século XX. Pierre Bourdieu, em sua Esquisse pour une auto-analyse, se vangloria da afinidade de habitus mantida com Canguilhem, a "figura exemplar" e "verdadeiramente universal" do racionalismo francês, o "emblema totêmico", o "farol", o "maître à penser" com quem aprendeu "a conceber a possibilidade realística de viver de maneira diferente a vida

\footnotetext{
${ }^{11}$ LIMOGES, “L'épistémologie historique dans l'itinéraire intellectuel de Georges Canguilhem", p. 65.

${ }^{12}$ Ibidem, p. 64.

${ }^{13}$ SALOMON-BAYET, "Georges Canguilhem et son temps", p. 7.
} 
intelectual”"14. Em 1990, Canguilhem, que veio a falecer cinco anos depois, aos noventa e um, enviou a seguinte mensagem aos organizadores de um colóquio em sua homenagem: "Não me é possível, na minha idade, fazer outra coisa além daquilo que sempre fiz, ou seja, não é possível que eu considere aquilo que é chamado de minha obra como algo diferente da marca do meu ofício. É comovente que alguns dos meus antigos alunos o reconheçam" ${ }^{\prime 15}$. Não se trata de modéstia: os arquivos pessoais e de trabalho de Canguilhem, preservados no CAPHÉS, o Centre d'Archives en Philosophie, Histoire et Édition des Sciences, da École Normale Supérieure de Paris, permitem comprovar que todos os textos de história das ciências tiveram origem nos cursos ministrados por Canguilhem. Nesse cenário, a explicação para aquela imagem construída por Macherey, Lecourt e Foucault passaria pelo fato deles figurarem também entre os alunos mais destacados de Canguilhem nos anos 60 .

Introduzir, se não uma descontinuidade, ao menos um descompasso entre o projeto filosófico e o ofício, como propôs Limoges, não significa negar inteiramente que Canguilhem foi um historiador excepcional, mas pretende reavaliar o papel da história das ciências no seu percurso intelectual para fazer emergir do cinza dos documentos a figura resplandecente do filósofo "por inteiro", que escreveu sobre o pensamento científico, mas também sobre lógica, moral, pedagogia, política etc. Essa ambição é sustentada pela leitura renovada da sua obra, mas incluindo agora textos que durante muito tempo sequer foram considerados no corpus canguilhemiano. Em 1985, uma edição da Revue de métaphysique et de morale inteiramente dedicada a Canguilhem informou que sua obra começava em 1943, com a publicação da tese de doutorado em medicina, o Ensaio sobre alguns problemas relativos ao normal e ao patológico. A bibliografia crítica organizada por Camille Limoges em $1994^{16}$ foi a primeira a mencionar o Traité de logique et de morale, publicado por Canguilhem e Camille Planet em 1939, além de informar sobre dezenas de textos virtualmente inéditos, publicados sob o pseudônimo G. C. Bernard na Libre propos, a revista fundada por Alain, e até mesmo clandestinamente, quando Canguilhem atendia pelo codinome Lafont, Médico Tenente e Chefe do Estado-Maior político da Résistance durante a ocupação da França pelos nazistas. Isso sem falar nos manuscritos, milhares de páginas que não poderão ser publicadas, respeitando a vontade manifesta do próprio Canguilhem, mas que estão à disposição dos pesquisadores no CAPHÉS e servem de apoio às novas interpretações.

\footnotetext{
${ }^{14}$ BOURDIEU, Sketch for a Self-analysis, p. 26-34, passim.

${ }^{15}$ CANGUILHEM apud DEGUY, "Allocution de clôture", p. 324. Trata-se do colóquio "Georges Canguilhem, philosophe, historien des sciences", realizado no Collège international de philosophie.

${ }^{16}$ LIMOGES, “Critical bibliography”, p. 385-454.
} 
O levantamento documental para edição das Euvres complètes recuou o início da produção intelectual de Canguilhem para o ano de 1926, fazendo aparecer o "Canguilhem avant Canguilhem", expressão de Jean-François Braunstein ${ }^{17}$, já de uso corrente entre os comentadores que se dedicam aos textos anteriores ao Ensaio de 1943. Apesar dessa valorização dos primeiros escritos de Canguilhem, Braunstein não acompanha Camille Limoges até o fim em sua interpretação sobre as razões da chegada de Canguilhem aos problemas da história das ciências. Para Braunstein - outro membro do Comitê Editorial das Euvres complètes de Canguilhem; codiretor do primeiro tomo, que abrange o período de 1926 a 1939 - os escritos do "primeiro Canguilhem" nos levam a "melhor compreender a evolução ulterior da obra (...), o que permite retificar a imagem corrente que faz de Canguilhem um puro historiador das ciências ou um simples continuador da obra de Bachelard"18. Aqui, a desnaturalização da imagem de Canguilhem como historiador das ciências é razão para a reflexão sobre a construção dessa imagem e sobre os elementos que permitiram que ela se consolidasse. É uma problemática forjada pela história intelectual, que não é uma história da filosofia envergonhada consigo mesma, mas uma história que, na expressão de François Azouvi, “aceita procurar pelos cantos":

Não são somente os livros que escapam, são por vezes pedaços de filosofia, se você preferir, que são relativamente autônomos. Creio nessa autonomia das ideias com relação àqueles que as emitem, com relação aos livros em que se as encontra, e essa autonomia das ideias explica sua vida, sua vida póstuma por vezes ou em todo caso sua vida independente dos autores, através de mundos extraordinariamente variados. É a razão pela qual há uma outra maneira de fazer a história da filosofia, que seria escrever justamente interessando-se pela maneira como as ideias migram de seu terreno de origem e deslocam-se em constelações intelectuais, políticas ou artísticas muito diversas. ${ }^{19}$

\section{A fagocitose althusseriana}

Em janeiro de 1970 Althusser enviou uma carta a Ben Brewster, tradutor estadunidense de Pour Marx. Brewster havia acrescentado à sua tradução um glossário de termos técnicos do marxismo relevantes para a compreensão da obra de Althusser e também

\footnotetext{
${ }^{17}$ Cf. BRAUNSTEIN. “Canguilhem avant Canguilhem”, pp. 9-26.

${ }^{18}$ Ibidem, p. 10.

${ }^{19}$ CAMOLEZI, “Bergson revisitado: entrevista com François Azouvi”, p. 121.
} 
de conceitos althusserianos, como o de corte epistemológico (epistemological break, na tradução em inglês). Segundo o tradutor, a coupure épistémologique é um conceito introduzido por Bachelard em La formation de l'esprit scientifique, de 1938, e utilizado por Canguilhem e Foucault em estudos de história das ideias. Brewster segue explicando que o corte epistemológico descreve um "salto do mundo das ideias pré-científico para o mundo científico", que esse salto "envolve um corte radical com todo o padrão e moldura de referência das noções pré-científicas (ideológicas), e a construção de um novo padrão (problemática)". Por fim, informa que Althusser utiliza esse conceito para descrever "a rejeição por Marx do hegelianismo e do feuerbachianismo da sua juventude e a construção dos conceitos básicos de dialética e materialismo histórico em seus trabalhos subsequentes"20. Althusser acreditava que o glossário poderia realmente ajudar a tornar sua obra mais acessível para os leitores ingleses, mas se sentiu obrigado a indicar correções necessárias acerca da sua relação com Canguilhem. Assim, na Letter to the Translator, alerta que:

Canguilhem viveu e pensou em contato próximo com a obra de Bachelard durante muitos anos, então não é surpreendente se ele se refere algumas vezes ao termo "corte epistemológico", embora esse termo raramente possa ser encontrado nos textos de Bachelard (por outro lado, se o termo é incomum, a coisa está lá o tempo todo a partir de um ponto específico da obra de Bachelard). Mas Canguilhem não usa esse conceito sistematicamente, como eu tentei fazer. (...) O uso do conceito de "corte" em Canguilhem é diferente do meu, embora sua interpretação tenda a ir na mesma direção. De fato, isso deveria ser colocado em sentido inverso: meu débito com Canguilhem é incalculável, e é a minha interpretação que tende a ir em direção à dele, sendo uma continuação da dele, indo além do ponto onde ele parou (ao menos por enquanto). ${ }^{21}$

Num plano pessoal, a aproximação entre os dois filósofos começou quando Canguilhem deixou Estrasburgo em direção a Paris em 1948, mesmo ano em que Althusser se tornou professor na École Normale Supérieure. Foram as tarefas burocráticas que promoveram o encontro, pois Canguilhem assumira o posto de Inspetor Geral de Instrução Pública, enquanto Althusser se tornou membro do júri de agrégation (um concurso nacional anual para recrutamento de professores de liceu na França). "Eu não lhe parecia muito reacionário e ele não me pareceu muito obtuso. Então, aos poucos, viemos a nos entender bem", relatou Canguilhem sobre esse encontro, décadas depois ${ }^{22}$. Os dois se mantiveram

\footnotetext{
${ }^{20}$ BREWSTER, “Glossary”, p. 310. In: ALTHUSSER e BALIBAR, Reading Capital, Nova Iorque: 1970.

${ }^{21}$ Idem.

${ }^{22}$ BING e BRAUNSTEIN, “Entretien avec Georges Canguilhem”, p. 126-27.
} 
próximos pelo menos até o início da década de 70, quando Canguilhem se aposentou da Sorbonne. Em 1980, um episódio dramático: Althusser, num surto psicótico, estrangula sua esposa. Julgado inimputável, foi internado, não por muito tempo, num hospital psiquiátrico. Nos arquivos de Canguilhem, encontramos uma pasta com diversos recortes de jornal sobre o acontecimento, além de uma carta de Althusser, datada de 6 de julho de 1986, enviada do hospital psiquiátrico l'Eau Vive, em Soisy-sur-Seine, onde ele estava novamente internado: "Escrevo para dizer que tenho uma dívida infinita com você. Eu li O normal e o patológico, e nada mais. Isso foi suficiente para compreender você e compreender que você era meu "mestre"'. Talvez a confusão de Althusser explique essa afirmação de que ele não teria lido nada além de $O$ normal e o patológico. Sabemos, por exemplo, (graças ao minucioso trabalho de Camille Limoges) da existência, no Fonds Althusser, preservado no IMEC, de notas para um artigo inacabado no qual Althusser discutia em detalhe as teses vitalistas expostas por Canguilhem em $O$ conhecimento da vida. Essas anotações datam de meados da década de cinquenta $^{23}$.

A proximidade entre os dois, mais especificamente, o reconhecimento e os elogios públicos que Althusser sempre rendeu a Canguilhem, garantiram, num primeiro momento, um público maior para nosso autor, mas também contribuíram para seu apagamento quando o cenário intelectual francês mudou. Numa entrevista recente com Jean-François Braunstein que publicamos na revista de história intelectual Intelligere, o professor da Sorbonne avaliou que uma das razões para o eclipse da epistemologia histórica na França, em oposição à vitalidade que hoje conhece em outros países, tem como primeira explicação o fato de que Canguilhem foi "fagocitado" por Althusser e pelos althusserianos: "acreditou-se que Canguilhem era apenas um althusseriano dentre outros, ou uma espécie de marxista, o que é evidentemente absurdo, inteiramente contrário às próprias ideias de Canguilhem" ${ }^{\text {, } 4}$. De fato, muitas das críticas endereçadas a Canguilhem a propósito das relações entre ciência e ideologia não tem sua origem nos textos de Canguilhem, sequer naquilo que Althusser disse de Canguilhem, mas naquilo que Althusser pretendeu fazer apoiado na leitura de Canguilhem. Por outro lado, o interesse de Althusser e de seus discípulos pela obra de Canguilhem foi o principal impulso para a sua projeção para além do solo francês, inclusive para sua recepção no Brasil.

Em 1964, quando Macherey publicou seu artigo em La Pensée, revista multidisciplinar ligada ao Partido Comunista Francês, Canguilhem ainda não era "o autor de O normal e o patológico", publicado apenas dois anos depois. Isso não impediu que, na

\footnotetext{
${ }^{23} C f$. LIMOGES, Introduction. In: CANGUILHEM, Euvres Complètes, t. IV, p. 45.

${ }^{24}$ ALMEIDA e CAMOLEZI, “Entrevista com Jean-François Braunstein”, p. 161.
} 
apresentação ao artigo, Althusser profetizasse: "seu nome [o de Canguilhem] e sua obra irão logo conhecer um público mais amplo" ${ }^{, 25}$. O texto de Lecourt, por sua vez, foi encomendado por um editor, por recomendação de Althusser, para servir de prefácio à tradução argentina de O normal e o patológico, publicada em 1971. Em "La historia epistemológica de Georges Canguilhem" Lecourt afirmou que se tratava de reconhecer uma "dívida teórica inestimável" dos "filósofos marxistas-leninistas agrupados em torno de Louis Althusser" 26 com os trabalhos de Canguilhem. No prefácio à tradução estadunidense de $O$ normal e o patológico, publicada em 1978, Foucault avaliou aquele contexto intelectual: "Esqueçam Canguilhem”, escreveu, "e vocês não compreenderão mais grande coisa sobre Althusser, o althusserismo e toda uma série de discussões que ocorreram entre os marxistas franceses" ${ }^{, 27}$.

“Os novos epistemólogos”, escreveu Althusser na longa apresentação ao texto de Macherey, “são semelhantes aos etnólogos, que vão 'ao campo': eles vão ver a ciência de perto, e não aceitam falar daquilo que eles ignoram, ou daquilo que conhecem apenas de segunda ou terceira mão (era, infelizmente, o caso de Brunschvicg) ou percebem de fora, quer dizer, de longe.” ${ }^{28}$ Cinquenta anos atrás, quando aproximar epistemologia e etnologia ainda não era considerado uma heresia, Althusser afirmava uma descontinuidade na história da filosofia que, segundo ele, teria sido provocada pelas novas vias abertas, "em epistemologia, por Jean Cavaillès, Gaston Bachelard e Jules Vuillemin", e, "em história das ciências, por Canguilhem e Foucault". Embora divida as competências, para Althusser o elemento revolucionário era o fato de que, a partir daqueles autores, epistemologia e história das ciências remetiam uma à outra em profunda unidade. "É justamente essa unidade que se constitui atualmente em problema e dificuldade", afirmou.

Nos anos 60, a unidade entre epistemologia e história das ciências apareceu como a resposta ao problema filosófico da historicização das ciências, da atribuição, ou antes, do reconhecimento de uma historicidade própria ao pensamento científico que não fosse uma imagem da arquitetônica da Razão. Daí que, para Althusser, além do respeito pela "realidade da ciência real", em oposição à imagem de ciência projetada pelo idealismo, a segunda grande novidade trazida pela obra de Canguilhem seria a "exigência elementar" de não tomar uma crônica ou filosofia da história “(ou seja, uma concepção ideológica da história, do progresso

\footnotetext{
${ }^{25}$ ALTHUSSER, “Présentation”, In: MACHEREY, "La philosophie de la Science de Georges Canguilhem: Épistémologie et Histoire des Sciences", p. 50.

${ }^{26}$ LECOURT, "La historia epistemologica de Georges Canguilhem". In: CANGUILHEM, Lo normal y lo patológico, p. VII.

${ }^{27}$ FOUCAULT, "Introduction", p. 8. In: CANGUILHEM, The normal and the pathological.

${ }^{28}$ ALTHUSSER, "Présentation", p. 51-52.
} 
da história, do progresso da Razão etc.) como a História." ${ }^{29}$. Como resultado dessas duas novidades, segundo Althusser, "as velhas concepções tradicionais, empiristas, positivistas, idealistas, da epistemologia e da história" foram profunda e irreversivelmente alteradas ${ }^{30}$.

“A obra epistemológica e histórica de G. Canguilhem”, escreveu Macherey em seu artigo, "impressiona primeiro pela sua especialização"; Dominique Lecourt, naquele prefácio, quis explicar o encontro entre as preocupações teóricas dos marxistas franceses com "os trabalhos de História das Ciências estritamente especializados" de Georges Canguilhem; segundo Foucault, na introdução à tradução estadunidense, a obra de Canguilhem "é austera, voluntariamente e cuidadosamente limitada a um domínio particular de uma história das ciências". Desde a abertura dos seus arquivos pessoais e de trabalho e a publicação das suas obras completas, que nos informaram sobre os vários domínios aonde a atividade filosófica conduziu Canguilhem, dificilmente alguém começaria dessa maneira um comentário sobre sua obra. Mas fazia sentido que, à época, a primeira característica apontada pelos três autores fosse a especialização. Mais tarde, no prefácio ao livro De Canguilhem à Foucault, la force de las normes, Macherey explicou que, para escrever a apresentação sobre Canguilhem publicada em La Pensée, "a primeira tarefa, particularmente trabalhosa, foi reunir um corpus a partir do qual estudar" ${ }^{\prime 3}$. No texto de 1964, publicado em La Pensée, ele listou os trabalhos utilizados na sua pesquisa: os livros Ensaio sobre alguns problemas relativos ao normal e ao patológico, La formation du concept de réflexe au XVII et XVIII siècles e $O$ conhecimento da vida; os textos "Introduction au traité de physiologie de Kayser", "Pathologie et physiologie de la thyroide au XIXe siècle", "Note sur la situation faite à la philosophie biologique en France”, “Qu'est-ce que la psychologie?", “Une epistémologie concordataire”, "L’histoire des sciences dans l'oeuvre épistémologique de Gaston Bachelard", "Les fonctions de la thyroïde", "La psychologie animale et la psychologie humaine d'après Darwin", "La diffusion scientifique", "Gaston Bachelard et les philosophes", "The role of analogies and models in biological discovery", e as participações na obra coletiva Du développement à l'évolution au XIXe siècle, originalmente publicada na revista Thales, e no livro Histoire générale des sciences, dirigido por René Taton.

Não se trata de uma seleção. Macherey tentou ser o mais exaustivo possível no levantamento da bibliografia. Os textos reunidos "a muito custo", segundo ele, dão a ideia mais completa sobre "como se apresentava a obra de Canguilhem no começo dos anos

\footnotetext{
${ }^{29}$ ALTHUSSER, “Apresentação”, p. 245. In: CANGUILHEM, O normal e o patológico.

${ }^{30}$ Ibidem, p. 246.

${ }^{31}$ MACHEREY, De Canguilhem à Foucault, la force des normes, p. 20.
} 
sessenta aos olhos daqueles que tiveram sua curiosidade despertada por ela",32. Ao longo de vinte anos, a especialização dessa obra em um domínio particular da história das ciências, as ciências da vida, não escondia a diversidade dos objetos - os estados normal e patológico, o vitalismo, o meio, o conceito de reflexo, a monstruosidade e os monstros, as funções da glândula tireoide, as teorias fibrilar e celular - e a diversidade das temáticas (ou níveis de análise) - a teoria das ciências, a história das ciências, a teoria da história das ciências. Mas, avaliou Macherey, cada um desses níveis de análise não serve de pretexto para os outros. Embora possamos distingui-los e ler de maneira diferente cada texto de Canguilhem, não podemos dissociá-los. $\mathrm{Na}$ obra de Canguilhem, a diversidade dos objetos e das temáticas indica a unidade da reflexão. E, "através da diversidade dos assuntos e pontos de vista, objeto ou questão não se apresentam jamais senão na discursividade de uma sucessão, de um desenrolar. Parece, desde o princípio, que os fenômenos não adquirem sentido senão refletidos em sua história" ${ }^{33}$.

Macherey descreve a obra de Canguilhem como "essencialmente polêmica", querendo dizer que ela não se limita a fazer a descrição das ciências ou louvar seus resultados. Essa obra levanta o tempo todo a questão "O que quer a ciência?”, ou, mais especificamente, "O que quer essa ciência particular?". Foi essa a problematização que, na opinião de Macherey, teria feito Canguilhem se afastar definitivamente dos historiadores da sua época, mas para instituir uma nova maneira de pensar e escrever a história das ciências. Nem Limoges pôde deixar de reconhecer a Macherey o mérito de ter descrito, precocemente, eficazmente e com riqueza de detalhes a postura de um epistemólogo e historiador das ciências. De fato, entre os vários méritos do texto de Macherey, é preciso destacar que ele identificou aquela que, durante muito tempo, apareceria como a característica distintiva da obra de Canguilhem: a história dos conceitos. Consideremos as citações que servem de epígrafes ao artigo de Macherey, a primeira, retirada da "Introduction au Traité de physiologie de Kayser”: “A história de uma ciência não pode ser uma simples coleção de biografias, muito menos um quadro cronológico amenizado por anedotas. Ele deve ser também uma história da formação, da deformação e da retificação dos conceitos científicos ${ }^{34 » ;}$ e a segunda, citada por Macherey a partir do artigo "Pathologie et physiologie de la thyröide au XIX siècle": "Uma história bem feita, qualquer história que seja, é aquela que consegue tornar

\footnotetext{
${ }^{32}$ Ibidem, p. 19.

${ }^{33}$ MACHEREY, “A filosofia da ciência de Georges Canguilhem”, p. 251.

${ }^{34}$ CANGUILHEM, "Introduction au Traité de physiologie de Kayser”, p. 18.
} 
sensível a opacidade e a espessura do tempo."35

Ao optar pelos conceitos, Canguilhem escrevia contra a história das ciências enquanto história das teorias científicas, melhor dizendo, contra certo tipo de história das ciências segundo a qual os conceitos derivam das teorias pelas quais eles são explicados, ou seja, segundo a qual não apenas os conceitos só teriam sentido no interior das teorias, como qualquer mudança na teoria exigiria uma imediata reformulação do conceito. Foi em $L a$ formation du concept de réflexe aux XVII et XVIII siècles, livro de 1955, que Canguilhem desenvolveu de maneira mais aprofundada essa nova forma de escrever a história das ciências. Para Canguilhem, as fontes da interpretação equivocada segundo a qual Descartes teria introduzido o conceito de reflexo na fisiologia são, primeiro, a confusão da identificação e descrição de um fenômeno com a sua interpretação conceitual específica e, em seguida, a falta de clareza na distinção entre história das teorias e história dos conceitos. O conceito de reflexo desempenhou um papel fundamental nas teorias mecanicistas do organismo, o que conduziu os cientistas que veem na história das ciências uma sucessão de teorias à fácil interpretação de que a descrição do movimento reflexo por uma teoria mecanicista era equivalente à formulação do conceito de reflexo por essa mesma teoria.

Ora, conforme Canguilhem, o conceito de "reflexo" só pôde surgir graças ao vitalismo, com a figura do físico inglês Thomas Willis, que entendia a vida como luz. Foi a compreensão do motus reflexus como refração da luz que articulou, na obra de Willis, o elemento central do conceito de reflexo, a saber, a distinção do cerebelo, como centro do movimento involuntário, do cérebro, como centro do pensamento racional e ação voluntária. Canguilhem ainda mostrou como o conceito vitalista de reflexo, proposto por Willis no século XVII, pôde se generalizar e alcançar sucesso efetivo numa explicação mecanicista da vida animal, levando muitos historiadores à suposição de que tal conceito não poderia ter surgido fora do pensamento mecanicista, recuado, neste caso, até a figura ilustre de Descartes.

Para Canguilhem, o conceito é "um nome carregado de um sentido, capaz de cumprir uma função de discriminação na interpretação de certas observações ou experiências" ${ }^{\text {"36. Os }}$ conceitos são a primeira formulação racional de um fenômeno, a partir de onde serão construídas as teorias para explicá-lo, permitindo, inclusive, que teorias concorrentes se valham do mesmo conceito. Ao passar da teoria ao conceito, Canguilhem atacava um problema geral em História das Ciências, a ideia de que "um conceito não pode aparecer senão no contexto de uma teoria ou, pelo menos, numa inspiração heurística homogênea

\footnotetext{
${ }^{35}$ CANGUILHEM, "Pathologie et physiologie de la thyröide au XIX siècle", p. 78.

${ }^{36}$ CANGUILHEM, "Le concept de réflexe au XIX ${ }^{\mathrm{e}}$ siècle", p. 295.
} 
àquelas em que os fatos de observação correspondentes serão interpretados posteriormente",37. Nas palavras de Macherey:

O nascimento de um conceito é, portanto, um começo absoluto: as teorias, que são como a "consciência" dele, não vem senão depois, e muitas excrescências teóricas podem-se enxertar em um mesmo conceito. A indiferença do conceito nascente no contexto teórico desse nascimento lhe dá sua primeira determinação, que é, para ele, a promessa de uma história verdadeira: a polivalência teórica. A aventura do conceito estará, por um lado, na sua passagem de um contexto teórico a outro. ${ }^{38}$

A "aventura dos conceitos", sua "polivalência teórica": golpes contra a filosofia continuísta dos progressos da razão, que se sustentava numa história das ciências que forçava os acontecimentos ao enquadramento numa linha ininterrupta onde todas as novas teorias científicas deveriam necessariamente ser deduzidas das anteriores, para o que contribuía em muito a erudição acerca dos grandes nomes e das grandes descobertas. Essa nova compreensão da história dos conceitos e da sua relação com as teorias, na opinião de Althusser e Macherey, condenava os dois principais tipos de história das ciências escritos até meados do século passado: a contingente, na medida em que eliminava a impressão da história como uma sucessão de descobertas e invenções, mostrando em vez disso todo o trabalho de maturação conceitual e experimentação racional que fundamenta o discurso científico; e a história lógica, que seguia pela determinação dos avanços científicos como progressos da razão, como se a ciência se resumisse ao processo de resolução, por uma nova teoria, de problemas não resolvidos por uma teoria anterior e ao acúmulo contínuo de conhecimentos. "A realidade tem um pouco mais de imaginação", afirmou Althusser:

Existem questões que jamais terão respostas, posto que são questões imaginárias, que não correspondem a problemas reais; existem respostas imaginárias, que deixam sem verdadeira resposta o problema real a que elas aludem; existem ciências que se dizem ciências, mas que não passam de imposturas científicas de uma ideologia social; existem ideologias nãocientíficas que, através de encontros paradoxais, fazem nascer verdadeiras descobertas - como vemos o fogo surgir do choque de dois corpos estranhos. Por isso, toda a complexa realidade da história, em todas as suas determinações - econômicas, sociais, ideológicas -, entra em jogo na inteligência da própria história científica. A obra de Bachelard, de Canguilhem e de Foucault nos dá a prova. ${ }^{39}$

\footnotetext{
${ }^{37}$ Idem.

${ }^{38}$ MACHEREY, “A filosofia da ciência de Georges Canguilhem, p. 260.

${ }^{39}$ ALTHUSSER, “Apresentação”, p. 258.
} 
Nos trabalhos de Canguilhem, portanto, a ciência não seria a constatação da verdade nua, descoberta, mas uma produção de conhecimentos com pretensão de verdade, estabelecidos em relação com a não-ciência. Assim, a profunda unidade entre Epistemologia e História na obra de Canguilhem teria permitido, segundo Althusser, uma concepção verdadeiramente racional dos objetos da História das Ciências. Em suma, Canguilhem teria afastado definitivamente o racionalismo do idealismo, permitindo aproximá-lo do materialismo. Foi animado por essa ideia que Althusser propôs a Pierre Macherey, então jovem estudante da École normale supérieure, que apresentasse para seu grupo de estudos uma comunicação sobre a obra do professor que tanto o havia impressionado. Convidado por Althusser para assistir à conferência, Canguilhem, segundo relato de Macherey, manifestou apenas uma reserva: a ausência, num comentário sobre sua obra, de referências a Nietzsche, já naquela época muito importante em sua orientação filosófica pessoal. Macherey também admitiu ter percebido a surpresa de Canguilhem quando ouviu sua obra e seu pensamento aproximados do materialismo dialético. "No entanto, ele deve ter guardado uma boa impressão da minha apresentação", escreveu Macherey, "pois, em seguida, ele falou com Foucault, que propôs que eu transformasse a exposição em um artigo para ser publicado em Critique, a prestigiosa revista da qual ele fazia parte do comitê de redação."40

O destino do artigo, sabemos, foi outro. Ele apareceu em La Pensée, uma das revistas teóricas do Partido Comunista Francês (PCF), onde o próprio Althusser já havia publicado diversos textos, alguns deles reunidos no livro Pour Marx. A publicação tinha um forte tom de provocação. Canguilhem, apesar de seu reconhecido heroísmo durante o combate aos nazistas, era persona non grata entre os militantes do PCF. Na França, não foram poucos os filósofos e os professores de filosofia que aderiram ao partido. Tinham a tendência, segundo testemunho do próprio Macherey, de transformar suas salas de aula em tribunas, prática que Canguilhem, enquanto Inspetor Geral de ensino na França, condenava com intransigência ${ }^{41}$. Antes mesmo, nos anos que antecederam a Segunda Guerra, enquanto militante do Comité de vigilance des intellectuels antifascistes, Canguilhem escreveu o livro Les paysans et le fascisme, onde atacava o dogmatismo dos stalinistas em relação aos trabalhadores do campo, alertando que suas palavras de ordem pelo fim da pequena propriedade rural - uma das conquistas populares da Revolução Francesa - servia apenas para aproximar os camponeses dos fascistas. Talvez até mais que uma provocação, era quase absurdo que um elogio de

\footnotetext{
${ }^{40}$ MACHEREY, De Canguilhem à Foucault, la force des normes, p. 20.

${ }^{41}$ Ibidem, p. 23.
} 
Canguilhem fosse publicado num órgão oficial do PCF. Não para Althusser: "É justo que a revista fundada por Langevin acolha o primeiro estudo aprofundado que lhe é consagrado [a Canguilhem] na França”, avaliou ${ }^{42}$.

Em 1964, quando Macherey publicou seu artigo, Althusser não era um recémchegado à discussão sobre as relações entre epistemologia e história. Havia mesmo defendido, sob a orientação de Bachelard, uma dissertação de mestrado sobre Hegel. Como lembra Macherey, Althusser valia-se largamente das contribuições "da nova epistemologia à francesa para dar bases 'científicas' sólidas à sua empreitada de reforma do marxismo" ". Sabemos que, como parte desse esforço, Althusser valeu-se do conceito de "ruptura", de Bachelard, tornado "corte epistemológico" em sua obra. Para muitos marxistas, a Epistemologia era uma ideologia completamente alheia às condições materiais de produção do discurso científico, mas o trabalho teórico de Bachelard e Canguilhem permitiu que Althusser fizesse a crítica desse tipo de formulação simplista da relação entre as ciências e suas condições sociais de produção. Os textos de Canguilhem apareciam para Althusser como um aprofundamento do caráter histórico do pensamento formal, mostrando como a ciência, tomada em seu aspecto teórico, emergia de determinações históricas que poderiam ser diretamente relacionadas às condições gerais da economia e da ideologia dominantes. Apoiado nos trabalhos de Bachelard e Canguilhem, Althusser pretendeu que, através da Epistemologia e da História, era possível identificar esses elementos perniciosos disfarçados de ciência ao qual deu o nome de "ideologia" e, assim, reafirmar o caráter científico da obra de Marx. A ruptura da ciência com a ideologia foi justamente o movimento que Althusser pretendeu demonstrar a partir de $O$ Capital, de Marx, que, na sua leitura, através da "verdadeira ciência" do Materialismo Histórico, representaria um corte epistemológico em relação à Economia Política de Ricardo, uma ideologia burguesa.

Na sequência da publicação do artigo nas páginas de La Pensée, Canguilhem, que, segundo Macherey, “estava perfeitamente informado, e era totalmente indiferente, acerca da má reputação que ele tinha na esfera de influência do PCF"44, ficou inicialmente surpreso ao perceber a aproximação e o reconhecimento, por parte de pesquisadores que faziam parte daquela esfera, dos méritos do seu trabalho teórico e do seu ensino universitário. Achava divertido um elogio ao seu trabalho teórico publicado num órgão oficial do stalinismo francês.

\footnotetext{
${ }^{42}$ ALTHUSSER, “Apresentação", p. 250. Paul Langevin (1872-1946) foi um eminente físico francês e um dos fundadores do Comité de vigilance des intellectuels antifascistes.

${ }^{43}$ MACHEREY, Op. cit., p. 25.

${ }^{44}$ Ibidem, p. 24.
} 
Sem tomar parte, nesse primeiro momento, na discussão sobre a relação entre cientificidade e ideologia, Canguilhem continuou tratando com Althusser e com o círculo de jovens filósofos althusserianos que frequentavam, cada vez mais numerosos, seus cursos de história e filosofia das ciências, mas, segundo Macherey, mostrou-se incomodado ao perceber a quais fins aquela recuperação da sua obra, e da de Bachelard, servia.

Ele nunca me reprovou, nunca emitiu nenhuma reserva a propósito do meu artigo: simplesmente, muito mais tarde, quando uma editora universitária brasileira publicou uma edição de $O$ normal e o patológico, tendo como posfácio uma retomada desse artigo [com a apresentação de Althusser], ele me fez entender que considerava aquilo inapropriado. Para dizer rapidamente, aos seus olhos, a página estava virada. ${ }^{45}$

A decisão de incluir o texto de Macherey, com a apresentação de Althusser, como posfácio à tradução brasileira do livro de Canguilhem a partir da sua segunda edição, em 1982 (a primeira é de 1978), também deve ser entendida no contexto da recepção de Althusser no Brasil, fortemente marcada pelo nome de Carlos Escobar, em torno de quem se organizou um círculo de intelectuais dedicados ao estudo e à divulgação da obra do filósofo marxista. Entre esses intelectuais, estavam Manoel Barros da Motta e Severino Bezerra Cabral Filho, organizadores da Coleção Campo Teórico, da Editora Forense Universitária, por onde foram publicados não apenas $O$ normal e o patológico, mas também $O$ nascimento da clínica, $A$ arqueologia do saber e Raymond Roussel, de Michel Foucault. Se Canguilhem considerava o assunto já superado em 1982, é porque, em 1977, motivado pelos debates travados entre Althusser e Foucault, já havia apresentado a um público mais amplo seu conceito de ideologia cientifica, desenvolvido, como de costume, em seus cursos na Sorbonne e no Institut. Os conceitos de ideologia científica e ideologia médica, últimas grandes contribuições de Canguilhem à historiografia, serão temas de uma exposição mais detalhada nos próximos capítulos.

Diferente do que aconteceu com a tradução brasileira, que apenas em sua segunda edição acrescentou os textos de Althusser e Macherey como posfácio, Lo normal y lo patológico, publicado em 1971 pela Editora Siglo XXI, contava com um prefácio de Dominique Lecourt encomendado especialmente para esse fim, por sugestão do próprio Althusser aos editores argentinos. Althusser acreditava que a noção de "ruptura" ou "corte epistemológico", que ele havia emprestado de Bachelard para fazer uma releitura científica da obra de Marx, necessitava de uma investigação mais criteriosa. Como não podia orientar

\footnotetext{
${ }^{45}$ Idem.
} 
dissertações de mestrado na École Normale Supérieure de Paris, onde lecionava, Althusser costumava sugerir aos jovens estudantes de filosofia que participavam de seu grupo de pesquisa que pleiteassem a orientação de Canguilhem na Sorbonne. Assim, em 1967, Lecourt se apresentou a Canguilhem como candidato a um mestrado sobre a obra de Bachelard. Nesse mesmo ano, passou a seguir os seminários de Canguilhem no Institut e, em 1968, depositou a dissertação L'épistémologie historique de Gaston Bachelard (ainda que, ao ver o título, Canguilhem tenha objetado: "Não. Não epistemologia histórica, mas história epistemológica"46). No ano seguinte, Canguilhem convidou Lecourt a publicar sua dissertação. Lançado em 1969 pela Vrin, na coleção dirigida por Canguilhem, que também escreveu seu prefácio, o livro foi imediatamente traduzido para diversas línguas e, aos 25 anos, Lecourt se tornou o responsável por apresentar ao mundo a "epistemologia histórica" 47 .

O texto de Lecourt não foge do quadro estabelecido pelos seus colegas marxistas. Porém, muito mais que Althusser e Macherey, Lecourt foi determinante para a transformação da filiação Bachelard-Canguilhem em dogma de história da filosofia francesa: "parece perfeitamente justificado considerá-lo o herdeiro de Bachelard. O reconhecimento da historicidade do objeto da epistemologia impõe uma nova concepção da história das ciências”. E sentencia: "A epistemologia de Gaston Bachelard era histórica; a história das ciências de Georges Canguilhem é epistemológica. Duas maneiras de anunciar a unidade revolucionária que ambos instituem entre epistemologia e História das Ciências”,48. Para Lecourt, pouco importa se a nova disciplina fundada por Bachelard em 1938, a psicanálise do espírito científico, que se propunha uma "catarse" do espírito científico, não tenha tido sucesso. O mais importante é que, ao falar do devaneio e da imaginação, Bachelard operou um movimento revolucionário: "Assinalou uma posição que nunca tinha sido ocupada: lugar vazio, mas reconhecido como tal, na junção entre cada prática científica e as ideologias que ali intervêm sob uma cobertura filosófica" ${ }^{, 49}$.

Lecourt iniciou o prefácio a Lo normal y lo patológico lamentando o fato de que o Ensaio, que compõe a primeira parte do livro de Canguilhem, tenha sido "deliberadamente ignorado" durante tanto tempo após a sua publicação em 1943, quando "os mortos"

\footnotetext{
${ }^{46}$ GAYON, "Bachelard et l'histoire des sciences", p. 53.

${ }^{47}$ Lecourt veria, naquele mesmo ano de 1971, seu artigo "A arqueologia e o saber" ser publicado na coletânea $O$ homem e o discurso (A Arqueologia de Michel Foucault), da editora Tempo Brasileiro, ao lado de artigos de Carlos Henriques Escobar, Sérgio Paulo Rouanet e de uma entrevista concedida por Michel Foucault a Rouanet e José Guilherme Merquior. Esse artigo é citado por Arouca em sua tese sobre o "dilema preventivista", que se reivindica do método arqueológico.

${ }^{48}$ LECOURT, "La historia epistemologica de Georges Canguilhem”, p. XI.

${ }^{49}$ Ibidem, p. X.
} 
dominavam o cenário filosófico. Tal como Macherey havia feito em seu artigo, Lecourt destacou que a recuperação da obra de Canguilhem naquele momento se deve a uma mudança nesse cenário, que passou a valorizar as críticas de Canguilhem ao dogmatismo, não apenas filosófico, mas historiográfico: “Canguilhem mostra que a 'história-crônica' e a 'históriacontingência' tem uma origem comum, que o mesmo mal as corrói, porque ambas se apoiam explicitamente ou não - numa certa filosofia da História"50. A opção de Canguilhem pela história dos conceitos, em vez da história das teorias, para Lecourt, é resultado da postura firme contra o "vírus do precursor", contra os "golpes de gênio", contra a "concepção dogmática da ciência” e contra uma "concepção dos 'progressos do espírito' que pertence à Aufklarüng, a Condorcet e a Comte".

Concebida como "História dos Conceitos", a História das Ciências faz aparecer filiações inesperadas, estabelece novas periodizações, faz surgir nomes esquecidos, faz cambalear a cronologia tradicional e oficial. Em poucas palavras: desenha uma 'história paralela' cuja particularidade reside em cruzar-se e chocar-se constantemente com o tranquilo discurso dos historiadores dogmáticos. ${ }^{51}$

O objetivo do prefácio de Lecourt é esclarecer ao leitor argentino o que, de longe, poderia parecer um "paradoxo", o encontro entre a história das ciências e as preocupações teóricas dos "filósofos marxistas-leninistas agrupados em torno de Louis Althusser". Lecourt explica que o paradoxo é apenas aparente, e as razões são fáceis de deduzir pelo que dissemos até aqui: a unidade entre epistemologia e história das ciências, possibilitada pela obra de Canguilhem, havia aproximado aquelas duas disciplinas do materialismo histórico, "a ciência marxista da História" ${ }^{25}$. No prefácio a Lo normal y lo patológico, Lecourt explica que essa unidade será vista em prática na história das ciências biológicas obedecendo a duas preocupações: a de mostrar o caráter específico do seu objeto, e a de precisar, baseando-se no caso específico da medicina, as relações entre técnicas e conhecimentos teóricos. "A leitura do livro Lo normal y lo patológico mostrará de modo insuperável que ambas as questões são estreitamente solidárias", escreveu Lecourt. "A primeira explica a insistência com a qual G. Canguilhem retorna sobre a chamada 'questão do vitalismo'. A segunda permite compreender a importância que concede à noção de 'norma'., 53

Não foi para reconstituir a formação de uma rede intelectual que nos interessamos

\footnotetext{
${ }^{50}$ Ibidem, p. XV.

${ }^{51}$ Ibidem, p. XX.

${ }^{52}$ Ibidem, p. VII.

${ }^{53}$ Ibidem, p. XXVII.
} 
pelos textos de Macherey, Lecourt e pelo destino da sua leitura. São a difusão e a recepção dos textos e, naturalmente, a difusão e a recepção das ideias que destacamos entre os principais objetos da história intelectual. Para François Azouvi, autor de livros como De Königsberg à Paris: La réception de Kant en France (1788-1804) e La gloire Bergson: essai sur le magistère philosophique, essa história é tão importante quanto a história dos sistemas, quer dizer, a história interna das obras de um autor: "acredito que haja aí um campo de pesquisa imenso, porque, na realidade, poderíamos retomar toda a história do pensamento e da filosofia ocidentais do ponto de vista de sua recepção, do ponto de vista do uso que foi feito das obras" ${ }^{54}$. Afinal, difusão e recepção não são noções passivas: elas pressupõem valoração e apropriação.

Escrever a história do pensamento dessa perspectiva implica necessariamente numa busca pela atribuição retrospectiva de sentido ao texto, à ideia e ao autor. Como dissemos, retificar a imagem corrente que faz de Canguilhem "um puro historiador das ciências ou um simples continuador da obra de Bachelard" significa desnaturalizar essa imagem, indicando, por um lado, a história da sua constituição e as condições que a tornaram possível, e, por outro, rastreando pelos textos a formação de um pensamento para fazer aparecer o historiador na evolução de uma obra, entendida não apenas como signo de um itinerário pessoal, mas também como síntese histórica de uma cultura intelectual.

\section{Um historiador das racionalidades}

O principal comentador da obra de Michel Foucault é, como se sabe, o próprio Foucault. Sua vasta produção, de uma originalidade indiscutível, é constituída também por vários artigos, ensaios e entrevistas - seus "ditos e escritos" - nos quais ele explica seus projetos e as inflexões no seu pensamento, esclarece questões levantadas por seus leitores e responde seus críticos. E, frequentemente, nesses textos Foucault dá testemunhos da sua formação intelectual e paga tributos aos autores que de alguma maneira o estimularam a seguir por determinada via de investigação. Assim, qualquer um que tenha lido meia dúzia dos seus principais textos certamente já se deparou com o nome de Georges Canguilhem, sempre em tom de reverência e reconhecimento de uma grande dívida intelectual. À medida que a fama de Foucault crescia, o reconhecimento do nome de Canguilhem oscilava: era cada

\footnotetext{
${ }^{54}$ CAMOLEZI, "Bergson revisitado: entrevista com François Azouvi”, p. 120.
} 
vez menos o discípulo de Bachelard e mais o mestre de Foucault.

Não obstante as diferenças significativas entre as obras de Canguilhem e Foucault, é impossível não ver as marcas da filiação - sobretudo porque o próprio Foucault fazia questão de realçá-las. E, quando o fazia, era para destacar a importância da formação em história das ciências que havia recebido de Canguilhem, como nessa entrevista concedida a Moriaki Watanabe em 1978, quando sua obra começava a ser traduzida no Japão e Foucault era convidado a se apresentar aos seus novos leitores:

Eu fui aluno de historiadores das ciências, aluno, por exemplo, de Georges Canguilhem, e meu problema era saber se não seria possível fazer uma história das ciências que tente recuperar o nascimento, o desenvolvimento, a organização de uma ciência não tanto a partir de suas estruturas racionais internas, mas a partir dos elementos exteriores que puderam lhe servir de suporte. Tanto que eu sempre oscilei, ou melhor, eu oscilei durante algum tempo, entre a análise interna dos discursos científicos e a análise das suas condições de desenvolvimento. Em História da loucura, eu tentei mostrar ao mesmo tempo como a psiquiatria havia se desenvolvido, quais temas ela havia abordado, quais objetos ela havia tratado, de quais conceitos ela havia se servido. E, ao mesmo tempo, eu tentei recuperar o solo histórico sobre o qual tudo isso havia sido feito, quer dizer, as práticas de internamento, a mudança nas condições sociais e econômicas no século XVII. Depois, em As palavras e as coisas, eu tentei retomar o problema, mas retomar o problema do próprio discurso científico, sem considerar o contexto histórico no qual ele havia se dado; em As palavras e as coisas, a análise é essencialmente uma análise das coisas ditas, das regras de formação das coisas ditas. ${ }^{55}$

Dois anos depois, em entrevista publicada na revista italiana Il Contributo, Foucault voltaria a falar de As palavras e as coisas: "um livro muito técnico, que se dirigia sobretudo aos técnicos da história das ciências. Eu o escrevi após discussões com Georges Canguilhem e esperava me dirigir essencialmente aos pesquisadores [em história das ciências]" ${ }^{, 56}$. De fato, os três livros de história das ciências escritos por Foucault na década de 60 - História da loucura na idade clássica (1961), Nascimento da clínica (1963) e As palavras e as coisas (1966) - revelam ao leitor a presença das lições de Canguilhem, como o próprio Foucault esclareceu em A arqueologia do saber (1969). Para Foucault, as análises de Canguilhem, marcadas pela descontinuidade, pelo reconhecimento de temporalidades múltiplas, pelo problema dos deslocamentos e transformações dos conceitos e pela nova maneira de relacionar as escalas micro e macroscópicas, caracterizavam um novo modelo de

\footnotetext{
${ }^{55}$ FOUCAULT, "La scène de la philosophie”, p. 583.

${ }^{56}$ FOUCAULT, “Entretien avec Michel Foucault”, p. 886.
} 
43

história das ciências: "trata-se de uma história epistemológica das ciências",57.

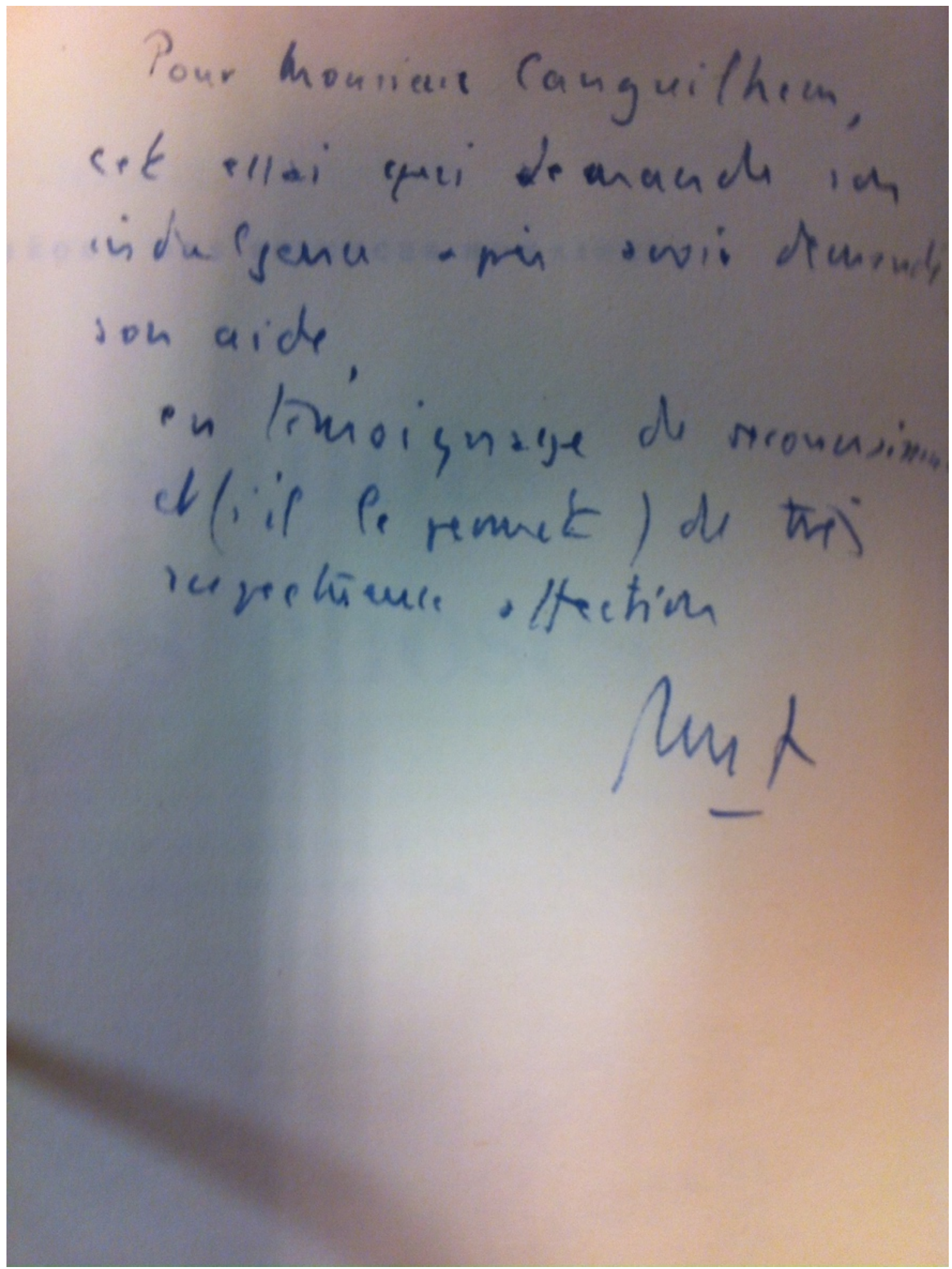

Fig. 1: Dedicatória escrita por Foucault no livro Les mots et les choses pertencente à biblioteca pessoal de Canguilhem. O texto diz: "Para o Sr. Georges Canguilhem, esse ensaio que solicita sua indulgência, depois de haver solicitado sua ajuda. Em testemunho de reconhecimento e (se permite) de muito respeitosa afeição. MF"

${ }^{57}$ FOUCAULT, A arqueologia do saber, p. 213. 
44

Pour houricur Georger rauguilhen cet ellai qui Pui doit hut, e) Jabard Janoir excite. vour Pu, dir loute und reconnsilicuce

put.

Fig. 2: Dedicatória escrita por Foucault no livro Archéologie du savoir pertencente à biblioteca pessoal de Canguilhem. O texto diz: "Para o Sr. Georges Canguilhem, esse ensaio que the deve tudo, em primeiro lugar ter-lhe motivado. Para lhe dizer todo meu reconhecimento. MF' 
No final daquela década cujo foco principal de seus trabalhos tinha sido a história das ciências, Foucault chamou a atenção para uma "mutação epistemológica da história",58, a partir do entrecruzamento das diferentes concepções de temporalidade dos objetos históricos dos Annales e da epistemologia francesa. Esse diagnóstico é feito de maneira preliminar, nas primeiras páginas de Arqueologia, "para revelar os princípios e as consequências de uma transformação autóctone em vias de se realizar no domínio do saber histórico" ${ }^{, 59}$. Assim, incluía seu trabalho na continuidade dessa transformação, e fazia do seu livro um exercício de "método de análise histórica"60. Em fevereiro de 1984, quatro meses antes da morte de Foucault, a revista francesa Le Matin publicou uma entrevista intitulada "Le style de l'histoire", o estilo da história. Nessa entrevista, onde os temas predominantes são a obra de Philippe Ariès, morto naquele mesmo mês, e a concepção de história dos Annales, Foucault falou sobre as relações entre saber e poder na historiografia, e lamentou que o diálogo entre as duas principais tendências historiográficas francesas do século XX tenha iniciado tão tardiamente:

Não é verdade que em uma sociedade existem as pessoas que tem o poder, e abaixo as pessoas que não tem qualquer poder. O poder deve ser analisado em termos de relações complexas e móveis, onde todas as pessoas não ocupam a mesma posição, e não mantêm sempre a mesma posição. É assim também para o pensamento. Não existe, por exemplo, de um lado o saber médico a ser estudado em termos de história do pensamento e, abaixo, o comportamento dos doentes, que seria assunto da etnologia histórica.

Nos últimos vinte anos, parece-me que o objeto da história muda. Desde o fim do século XIX até 1960, mais ou menos, a sociedade era o objeto fundamental da história. Tudo aquilo que não podia ser considerado como análise de uma sociedade não era história. Chama a atenção que os Annales não tenham falado dos historiadores franceses das ciências como Bachelard e Canguilhem, pelo menos não antes de 1970. [O que Bachelard e Canguilhem faziam] não era história porque não era história social. Fazer a história do recrutamento da população de médicos, isso é história, mas as próprias transformações do conceito de normal, isso não era. E, no entanto, essas transformações tiveram efeitos não-negligenciáveis sobre as práticas médicas, portanto, sobre a saúde das populações. É preciso lembrar, com Max Weber, que a racionalidade não é apenas o produto de uma sociedade, mas um fator constitutivo da história dos homens. ${ }^{61}$

Dois meses depois, em abril de 1984, Foucault enviou à Revue de métaphysique et

\footnotetext{
${ }^{58}$ FOUCAULT, A arqueologia do saber, p. 13.

${ }^{59}$ Ibidem, p. 17.

${ }^{60}$ Ibidem, p. 18.

${ }^{61}$ FOUCAULT, “Le style de l'histoire”, p. 1473-1474.
} 
de morale o artigo "La vie: l'expérience et la science", para publicação no número especial dedicado à obra de Canguilhem planejado para o ano seguinte. É o último texto assinado por Foucault, morto em junho daquele ano. Embora pretendesse submeter um texto inédito, Foucault teve forças apenas para enviar uma versão modificada da introdução escrita para a tradução estadunidense de $O$ normal e o patológico, publicada em 1978. Para Camille Limoges, após os textos de Macherey e de Lecourt, foi esse texto de Foucault que associou, de maneira duradoura, o nome de Georges Canguilhem à história das ciências. Novamente, Limoges denunciava essa interpretação como sendo o produto de um conhecimento limitado da obra de Canguilhem:

O artigo de Michel Foucault, "A vida: a experiência e a ciência", se apoiava nos textos de Canguilhem até 1977, mas nenhum daqueles anteriores ao Ensaio de 1943. Mas, sobretudo, desse artigo mais complexo do que a maioria de seus ecos levava a pensar, em geral seus leitores retiveram apenas uma parcela, as primeiras páginas caracterizando Canguilhem como o autor de uma "obra austera, voluntariamente bem delimitada e cuidadosamente dedicada a um domínio particular em uma história das ciências, que, de toda maneira, não é uma disciplina dada a grandes espetáculos" ${ }^{\text {"2 }}$

Em nota de rodapé, Limoges afirma que a frase de Foucault que mais chamou a atenção dos leitores viria a seguir:

\begin{abstract}
Suprimam Canguilhem e vocês não compreenderão mais grande coisa de toda uma série de discussões que ocorreram entre os marxistas franceses; vocês não mais apreenderão o que há de específico em sociólogos como Bourdieu, Castel, Passeron, e que os marca tão intensamente no campo da sociologia; vocês negligenciarão todo um aspecto do trabalho teórico feito pelos psicanalistas, especialmente os lacanianos. Mais: em todo o debate de ideias que precedeu ou sucedeu o movimento de 1968, é fácil reencontrar o lugar daqueles que, direta ou indiretamente, haviam sido formados por Canguilhem. ${ }^{63}$
\end{abstract}

Sem dúvida é uma passagem impressionante, frequentemente utilizada como prova de uma importância longe de ser unanimemente reconhecida a Canguilhem e justificar pesquisas universitárias sobre a sua obra. Mas Limoges, ainda empenhado em desfazer a imagem do Canguilhem-historiador, empobrece o debate ao afirmar que essa passagem ou aquela caracterização são os trechos do artigo de Foucault que mais chamaram a atenção dos

\footnotetext{
${ }^{62}$ LIMOGES, "L'épistémologie historique dans l'itinéraire intellectuel de Georges Canguilhem”, p. 54.

${ }^{63}$ FOUCAULT, “A vida: a experiência e a ciência", p. 353.
} 
seus leitores. Na verdade, nesse texto, Foucault sintetizou de maneira mais clara que qualquer outro autor o que foi a história da filosofia na França no século XX:

Sem desconhecer as dissensões que puderam, durante esses últimos anos e
desde o final da guerra, opor marxistas e não-marxistas, freudianos e não-
freudianos, especialistas de uma disciplina e filósofos, universitários e não-
universitários, teóricos e políticos, me parece que se poderia reencontrar uma
outra linha divisória que atravessa todas essas oposições. É a que separa uma
filosofia da experiência, do sentido, do sujeito e uma filosofia do saber, da
racionalidade e do conceito. De um lado, uma filiação que é a de Sartre e
Merleau-Ponty; e depois uma outra, a de Cavaillès, Bachelard, Koyré e
Canguilhem.

Essa interpretação de Foucault se tornou "canônica" na historiografia filosófica francesa. Em 2004, um colóquio na Université de Lille III convidou filósofos franceses para discutir a pertinência dessa bifurcação, o significado e a função de uma filosofia do conceito nos autores listados, mas notadamente nas obras de Cavaillès, Canguilhem e Foucault, e, por fim, a vitalidade dessa separação. Suas atas foram publicadas, pouco tempo depois, pela editora J. Vrin, sob o título Le concept, le sujet et la science: Cavaillès, Canguilhem, Foucault, reunindo contribuições de importantes pesquisadores franceses e estrangeiros, como Pierre Macherey, Guillaume Le Blanc, Frédéric Fruteau de Laclos e Frédéric Worms. De nossa parte, como se trata, nesse capítulo, de investigar o processo de construção da imagem de Canguilhem enquanto historiador "por natureza", nos deteremos no próprio texto de Foucault, destacando as implicações propostas entre a história das ciências e uma filosofia do saber, da racionalidade e do conceito. Esse problema específico abre o caminho para a retomada, mas também para a revisão, de algumas teses que propostas em um trabalho anterior, a dissertação de mestrado Aventuras e estratégias da razão: sobre a história epistemológica das ciências, cujo objetivo era afirmar a filiação Bachelard-CanguilhemFoucault em história das ciências a partir do problema da Filosofia Crítica, em sua vertente nietzschiana. Queremos crer que já está bastante claro para a historiografia científica contemporânea que as demandas feitas à história das ciências pelos principais programas elaborados desde a segunda metade do século passado dependem da posição assumida pelo historiador em relação aos debates filosóficos sobre a Modernidade, sobre a História como princípio de inteligibilidade e sobre o caráter emancipatório da Razão.

Para Foucault, o que permite a aproximação entre Bachelard e Canguilhem é o

${ }^{64}$ Idem. 
modo como eles tratam a questão da Aufklarüng ${ }^{65}$ - "essencial para a filosofia contemporânea" - no interior de sua História das Ciências, isto é, o fato de que fazem da História das Ciências o exame de uma razão "cuja autonomia de estrutura traz consigo a história dos dogmatismos e dos despotismos - consequentemente, uma razão que só tem efeito de libertação desde que ela consiga libertar-se de si mesma". ${ }^{66}$ Tal interpretação pode parecer conflitante à primeira vista com o que expusemos até aqui acerca da consciência histórica de Canguilhem, já que ele mesmo tratou de rejeitar Positivismo e Aufklärung num único movimento, afirmando que o rebaixamento da história das ciências ao papel de mera curiosidade filosófica, como de fato faziam alguns de seus contemporâneos, supunha "uma concepção dogmática da ciência e, se ousamos dizer, uma concepção dogmática da crítica científica, uma concepção dos 'progressos do espírito humano' que é a concepção da Aufklärung, de Condorcet e de Comte". ${ }^{67}$ Mas a contradição se dissolve quando entendemos que o sentido da filiação proposta por Foucault entre história das ciências e Aufklärung é o de um êthos. Basta colocar lado a lado dois textos onde essa articulação é proposta, começando por “O que são as Luzes?”, de 1984:

Gostaria, por um lado, de enfatizar o enraizamento na Aufklärung de um tipo de interrogação filosófica que problematiza simultaneamente a relação com o presente, o modo de ser histórico e a constituição de si próprio como sujeito autônomo; gostaria de enfatizar, por outro lado, que o fio que nos pode atar dessa maneira à Aufklärung não é a fidelidade aos elementos da doutrina [kantiana], mas, antes, a reativação permanente de uma atitude; ou seja, um êthos filosófico que seria possível caracterizar como crítica permanente do nosso ser histórico. ${ }^{68}$

Em seguida, o próprio artigo "A Vida: a Experiência e a Ciência":

A história das ciências deve sua dignidade filosófica ao fato de ela colocar em ação um dos temas que foi introduzido, de maneira sem dúvida um pouco sub-reptícia e como por acidente, na filosofia do século XVIII. Pela primeira vez, nessa época, questionou-se o pensamento racional não somente sobre sua natureza, seu fundamento, seus poderes e direitos, mas sobre sua história e sua geografia, sobre seu passado imediato e suas condições de

\footnotetext{
${ }^{65}$ Muito embora existam palavras em francês e inglês para traduzir Aufklärung - Lumières e Enlightenment, respectivamente - é bastante comum, entre os autores citados aqui, o uso do termo em alemão, certamente para evidenciar a relação com o texto escrito por Kant, em 1784, como resposta à pergunta “Was ist Aufklärung?" - "O que é o Iluminismo?" ou "O que é o Esclarecimento?". Pela mesma razão, optamos também por Aufklärung.

${ }^{66}$ FOUCAULT, "A Vida: a Experiência e a Ciência”, p. 357. Grifo nosso.

${ }^{67}$ CANGUILHEM, "La théorie cellulaire", p. 44.

${ }^{68}$ FOUCAULT, “O que são as Luzes?”, p. 344-345.
} 
exercício, sobre seu momento, lugar e atualidade. Dessa questão pela qual a filosofia fez, de sua forma presente e de sua ligação com seu contexto, uma interrogação essencial, pode-se tomar como símbolo o debate associado à Berlinische Monatsschrift e que tinha por tema: Was ist Aufklärung? ${ }^{69}$

Kant, argumenta Foucault, coloca a questão da Aufklärung de uma maneira completamente diferente dos outros filósofos que se impuseram a tarefa de refletir sobre seu próprio presente: "nem uma época do mundo à qual se pertence, nem um acontecimento do qual se percebe os sinais, nem a aurora de uma realização. Kant define a Aufklärung de uma maneira quase inteiramente negativa." A Aufklärung é definida negativamente como uma "saída" do estado de menoridade em que nos encontramos voluntariamente, por aceitarmos a autoridade de outros em matérias em que deveríamos fazer uso da nossa própria razão, permitindo, graças a esse uso ilegítimo da razão, o surgimento da ilusão e do dogmatismo. Saída, segundo Foucault, que não deixa de ser ambígua, pois sua divisa "aude saper", significa que a Aufklärung deve ser entendida ao mesmo tempo como um processo em vias de se desenrolar, mas também como uma tarefa, uma obrigação pessoal num processo coletivo. Ora, se Aufklärung é um ato de coragem, "é precisamente neste momento que a Crítica é necessária, já que ela tem o papel de definir as condições nas quais o uso da razão é legítimo para determinar o que se pode conhecer, o que é preciso fazer e o que é permitido esperar", explica Foucault.

Foucault define a modernidade como um êthos, uma atitude, "um modo de relação que concerne à atualidade". Dessa forma, mais que “o período moderno", nós devemos buscar compreender o que seria "a atitude de modernidade", pois é essa atitude, muito mais que a "fidelidade aos elementos da doutrina" kantiana que permitem a identificação de um projeto crítico. E a principal característica dessa atitude é a reflexão sobre a atualidade como diferença na história, que, por um lado, permite o surgimento de uma "consciência da descontinuidade do tempo: ruptura da tradição, sentimento de novidade, vertigem do que se passa” e, por outro, "determina um modo de relação que é preciso estabelecer consigo mesmo", diz Foucault. "Ser moderno não é aceitar a si mesmo tal como se é no fluxo dos momentos que passam; é tomar a si mesmo como objeto de uma elaboração complexa e dura". Para Foucault, é essa forma de problematização histórica do nosso ser no presente que torna possíveis tanto a leitura da filosofia no contexto de uma história geral, quanto a sua interpretação como princípio de inteligibilidade histórica. Assim, o "momento presente", se

\footnotetext{
${ }^{69}$ FOUCAULT, “A Vida: a Experiência e a Ciência”, p. 357. Grifo nosso.
} 
torna uma interrogação filosófica, e "a história se transforma, então, em um dos maiores problemas da filosofia" ${ }^{, 70}$.

No texto sobre Canguilhem, Foucault argumenta que a Aufklärung aparece sob diferentes formas em diferentes tradições filosóficas. Assim, por exemplo, enquanto a Alemanha deu-lhe corpo a partir de uma reflexão histórica e política sobre a sociedade, "na França, é sobretudo a história das ciências que serviu de suporte para a questão filosófica sobre o que tinha sido a Aufklärung" ${ }^{\text {"71 }}$. Para Foucault, temas como a relação entre saber e crença, conhecimento científico e senso comum, passagem do pré-científico ao científico são formas de elaboração do problema das Luzes no interior da reflexão filosófica e histórica sobre as ciências na França. E, para Foucault, aquela "filosofia do saber, da racionalidade e do conceito" que caracteriza a filiação de Koyré, Bachelard, Cavaillès e Canguilhem são diferentes facetas da questão da Aufklärung. Porém, e eis aqui a diferença fundamental, essa história das ciências não pretende fazer o elogio ou sequer a justificativa dessa racionalidade. Diferentes processos históricos ocorridos no século $\mathrm{XX}$ - o papel da ciência e da técnica do desenvolvimento das forças produtivas ou os efeitos de dominação que, em nome da ciência e da técnica, o Ocidente outorgou-se em relação a outras culturas - fizeram com que, na obra dos historiadores das ciências franceses, tratasse-se, segundo Foucault, de problematizar uma racionalidade que "pretende ao universal desenvolvendo-se inteiramente na contingência", que "valida a si mesma através de sua própria soberania" e, consequentemente, "traz consigo a história dos dogmatismos e dos despotismos"

Nesse cenário, não parece estranho, para Foucault, que a luz de Canguilhem tenha brilhado mais forte. Pois, ao fazer com que a história das ciências "descesse" dos domínios de grande formalização aos quais ela tradicionalmente se dedicou, como a Física ou a Matemática, intimamente relacionados à própria história da filosofia (pensemos, por exemplo, na mecânica galileana, na física newtoniana ou no cálculo de Leibniz), Canguilhem permitiu que se colocasse com mais clareza a relação entre história das ciências e filosofia. Ao fazê-lo, Canguilhem, segundo Foucault, teria não apenas aumentado o campo de abrangência da história das ciências, mas remanejado as tarefas da própria disciplina, num momento em que ela ainda brigava para afirmar sua autonomia em relação à filosofia universitária.

De fato, o pesquisador que volta sua atenção para os cursos de filosofia ministrados por Canguilhem a partir de 1941 na Faculté des Lettres de Strasbourg percebe o

\footnotetext{
${ }^{70}$ FOUCAULT, “A vida: a experiência e a ciência”, p. 355.

${ }^{71}$ Ibidem, p. 356.

${ }^{72}$ FOUCAULT, “A vida: a experiência e a ciência”, p. 357.
} 
crescente interesse pela teoria do conhecimento e pela história das ciências e das técnicas. Nas suas anotações para as aulas, a reflexão sobre o problema geral da história da filosofia é animada por um conjunto de questões particulares que o acompanhará ao longo da década: 1) Qual é a relação entre a filosofia e a história da filosofia?; 2) Qual é a relação entre a história da filosofia e a história das ciências?; 3) Qual é a relação entre a história das ciências e a história das ideias?. Num manuscrito datado de 1945, intitulado "Histoire de la philosophie et histoire des sciences", uma espécie de exercício pessoal, Canguilhem se pergunta: "Podemos dar uma definição a priori da filosofia, independente da sua história?". A negativa é elaborada através do tema da "historicidade", quer dizer, o fato de que a história de uma atividade é constitutiva da forma dessa atividade: "Se não podemos separar a filosofia da sua história, a definição do conceito de filosofia depende da sua história". A resposta levanta o problema da delimitação do domínio: “O que fazemos entrar nessa história?”, escreveu. O problema, ele continua, é que a filosofia não tem um objeto especial, constatação que o leva à reafirmação da famosa fórmula inscrita no Ensaio, de 1943: "A filosofia é uma reflexão para a qual toda matéria estrangeira é boa, e diríamos de bom grado, para a qual toda boa matéria deve ser estrangeira". Assim, Canguilhem propõe que a melhor solução para o filósofo é estender a ideia de uma "história constitutiva" da filosofia às "outras funções da consciência humana: religião, técnica, arte, ciência..." ${ }^{, 73}$.

A sequência do texto de Foucault é para mostrar que a novidade trazida por Canguilhem para a história das ciências, a originalidade na sua abordagem e na escolha dos seus objetos, correspondem às exigências impostas por essa "atitude de modernidade" que caracterizaria a epistemologia francesa. Para Foucault, Canguilhem teria remanejado a história das ciências em relação a um determinado número de pontos essenciais, sendo o primeiro justamente o tema da "descontinuidade". Trata-se, na verdade, de um tema caro

\footnotetext{
${ }^{73}$ CANGUILHEM, "Histoire de la philosophie et histoire des sciences", ff. 1-3, passim. Além daquela pergunta sobre a possibilidade de uma definição a priori da filosofia, Canguilhem levanta outros dois problemas: 1) "A história da filosofia deve utilizar o método geral da história naquilo que diz respeito ao estabelecimento do documento ou do texto. Trabalho preparatório: uma vez o documento datado/situado e estabelecido, resta interpretá-lo"; 2) "A história da filosofia é a história daquilo que está morto, perimido, desaparecido ou daquilo que é vivo? (...) História das doutrinas ou história dos problemas". Canguilhem propôs que a atualidade vem do observador, e não da obra em si. Em seguida, anotou que essa questão deveria ser relacionada ao "problema mais original do valor das ciências históricas. $C f$. Nietzsche e Aron". Anexo ao manuscrito, havia um documento datilografado, longo trecho da intervenção de Alexandre Koyré no debate "Sur la notion d'histoire de la philosophie" (do qual participaram também Léon Robin, Henry Berr, Jean Wahl e Leon Brunschvicg), publicado no Bulletin de la Société française de Philosophie em junho de 1936. Nesse debate, Koyré defendeu que a história da filosofia é uma história do presente.
} 
àquela filiação do saber, da racionalidade e do conceito. Foi no livro Ensaio sobre o conhecimento aproximado, de 1928, que Bachelard introduziu os conceitos inteiramente novos que lhe garantiram lugar de destaque - fala-se dele como um limiar - nas investigações sobre as bases filosóficas do pensamento contemporâneo. Segundo Bachelard, é possível verificar que na "evolução histórica de um problema específico aparecem verdadeiras rupturas, mutações bruscas, que derrubam a tese da continuidade epistemológica"74. A ruptura, tornada categoria epistemológica por Bachelard, representa as descontinuidades no desenvolvimento histórico das ciências, quando um tremor conceitual nos obriga a uma reformulação dos nossos conhecimentos e do próprio modo como conhecemos.

Quando, mais de uma década depois, Alexandre Koyré deu início à sua carreira como historiador das ciências, após anos de pesquisas dedicadas à História da Filosofia e à Filosofia da Religião, abriu o livro Études Galiléennes, de 1939, falando de uma ruptura, a "revolução científica do século XVII" - expressão e objeto consagrados pelos historiadores profissionais desde então - "uma verdadeira mutação do intelecto humano (...). Uma das mais importantes, se não a mais importante desde a invenção do Cosmos pelo pensamento Grego" ${ }^{, 75}$. Koyré explica que tomou de Bachelard, sobretudo do Novo Espírito Científico, de 1934, e de A formação do espírito científico, de 1938, a noção e o termo de mutação intelectual, para designar "uma espécie de virada total da atitude espiritual". Anos mais tarde, em Do mundo fechado ao universo infinito, de 1957, Koyré explicou que seu objetivo nos Études Galiléenes era "definir os esquemas estruturais da antiga e da nova concepção do mundo e descrever as mudanças produzidas pela revolução do século XVII"76.

\footnotetext{
${ }^{74}$ BACHELARD, Ensaio sobre o conhecimento aproximado, p. 271.

${ }^{75}$ KOYRÉ, Etudes Galiléenes, p. 05-06.

${ }^{76}$ KOYRÉ, Du monde clos à l'univers infinit, p. 11. Sabemos que a "ruptura" bachelardiana obteve sucesso imediato na França, mas também podemos encontrar, a partir dos trabalhos de Koyré, indícios para explicar a recepção tardia desse conceito e seus correlatos de descontinuidade nos países de língua inglesa. Foi no prefácio ao livro The Structure of the Scientific Revolutions, publicado em 1962, que Thomas Kuhn reconheceu seus débitos com certos historiadores franceses para a formação da sua concepção de uma história das ideias científicas: Émile Meyerson, Hèlene Metzger e, com maior dedicação de leitura, Alexandre Koyré e seus "Études Galiléennes", cuja "importância é secundária somente quando comparada com os materiais provenientes de fontes primárias" (KUHN, A Estrutura das Revoluções Cientificas, p 10-11). Kuhn também se refere a Anneliese Maier e Arthur O. Lovejoy, com seu Great Chain of Being. Ver também: GUTTING, "Thomas Kuhn and the French philosophy of science", p. 56: "The one movement in twentieth-century European thought that has substantive affinities with Kuhn's work is the French tradition of philosophy of science. This begins with the classic writings of Poincaré, Duhem, and Meyerson but takes on its distinctive character (and its strongest similarities to Kuhn) in the work of Léon Brunschvicg, Gaston Bachelard, and Georges Canguilhem. Kuhn himself, unfortunately, had only a glancing contact with this tradition and no serious understanding of it. The main contact came through Koyré, who had urged him to meet Bachelard and provided a letter of introduction.
} 
É fácil compreender porque Foucault identificou uma "mutação epistemológica na história" a partir do tema da descontinuidade. Não que ela não existisse, isto é, não fosse percebida pelos historiadores; o que Bachelard, Koyré e Canguilhem fizeram foi alterar o seu estatuto. A descontinuidade aparecia apenas como acidente, ou algo que deveria ser suprimido pelo historiador, que tinha a tarefa de reencontrar a unidade sob a dispersão temporal provocada, digamos, por uma descoberta. Com Bachelard e Koyré, a descontinuidade deixou de ser um acontecimento impensado que desafiava o historiador a situá-lo num percurso ininterrupto para tornar-se, ao mesmo tempo, uma operação deliberada do historiador e o resultado da sua descrição, ou seja, "ela é, ao mesmo tempo, instrumento e objeto de pesquisa, já que delimita o campo de uma análise da qual ela é o efeito",77. Mas, falando especificamente sobre Canguilhem, Foucault pondera que:

Retomando esse mesmo tema elaborado por Koyré e por Bachelard, Georges Canguilhem insiste no fato de que a identificação das descontinuidades não é, para ele, nem um postulado, nem um resultado; é, antes, uma "maneira de fazer", um procedimento que se integrou à história das ciências, porque ele é requisitado pelo próprio objeto do qual ela deve tratar. A história das ciências não é a história do verdadeiro, da sua lenta epifania; ela não poderia pretender relatar a descoberta progressiva de uma verdade inscrita desde sempre nas coisas e no intelecto, salvo se se pensasse que o saber atual possui finalmente de maneira tão completa e definitiva de que ele pode usála como um padrão para mensurar o passado. ${ }^{78}$

Porém, continua Foucault, apesar dessa compreensão de Canguilhem sobre o inacabamento essencial do objeto da história das ciências, que interdita que se tome a forma atual de qualquer ciência como sua forma definitiva (mesmo nas Matemáticas, que parecem tão seguras de seu curso), isso não faz da história das ciências uma "pura e simples história das ideias e das condições em que elas surgiram antes de se apagarem" ${ }^{\text {,79. }}$.

Na história das ciências [tal como praticada por Canguilhem], não se pode conceber a verdade como adquirida, mas tampouco se pode fazer a economia de uma relação com o verdadeiro e da oposição do verdadeiro e do falso. É essa referência à ordem do verdadeiro e do falso que dá a essa história sua especificidade e sua importância. De que forma? Concebendo que ela se relaciona com os discursos que se retificam, se corrigem, e que operam em si

The upshot, as Kuhn tells the story, was more a comedy of errors than a meeting of great minds."

${ }^{77}$ FOUCAULT, "Sobre a arqueologia das ciências. Resposta ao Círculo de Epistemologia", p. 84-85.

${ }^{78}$ FOUCAULT, “A vida: a experiência e a ciência”, p. 358-359.

${ }^{79}$ Ibidem, p. 359. 
mesmos todo um trabalho de elaboração pela tarefa do "dizer verdadeiro"

É essa tarefa do "dizer verdadeiro" das ciências, tarefa que o historiador das ciências não pode jamais negligenciar, que engendra o segundo tema em torno do qual, segundo Foucault, Canguilhem remanejou a história das ciências: "Quem diz 'história do discurso verídico' diz também método recorrente" ${ }^{\text {81 }}$. Em 1951, no livro L'activité rationaliste de la physique contemporaine, Bachelard apresentou a noção epistemológica de recorrência a partir de uma história dupla: a "história sancionada" (ou história do que há de científico na prática científica) e a "história perimida" (ou história das intervenções do não-científico na prática científica). Bachelard cita como exemplo de uma história recorrente as investigações sobre os trabalhos do físico e químico escocês Joseph Black, cuja teoria do calor latente, apesar das várias revisões desde o século XVIII, foi determinante para a elaboração do conceito de calores específicos, tão caro à Física e à Química contemporâneas. E é esse valor dos calores específicos para a ciência contemporânea que torna necessário o "interesse constante em conhecê-los teoricamente, em elucidá-los epistemologicamente, em seguir sua incorporação num conceito de elementos racionalizados" em imprimir-lhes, portanto, uma história sancionada na qual Black ocuparia seu lugar. "Bem entendida, essa história recorrente, essa história julgada, essa história valorizada não pode nem quer restabelecer as mentalidades pré-científicas", afirmou Bachelard. A história recorrente, ele prossegue, "é feita sobretudo para ajudar a tomar consciência da força de certas barragens que o passado do pensamento científico formou contra o irracionalismo" $" 82$. Em outras palavras:

Devemos, então, compreender a importância de uma dialética histórica própria ao pensamento científico. Em suma, é preciso formar e reformar incessantemente a dialética da história perimida e da história sancionada pela ciência atualmente ativa. A história da teoria do flogístico é perimida porque repousa sobre um erro fundamental, sobre uma contradição da química ponderal. Um racionalista não pode se interessar por ela sem uma má consciência. Um epistemólogo só se interessa por ela porque encontra aí motivos para a psicanálise do conhecimento objetivo. Um historiador das ciências que se compraz com isso deve saber que trabalha na paleontologia de um espírito científico desaparecido. Ele não pode esperar ter uma ação sobre a pedagogia das ciências de nosso tempo. ${ }^{83}$

Tal perspectiva impõe não apenas novas tarefas e novas abordagens para a história

\footnotetext{
${ }^{80}$ Idem.

${ }^{81}$ Idem.

${ }^{82}$ BACHELARD, L'activité rationaliste de la physique contemporaine, p. 27.

${ }^{83}$ Ibidem, p. 25.
} 
das ciências, mas também novas fontes. "A história das ciências não pode ser simplesmente uma história de registros", explicou Bachelard. "As atas das academias contêm naturalmente numerosos documentos para a história das ciências. Mas estas atas não constituem verdadeiramente uma história das ciências". ${ }^{84}$ Essa história de registros, que narra descobertas e coleciona nomes e datas, por não dar conta da especificidade do pensamento científico, não percebe que o progresso das ciências, na opinião de Bachelard, é um progresso racional, marcado pelo aprofundamento da coerência entre as verdades científicas, ou seja, não percebe que "o eixo central da história das ciências é claramente dirigido no sentido de uma compreensão melhorada e de uma experiência alargada". ${ }^{85}$ Bachelard acrescenta: "para dizer tudo o que penso, creio que a história das ciências não pode ser uma história empírica" ${ }^{\text {" }}$. E como, apesar de todo desenvolvimento, de todo progresso nas ciências, os grandes mitos do imaginário e complexos do inconsciente podem retornar a qualquer momento à prática científica, pois fazem parte do "espírito" do cientista e, nessa qualidade, se sobrepõe ao seu discurso, Bachelard considerou que era preciso atribuir à história das ciências uma função maior que a mera descrição daqueles progressos: a função de um tribunal. Mais que uma história julgada a partir das conquistas técnicas de uma determinada sociedade, a história das ciências deve se apresentar, nas palavras de Bachelard, como uma "história intelectual julgada". 87

Essa perspectiva do progresso científico problematiza o tempo da História das Ciências, pois, segundo Bachelard, se "a temporalidade da ciência é um crescimento do número das verdades, um aprofundamento da coerência das verdades" e a "história das ciências é a narrativa deste crescimento, deste aprofundamento" ${ }^{\prime \prime 8}$, o historiador que pretender escrever de fato a história positiva de uma ciência deverá situar-se na modernidade dos seus conhecimentos, para identificar, no passado, o que realmente pertence à sua história e o que há de nocivo e fecundo no seu desenvolvimento. Para a História das Ciências recorrente tal como elaborada por Bachelard, a consciência de modernidade e a consciência de historicidade seriam, portanto, rigorosamente proporcionais. Foucault argumenta, com razão, que

\footnotetext{
${ }^{84}$ BACHELARD, L'actualité de l'histoire des sciences, p. 141-142.

${ }^{85}$ Ibidem, p. 140.

${ }^{86}$ Ibidem, p. 151.

${ }^{87} \mathrm{BACHELARD}$, Le matérialisme rationnel, p. 105: "Comme nous les disions dans notre dernier livre, L'activité rationaliste de la physique contemporaine, nous sommes conscients de notre histoire intellectuelle jugée, dès que nous formons notre savoir le long d'un progrès de la connaissance scientifique. En particulier, nous gardons la marque de toutes les révolutions de culture que nous devons réaliser en assimilant le savoir scientifique moderne."

${ }^{88}$ BACHELARD, "L'actualité de l'histoire des sciences", p. 148.
} 
Canguilhem possui uma compreensão distinta da recorrência. Canguilhem não vê a história das ciências como um aprofundamento da coerência das verdades, mas como passagem de uma coerência de verdade a outra. A recorrência, em Canguilhem, seria o reconhecimento de que "as transformações sucessivas desse discurso verídico produzem, ininterruptamente, remanejamentos em sua própria história”. Foucault segue explicando:

O que, por muito tempo, tinha se mantido como impasse se torna um dia solução; um experimento lateral se transforma em um problema central em torno do qual todos os outros passam a gravitar; um procedimento ligeiramente divergente tornar-se uma ruptura fundamental (...). Em suma, a história das descontinuidades não é adquirida de uma vez por todas; ela é "impermanente" por si mesma, ela é descontínua; deve ser ininterruptamente retomada através de novos esforços. ${ }^{89}$

Essa postura impõe uma dificuldade para o historiador das ciências. A atenção à atividade científica real é uma característica importante das pesquisas de Bachelard sobre a história e a filosofia das ciências. "O historiador das ciências, para bem julgar o passado, deve conhecer o presente; ele deve aprender o melhor possível a ciência da qual ele pretende escrever a história", prescreveu ${ }^{90}$. Mas isso quer dizer que, se a ciência faz e refaz constantemente a sua história, e é preciso estar atento a essas transformações para saber de que se deve escrever a história, apenas os cientistas estariam aptos a escrever a história daquilo que eles fazem e dizem? Muitos historiadores responderam positivamente a essa pergunta. Já no famoso livro de Lucien Febvre, Combats pour l'histoire, publicado em 1952, o pai-fundador dos Annales, à pergunta “Quem pode ser historiador das ciências?”, responde que apenas os cientistas possuem competência para o ofício, apenas "aqueles mesmos que estudaram as ideias científicas nas suas origens, nas suas expressões diversas e nas suas consequências". 91 Em 1978, Jacques Le Goff, com a colaboração de Jacques Revel e Roger Chartier, organizou a publicação de La Nouvelle Histoire. Nesse dicionário, encontramos o artigo de Jean-Marie Pesez, "História da Cultura Material”, em que ele coloca, para a História das Técnicas, um problema semelhante ao da História das Ciências: "Podemos nos perguntar se não há nisso [na rejeição da História das Técnicas pelos historiadores de ofício] como que uma confissão de impotência, se a técnica não assusta o historiador devido à alta especialização que requer".

\footnotetext{
${ }^{89}$ FOUCAULT, “A vida: a experiência e a ciência”, p. 360.

${ }^{90}$ BACHELARD, "L'actualité de l'histoire des sciences", p. 142.

${ }^{91}$ FEBVRE. Combats pour l'histoire, p. 336.
} 
A resposta é bastante clara: o que supera as capacidades de um só se torna possível fazer a muitos. É um problema de especialização e trabalho em equipe. Contudo, por causa das suas dificuldades, a história das técnicas não deve ser abandonada aos técnicos, como a história da filosofia o foi aos filósofos e a história das ciências aos cientistas. Se viesse a ser, a história não se reconheceria mais num discurso em que ela se reduziria a uma seca cronologia. ${ }^{92}$

Esse argumento de especialização é um velho conhecido dos historiadores das ciências - dos historiadores de formação dedicados às ciências - muito embora não seja aplicado tão frequentemente à história da arte, das religiões ou da literatura ${ }^{93}$. Apesar das décadas de distância e da mudança de atitude de Pesez em relação a Febvre, é fácil perceber que ambos compartilham a falta de clareza sobre as tarefas da história das ciências.

"Para Georges Canguilhem, o problema não é de profissão: é de ponto de vista", explica Foucault. "A história das ciências", ele continua, "não pode se contentar em reunir o que os cientistas do passado puderam pensar ou demonstrar". Mas, ao mesmo tempo, um dos pontos fundamentais do método de Canguilhem, ainda segundo Foucault, é que a história das ciências não se faz filtrando o trabalho de cientistas do passado a partir das teorias atualmente válidas com o objetivo de detectar a emergência do verdadeiro. "A história das ciências só pode se constituir no que ela tem de específico levando em conta, entre o puro historiador e o próprio cientista, o ponto de vista do epistemólogo". Assim, as objeções de Limoges ao texto de Foucault soam ainda mais estranhas que aquelas feitas aos textos de Macherey e Lecourt, pois no artigo "A vida: a experiência e a ciência", a história das ciências não é apresentada de modo algum como uma "primeira natureza" de Canguilhem. O que Foucault descreve é a figura de um filósofo que entende a ciência e a técnica como fatores constitutivos do homem e assume o problema da história das ciências para tematizar os dogmatismos e despotismos de uma razão constituída de modo contingente, mas que, enquanto racionalista, reconhece também o efeito de libertação da razão - "desde que ela consiga libertar-se de si mesma"94. Em suas próprias palavras, o que Foucault descreve é a figura de um "historiador das

\footnotetext{
${ }^{92}$ PESEZ, Jean-Marie, "História da Cultura Material”, p. 191. Percebe-se que a crítica também atinge a História Intelectual.

${ }^{93}$ Essa observação é tão comum quanto o argumento que a precede, mas aproveitamos a oportunidade para mencionar o artigo "La science, le continent ignoré des historiens français?", de Jérôme Lamy, um excelente apanhado de referências de historiadores franceses à história das ciências, de Lucien Febvre até 2003. Esse artigo começa com uma informação inquietante, não pela novidade, mas por sua tradução em números: segundo Lamy, o último Répertoire de l'histoire des sciences et des techiniques en France revelava que, dos quatrocentos e quarenta nomes listados como pesquisadores nessa área, apenas dezessete eram de historiadores profissionais.

${ }^{94}$ FOUCAULT, “A vida: a experiência e a ciência", p. 357.
} 
racionalidades" $" 95$.

Além disso, Foucault, ao defender a originalidade do método de Canguilhem no que diz respeito ao problema da história das ciências, deixa de fora aquele que nos parece ser um ponto central. A questão não é apenas de "ponto de vista" em relação ao trabalho dos cientistas: Canguilhem se esforçou para demonstrar que o objeto da história das ciências não é o mesmo objeto das ciências da qual se escreve a história. Essa preocupação de Canguilhem já pode ser sentida em 1943. Nos anos seguintes à publicação do Ensaio, a maior parte dos resenhistas se limitaram a ver exatamente aquilo que Canguilhem disse que o livro é: um estudo filosófico que toma por objeto uma matéria estrangeira, a medicina, para tratar de dois problemas humanos concretos, a relação entre as ciências e as técnicas e a relação entre o normal e as normas. Mas, em 1947, portanto quatro anos após a publicação da tese, Pierre Brunet publicou uma resenha do Ensaio no número inaugural da Revue d'Histoire des Sciences. "Não sendo um estudo histórico, esse trabalho, cuja primeira parte é inteiramente centrada em torno dos nomes de Comte e de Claude Bernard, é suscetível (...) de interessar aos historiadores das ciências", escreveu ${ }^{96}$.

Consideremos o lugar institucional dessa resenha, a Revue d'Histoire des Sciences, criada pelo próprio Brunet, a pedido de Henry Berr, como órgão oficial da Seção de História das Ciências do Centre de Synthèse. A publicação do primeiro número, em 1947, aconteceu num período de transição entre dois projetos do Centre de Synthèse, o projeto filosófico da primeira metade do século passado, quando se tratava de situar as ciências na história, e aquele que caracterizaria os anos 60 e 70 na França, a constituição da História das Ciências como campo disciplinar. Brunet, que acumulava as funções de diretor da Revue d'Histoire des Sciences e da Seção de História das Ciências do Centre de Synthèse, localizou no Ensaio de Canguilhem ideias relevantes para esses dois projetos.

Favorecendo o projeto disciplinar, Brunet viu na abordagem histórica de exemplos precisos retirados da físiologia e da patologia a confirmação de que "vários problemas científicos não se explicam verdadeiramente senão através da história das ciências, e que esta, consequentemente, está longe de possuir apenas um valor de simples curiosidade histórica" ${ }^{" 97}$. Esse foi o principal argumento mobilizado por Brunet em um texto programático publicado no número seguinte da mesma revista sob o título "L'Histoire des Sciences dans l'enseignement", dedicado à defesa da institucionalização da História das Ciências no ensino

\footnotetext{
${ }^{95}$ Ibidem, p. 365.

${ }^{96}$ BRUNET, "Essai sur quelques problèmes concernant le normal et le pathologique. Compte rendu", p. 90.

${ }^{97}$ BRUNET, Op. cit., p. 91.
} 
francês, dos liceus às universidades. Quanto ao projeto de inserção das ciências na história, questão de teoria das ciências tanto quando de teoria da história das ciências, Brunet afirmou ter encontrado no livro de Canguilhem "uma ideia interessante" que ele cita diretamente da primeira parte do Ensaio: "A história das ideias não pode ser necessariamente superposta à história das ciências", afirmou Canguilhem. "Porém, já que os cientistas, como homens, conduzem sua vida em um meio e em companhias não exclusivamente científicos, a história das ciências não pode negligenciar a história das ideias." 98

Mostraremos, no capítulo seguinte, que essa apreciação que os historiadores das ciências puderam fazer da tese de doutorado em medicina de Canguilhem na década de 40 está diretamente ligada à leitura de Sigerist por Canguilhem. Mostraremos que já na tese de 1943 vemos aparecer as primeiras formulações de uma técnica histórica própria às ciências da vida e à medicina, capaz de dar conta desses novos objetos inscritos por Aron no epíteto que atribuiu a Canguilhem: "Doutor em medicina, historiador do pensamento médico e biológico".

\footnotetext{
${ }^{98}$ CANGUILHEM, Essai sur quelques problèmes concernant le normal et le pathologique, p. 16. Apud BRUNET, loc. cit.
} 


\section{Capítulo 2 \\ História das ideias e história dos conceitos}

Uma das preocupações mais constantes nos manuscritos e nas anotações dos cursos e conferências de Canguilhem são as relações entre história da filosofia e história das ciências. É também uma das suas mais antigas preocupações, presente já na elaboração do Ensaio, de 1943, e também naquele artigo sobre a teoria celular, de 1946. Em 1948, Canguilhem se tornou Inspetor Geral de instrução pública, cargo que ocuparia até 1955, quando assumiu os dois postos vagos pela aposentadoria de Bachelard, na Sorbonne e no Institut d'histoire des sciences et des techniques. Esse período concentra esforços de diversos pesquisadores para inserção do ensino de história das ciências nas universidades e nos liceus. $\mathrm{O}$ argumento era o valor pedagógico da história das ciências, uma disciplina filosófica, para o ensino e para o progresso das ciências. Em 1947, os novos programas curriculares previam que o professor de física tratasse em sala de aula "da evolução das ideias sobre a energia, a luz, a constituição da matéria etc", uma norma que logo se aplicou às outras ciências. Para ajudar a adequar os professores à nova situação, Canguilhem organizou as Jornadas de informação para coordenação dos ensinos de Filosofia e de Ciências fisicas nas classes de Filosofia e de Ciências experimentais, realizadas em Estrasburgo em novembro de 1949. Nesse evento, Canguilhem apresentou uma conferência sobre "o papel da história das ciências na filosofia das ciências" a partir de um estudo de caso, "o estabelecimento dos fatos fundamentais da dinâmica". Eis a lição geral que Canguilhem esperava ter passado à sua audiência:

Nós pretendemos ter mostrado a partir de um exemplo que a história das ciências não é um passatempo para eruditos. Indispensável para dar ao ensino de ciências o sentido da conquista do saber, ela é capital em filosofia das ciências para the conservar o sentido da sua autonomia. Se a filosofia das ciências nada é senão o percurso, na sequência dos cientistas, das vias bem aplanadas, ela não tem nenhum interesse, posto que ela apenas serve de duplo. Mas uma metodologia autêntica não pode esquecer que método quer dizer "caminho em direção a" e um caminho não preexiste ao seu traçado. Do ponto de vista filosófico, são a ciência em sofrimento e a ciência militante, e não a ciência triunfante, que são interessantes (...). Saibamos mostrar aos nossos alunos, no mais humilde dos instrumentos do laboratório de física, da inteligência morta, que a inteligência viva ressuscita. Mas para isso tenhamos essa mesma probidade intelectual que nós dizemos ser a primeira virtude do cientista. A história das ciências não se inventa. Nós não substituímos a ignorância pela lenda.

Que demos pouco aos nossos alunos, mas demos exemplos simples, recolhidos nas melhores fontes e corretamente analisados. Nada de vulgarização fácil, nada 
de grandes quadros, nada de recapitular em meia hora de aula alguns séculos de história do pensamento. Não queremos o método da autoridade, não o usemos sequer no momento em que mostramos a nossos alunos o quanto foi difícil para o espírito humano se livrar dele. Constituamos pouco a pouco uma história das ciências cientificamente co-elaborada, nos assegurando da realidade do evento, da justeza da interpretação. Não se trata de retornar ao culto do fato. Em ciência como em política, o culto do fato é uma forma de barbárie (...). É preciso que a história das ciências que nós utilizamos na filosofia das ciências conserve um valor subordinado. É preciso constituí-la cientificamente para utilizá-la filosoficamente. É preciso constituí-la cientificamente para utilizá-la filosoficamente. Aqui também é necessária uma ideia diretiva, uma intenção de demonstração explícita. A história das ciências deve ser sustentada por uma filosofia das ciências e uma filosofia das ciências por uma teoria do conhecimento. ${ }^{1}$

Pouco tempo depois, em 1951, agora nas Jornadas de informação para coordenação dos ensinos de Filosofia e das Ciências naturais, realizadas no Centre international pédagogique de Sèvres, Canguilhem apresentou a conferência intitulada "L'Expérimentation em Biologie animale". Canguilhem criticou o fato de que os professores de biologia, tendo atribuído à Introduction à l'étude de la médecine expérimentale, de Claude Bernard, um valor equivalente em ciências da vida ao que o Discours de la méthode de Descartes tem para as ciências abstratas da matéria, transformaram em prática escolar corrente utilizar a Introduction da mesma maneira que se utiliza o Discours: "como paráfrase, como resumo, de comentário verbal, sem se dar ao trabalho de inserir um ou outro na história da biologia ou na história da matemática". 2 Canguilhem ainda criticou os professores de biologia - a quem se dirigia durante a conferência por terem mutilado a Introduction, reduzido sua utilização basicamente à primeira parte, "uma soma de generalidades, se não de banalidades, em curso nos laboratórios, esses salões do mundo científico". Para Canguilhem, o verdadeiro tesouro para o ensino contemporâneo das ciências biológicas estava na segunda e terceira parte do livro de Claude Bernard, que conteriam "a carta da experimentação em biologia". E mesmo quando utilizavam em sala de aula essas partes do livro, continua Canguilhem, os professores buscavam aqueles exemplos "de manual”, em vez dos "exemplos de experimentação propriamente heurística", a saber, aqueles que mostravam "a retificação de um erro", aqueles que permitiam exibir "o sentido e o valor dessa empreitada plena de riscos e de perigos que é a experimentação em biologia".

Para comprovar o valor da abordagem histórica no ensino da biologia experimental, Canguilhem parte de um exemplo corriqueiro, a demonstração da contração - definida como uma

\footnotetext{
${ }^{1}$ CANGUILHEM, "Rôle de l'histoire des sciences... ", p. 389-390.

${ }^{2}$ CANGUILHEM, "L'Expérimentation em Biologie animale", p. 17. Uma versão modificada dessa conferência foi publicada em $O$ conhecimento da vida.
} 
modificação da forma do músculo sem variação do volume - a partir do estímulo elétrico de um músculo isolado imerso num tubo repleto de água. O professor de biologia, diz Canguilhem, fica feliz com a demonstração do "fato" de que o músculo se contraiu sem que houvesse alteração do volume no tubo. Canguilhem não poupou críticas à miséria dessa prática pedagógica:

É um fato epistemológico que um fato experimental assim ensinado não possui nenhum sentido biológico. É assim porque é assim. Para dar um sentido a tal fato, é preciso remontar ao primeiro que teve a ideia de uma experiência desse tipo, quer dizer, remontar a Swammerdam (1637-1680) (...). Tratava-se, contra as teorias de origem galênica e estoica então dominantes, de mostrar que, na contração, o músculo não se aumentava de nenhuma substância. Isolado desse debate, preso numa pedagogia sem história, esse pretenso "fato" perde seu sentido real, em verdade histórica, para assumir um lugar nas mornas dissertações sobre o "método experimental" das quais se alimenta certa epistemologia dogmática. ${ }^{3}$

Assim, nesses textos de caráter pedagógico sobre a história das ciências escritos por Canguilhem antes de 1955, tratava-se de demonstrar que somente a história dá sentido aos problemas científicos, sejam eles das ciências naturais ou biológicas. E, por sua vez, tal história só poderia adquirir um sentido heurístico se fosse epistemologicamente orientada, isto é, buscada com um sentido de problema. Sem dúvida tal interpretação contribuiu para que, durante muito tempo, o tema da história das ciências na obra de Canguilhem fosse estudado como uma reflexão desenvolvida alheia ao trabalho dos historiadores profissionais. Mas a abertura dos seus arquivos e a publicação das suas obras completas começaram a mudar essa opinião.

Tendo obtido o reconhecimento do próprio Canguilhem pela judiciosa interpretação que propôs da sua teoria da história das ciências, na qual considerava os contextos de produção e de recepção, o espanhol Francisco Vázquez García destaca-se também entre os pesquisadores que, desde a abertura dos arquivos do CAPHÉS, tem se preocupado com as relações entre Canguilhem e os historiadores. Recentemente, apoiado em ampla documentação inédita, Vázquez García mostrou que Canguilhem foi um leitor atento de Marc Bloch, Lucien Febvre e Maurice Halbwachs desde 1931, quando não eram ainda identificados como a primeira geração dos Annales, mas como a "equipe de Estrasburgo", em referência à Faculté des Lettres de Strasbourg, onde desenvolviam suas pesquisas ${ }^{4}$.

A originalidade desse grupo vinha, primeiro, de uma concepção de história profundamente marcada pela geografia humana de Vidal de la Blache. Para Canguilhem, explicou Vázquez García, a história, tal como praticaram Febvre e Bloch, notadamente nos livros

\footnotetext{
${ }^{3}$ CANGUILHEM, "L’Expérimentation em Biologie animale”, p. 18-20, passim.

${ }^{4}$ GARCIA, "Senderos Encontrados: Canguilhem y la escuela de los Annales", p. 49.
} 
La terre et l'évolution humaine (1922) e Les caractères originaux de l'histoire rurale française (1931), e a geografia vidaliana eram as faces de uma mesma moeda. Além disso, para Canguilhem, o que distinguia a sociologia de Halbwachs em relação à de Durkheim era justamente a incorporação, pelo primeiro, do conceito vidaliano de "gêneros de vida"5. Outros elementos dessa aproximação, como a crítica ao determinismo do meio e a importância reconhecida à técnica, atraíam a atenção de Canguilhem. Entre as décadas de 30 e 60, representantes da escola vidaliana e da equipe de Estrasburgo foram constantemente citados por Canguilhem em seus escritos menos conhecidos, manuscritos e notas de cursos, a tal ponto que, para Vázquez García, é possível dizer que esse encontro entre geografia e história marcou profunda e definitivamente o estilo epistemológico de Georges Canguilhem. "A própria concepção do saber histórico que Canguilhem elaborou no final da década de 1930 é profundamente tributária dos fundadores dos Annales", afirmou ${ }^{6}$.

Debruçado sobre os manuscritos preservados no CAPHÉS, Vázquez García notou que, no final dos anos 30, Canguilhem listou na bibliografia geral dos seus cursos diversos artigos de Febvre, muito dos quais viriam a ser reunidos no livro Combats pour l'histoire (1952). Artigos dos fundadores dos Annales publicados na Revue de Synthèse eram usados por Canguilhem em suas aulas para fazer a crítica da historiografia tradicional, notadamente do papel que ela atribuía às "grandes personalidades" na explicação dos "grandes acontecimentos" da história, e da projeção da nossa experiência íntima da duração no tempo histórico, na verdade socialmente construído. Apoiado em notas de curso, outros manuscritos e em vasta documentação publicada no primeiro tomo das obras completas de Canguilhem, Vázquez García argumenta que a “coalização dos recursos intelectuais" resultante da leitura de Febvre e Bloch, das Considerações extemporâneas, de Nietzsche, e da Introduction à la philosophie de l'histoire, de Raymond Aron, permitiram que Canguilhem rejeitasse definitivamente tanto o "velho objetivismo histórico, de matriz rankeana", quanto a filosofia especulativa da história, "pecado de filósofo, tentação de historiador"7 . Segundo Vázquez García, foi também apoiado nas leituras de Bloch e Febvre que Canguilhem passou a denunciar o "vírus do precursor", símbolo máximo da ilusão retrospectiva que pretende que o presente já deveria estar contido em germe em toda reconstituição histórica.

\footnotetext{
${ }^{5}$ Em O normal e o patológico, Canguillhem afirma: "Na espécie humana, a frequência não traduz somente uma normatividade, mas uma normatividade social. Um traço humano não será normal porque frequente, mas frequente porque normal, quer dizer, normativo em um gênero de vida dado, tomando as palavras gênero de vida no sentido atribuído pelos geógrafos da escola de Vidal de la Blache." (In: Le normal et le patholgique, p. 102). Para mais informações sobre a obra de Vidal de la Blache, recomendamos o livro de Larissa Alves de Lira, O Mediterrianeo de Vidal de la Blache, publicado em 2013 pela Alameda Editorial.

${ }^{6}$ GARCIA, Loc. cit.

${ }^{7}$ Ibidem, p. 45.
} 
As rápidas menções que Canguilhem havia feito a Febvre e Bloch em seus textos mais conhecidos não eram indícios suficientemente fortes para deter a atenção dos comentadores. Foi preciso aguardar a abertura dos arquivos de Canguilhem. Como escreveu o amigo Raymond Aron em suas Mémoires: Canguilhem "trabalhou, ensinou, escreveu (todos os seus cursos eram redigidos) muito mais do que suas publicações o sugerem" ${ }^{\text {" }}$. Mas, além desse conhecimento parcial do trabalho de Canguilhem, havia também o preconceito segundo o qual Canguilhem não passava de um continuador da obra de Bachelard. Nesses termos, o nascimento da consciência histórica de Canguilhem deveria coincidir com a aparição em suas obras dos traços que caracterizariam a chamada "epistemologia histórica", o que veio a acontecer somente com a tese sobre a formação do conceito de reflexo, de 1955, cujo objetivo, seu autor explica, é "contribuir com a constituição, no que concerne à biologia, daquilo que chamamos, com o Sr. Bachelard, 'uma história recorrente, uma história que nós podemos esclarecer pela finalidade do presente'."9

Certamente o desconhecimento da real extensão da obra de Canguilhem contribuiu para que muitos comentadores negligenciassem durante tanto tempo seu interesse pelos trabalhos de historiadores, que, hoje, começamos a entender ter sido longínquo em sua biografia e determinante em sua obra. Mas somente um preconceito tão solidamente fixado e amplamente difundido quanto aquele a respeito da relação com Bachelard explicaria o desdém dos principais comentadores de Canguilhem pelos seus débitos com a obra de Henry Sigerist, o mais ilustre historiador da medicina do século passado. Ao explorarmos tais débitos, conseguimos mostrar que, antes da aproximação com Bachelard, Canguilhem já refletia sobre os métodos e os objetos da história das ciências e, assim, entendemos porque, antes dos filósofos marxistas franceses na década de 60 , foram os próprios historiadores que, nos anos 40 , notaram a contribuição original da tese de Canguilhem sobre o normal e o patológico para o debate historiográfico.

\section{Sigerist na França}

Segundo o Dictionnaire de la pensée médicale, organizado por Dominique Lecourt, as três correntes da historiografia médica do século XX que marcarão de maneira duradoura o modo de escrever e pensar a disciplina são "as Escolas” germano-americana, polonesa e francesa,

\footnotetext{
${ }^{8}$ Citado por Jacques Bouveresse no prefácio ao primeiro tomo das obras completas de Canguilhem (p. 8). A amizade entre Aron e Canguilhem teve início quando eles eram colegas de classe na École Normale Supérieure de Paris (Sartre estava na mesma turma). Entre os documentos preservados no CAPHÉS, Aron é a segunda entrada mais frequente, atrás apenas de Alain.

${ }^{9}$ CANGUILHEM, La formation du concept de réflexe aux XVIIe et XVIIIe siècles, p. 167.
} 
cujos principais representantes seriam, respectivamente, Henry Sigerist, Ludwik Fleck e Georges Canguilhem. O verbete "Histoire de l'histoire de la médecine", escrito por Christiane Sinding, não chega a explorar as relações possíveis entre essas correntes, ainda que admita que, em diferentes aspectos, Fleck está próximo de posições desenvolvidas por Canguilhem de maneira independente ${ }^{10}$. Essa aproximação entre as correntes francesa e polonesa foi explorada, a partir dos trabalhos de seus principais representantes, primeiramente, por Jean-François Braunstein e, mais recentemente, por Mauro Condé, em textos que exploraremos no quinto e último capítulo. Não temos notícia de uma tentativa de aproximação semelhante entre as escolas francesa e germano-americana.

Diante da busca paciente de Vázquez García por referências de Canguilhem a Bloch e a Febvre em arquivos de milhares de páginas manuscritas, e do trabalho de história intelectual comparada que permitiu a Braunstein identificar o que chamou de "air de famille" entre Canguilhem e Fleck, não deixa de impressionar a escassez de comentários sobre a leitura que Canguilhem fez de Sigerist. Afinal, na principal obra de Canguilhem, as referências a Sigerist saltam aos olhos, a propósito de questões fundamentais, rodeadas pelos mais elogiosos adjetivos e escritas em tom de reconhecimento de uma dívida intelectual. De tal maneira que, se Braunstein fez do desconhecimento mútuo de Fleck e Canguilhem o ponto de partida de sua reflexão, nosso problema é saber determinar, por um lado, aquilo que Canguilhem deve à sua leitura de Sigerist e, por outro, as semelhanças que, no caso de Canguilhem, teriam começado a ser elaboradas ao longo de uma reflexão prévia à leitura de Sigerist.

Embora toda a obra de Sigerist tenha sido redigida em alemão e inglês, o francês era a sua língua materna. Sigerist nasceu e passou toda a sua infância em Paris, que, nas primeiras linhas de sua inacabada autobiografia, ele descreveu como a "mais maravilhosa cidade na Terra". A cultura científica francesa não era estranha a Sigerist, e nem ele o era a certos círculos intelectuais parisienses. No início dos anos 1920, Sigerist era membro da Société d'histoire de la pharmacie e da Societé française d'histoire de la médecine, e sua obra já era uma referência comum nas reflexões sobre a história das ciências e a história da medicina na França no momento em que Canguilhem elaborava sua tese. Apesar da interpretação fixada atualmente sobre Sigerist, dos trabalhos de sociologia e história social da medicina e da saúde pública que fizeram dele a estrela da manhã da moderna historiografia médica, em seus primeiros trabalhos na década de 20 Sigerist defendia que a história da medicina deveria se ater a um "estrito método filológico histórico", como afirmou em um dos seus primeiros textos programáticos, "Aufgaben und Ziele

\footnotetext{
${ }^{10}$ SINDING, "Histoire de l'histoire de la médecine, p. 577
} 
der Medizingeschichte", de $1922^{11}$. No começo daquela década, seu livro mais celebrado na França, como em toda a Europa, era o Studien und Texte zur frümittelalterlichen Rezeptliteratur, que não passava de uma coletânea de antidotários medievais, seguidos de uma breve análise do seu conteúdo, da classificação das receitas, modo de administração e comentários sobre as fontes da compilação. Em 1923, no Bulletin de la Société d'Histoire de la Pharmacie, Ernst Wickersheimer celebrou o emprego rigoroso da análise filológica, considerando o livro de Sigerist "uma obra notável"12.

A situação mudaria em poucos anos. Na biblioteca de Canguilhem, encontramos, guardado dentro de um livro de Sigerist, o artigo "Civilisation et maladie: d'après un article récent”, escrito pelo próprio Wickersheimer, em 1929, dessa vez publicado no Bulletin de la Societé Française d'Histoire de la Médecine e para atacar publicamente o trabalho de Sigerist. O texto de Wickersheimer, como anuncia seu subtítulo, foi escrito a propósito de outro artigo, intitulado "Kultur und Krankheit", publicado por Sigerist alguns meses antes na revista Kyklos. "Ponto de partida: a doença é largamente influenciada pelas condições gerais da existência. Ideia muito justa, embora não muito nova" ${ }^{\prime 3}$, diz Wickersheimer sobre o trabalho de Sigerist. A originalidade no estabelecimento das relações entre "a patologia de uma época" e "o gênero de vida que então levavam as diversas classes da sociedade", segundo Wickersheimer, pertence a Émile Littré, que havia dedicado grande interesse e várias páginas à história das epidemias. Como prova dessa originalidade, Wickersheimer destaca o artigo "Des grandes épidémies", publicado por Littré na Revue des deux mondes em 1836. Assim, atribuía a Sigerist apenas um "curioso" esforço de "perseguir a ideia de Littré até as suas últimas consequências", a saber, "uma sincronia necessária entre os fatos da história das doenças e os fatos da história geral".

A sugestão de continuidade entre as ideias de Sigerist e as de Littré parecia plausível no momento em Wickersheimer escrevia. Em 1930, ano seguinte à publicação do artigo de Wickersheimer, o Instituto de História da Medicina da Universidade de Leipzig, do qual Sigerist era o diretor, adquiriu através de leilão um manuscrito de Littré sobre Charles Daremberg. O manuscrito, datado de fevereiro de 1862, foi publicado no Sudhoffs Archiv für Geschichte der Medizin com uma breve apresentação de Sigerist, na qual podemos ler já nas primeiras linhas a seguinte avaliação: “A moderna história da medicina teve seu ponto de partida na França. Littré e Daremberg são seus porta-vozes" $"$. Sigerist acreditava que o manuscrito de Littré era uma

\footnotetext{
${ }^{11} C f$. TEMKIN, "Henry E. Sigerist and aspects of medical historiography", p. 124.

${ }^{12}$ WICKERSHEIMER, "Henry E. Sigerist, Studieuse und Texte zur frühmittelalterlichen Rezeptliteralur", p. 201.

${ }^{13}$ WICKERSHEIMER, "Civilisation et maladie. D'après un article récent”, p. 31.

${ }^{14}$ SIGERIST, "Littré über Daremberg”, p. 382. Sobre as contribuições de Daremberg à história da medicina, Cf. BRAUNSTEIN, Jean-François. "Daremberg et les débuts de l'histoire de la médecine en France". In. Revue
} 
espécie de carta de recomendação para a primeira cadeira de história da medicina na França, criada em 1870, antes mesmo da criação da primeira cadeira de história geral das ciências. Com o apoio de Littré, Daremberg foi de fato eleito para a Faculté de Médecine e, nas décadas seguintes, encorajou os historiadores a perseguirem uma história filológica e erudita, atenta à interpretação interna dos textos médicos - uma orientação que Sigerist seguira fielmente no começo da sua carreira.

Para Wickersheimer, Littré havia comprovado com sucesso que a origem das doenças epidêmicas poderia ser investigada a partir "das mudanças enfrentadas pelas formas de vida dos homens" 15 , enquanto Sigerist cometia um grave erro ao fazer coincidir, sem explicar as razões, o surgimento de certas doenças e alguns episódios decisivos da história geral: a peste bubônica (dita "peste de Justiniano") e a peste negra com o começo e o fim da Idade Média, respectivamente; a sífilis com a origem do Renascimento; a doença inglesa do suor (sudor anglicus) com o fim da Guerra das Duas Rosas... Procedendo assim, ironizou Wickersheimer, apenas em torno da história da Inglaterra Sigerist já teria uma enormidade de temas a sugerir a seus alunos em Leipzig: bastava descobrir fatos patológicos que coincidissem com a Carta Magna (1215), com a ruptura de Henrique VIII com Roma (1533) ou com a execução de Jaime I (1649). "Falando francamente, eu prefiro o bom e velho Plínio", concluiu Wickersheimer, afinal, "se ele acreditou que um cometa pressagiou a Guerra Civil, pelo menos ele não pretendeu que o cometa causou a Guerra; e tampouco disse que foi a Guerra que engendrou o cometa"16.

Mas o texto de Sigerist, - cujo título Wickersheimer repete, "Civilisation et maladie" -, não é apenas um "artigo recente" publicado em uma revista qualquer. Kyklos era o anuário do Instituto de História da Medicina da Universidade de Leipzig, fundado por Karl Sudhoff em 1906, e dirigido por Sigerist desde 1925. O Instituto era subdividido em quatro departamentos: Medicina Geral, Farmacologia, História Cultural e Patologia. "Kultur und Krankheit", na verdade, sequer era um artigo, o resultado de uma investigação minuciosa sobre um problema específico, mas a descrição do programa de trabalho estabelecido por Sigerist para o Departamento de Patologia, que se dedicava ao estudo das relações de estilo entre as doenças e a cultura $^{17}$. Por conta da Guerra, esse trabalho realizado em Leipzig só foi apresentado de modo sistemático numa série de conferências pronunciada na Cornell University em $1940^{18}$ e publicada

\footnotetext{
de l'histoire des sciences. 2005, Tome 58, $\mathrm{n}^{\circ}$ 2, pp. 367-387.

${ }^{15}$ WICKERSHEIMER, “Civilisation et maladie. D'après un article récent”, 32.

${ }^{16}$ WICKERSHEIMER, "Civilisation et maladie. D'après un article récent”, 32.

${ }^{17} \mathrm{Cf}$. FEE, Elizabeth e BROWN, Theodore M (ed.). Making medical history: the life and times of Henry E. Sigerist. The Johns Hopkins University Press: Baltimore/Londres, 1997. Mais precisamente, o artigo de Ingrid Kästner, “The Leipzig Period, 1925-1932”, pp. 42-62.

${ }^{18}$ KÄSTNER, “The Leipzig Period, 1925-1932”, p. 50.
} 
sob o título Civilization and disease ${ }^{19}$, único livro de Sigerist traduzido no Brasil, com um esclarecedor texto introdutório de Everardo Duarte Nunes. Em 1929, Wickersheimer não compreendeu que "Kultur und Krankheit" era um sinal do afastamento de Sigerist da sombra paterna de Karl Sudhoff, a quem também pagava tributos pela sua abordagem filológica da história da medicina, e, ao mesmo tempo, um sinal da aproximação das ideias de Oswald Spengler e sua morfologia cultural ${ }^{20}$.

Em "Kultur und Krankheit", Sigerist apenas ensaiava os primeiros movimentos de uma renovação na historiografia científica, abrindo a medicina para além da história das ciências. Ao relacionar doença e civilização, Sigerist pretendia, por um lado, demonstrar que certas doenças, especialmente as epidemias, influíam sobre as transformações políticas e econômicas das nações e, ao mesmo tempo, tinham consequências sobre a vida cultural dos povos, ao mesmo tempo em que dela derivada: não é o Renascimento que faz nascer a sífilis, mas o estilo do homem renascentista que ajuda a disseminá-la. Oitenta e cinco anos depois, nossa avaliação é forçosamente diferente da que fez Wickersheimer: dado o estado atual da historiografia médica, sabemos que Sigerist não estava simplesmente revelando sincronias entre fatos patológicos e fatos históricos, mas abrindo uma nova perspectiva, tentando inaugurar novas possibilidades e mesmo objetos de investigação para a história da medicina. Foi a partir dessa nova perspectiva historiográfica que, justamente numa de suas visitas a Paris, na primavera de $1930^{21}$, Sigerist escreveu Einführung in die Medizin, o livro mais importante do seu período europeu, e responsável por apresentar a um público mais amplo a perspectiva histórica que desenvolvia em Leipzig desde que assumiu a direção do Instituto de História da Medicina.

Quando Einführung in die Medizin foi publicado na Alemanha, em 1931, Sigerist já gozava de grande prestígio entre os historiadores das ciências. Além de uma década de experiência profissional na história da medicina, da Universidade de Zurique à Universidade de Leipzig, Sigerist era um militante da história das ciências, tendo fundado em 1928, ao lado de

\footnotetext{
${ }^{19}$ SIGERIST, Civilization and disease. Ithaca, 1945: Cornell University Press.

${ }^{20}$ FEE e BROWN, "Intellectual legacy and political quest: the shaping of a historical ambition", p. 186.

${ }^{21}$ Sigerist anotou nos rascunhos para sua autobiografia: "Quando eu era professor em Leipzig, eu lia jornais e livros franceses todos os dias, e sempre buscava passar a primavera em Paris. Duas dessas primaveras foram particularmente inesquecíveis para mim, as de 1930 e 1931. O semestre de inverno se encerrou no final de fevereiro e eu pude passar os meses de março e abril em Paris. (...) Num ano, eu estava escrevendo enormes seções de uma Introdução à medicina, que mais tarde foi traduzida para seis línguas, incluindo o chinês. No ano seguinte, eu estava trabalhando numa história biográfica da medicina, The Great Doctors, que teve três edições alemãs, duas em inglês e uma em espanhol. Eu tinha os livros que eu mais precisava comigo e boas livrarias eram facilmente acessíveis. Eu escrevia dez páginas por dia, dez fólios manuscritos num caderno azul que eu havia feito especialmente para a ocasião. E quando eu chegava ao final da página dez, eu parava, algumas vezes no meio de uma frase, fazia algumas anotações para a continuidade no dia seguinte, e então eu era um homem livre. (...) Quando a página dez era escrita, eu estava livre e Paris inteira era minha.”
} 
Abel Rey, George Sarton, Charles Singer, Aldo Mieli, Karl Sudhoff e Lynn Thorndike, o Comitê Internacional de História das Ciências, que, no ano seguinte, após um primeiro congresso em Paris, se tornaria a Academia Internacional de História das Ciências - cuja primeira sede foi a biblioteca do Centre de Synthèse, fundado por Henri Berr e ponto de encontro de importantes historiadores das ciências, como Alexandre Koyré, Hélène Metzger e Pierre Brunet. Tudo isso, aliado a uma produção de prosa fácil, mas sem abrir mão da erudição, já havia garantido para Sigerist um grande público leitor.

Os textos de Sigerist repercutiam na França e, de acordo com a revista Archeion, órgão oficial do Comitê e depois da Academia, "basta anunciar os livros de Sigerist para fazer nascer em nossos leitores o desejo de lê-los e possui-los",22. De fato, Einführung in die Medizin foi um grande sucesso editorial à época do seu lançamento, imediatamente traduzido para diversas línguas. A tradução francesa, Introduction à la médecine, foi publicada já em 1932, poucos meses após a publicação do original alemão. Na França, foi sobretudo a originalidade da perspectiva histórica de um manual de introdução aos estudos médicos que explicou a recepção entusiasmada de Introduction à la médecine. Em 1933, Pierre Ménétrier, antigo presidente da Société française d'Histoire de la Médecine, apresentou assim o livro de Sigerist à Académie nationale de médecine: "o professor Sigerist (...) pensou que a melhor maneira de iniciar o jovem estudante, o futuro médico, nas ciências que ele deve aprender, bem como aos deveres e às obrigações de sua profissão, era lhe mostrando seu desenvolvimento histórico, sua lenta evolução e seu progresso". Para Ménétrier, no livro de Sigerist “a história da Medicina não é mais apenas uma pura curiosidade retrospectiva, mas se torna um elemento de ensino científico e profissional da mais evidente atualidade"23. Vejamos as primeiras linhas do livro de Sigerist:

Esse livro se dirige antes de tudo aos jovens homens que escolheram a carreira médica e que se encontram no início dos seus estudos. Ele tenta pintar em traços largos um quadro da medicina, as tarefas que ela se propõe, os problemas que ela evoca. Ele visa dar noções fundamentais, se servindo amplamente para isso do método histórico. Existe melhor procedimento para compreender uma ideia que fazer o leitor participar da sua elaboração? ${ }^{24}$

Síntese das pesquisas realizadas durante meia década à frente do Instituto de História da Medicina em Leipzig, Introduction à la médecine, não era um livro de história, mas uma obra de iniciação destinada aos estudantes nos primeiros anos do curso médico - situação em que o

\footnotetext{
${ }^{22}$ Archeion. Archivio storico della scienza. Organe officiel du Comité international d'histoire des sciences. Rome, volume XIV, t. 3, 1932.

${ }^{23}$ Bulletin de l'Académie nationale de médecine, Jan. 1933, p. 34.

${ }^{24}$ SIGERIST, Introduction à la medicine, Preface.
} 
próprio Canguilhem se encontrava na segunda metade da década de 30, ao mesmo tempo em que dava aulas de filosofia em Toulouse. Na tese de doutorado, Sigerist é frequentemente evocado por Canguilhem, a propósito de diversos temas: a "animação" da anatomia, o isolamento social experimentado pelos doentes, a relatividade individual do normal biológico, a relação entre clínica e endocrinologia etc. Mas é sobretudo "o modo habitual de proceder" de Sigerist, a inclusão das descobertas e ideias científicas "na história intelectual da civilização" 25 ou, para dizer de maneira mais clara, a relação intrínseca que Sigerist estabelece entre a história da medicina e a história das ideias, que chama a atenção de Canguilhem.

Assim como muitas ideias publicadas no Introduction à la Médecine, esse problema tinha sua origem nas pesquisas desenvolvidas no Instituto em Leipzig. Foi em 1928 que Sigerist apresentou a conferência mais tarde publicada sob o título "William's Harvey position in the history of european thought", sobre a descoberta por da circulação do sangue por Harvey em 1628, defendendo a tese de que "a história da circulação do sangue, como a história da ciência em geral, e da medicina em particular, demonstra a íntima aliança com a história da cultura"26. Sigerist parte das seguintes perguntas: "De onde vem que a ideia da função entra na medicina precisamente no começo do século XVII? Por que não mais cedo? Por que não mais tarde? Quais circunstâncias lhe deram nascimento?". Para respondê-las, ele diz, é preciso "situar Harvey com mais precisão na história intelectual europeia"27.

Segundo Sigerist, o objeto da fisiologia é o movimento, uma ideia que não poderia ter sido concebida em outro momento da história intelectual europeia posto que "a fisiologia e a ideia funcionalista na medicina são produtos do barroco" e "Harvey é o primeiro a incorporar o conceito do barroco". Apoiado nas ideias do historiador da arte Heinrich Wölfflin, Sigerist defenderá que o barroco era uma forma de pensamento que reinava sobre todos os domínios do espírito da época. Para Sigerist, Harvey não era diferente de Galileu, em quem teria se produzido, de maneira análoga à da arte de Michelangelo, "uma evolução que o conduziu da ideia estática à ideia dinâmica" ${ }^{28}$. No Ensaio, Canguilhem mostrou ter se impressionado com essas ideias:

Sigerist, que busca definir a fisiologia compreendendo o sentido da primeira descoberta que a inaugurou, a descoberta por Harvey da circulação do sangue (1628), procede de sua maneira habitual, que é situar essa descoberta na história intelectual da civilização. Por que uma concepção funcional da vida apareceu então, nem mais cedo, nem mais tarde? Sigerist não separa a ciência da vida, nascida em 1628, da concepção geral, digamos filosófica, da vida que se

\footnotetext{
${ }^{25}$ CANGUILHEM, Le normal et le pathologique, p. 136.

${ }^{26}$ SIGERIST, "William's Harvey position in the history of european thought", p. 185.

${ }^{27}$ SIGERIST, Introduction à la Médecine, p. 40.

${ }^{28}$ Ibidem, p. 40-42, passsim.
} 
expressa então nas diversas atitudes do indivíduo diante do mundo. As artes plásticas em primeiro lugar, do fim do século XVI e começo do XVII, fixaram o estilo barroco, liberaram o movimento por toda parte. Ao contrário do artista clássico, o artista barroco não vê na natureza senão aquilo que é inacabado, virtual, ainda não circunscrito. "O homem do barroco [escreveu Sigerist] não se interessa por aquilo que é, mas por aquilo que vai ser. O barroco é infinitamente mais que um estilo na arte, é a expressão de uma forma de pensamento que reina nessa época em todos os domínios do espírito: a literatura, a música, a moda, o Estado, o modo de viver, as ciências". Os homens do começo do século XVI, fundando a anatomia, privilegiaram o aspecto estático, delimitado, da forma viva. Aquilo que Wölfflin diz do artista barroco, que ele não vê o olho, mas o olhar, Sigerist diz do médico no começo do século XVII: "Ele não vê o músculo, mas sua contração e o efeito que ela produz. Eis como nasce a anatomia animata, a fisiologia. O objeto dessa ciência é o movimento. Ela abre as portas ao ilimitado. Cada problema fisiológico conduz às fontes da vida e permite as fugas sobre o infinito". Harvey, ainda que anatomista, não via no corpo a forma, mas o movimento. Suas pesquisas não são fundadas sobre a configuração do coração, mas sobre a observação do pulso e da respiração, dois movimentos que só cessam com a vida. ${ }^{29}$

Pierre Macherey, em 1964, na primeira análise de conjunto da obra de Canguilhem que se tem notícia, afirmou que o objetivo da tese de medicina é "mostrar em que terreno ao certo se constituiu a fisiologia, 'o espírito da fisiologia nascente' (ver a chamada a Sigerist, a propósito da obra de Harvey): uma ciência das condições de saúde". Curiosamente, quando decidiu reeditar seu texto em 2009, para a coletânea De Canguilhem à Foucault, la force des normes, Macherey excluiu a referência a Sigerist. Mais recentemente, Claude Debru, no artigo "Georges Canguilhem et la rationalité du pathologique”, lembra, en passant, porém mais decidido, que a ideia de Sigerist do movimento como objeto da fisiologia, a partir de uma concepção barroca, foi determinante para a argumentação de Canguilhem, para quem esse "espírito" da físiologia nascente teria sido incorporado na definição da fisiologia como "ciência das condições de saúde" ${ }^{30}$.

Canguilhem jamais abandonou a ideia contida nessa frase: "Sigerist não separa a ciência da vida, nascida em 1628, da concepção geral, digamos filosófica, da vida que se expressa então nas diversas atitudes do indivíduo diante do mundo". A referência a Sigerist nos ajuda a restabelecer o papel central do Ensaio sobre alguns problemas relativos ao normal e ao patológico no processo que chamamos historicização das ciências. O desenvolvimento dessa proposição na obra de Canguilhem abriu o caminho para a elaboração da noção do objeto da história das ciências como um objeto cultural, e, imediatamente na obra de Canguilhem, fez

\footnotetext{
${ }^{29}$ CANGUILHEM, Le normal et le pathologique, 136.

${ }^{30}$ DEBRU, Georges Canguilhem, science et non-science, p. 42.
} 
deslocar o interesse histórico das respostas para as questões. Ou seja, em vez de buscar escrever a história das conquistas da medicina e das ciências da vida, Canguilhem passou a se perguntar pelas condições de possibilidade histórica de um determinado problema e as condições que permitiram que uma teoria fosse aceita como verdadeira. Dissemos, no primeiro capítulo, que, segundo Foucault, Canguilhem, ao escolher as ciências da vida e da medicina, não apenas aumentou o campo de abrangência da história das ciências, mas também remanejou a disciplina em torno de alguns pontos essenciais. Apresentamos a "descontinuidade" e a "recorrência", para falar de um modo mais geral sobre o método histórico de Canguilhem, mas, a partir desse enunciado que Canguilhem encontrou na obra de Sigerist, podemos rastrear, no Ensaio de 1943, aquilo que conferiria "uma secreta unidade e uma sólida coerência a toda obra históricoepistemológica"31 de Georges Canguilhem.

\section{A história das ideias em 1943}

Foi em sua tese de doutorado em medicina que Canguilhem manifestou pela primeira vez o desejo de não ser confundido: “(...) não pretendemos passar por historiador da medicina. Se na primeira parte colocamos o problema em perspectiva histórica, foi unicamente por razões de mais fácil inteligibilidade, ${ }^{, 32}$. A preocupação acompanhava uma avaliação severa da historiografia de sua época, que Canguilhem percebia demasiadamente dedicada aos estudos dos grandes médicos e seus feitos: "Não temos nenhuma pretensão de erudição no campo da biografia" 33 , ironizou ("ecoando Bloch e Febvre", talvez acrescentasse Vázquez García). Evitava, assim, que os capítulos de sua tese dedicados a Broussais, Comte e Claude Bernard fossem confundidos com os panegíricos habituais dos historiadores da medicina de então. Sem minimizar o fato de que o Ensaio é um texto de filosofia da medicina, entendemos que, apoiado em Sigerist, Canguilhem começava a elaborar, já em 1943, uma nova maneira de refletir historicamente sobre as ciências da vida. Ainda que o tenha feito "unicamente por razões de mais fácil inteligibilidade", a novidade não passou despercebida pelos historiadores de ofício, como atesta aquela resenha de Brunet para revista do Centre de Synthèse.

Canguilhem inicia o Ensaio com um exame histórico da tese amplamente difundida no século XIX segundo a qual os fenômenos patológicos seriam apenas variações quantitativas, e não qualitativas, dos fenômenos normais do organismo. Antes, porém, de passar à crítica dessa

\footnotetext{
${ }^{31}$ DELAPORTE, "La problématique historique et la vie", p. 226.

${ }^{32}$ CANGUILHEM, Le normal et le pathologique, p. 8.

${ }^{33} \mathrm{Idem}$.
} 
teoria, Canguilhem apresentou as chamadas concepções ontológica e dinâmica da doença, que enxergam a doença ora como a luta contra um ser estranho que invade o homem, ora como a luta interna de forças que se afrontam no homem. "As doenças de carência e todas as doenças infecciosas ou parasitárias fazem a teoria ontológica marcar um ponto", escreveu Canguilhem. Por outro lado, "as perturbações endócrinas e todas as doenças marcadas pelo prefixo dis reafirmam a teoria dinamista ou funcional". A concepção ontológica da doença pretende ser capaz de localizar o mal e combatê-lo. É a ideia de doença que atinge o homem, trazida de fora, e que, portanto, pode ser expulsa dele. Pasteur, afirma Canguilhem, deve muito do seu sucesso ao fato de suas teorias conterem uma representação ontológica do mal, o micróbio, entidade externa, visível, localizável (ao contrário dos miasmas) e, mais importante, combatível. Já na concepção dinâmica, a doença não pode ser localizada; ela está na totalidade do homem que perdeu sua harmonia interna, ainda que por alguma alteração no seu meio. Porém, nessa concepção, a doença é tanto a desarmonia quanto o esforço da natureza para obter um novo equilíbrio, o que exige uma medicina expectante, que tolere ou reforce essa terapêutica espontânea. Duas concepções de doença, dois tipos de otimismo: na técnica humana e na ação da natureza ${ }^{34}$.

Vale dizer que essa diferenciação entre a concepção ontológica e a concepção dinâmica das doenças não é uma ideia original de Canguilhem. Foi novamente no livro Introduction à la médecine, de Sigerist, que Canguilhem afirmou ter encontrado "uma explanação sumária e magistral de toda essa evolução das ideias médicas”, que vai da medicina egípcia - a partir da qual houve uma "generalização da experiência oriental das afecções parasitárias, combinando-a com a ideia de doença-possessão" - e da medicina grega - segundo a qual "a natureza (physis), tanto no homem como fora dele, é harmonia e equilíbrio" - até a formação, no século XIX, de uma teoria que via doença e saúde como variações quantitativas dos mesmos fenômenos fisiológicos. Não é para depreciar a teoria que Canguilhem usa a palavra "dogma" quando fala da identidade qualitativa entre o normal e o patológico no século XIX, mas sim para “fazer com que sua repercussão e seu alcance sejam bem apreendidos” (a palavra "dogma” já havia sido empregada no caso, citado há pouco, das teorias microbianas das doenças contagiosas de Pasteur).

\footnotetext{
${ }^{34}$ Não raro esse "otimismo apaziguador" fez com que o pensamento médico oscilasse entre uma concepção e outra. No Brasil, Sérgio Arouca, em O dilema preventivista, constata, apoiado em Canguilhem, que a concepção dita "ecológica" de doença que caracteriza a medicina preventiva é, na verdade, a reunião das concepções ontológica e dinâmica: agentes externos são os causadores das doenças contagiosas, mas favorecidos por um desequilíbrio, seja do hospedeiro ou do meio. Assim, o conceito ecológico de doença seria duplamente otimista, "já que é sempre possível eliminar e (ou) equilibrar". In: AROUCA, $O$ dilema preventivista, pp. 157-160, passim.
} 
Canguilhem destaca que Comte foi buscar no sistema médico de Broussais a tese segundo a qual as doenças seriam apenas sintomas do "excesso ou falta de excitação dos diversos

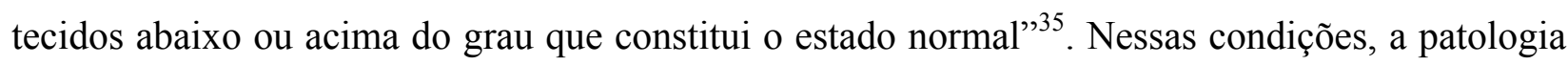
se apresentaria como um prolongamento da fisiologia, isto é, os fenômenos normais seriam idênticos aos fenômenos patológicos, exceto por um certo número de variações quantitativas. Segundo Canguilhem, a identidade entre os fenômenos normais e patológicos aparece ao longo de toda a "evolução intelectual" de Comte, ou seja, do período preparatório do Curso de filosofia positiva (1830-1842) ao Sistema de politica positiva (1851-1854), suas duas obras mais importantes ${ }^{36}$. Comte aderiu publicamente àquele princípio em 1828 , numa resenha do livro De l'irritation et de la folie, de Broussais. Segundo Canguilhem, desde então, a tese de que as doenças são sintomas da mudança de intensidade na ação dos estimulantes indispensáveis à saúde teria assumido um papel de axioma geral na filosofia de Comte, que lhe concedeu o mesmo "valor dogmático" atribuído à lei de Newton, mas à sua maneira. Canguilhem mostrará que o "princípio de Broussais" também foi investido de autoridade por Comte na ordem política. Mais que isso, ele argumenta, foi o valor político do princípio de Broussais que levou Comte a reconhecer, retroativamente, seu valor dogmático para a biologia. Foi essa operação, o uso particular da tese - tornada "princípio" - de Broussais na filosofia positiva que permitiu que Comte praticamente reivindicasse para si a paternidade da ideia. No Sistema de política positiva Comte afirma que:

Esse tratado [o Traité philosophique d'astronomie populaire, 1844] baseia-se no grande princípio cuja descoberta tive de atribuir a Broussais, porque sobressai do

\footnotetext{
${ }^{35}$ COMTE, "Examen du Traité de Broussais sur l'irritation, 1828", apêndice ao Système de politique positive, t. IV, p. 216, Apud CANGUILHEM, Le normal et le pathologique, p. 18-19.

${ }^{36}$ Jean-François Braunstein, em seu livro La philosophie de la médecine d'Auguste Comte, esclarece que as ideias de Comte sobre a relação entre biologia e medicina conheceram uma inversão completa ao longo de sua obra. Se, no Curso de filosofia positiva, escrito entre 1830 e 1842, a medicina era simples aplicação da biologia, entre 1854 e 1857, na correspondência mantida com seu discípulo Georges Audiffrent, Comte se manifestou contra a subordinação da patologia à biologia e a favor do estudo clínico. Essa correspondência que, segundo Braunstein, apresenta de modo mais completo a "filosofia da medicina" de Comte foi publicada em 1860 e em 1862 sob o título "Lettres sur la maladie". Ainda segundo Braunstein, essa mudança teria acontecido tanto em função da evolução do pensamento de Comte, crítico do que interpretou como uma degeneração, a partir das universidades, da biologia em um simples materialismo (dupla redução: do moral ao físico, e da biologia à física e à química), quanto pela própria difusão do positivismo para além do círculo próximo ao seu sacerdote. "A maioria dos [positivistas] 'dissidentes' são recrutados entre os biólogos, enquanto que os [positivistas] ortodoxos são, em sua maioria, simples médicos", explica Braunstein. Não obstante, Braunstein concede que, de fato, foi o Comte do "princípio de Broussais", ou seja, aquele da medicina subordinada à biologia, estudado por Canguilhem no Ensaio, que se impôs no século XIX. Assim, se Canguilhem não percebeu essa mudança na obra de Comte, parece-nos que permaneceu fiel ao seu projeto de história das ideias.
} 
conjunto de seus trabalhos, embora somente eu tivesse elaborado sua formulação geral e direta. (...) Além de sua eficácia direta para as questões biológicas, ele [o princípio] constituirá, para o sistema geral da educação positiva, uma vantajosa preparação lógica aos processos análogos para a ciência final. Pois o organismo coletivo, em virtude de sua complexidade superior, comporta perturbações ainda mais graves, mais variadas e mais frequentes que a do organismo individual. Não tenho medo de assegurar que o princípio de Broussais deve ser estendido até esse ponto, e já o apliquei nesse campo para confirmar ou aperfeiçoar as leis sociológicas. Contudo, a análise das revoluções não poderia esclarecer o estudo positivo das sociedades, sem que haja, a esse respeito, a iniciação lógica resultante dos casos mais simples apresentados pela biologia. ${ }^{37}$

Essa eficácia direta para as questões biológicas diz respeito ao fato de que a doença, para Comte, é um substituto superior da experimentação para o conhecimento sobre o homem normal, pois a exploração experimental estaria sempre limitada à manutenção das condições de existência do fenômeno e seria muitas vezes impraticável no homem. A doença serviria, assim, como uma experimentação espontânea, e o que haveria em Comte seria um interesse conceitual pelo patológico para conhecimento do homem normal. Com isso, Canguilhem argumenta, Comte pretendia fundamentar cientificamente uma doutrina política: "Afirmando de modo geral que as doenças não alteram os fenômenos vitais, Comte justificava a afirmação de que a terapêutica das crises políticas consiste em retornar as sociedades às suas estruturas essenciais e permanentes" e, ao mesmo tempo, "não tolerar o progresso senão nos limites de variação da ordem natural que define a estática social" 38 .

Ora, dado que, em Comte, o “princípio de Broussais” está subordinado ao um sistema político, por que recuar até aí uma investigação filosófica sobre tal princípio nosológico? Porque, diz Canguilhem, "mesmo no meio médico da cultura, as teorias de patologia geral próprias a Bichat, a Brown e a Broussais só exerceram influência na medida em que Comte reconheceu seu valor" 39 . Foram os médicos, biólogos e literatos "de inspiração e de tradição positivista" que elevaram e difundiram o "princípio de Broussais" da sociologia comteana como uma concepção independente. Assim, Canguilhem explica, "remontar às fontes distantes das ideias de Comte, através da patologia de Broussais, de Brown e de Bichat, nos permite melhor compreender o alcance e o limite dessas ideias". Pode-se objetar que, difundida na civilização, transposta de sua origem intelectual para outros domínios da cultura, uma tese científica dificilmente manteria sua integridade, e que, em relação àquela concepção nosológica de origem propriamente médica, derivada, em Broussais, dos estudos de Bichat, o "dogma" comteano seria uma "deformação".

\footnotetext{
${ }^{37}$ COMTE, Examen du Traité de Broussais sur l'irritation, p. 19.

${ }^{38}$ CANGUILHEM, Le normal et le pathologique, p. 31.

${ }^{39}$ Ibidem, p. 30.
} 
Mas, longe de ser uma limitação, Canguilhem encontra aí um terreno favorável para o exercício da sua história das ciências escrita em relação com a história das ideias: "diríamos que as deformações que ela [a tese] sofre no meio cultural podem revelar sua significação essencial” ${ }^{40}$.

A escolha por Claude Bernard, Canguilhem explica, também tem por objetivo facilitar a compreensão sobre o alcance dessas ideias no pensamento médico do século XIX. Canguilhem menciona, a título de exemplo, as relações entre o naturalismo literário do século XIX e as doutrinas médicas e biológicas de Claude Bernard, e também lembra que Nietzsche, em La volonté de puissance, apoiou-se nas Leçons sur la chaleur animale para afirmar que "o valor de todos os estados mórbidos consiste no fato de demonstrarem sob uma lente de aumento certas condições que, apesar de normais, são dificilmente visíveis no estado normal”41 Canguilhem alerta que, embora Claude Bernard não cite diretamente Comte para tratar do problema da relação entre os estados normal e patológico, pode-se notar a presença daquelas ideias impulsionadas pelos discípulos de Comte. Além disso, segundo Canguilhem, as anotações de Claude Bernard, às quais teve acesso, demonstram que ele lia Comte "de perto e com a pena na mão". Da mesma forma que muitos médicos do século XIX ignoravam Broussais e Bichat, mas estavam familiarizados com as obras de Comte e de Littré, para Canguilhem, "hoje em dia a maior parte dos fisiologistas não podem ignorar Claude Bernard, mas desconhecem Bichat, a quem Claude Bernard se associa pelo intermédio de Magendie". Segundo Canguilhem, "para os médicos e biólogos do Segundo Império, Magendie, Comte e Claude Bernard são três deuses - ou três demônios - de um mesmo culto" ${ }^{42}$.

Porém, à diferença de Comte, que foi buscar seu "princípio" na obra de Broussais, a tese da identidade entre o normal e o patológico "em Claude Bernard é a conclusão tirada de toda uma vida de experimentação biológica, da qual a célebre Introduction à l'étude de la médecine expérimentale codifica metodicamente a prática" ${ }^{\text {"43 }}$. É preciso marcar bem o significado dessa diferença. Se, para Comte, o interesse se dirige do patológico para o normal, a fim de determinar especulativamente as leis do normal, em Claude Bernard, diz Canguilhem, "o interesse se dirige do normal para o patológico, para fins de uma ação raciocinada sobre o patológico”. Ele continua:

[em Claude Bernard] é como fundamento de uma terapêutica decididamente em ruptura com o empirismo que o conhecimento da doença é buscado no meio da fisiologia e a partir dela. A identidade do normal e do patológico é afirmada em

\footnotetext{
${ }^{40}$ Ibidem p. 17.

${ }^{41}$ NIETZSCHE, La volonté de puissance, $§ 533$.

${ }^{42}$ CANGUILHEM, Le normal et le pathologique, p. 32.

${ }^{43}$ Ibidem, p. 14.
} 
benefício da correção do patológico. Enfim, a afirmação da identidade permanece, em Comte, puramente conceitual, enquanto Claude Bernard tenta dar precisão a essa identidade em uma interpretação de tipo quantitativo e numérico. ${ }^{44}$

O rigor historiográfico de Canguilhem já é digno de nota mesmo aqui. Afinal, como ele mesmo adverte, a identidade entre o normal e o patológico não é propriamente um tema de especulação teórica em Claude Bernard, certamente não como é em Comte. É preciso seguir com atenção os trabalhos de Claude Bernard, detectar seus pressupostos, ressaltar suas conclusões implícitas. Canguilhem o demonstra a partir das teses de Claude Bernard acerca da presença de açúcar na urina diabética, mostrando como ele se volta contra uma interpretação que vê a glicosúria como um fenômeno novo no indivíduo doente, caracterizando, portanto, um estado qualitativamente diferente. Para Claude Bernard, é preciso, no entanto, se voltar não para os resultados da função renal, mas para o seu mecanismo de funcionamento. Ou seja, se a glicosúria é vista como principal sintoma da diabetes, há uma diferença qualitativa entre a urina normal e a urina com açúcar (essa era a interpretação fixada até a polêmica inaugurada por Claude Bernard). Mas se o pensamento médico compreende a urina como produto da função renal, e considera a relação entre o filtro renal e a composição do sangue, então a glicosúria é o transbordamento, isto é, a variação quantitativa, do limiar de glicemia. "Toda doença tem uma função normal correspondente da qual ela não passa de uma expressão perturbada, exagerada, diminuída ou anulada"45, escreveu Claude Bernard em suas Leçons sur le diabète et la glycongenèse animale, de 1877. Isso é dito mais claramente, ainda nas palavras de Claude Bernard, nas Leçons sur la chaleur animale, publicadas um ano antes, onde é enunciada a teoria da qual o livro sobre a diabetes pretende ser a demonstração clínica:

A saúde e a doença não são dois modos que diferem essencialmente, como
talvez tenham pensado os antigos médicos e como ainda pensam alguns. É
preciso não fazer da saúde e da doença princípios distintos, entidades que
disputam uma à outra o organismo vivo e que dele fazem o teatro de suas lutas.
Isso são velharias médicas. Na realidade, entre essas duas maneiras de ser há
apenas diferenças de grau: a exageração, a desproporção, a desarmonia dos
fenômenos normais constituem o estado doentio. Não há um único caso em que
a doença tenha feito surgir condições novas, uma mudança completa de cena,
produtos novos e especiais. ${ }^{46}$

Por mais específicas que as lições sobre a glicogênese possam parecer elas sustentam bem esse princípio geral de patologia e, o mais importante, por meio de argumentos controláveis,

\footnotetext{
${ }^{44}$ CANGUILHEM, Le normal et le pathologique, p. 15.

${ }^{45}$ Ibidem, p. 34.

${ }^{46}$ Ibidem, p. 36.
} 
protocolos de experiências métodos de quantificação dos conceitos físiológicos (glicogênese, glicosúria, glicemia etc.). "Desde então", avalia Canguilhem, "quando se acha que a doença é a expressão exagerada ou a expressão diminuída de uma função normal, sabe-se exatamente o que se quer dizer. Ou pelo menos têm-se os meios de sabê-lo" "47. Ao fazê-lo, Claude Bernard transforma a continuidade entre os estados normal e patológico em axioma fundador da fisiologia como regente da terapêutica, afirmando uma superioridade da ciência sobre a técnica, isto é, fazendo com que a clínica fosse a aplicação dos conhecimentos produzidos pela físiologia. Assim, Canguilhem nos apresenta a história daquele que já foi chamado de "o primeiro grande paradigma das ciências da saúde em seus traços modernos" ${ }^{\text {"4 }}$.

Em suma, Claude Bernard formulou, no campo médico, com a autoridade de todo inovador que prova o movimento andando, a exigência profunda de uma época que acreditava na onipotência de uma técnica baseada na ciência, e que se sentia à vontade na vida, apesar, ou talvez por causa das lamentações românticas. Uma arte de viver - e a medicina o é no pleno sentido da palavra implica uma ciência da vida. Uma terapêutica eficaz supõe uma patologia experimental; uma patologia experimental não se separa de uma fisiologia. "Fisiologia e patologia se confundem e são uma única e mesma coisa."

Para Canguilhem, a continuidade entre o normal e o patológico reforça uma ideia que está na sua origem, a de que a técnica é aplicação da ciência, que a medicina é aplicação dos conhecimentos fisiológicos. O problema é que, ao fazê-lo, ela não apenas rompe com aquela ideia de doença como representação do mal, isto é, não apenas rompe com a teoria ontológica da doença, mas conduz ao esvaziamento do próprio conceito de doença. Tudo isso em nome de uma pretensa objetividade da patologia. Não por acaso esse momento de vitória da racionalidade científica moderna marca também o ocaso do doente, quer dizer, o fato de que, desde então, o clínico tenha adotado cada vez mais a posição do fisiologista em vez da do doente. O fato de que se possa falar de "saúde" e "doença" como fatos fisiológicos desprovidos de valoração subjetiva e o fato de que se possa falar do normal e do patológico como variantes quantitativas de um mesmo estado fisiológico, condições necessárias para a fundação de uma patologia e, consequentemente, de uma terapêutica "verdadeiramente científicas", estão na base da desumanização da doença, da ideia de "doença sem doente": a invalidade do julgamento do doente sobre sua própria doença, sobre aquilo que constitui os estados "normal" e "patológico", princípio tão caro à teoria de Leriche, também estudada por Canguilhem no Ensaio. É a desconsideração pela opinião do doente, pelos valores com os quais ele avalia sua própria vida, que preserva o patologista da

\footnotetext{
${ }^{47}$ CANGUILHEM, Le normal et le pathologique, p. 39.

${ }^{48}$ AYRES, Epidemiologia e emancipação, p. 100.

${ }^{49}$ CANGUILHEM, Op. cit., p. 48-49.
} 
necessidade de conceber a doença em sua totalidade orgânica e subjetiva, isto é, como uma manifestação diferente da vida. Enxergamos, aí, com mais clareza os débitos que o método de Canguilhem tem com a forma de problematização proposta por Sigerist.

"A medicina", disse Sigerist, "é uma das ciências mais estreitamente ligada ao
conjunto da cultura, toda transformação nas concepções médicas sendo
condicionadas por transformações nas ideias de uma época". A teoria que
acabamos de expor, ao mesmo tempo médica, científica e filosófica, comprova
perfeitamente essa proposição [extraída do livro Introduction à la Médecine].
Parece-nos que ela satisfaz simultaneamente a diversas exigências e postulados
intelectuais do momento histórico da cultura no qual ela foi formulada.

Mas, como dissemos, trata-se de entender tanto aquilo que Canguilhem deve a Sigerist quanto aquilo que antecede tal leitura e se estabelece como um elemento original do método canguilhemiano para a história das ciências da vida. No Ensaio, Canguilhem mostra como o conhecimento da vida e de seus corolários - os conceitos de normal e patológico, de saúde e doença - são fundamentais para a compreensão do pensamento e da prática médicas. Retornamos, assim, aos pontos indicados em "A vida: a experiência e a ciência”. Para Foucault, após ter inserido as ciências da vida (fisiologia e patologia) numa perspectiva histórica, Canguilhem teria destacado traços fundamentais que singularizariam a história dessas ciências em relação ao desenvolvimento das outras ciências. Isso porque, para Canguilhem, o problema da vida enquanto objeto científico do biólogo, não pode jamais se desapegar das valorações que o biólogo, em sua condição de ser vivo, impõe sobre seu objeto.

Em seu artigo sobre Canguilhem, Foucault destaca que, no Ensaio, trata-se de mostrar que por mais que o pensamento médico tenha se caracterizado, a partir de um determinado momento da história intelectual europeia, por uma patologia baseada na normalidade, definida estatisticamente e em referência aos domínios físico-químicos, o conhecimento da vida jamais pôde ser reduzido a tais domínios, posto que a vida se constitui como objeto sempre em relação com os fenômenos patológicos, "com a possibilidade da doença, da morte, da monstruosidade, da anomalia e do erro" ${ }^{, 51}$. Mas como superar essa dificuldade representada pela dupla necessidade de se referir aos domínios físico-químicos que conduzem à identificação entre fisiologia e patologia e de fundamentar nos valores biológicos a diferença entre elas sem, no entanto, abandonar o plano científico? Canguilhem, no Ensaio, propõe alguns elementos para uma possível solução. Em primeiro lugar, lembra que, "segundo uso francês", todo objeto científico é passível de medição e explicação causal, o que faz com que toda ciência busque as constâncias e as

\footnotetext{
${ }^{50}$ CANGUILHEM, Le normal et le pathologique, p. 61.

${ }^{51}$ FOUCAULT, "A vida: a experiência e a ciência”, p. 362.
} 
determinações métricas. Em seguida, admite que esse ponto de vista científico representa uma escolha $^{52}$ e, como tal, ela se define também por aquilo que exclui, nesse caso, o valor que a experiência vivida dos homens recebe para eles e por eles. "Antes da ciência, são as técnicas, as artes, as mitologias e as religiões que valorizam espontaneamente a vida humana", explicou. "Depois do aparecimento da ciência, são ainda as mesmas funções, mas cujo conflito inevitável com a ciência deve ser resolvido pela filosofia, que é, assim, expressamente, filosofia dos valores" $"$. Essa ideia segundo a qual o "ponto de vista científico representa uma escolha" é um dos exemplos que comprovam a importância da leitura de Nietzsche para Canguilhem. Embora tenha afirmado, durante o curso "La science et l'erreur", ministrado na Sorbonne em 1956, que "Nietzsche não chegou a dar um estatuto positivo às ciências", Canguilhem não discordou da tese exposta pelo filósofo alemão em Verdade e mentira no sentido extramoral. À pergunta "O que é então a verdade?", Nietzsche responde:

Uma multiplicidade incessante de metáforas, de metonímias, de antropomorfismos, em síntese, uma soma de relações humanas que foram retórica e poeticamente elevadas, transpostas, ornamentadas, e que, após um longo uso, parecem firmes, regulares e constrangedoras a um povo: as verdades são ilusões cuja origem está esquecida, metáforas que foram usadas e que perderam a sua força sensível, moedas nas quais se apagou a impressão e que agora não são mais consideradas como moedas de valor, mas como metal. Em todo o caso, não sabemos ainda de onde veio o instinto de verdade: porque até o presente não ouvimos falar senão da obrigação que a sociedade impõe para existir: ser verídico, quer dizer, empregar as metáforas usuais; então, em termos de moral, temos ouvido falar da obrigação de mentir de acordo com uma convenção estabelecida, de mentir gregariamente num estilo que constrange a todos. $^{54}$

\footnotetext{
${ }^{52}$ É no mínimo interessante essa nota biográfica de Gérard Lebrun, extraída do seu artigo "De la supériorité du vivant humain dans L'Évolution créatrice", p. 208: "J'ai été conduit à ce theme par le souvenir que je garde de mon tout premier contact avec l'œuvre de Georges Canguilhem, au début des annés 1950. Un livre comme La connaissance de la vie était bien fait pour déconcerter un étudiant de ce temps-là, dont l'intérêt était centré, à peu près forcement, sur la pensée dialectique et la phénoménologie. On était soudain mis en présence d'un auter dont la force et l'originalité philosophique provenaient en grande partie de sa familiarité avec la biologie et l'histoire des sciences. Cette lecture eut nottament l'effet d'éveiller assez vite ma défiance à l'égard de la notion de «biologisme », très en vogue à l'époque et de résonance aussi infame que celle de «psychologisme». Grâce à Georges Canguilhem, on se apercevait qu'une pensée philosophique n'était nullement triviale parce qu'elle partait du principe que la connaissance est un produit ou - qui sait ? - un accident de la vie - et aussi qu'elle ne conduisait nullement de ce fait à une " animalisation » de l'homme. Sans l'autorité de Georges Canguilhem, il m'aurait été personnellement difficile d'aborder sans parti pris des auteurs comme Nietzsche, Schopenhauer, Bergson, que la formation universitaire de l'après-guerre tendait à nous faire considerer, aux mieux, avec condescendence."

${ }^{53}$ CANGUILHEM, Le normal et le pathologique, p. 149.

${ }^{54}$ NIETZSCHE, O livro do filósofo, p. 69.
} 
É o que acontece com a vida. Segundo Canguilhem, ainda no Ensaio, "o homem, tendo sido levado a criar para si mesmo métodos e uma necessidade de determinar cientificamente o real, vê forçosamente a ambição de determinação do real estender-se à própria vida" 55 . E é aí que se estabelece essa dupla perspectiva sobre a vida: "A vida torna-se um objeto de ciência; e tornou-se, de fato, historicamente, já que nem sempre o foi. Acontece, portanto, que a ciência da vida tem a vida como sujeito — já que ela é um empreendimento do homem vivo —, e também como objeto". Os leitores de As palavras e as coisas provavelmente se lembram do tratamento dado por Foucault à questão da emergência da "vida" enquanto problema científico. Nesse livro de história das ciências, nascido após conversas com Canguilhem (como dissemos páginas atrás), Foucault mostrou como o "Homem" só pôde surgir como problema epistemológico no início do século XIX, quando foi compreendido como um duplo empíricotranscendental, tornando-se, ao mesmo tempo, sujeito e objeto do conhecimento.

Foucault argumenta que as Recherches physiologiques sur la vie et la mort, de Xavier Bichat, exerceram influência determinante na organização do pensamento ocidental no século XIX, pois, como desdobramento da filosofia kantiana, levaram o campo transcendental para o interior dos saberes que, apenas depois dele, podem ser chamados de "ciências da vida". Bichat representa o aparecimento de uma dessas empiricidades que se perceberá constitutiva do homem, a vida, que, por sua vez, só se pode dar ao conhecimento através do corpo e de tudo aquilo a que lhe é próprio, como a morte e a doença. Com Bichat, a vida aparece como um quasetranscendental, pois se situa ao lado do corpo, assumindo o papel de uma empiricidade encontrada como fundamento de qualquer experiência, como condição de possibilidade de todo conhecimento sobre o homem. Foucault, que analisou outras duas empiricidades, o trabalho e a linguagem, mostrou que muito do que se acreditava como intrínseco à natureza humana foi construído no interior dos saberes e possui uma história própria, que escapa à pretensa história unificada do Sujeito. Assim, o século XIX, ao transformar o Homem em objeto de conhecimento, também engendrava a "morte do Homem", à medida que se percebia o sujeito transcendental como o resultado do cruzamento ortogonal dessas empiricidades.

Para Foucault, a originalidade da abordagem histórica de Canguilhem se deve também ao fato de que, já no Ensaio, ele evidencia como a constituição das ciências da vida - físiologia, patologia, anatomia etc. - avançou por um processo de esclarecimento dos fenômenos físicoquímicos que se operavam no corpo, mas apenas porque tinha reconhecido a vida como fundamento de todo saber possível. É nesse sentido que o vitalismo aparece na história daquelas ciências com uma dupla função: indicador de um problema a ser resolvido (o do fato original da

\footnotetext{
${ }^{55}$ CANGUILHEM, Le normal et le pathologique, p. 149.
} 
vida) e indicador crítico das posições de valor sobre os fenômenos eminentemente físiológicos. Assim, se "o modo de ser da vida e aquilo mesmo que faz com que a vida não exista sem me prescrever suas formas me são dados, fundamentalmente, por meu corpo",56, a valorização do vitalismo por Canguilhem evitaria aquela redução físico-química, cuja função na constituição dos pensamentos médico e biológico teria sido o de "fazer desconhecer que as ciências da vida não podem se abster de uma certa posição de valor que marca a conservação, a regulação, a adaptação, a reprodução etc" ${ }^{\text {"57 }}$. É por isso que, segundo Canguilhem, o fisiologista, mesmo sem o saber, não consegue olhar totalmente a vida de maneira indiferente, como o olhar do físico que estuda a matéria:

É que a atividade científica do fisiologista, por mais que ele a conceba como separada e autônoma em seu laboratório, conserva uma relação mais ou menos estreita, porém incontestável, com a atividade médica. São os insucessos da vida que chamam, que sempre chamaram a atenção para a vida. Todo conhecimento tem sua origem na reflexão sobre um insucesso da vida. Isso não significa que a ciência seja uma receita dos procedimentos de ação, mas, ao contrário, que o progresso da ciência supõe um obstáculo à ação. É a própria vida, pela diferença que estabelece entre seus comportamentos propulsivos e seus comportamentos repulsivos, que introduz na consciência humana as categorias de saúde e de doença. Essas categorias são biologicamente técnicas e subjetivas, e não biologicamente científicas e objetivas. Os seres vivos preferem a saúde à doença. O médico tomou, explicitamente, o partido do ser vivo; ele está a serviço da vida, e é a polaridade dinâmica da vida que ele expressa, quando fala em normal e em patológico. O fisiologista é, muitas vezes, médico, e é sempre um ser vivo; é por isso que a fisiologia inclui em seus preceitos de base que, se as funções de um ser vivo assumem aspectos que podem ser, todos, igualmente explicados pelo cientista, nem por isso esses aspectos são equivalentes para o próprio ser vivo. ${ }^{58}$

Em, suma, nas palavras de Canguilhem em $O$ conhecimento da vida, o vitalismo é, para a história das ciências da vida, "mais uma exigência do que um método, mais uma moral do que uma teoria". 59

\section{A cultura científica}

\footnotetext{
${ }^{56}$ FOUCAULT, As palavras e as coisas, p. 433.

${ }^{57}$ FOUCAULT, “A vida: a experiência e a ciência”, p. 363.

${ }^{58}$ CANGUILHEM, Le normal et le pathologique, p. 149.

${ }^{59}$ CANGUILHEM, La connaissance de la vie, p. 88.
} 
Começamos o capítulo anterior mostrando como, num cenário de transformações na historiografia das ciências, a falsificação da obra de Canguilhem tem como objetivo a interdição da sua leitura para tentar desabilitá-lo enquanto historiador das ciências. Indicamos, na sequência, que, apesar de todos os indícios, não devemos considerar Canguilhem um historiador das ciências "por natureza", mas sem deixar de apontar que a tentativa de redução da preocupação com a história das ciências na obra de Canguilhem a questão tardia de sua "história intelectual pessoal", derivada de seu ofício de professor de história das ciências, está apoiada numa leitura interna dessa obra, que desconsidera todo o contexto intelectual de produção, o próprio campo da história das ciências.

Tendo participado diretamente da organização dos arquivos do CAPHÉS e da publicação dos inéditos, é natural que Limoges se empenhe, como ele mesmo reconhece, em estabelecer uma periodização da obra de Canguilhem. Não nos resta dúvida que essa insistência com a classificação interna dos textos levou Limoges a descartar os esforços historiográficos de Canguilhem no Ensaio, sempre descrita como uma obra de "filosofia biológica" ou de "filosofia médica". Diante daquela resenha de Brunet, Limoges viu apenas o que servia à classificação; entendeu que, já na época do lançamento do Ensaio, os leitores não se "enganavam" sobre a natureza do livro: "Não sendo um estudo histórico...". A partir dessa frase de Brunet, o que seguiu pareceu-lhe de menor importância. Assim, Limoges minimizou o reconhecimento, por Brunet, da perspectiva histórica de Canguilhem sobre as ideias de Broussais e Claude Bernard, afirmando serem semelhantes às análises encontradas nos livros de Émile Meyerson ou Léon Brunschvicg, a quem ninguém ousa acusar de historiadores das ciências.

Talvez tenha sido apenas a obviedade da questão - a aproximação entre história das ciências e história das ideias - para o leitor contemporâneo, após incontáveis transformações no campo da história das ciências, que impediu que Limoges apreciasse adequadamente a resenha de Brunet e a originalidade historiográfica do Ensaio na década de 40. Por não se interessar pela história da historiografia, Limoges não dispunha dos recursos necessários para reconhecer a originalidade do problema da história das ideias destacado por Brunet. O tema da historicização das ciências na obra de Canguilhem, queremos crer, ganha ao ser tratado como um problema de história intelectual e não de história da filosofia.

Em sua argumentação, Limoges lembra que o artigo "La theorie cellulaire", que compõe a segunda parte, intitulada "História", do livro $O$ conhecimento da vida, foi publicado originalmente em 1946 com um subtítulo excluído da reedição de 1952, que, supostamente, revelaria sua verdadeira natureza: "Du sens et du valeur des théories scientifiques". "Em 1946, no sumário da revista, esse artigo havia sido classificado numa seção intitulada 'Filosofia das 
ciências"”, pondera Limoges. "De maneira que o único artigo que daria a uma parte de $O$ conhecimento da vida um caráter francamente histórico aparece de maneira equívoca"60. De nossa parte, preferimos encontrar o lugar dos textos numa história viva, e não numa classificação, daí termos escolhido o problema da historicização das ciências como chave de leitura. Como já afirmaram outros importantes comentadores, como François Delaporte e Claude Debru, o artigo sobre a teoria celular, escrito apenas dois anos após o Ensaio, é o primeiro texto no qual Canguilhem reflete sistematicamente sobre a história das ciências, seus objetos e métodos:

A história das ciências recebeu até o presente momento na França mais encorajamentos do que contribuições. Seu lugar e seu papel na cultura geral não são negados, mas eles são bastante mal definidos. Seu sentido é mesmo flutuante. Deve-se escrever a história das ciências como um capítulo especial da história geral das ciências? Ou, antes, devemos pesquisar nas concepções científicas de um determinado momento uma expressão do espírito geral de uma época, uma Weltanschauung? O problema de atribuição e de competência está em suspenso. Essa história parte do historiador enquanto exegeta, filólogo e erudito (isso sobretudo para o período antigo) ou, antes, do cientista especialista, apto a dominar enquanto cientista o problema do qual ele retraça a história? ${ }^{61}$

Canguilhem segue fazendo questões cada vez mais incisivas: devemos rastrear até os começos uma questão científica e fazer a história como o progresso daquela questão até sua forma atual? Ou basta encontrarmos um documento ou ideia ultrapassada, velha, para dizermos que fazemos história? Qual seria o valor para as ciências de uma história das ciências assim elaborada? A história das ciências não estaria, então, reduzida a um museu de horrores, no qual são exibidos apenas os erros cometidos no passado, antes que a verdade científica viesse à luz? Em outro texto, de 1966, Canguilhem lembrou a famosa imagem de Pierre Lafitte, discípulo de Auguste Comte e professor de História das Ciências no Collège de France no final do século XIX, para quem a história das ciências seria um "microscópio mental". Para Canguilhem, a imagem do microscópio é ideal para explicar o pensamento positivista e a forma como se estabeleceu nas instituições de ensino e pesquisa francesas: "encontramos um pressuposto positivista na ideia que a história é apenas uma injeção de duração na exposição dos resultados científicos. O microscópio procura o crescimento de um desenvolvimento dado sem ele, ainda que visível apenas por ele",62.

Naquela entrevista a François Proust, desconhecida, durante décadas, para a quase totalidade dos leitores de Canguilhem, ele é questionado sobre as razões para aquela avaliação

\footnotetext{
${ }^{60}$ LIMOGES, "L'épistémologie historique dans l'itinéraire intellectuel de Georges Canguilhem", p. 65.

${ }^{61}$ CANGUILHEM, La connaissance de la vie, pp.53-54

${ }^{62}$ CANGUILHEM, “L'objet de l'histoire des sciences", p. 12-13.
} 
lamentável, e particularmente francesa, de que a história das ciências teria recebido mais encorajamentos do que contribuições. Mais de vinte anos já haviam se passado no momento em que Canguilhem era chamado a prestar contas, mas sua opinião não havia mudado. E, na resposta a Proust, Canguilhem estende seu diagnóstico à história da medicina. A ampla difusão e recepção dos trabalhos de Canguilhem e Foucault, mas também de Delaporte, Jacques Léonard ou Mirko Grmek, podem passar, ao leitor brasileiro, a impressão de que a história da medicina é uma disciplina de primeiro escalão na França. É desconcertante para o leitor brasileiro perceber que $O$ nascimento da clínica, um desses livros que parecem ter nascidos clássicos, foi sistematicamente ignorado na França no momento do seu lançamento e permanece o livro menos lido de Foucault. Canguilhem deposita sobre o positivismo a responsabilidade sobre essa infeliz situação. Para ele, a história da medicina conheceu um grande prestígio no século XIX graças ao positivismo, mas a geração seguinte foi responsável pelo seu aniquilamento. Isso porque, segundo Canguilhem, os discípulos do Positivismo esqueceram que ele era, originalmente, a colocação em perspectiva histórica das aquisições científicas. "A partir do momento em que identificamos o estado positivo a um estado definitivo do espírito humano, tem-se a impressão de que o período da história terminou e não nos interessamos mais pela história", afirmou ${ }^{63}$. E, ele continua, "se esquecemos que o Positivismo é uma lei de progresso, e se identificamos o progresso ao último dos seus valores e não à passagem de um valor ao outro, a partir desse momento a história não tem nenhum interesse porque acreditamos estar na terra prometida da verdade científica”.

Foi no texto sobre a teoria celular que Canguilhem vibrou a clava demolidora contra essa concepção dogmática de ciências, mais ainda, contra "uma concepção dogmática da cultura científica, uma concepção dos 'progressos do espírito humano' que é aquela da Aufklärung, de Condorcet, de Comte" ${ }^{, 64}$. É essa concepção dogmática da cultura científica que fundamenta o preconceito segundo o qual aquilo que foi dito no passado está errado, segundo o qual a anterioridade cronológica é sinônimo de inferioridade lógica. É essa tese positivista que, como lembra Canguilhem, sustenta as páginas de história das ciências da famosa Introduction à la médecine experimentale de Claude Bernard, onde lemos que "a ciência do presente está portanto necessariamente acima da ciência do passado, e não há razão para buscar um crescimento da ciência moderna nos conhecimentos dos antigos." Ainda segundo Claude Bernard, "as teorias dos antigos, necessariamente falsas, pois abarcam os fatos descobertos desde então, não poderiam ter nenhum benefício real para as ciências atuais" ${ }^{\prime \prime}$. O artigo "A teoria celular" é apenas o primeiro dos textos de Canguilhem onde essa tese positivista será denunciada. De fato, seu objetivo é

\footnotetext{
${ }^{63}$ CANGUILHEM, "La médecine et son histoire" [s.p.].

${ }^{64}$ CANGUILHEM, La connaissance de la vie, p. 54

${ }^{65}$ BERNARD, Introduction à la médecine experimentale, p. 235.
} 
restituir uma dignidade teórica ao pré-científico, como bem notou François Delaporte. Esse objetivo implica a tomada de três decisões.

A primeira delas, consiste em "reabilitar os mitos e imagens de modo a lhes conferir uma função heurística. Se livrar, portanto, da ideia segundo a qual o saber se forma pela rejeição

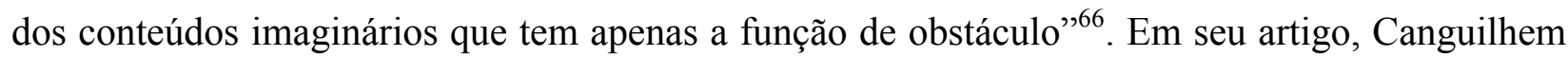
mostrará a continuidade que certos objetos biológicos mantêm com a sua imagem primeira, como a célula, um objeto biológico afetivamente determinado. A palavra célula (cellule) evoca (em francês), a imagem da abelha, dos alvéolos. Canguilhem argumentará que a associação consciente entre a célula e o alvéolo, feita por autores como Haeckel, favoreceu a associação inconsciente entre o trabalho coletivo da colmeia e o próprio organismo. Assim, para Canguilhem, é preciso considerar, na história da teoria celular ${ }^{67}$, os "valores afetivos e sociais de cooperação e de associação" que determinam as diferentes elaborações discursivas sobre a ideia de uma composição elementar do ser vivo. Buffon, naturalista francês setecentista, buscou revigorar o mecanicismo cartesiano a partir do estudo das "maravilhas" das colmeias, às quais comparou os organismos complexos: "uma aglomeração física ordenada pela natureza e independente de toda visão, de todo conhecimento, de todo raciocínio" "68.

A segunda decisão fundamental para o investimento de dignidade teórica ao précientífico consistirá em destacar a significação das construções discursivas a partir de seu núcleo positivo, rompendo com a ideia de que a ciência se situa num espaço distinto daquilo que ainda não é científico. Assim, é preciso incluir na história da teoria celular a tentativa de Buffon de reduzir os seres vivos a uma unidade viva fundamental, ainda que, para Canguilhem, essa tentativa não passasse de um "sonho teórico" para o atendimento de exigências especulativas de certos fatos de reprodução e hereditariedade. Os corpos organizados, conforme Buffon explicou em Histoire des animaux, de 1748, "são compostos de outros corpos orgânicos semelhantes, dos quais discernimos a olho nu a quantidade acumulada, mas dos quais só podemos perceber as partes primitivas por meio do raciocínio" (Buffon não era um entusiasta do microscópio) ${ }^{69}$. Para ele, essa ideia de uma composição elementar do ser vivo permitiria resolver, teoricamente, as dificuldades encontradas por teorias rivais para explicação dos fenômenos de reprodução, como o ovismo, que admite uma hereditariedade materna, e o animalculismo, que defende uma hereditariedade paterna. Leitor de Maupertuis, atento à sua preocupação com a produção de

\footnotetext{
${ }^{66}$ DELAPORTE, "La problématique historique et la vie”, p. 223.

${ }^{67}$ CANGUILHEM, Op. cit., p. 50.

${ }^{68}$ CANGUILHEM, Op. cit., p. 71.

${ }^{69}$ Ibidem, p. 65
} 
variedades acidentais exposta em Vénus physique, de $1745^{70}$, Buffon defendia que apenas a hereditariedade bilateral poderia explicar os fenômenos de hibridação, através da agregação por atração de moléculas orgânicas segundo uma lei de constância morfológica batizada de "molde interior". Não é difícil deduzir que essa "agregação por atração" derivava da recepção entusiasmada das ideias de Newton por Buffon. "Uma teoria biológica nasce do prestígio de uma teoria física”, avalia Canguilhem ${ }^{71}$.

Por fim, novamente nas palavras de François Delaporte a propósito da dignidade teórica do pré-científico, trata-se, no artigo de Canguilhem sobre a teoria celular, de "deixar para trás a ideia segundo a qual a recorrência deve servir para operar a separação entre o verdadeiro e o falso". Para Canguilhem, os obstáculos, os limites da capacidade de explicação dos fenômenos por uma teoria são fundamentais para o futuro dessa teoria. Porém, mais importante é a tendência inaugurada por essa teoria, a tendência que começa a "criar a atmosfera intelectual de uma geração de pesquisadores" 72 .

Quando o naturalista de Montbard [Buffon] procurava "o único recurso e o único sujeito" utilizados pela natureza para se diversificar em viventes complexos, ele ainda não podia saber que buscava aquilo que os biólogos do século XIX chamaram de célula. E aqueles que encontraram na célula o elemento último da vida, sem dúvida esqueceram que realizavam um sonho, mais do que um projeto de Buffon. Mesmo os sonhos dos sábios conhecem a persistência de um pequeno número de temas fundamentais. Assim, o homem reconhece facilmente seus próprios sonhos nas aventuras e sucessos de seus semelhantes. ${ }^{73}$

Para Delaporte, nesse momento Canguilhem oscila entre duas posições em história, como resultado de uma dificuldade encontrada na elaboração de sua técnica histórica. Poderíamos dizer que se trata de um problema teórico posto para a prática da história das ciências quando aproximada da história das ideias: afinal, como fazer entrar, na história de uma ciência, as imagens, os mitos, os "sonhos teóricos", sem deixar de reconhecer a diferença entre ciência e não-ciência? Como equilibrar a tensão entre continuidade e descontinuidade? Como fazer entrar na história das ciências aquela ideia que já havíamos destacado do Ensaio, segundo a qual "antes da ciência, são as técnicas, as artes, as mitologias e as religiões que valorizam espontaneamente a vida humana"? Ou, nas palavras de Delaporte, "como pensar o entrelaçamento e a separação

\footnotetext{
${ }^{70}$ Sobre Maupertuis, conferir o livro de Maurício de Carvalho Ramos, A geração dos corpos organizados em Maupertuis (São Paulo: Editora 34, 2009).

${ }^{71}$ CANGUILHEM, Op. cit., p. 71.

${ }^{72}$ Ibidem, p. 72, grifo nosso.

${ }^{73}$ Idem.
} 
daquilo que Bachelard distinguia como história das ciências perimida e história das ciências sancionada?" 74

Lembremos que, na primeira metade do século, um dos principais argumentos em defesa da história das ciências como disciplina autônoma era o interesse que ela poderia ter para a prática científica, um argumento que encontrava seus principais defensores entre os membros do Centre de Synthèse, do qual Bachelard era um assíduo frequentador, tomando parte nos debates sobre a situação e os projetos para a disciplina na França. A noção de recorrência foi a contribuição de Bachelard para a defesa da atualidade e da relevância científica da história das ciências. Ela atribui uma função à história das ciências na cultura científica. Embora essa ideia de uma história escrita a partir dos problemas da ciência atual apareça cedo nos textos de Bachelard, a elaboração daquela divisão entre história sancionada e história perimida é de 1951, portanto cinco anos após a primeira publicação do artigo de Canguilhem sobre a teoria celular. Aquelas noções aparecerão no trabalho de Canguilhem apenas em 1955, no livro sobre a formação do conceito de reflexo nos séculos XVII e XVIII. Publicado apenas três anos após o Ensaio, o artigo sobre a teoria celular rearranja a preocupação com as razões históricas que permitiram, num determinado momento da cultura intelectual de uma civilização, o aparecimento de certas questões, mesmo aquelas que vieram a se comprovar falsas. Isso porque, e esse é um dos grandes méritos da leitura que Canguilhem faz da preocupação de Bachelard pela história do presente, nada permite dizer que a verdade atual não virá a se apresentar como erro.

O benefício de uma história das ciências, é claro, parece-nos ser o de revelar a história na ciência. A história, em nossa opinião, quer dizer o sentido da possibilidade. Conhecer é menos ir de encontro a um real do que validar um possível tornando-o necessário. Desde então, a gênese do possível importa tanto quanto a demonstração do necessário. A fragilidade de um não o priva de uma dignidade que viria ao outro por sua solidez. A ilusão poderia ser uma verdade. A verdade se revelará, um dia, talvez, ilusão. ${ }^{75}$

Parece-nos, portanto, que Delaporte tem toda a razão ao afirmar que Canguilhem está preocupado com a relação entre verdadeiro e falso na história das ciências no artigo de 1946, mas é por uma leitura retrospectiva que ele articula essa preocupação de Canguilhem a partir das noções bachelardianas de recorrência, história sancionada e história perimida. Aqui, o erro denunciado de uma teoria, resolve apenas o problema da sua permanência discursiva, não o da persistência da tendência que ela inaugura. Em "A teoria celular", Bachelard tem para Canguilhem a função de uma fonte de inspiração para a elaboração de "uma concepção de

\footnotetext{
${ }^{74}$ DELAPORTE, Op. cit., p 227

${ }^{75}$ CANGUILHEM, La connaissance de la vie, p. 52.
} 
ciência", melhor dizendo, de "um método de cultura na história científica". A "psicologia da conquista progressiva das noções [científicas] em seu conteúdo atual” que, nos primeiros textos de Bachelard, como La formation de l'esprit scientifique e La psychanalyse du feu, de 1938, assume o papel de uma história das ciências, despertou em Canguilhem o interesse pela sobredeterminação afetiva dos objetos científicos: "Escolhemos, como primeiro ensaio dessa ordem, a teoria celular em biologia", esclareceu.

Leituras menos preocupadas com a interpretação de Canguilhem a partir de uma epistemologia descontinuísta poderiam explorar de outra maneira algumas das propostas da técnica história empregada para o estudo da teoria celular, sem necessariamente esbarrar na dificuldade teórico-metodológica da recorrência representada pela inclusão das imagens e dos mitos na história positiva de uma ciência. Como exemplo recente, citamos o artigo "O conceito epistemológico histórico de nostoc a partir de uma leitura indiciária de A teoria celular de George Canguilhem", de Maurício de Carvalho Ramos. Francamente continuísta, em sua "leitura indiciária" de Canguilhem, Ramos toma como orientação metódica plena aquilo que, em "A teoria celular", aparece apenas como uma conjectura: "Os conceitos em mutação no interior das culturas científicas concebidos no estilo epistemológico histórico estão sempre enxertados com imagens míticas, desde que corretamente valorizadas como ingredientes indispensáveis para satisfazer intenções intelectuais" ${ }^{76}$. A expressão "cultura científica" não é estranha a Canguilhem (ou a Bachelard) e já havíamos feito uso dela nesse mesmo capítulo. Lembremos que Canguilhem denunciou como dogmática a concepção (aquela de Condorcet, Comte e da Aufklärung) de cultura científica como resultado de um processo de depuração. No artigo de Ramos, a partir de elementos destacados de "A teoria celular", encontramos uma definição de cultura científica como sendo "o cenário em que sobrevivem as intenções intelectuais encarnadas como história metamórfica de conceitos".

O leitor de Canguilhem que se acostumou a interpretá-lo como um pensador da descontinuidade provavelmente terá dificuldade em reconhecer nessa definição uma inspiração canguilhemiana, mas Ramos defende bem o seu caso. Para ele, as culturas científicas mais interessantes são aquelas em que mito e ciência se articulam internamente, de modo permanente. Notamos uma escolha estética dos objetos dessa história das ciências, não em detrimento do valor que essa história poderia ter para a ciência atual, mas ao lado desse valor, afinal, é a articulação entre mito e ciência que permite não apenas a "abertura" e a "plasticidade", mas também a "longevidade" de uma cultura científica. A leitura indiciária proposta por Ramos consiste em

\footnotetext{
${ }^{76}$ RAMOS, "O conceito epistemológico histórico de nostoc a partir de uma leitura indiciária de $A$ teoria celular de George Canguilhem", p. 117.
} 
tomar o texto "com inúmeras leituras possíveis, cada qual singularizada pelos sinais e pistas que o leitor identifica em função de sua investigação particular". No entanto, como o artigo sobre a teoria celular traz apenas as primeiras elaborações teórico-metodológicas de Canguilhem a propósito da história das ciências, pode-se suspeitar que seria prematuro transformar essas conjecturas em opção metódica. Tal procedimento parece abrir a guarda para a acusação de que a "leitura indiciária" seria, na verdade, uma "leitura prematura", um recorte das ideias de Canguilhem, que desconsideraria o desenvolvimento da sua obra e eventuais mudanças na sua concepção da relação entre ciência e mito. Contra tais argumentos, vale a pena conhecer a opinião recente de Claude Debru, outro ex-aluno de Canguilhem, sobre o artigo "A teoria celular".

Debru, que não pratica a leitura indiciária, mas pretende compreender a obra de Canguilhem a partir de sua estrutura argumentativa interna, reforça nossa tese sobre a presença, desde a década de 40, de uma preocupação teórica sobre as relações entre história das ciências e história das ideias nos escritos de Canguilhem, ao mesmo tempo em que libera o tema da relação entre ciência e não-ciência de certas interpretações sedimentadas pela fortuna crítica (para a qual ele mesmo havia contribuído em outros tempos):

\begin{abstract}
Vemos se formar nesse trabalho bastante seminal de Canguilhem sobre a teoria celular uma prática da epistemologia sobre a qual, me parece, certos intérpretes de Canguilhem (eu me incluo) não insistiram suficientemente. A história das teorias e dos conceitos, que formará a vulgata da epistemologia histórica, que nos ensina que as teorias nascem de teorias preexistentes, não pode se dissociar do exercício da imaginação teórica. O que se passa antes do famoso corte epistemológico é tão importante quanto o que se passa depois. Porém o mais essencial do texto sobre a teoria celular não é seu conteúdo epistemológico. Ele se encontra na constatação da conexão e da circulação das ideias. A ciência, nesses textos, não aparece como um processo fechado, uma hiperespecialização cada vez mais minúscula. As ideias científicas, a filosofia das ideias científicas (mais até que a filosofia das ciências, expressão que eu nunca compreendi muito bem) estão em comunicação direta com muitos outros domínios que aqueles domínios de pertinência direta. ${ }^{77}$
\end{abstract}

A leitura indiciária não pretende coincidir com a "filosofia do autor", mas permitiu que Ramos identificasse elementos durante muito tempo negligenciados da obra de Canguilhem e que só agora começam a ser trazidos à luz pelos seus comentadores mais atentos. É evidente que tal leitura também não pode estar em contradição com a letra do autor ou simplesmente abandonar aspectos fundamentais de seu pensamento. No caso de Canguilhem, a principal dificuldade da aproximação entre história das ciências e história das ideias residiria no privilégio que ele atribui

\footnotetext{
${ }^{77}$ DEBRU, “Épistémologie historique et/ou Histoire épistémologique?”, p. 115.
} 
aos conceitos científicos e a função que eles desempenham em sua epistemologia. No prefácio ao livro Ideologia e racionalidade na história das ciências da vida, por exemplo, Canguilhem dizia não se importar em ser acusado de "fóssil conceitual" por conta da sua indiferença diante da gestação, em meados dos anos 70, de uma nova história das ciências que, em vez de se interessar, como ele, pela separação entre ciências e ideias, entre ciência e literatura, se voltava para a sua intussuscepção mútua. Quer dizer, os conceitos, na obra de Canguilhem, servirão à defesa de uma certa concepção de descontinuidade em história. E, no entanto é justamente a história do conceito de célula que está no centro da revalorização da circulação das ideias, da filosofia das ideias científicas, das tendências e das intenções intelectuais, enfim, da cultura científica na obra de Canguilhem.

Em "A teoria celular", Canguilhem afirma que "os fatos suscitam as teorias, mas não engendram os conceitos que as unificam interiormente, nem as intenções intelectuais desenvolvidas por elas". Ramos desmembra essa afirmação em duas proposições centrais para a construção de um conceito de cultura científica: (1) a independência que os conceitos e as intenções intelectuais desenvolvidas pelas teorias possuem dos fatos e (2) a função atribuída aos conceitos de unificar interiormente as teorias. Sem jamais negar a diferença de qualidade entre ciência e mitologia, entre uma mensuração e um devaneio, essa relação entre conceitos, teorias e intenções intelectuais permite a Canguilhem vislumbrar a possibilidade de que "as teorias científicas, no que concerne aos conceitos fundamentais que elas fazem sustentar em seus princípios de explicação, enxertam-se em antigas imagens e, diríamos nós, em mitos"78. Canguilhem continuará dizendo, a propósito das intenções intelectuais, que elas "vêm de longe" e, a propósito dos conceitos, que eles "são em número pequeno". Por essa razão, ele explica, “os temas teóricos sobrevivem à sua destruição aparente que uma polêmica e uma refutação se gabam de haver obtido" 79 . Daí a terceira proposição determinante para um conceito de cultura científica, (3) a sobrevivência dos temas teóricos diante dos processos de crítica e refutação científicas. "Em conjunto", afirma Ramos, essas proposições "contêm um sentido específico da autonomia cognitiva e histórica que os conceitos possuem em relação às teorias." ${ }^{~} 80$

Inversamente, a ideia de "incomensurabilidade das teorias científicas", tipicamente inglesa, que durante algum tempo pareceu ameaçar os ideais de objetividade e racionalidade científica, seria impossível sem a perspectiva historiográfica centrada nas teorias, que atribuía um papel subalterno aos conceitos. Segundo Gary Gutting, a melhor explicação para esse fato de cultura é a inexistência de distinção, para os filósofos anglo-americanos, entre interpretação e

\footnotetext{
${ }^{78}$ CANGUILHEM, La connaissance de la vie, p. 52.

${ }^{79}$ Ibidem, p. 53

${ }^{80}$ RAMOS, Op. cit., p. 116.
} 
teoria. É verdade que Bachelard e Canguilhem, muito antes de Hanson e Kuhn, já haviam dito que não existem dados puros, que nós só tomamos conhecimento do real como interpretação. Entretanto, para os anglo-americanos, "a interpretação de um dado é uma questão de entendê-lo em termos de uma teoria, isto é, em termos de um conjunto de generalizações científicas apresentadas para explicar o fenômeno investigado" ${ }^{\text {}}$. Gutting ainda explica que, sob essa perspectiva, que é a de Feyerabend, por exemplo, os conceitos a partir dos quais os dados são interpretados derivam das teorias pelas quais eles são explicados, ou seja, não apenas os conceitos só teriam sentido no interior das teorias, como qualquer mudança na teoria exigiria uma imediata reformulação do conceito.

Canguilhem se insurgirá contra essa perspectiva centrada nas teorias científicas que caracterizou por muito tempo a escrita da história das ciências nos países de língua inglesa, mas que também era comum na França na primeira metade do século passado. Para ele, os conceitos se instauram num ponto mais profundo que as teorias.

\section{A história dos conceitos}

Foi sobretudo a partir de La formation du concept de réflexe aux XVIIe et XVIIIe siècles, de 1955, que Canguilhem passou a refletir sistematicamente sobre essa nova forma de escrever a história das ciências enquanto história dos conceitos científicos. Canguilhem afirmou que o problema geral em História das Ciências é a ideia de que "um conceito não pode aparecer senão no contexto de uma teoria ou, pelo menos, numa inspiração heurística homogênea àquelas em que os fatos de observação correspondentes serão interpretados posteriormente". E nesse livro, a reflexão sobre as relações entre os conceitos e as teorias aparece, enfim, emoldurada por aquelas noções bachelardianas:

É possível (...) que haja, em biologia, uma história da ciência que faça sua justa posição frente ao que o Sr. Bachelard chama de "passado atual", que não seja exclusivamente a paleontologia de um espírito científico desaparecido, que tente ressuscitar em sua vitalidade original os elementos daquilo que o mesmo autor chama de história sancionada. Ao escrever a história da formação, durante os séculos XVII e XVIII, do conceito de reflexo, nós pretendemos contribuir com a constituição, no que concerne à biologia, daquilo que nós chamamos, com o $\mathrm{Sr}$. Bachelard, "uma história recorrente, uma história que nós podemos esclarecer pela finalidade do presente", sem por isso, não mais que ele mesmo, pregar pelo

\footnotetext{
${ }^{81}$ GUTTING, Michel Foucault's archaeology of scientific reason, p. 33
} 
retorno às mentalidades pré-científicas e, no caso, às práticas de taumaturgia médica. ${ }^{82}$

Vale a pena, antes de continuarmos a falar dos conceitos, nos determos brevemente sobre essa ideia de atualidade que emoldura a questão continuidade/descontinuidade em história das ciências. Explicamos, no primeiro capítulo, que apesar das críticas de Canguilhem à concepção dogmática de cultura científica herdada da Aufklärung, entendemos que a noção de atualidade aproxima Bachelard, Canguilhem e Foucault do projeto filosófico da modernidade inaugurado pela Crítica kantiana. Explicamos que Foucault define a modernidade como um êthos, uma atitude, um modo de relação que concerne à atualidade e que a principal característica dessa atitude é a reflexão sobre a atualidade como diferença na história, que, por um lado, permite o surgimento de uma consciência da descontinuidade do tempo: ruptura da tradição, sentimento de novidade, vertigem do que se passa e, por outro, determina um modo de relação que é preciso estabelecer consigo mesmo.

No livro de 1951 em que apresenta suas considerações sobre as duas histórias, isto é, a sancionada e a perimida, L'activité rationaliste de la physique contemporaine, Bachelard também articula as relações entre modernidade e atualidade na história das ciências: "o ponto de vista moderno determina, então, uma nova perspectiva sobre a história das ciências, perspectiva que põe o problema da eficácia atual dessa história das ciências na cultura científica", afirmou. “Trata-se", ele continua, "de mostrar a ação de uma história julgada, uma história que se impõe a tarefa de distinguir o erro e a verdade, o inerte e o ativo, o nocivo e o fecundo" ${ }^{\wedge 3}$. No mesmo ano de 1951, em conferência pronunciada no Palais de la Découverte intitulada "L'actualité de l'histoire des sciences" Bachelard declarou: "De fato, meu projeto é procurar em quais condições e sob que forma a história das ciências pode ter uma ação positiva sobre o pensamento científico de nosso tempo" ${ }^{\prime 84}$. De volta a L'activité rationaliste de la physique contemporaine, notamos que esse projeto provocou uma cesura entre a história das ciências e a história social. Pois, para Bachelard, na história social o historiador deveria procurar apagar seu olhar, o ponto de onde olha, pois não há hierarquia de valores consensualmente reconhecida que permita jugar o passado. Em relação às ciências, diz Bachelard, o julgamento do passado não é simplesmente possível, mas altamente desejado se se quiser atribuir à história das ciências mais que uma função anedótica. "Para o pensamento científico, o progresso é demonstrado, ele é demonstrável, sua demonstração é um elemento pedagógico indispensável para o desenvolvimento da cultura

\footnotetext{
${ }^{82}$ CANGUILHEM, La formation du concept de réflexe aux XVIIe et XVIIIe siècles, p. 166-167

${ }^{83}$ BACHELARD, L'activité rationaliste de la physique contemporaine, p. 24.

${ }^{84}$ BACHELARD, "L'actualité de l'histoire des sciences", p. 138
} 
científica", escreveu Bachelard. "Dito de outra forma, o progresso é a própria dinâmica da cultura científica, e é essa dinâmica que a história das ciências deve descrever" ${ }^{2}$.

Ora, embora Canguilhem admita pretender realizar, em biologia, uma "história recorrente", segundo a definição bachelardiana, isto é uma história que se possa esclarecer pela finalidade do presente, diríamos que existem diferenças consideráveis entre suas análises. A primeira dessas diferenças diz respeito ao papel da história das ciências na cultura científica. Embora essa noção de "cultura científica" seja, em Bachelard, mais ampla que uma cultura compartilhada entre uma comunidade científica - ela envolve, por exemplo, a transmissão do conhecimento científico nas escolas e até mesmo a formação moral dos indivíduos, posto que, para Bachelard, a moral é parte da razão constituída - seu objetivo principal ainda é determinar como a história das ciências pode ser útil para as ciências. É da demonstração do "passado atual", isto é, da história (sancionada) daqueles conceitos vivos nos discursos científicos contemporâneos, que a história das ciências, essa nova disciplina recém-liberada da filosofia, retiraria sua dignidade (que, no século XIX, repousava na demonstração da doutrina da perfectibilidade do Espírito).

Canguilhem não adotará o mesmo procedimento. Já no Ensaio de 1943 Canguilhem explica que, ao integrar à especulação filosófica alguns dos métodos e aquisições da medicina, seu objetivo não era dar lições ou dirigir qualquer julgamento normativo sobre a atividade médica: "Se a medicina deve ser renovada, cabe aos médicos fazê-lo, por sua própria honra e risco" ${ }^{\text {86 }}$. Já no artigo "Aspectos do vitalismo", que compõe o livro $O$ conhecimento da vida, Canguilhem afirma que "não se trata de defender o vitalismo de um ponto de vista científico; o debate só concerne autenticamente aos biólogos. Trata-se de compreendê-lo de um ponto de vista filosófico" ${ }^{87}$. Diferente de Bachelard, a preocupação com a atualidade não partirá do conteúdo de uma determinada teoria ou conceito científico, mas da atualidade do efeito de uma teoria sobre a cultura científica. Essa diferença explica porque, para Bachelard, as intuições vitalistas constituíram um obstáculo epistemológico para a edificação do pensamento científico, ao passo que Canguilhem se preocupou em demonstrar, historicamente, a "vitalidade do vitalismo".

A opinião de Bachelard de que o vitalismo seria uma ilusão do pensamento era compartilhada por muitos cientistas. "Vitalista", diz Canguilhem, é uma palavra de tom pejorativo, frequentemente utilizada como injúria entre os círculos mais eruditos das ciências. No entanto, para Canguilhem, a necessidade atual de refutar o vitalismo, "essa denúncia de seu

\footnotetext{
${ }^{85} \mathrm{BACHELARD,} \mathrm{L'activité} \mathrm{rationaliste} \mathrm{de} \mathrm{la} \mathrm{physique} \mathrm{contemporaine,} \mathrm{p.} 24$

${ }^{86}$ CANGUILHEM, Le normal et le pathologique, p. 8.

${ }^{87}$ CANGUILHEM, La connaissance de la vie, p. 93.
} 
caráter ilusório convoca, longe de interditá-la ou fechá-la, a reflexão filosófica" ${ }^{\text {" }}$. Vemos aí o cerne da postura filosófica de Canguilhem, para quem a tarefa da filosofia era a de reabrir os problemas, e não a de encerrá-los. "A filosofia”, ele escreveu, acompanhando Léon Brunschvicg, "é a ciência dos problemas resolvidos". A necessidade que os cientistas ainda têm de refutar o vitalismo demonstra, para Canguilhem, que o vitalismo não é uma ilusão da mesma ordem que o flogístico e o geocentrismo, mas uma ilusão com vitalidade própria no pensamento científico, posto que não encerrada nos seus enunciados. E como, em função da tendência que o vitalismo inaugurou no século XVIII, a designação de vitalista é dirigida "a toda biologia preocupada com sua independência, no que concerne às ambições anexionistas das ciências da matéria", para Canguilhem, "compreender a vitalidade do vitalismo é engajar-se em uma pesquisa do sentido das relações entre a vida e a ciência em geral, a vida e a ciência da vida mais especialmente. ${ }^{" 89} \mathrm{E}$ uma das formas que essa preocupação com a racionalidade específica das ciências da vida em relação com esse objeto de conhecimento assumirá na obra epistemológica de Canguilhem é justamente a história dos conceitos.

Em La formation du concept de réflexe aux XVIIe et XVIIIe siècles, Canguilhem questiona a atribuição da formulação do conceito de reflexo ao filósofo René Descartes. Para a historiografia científica corrente, Descartes teria dado uma explicação mecanicista do fenômeno conhecido como "movimento reflexo". Porém, segundo Canguilhem, Descartes não formula nem o termo, nem o conceito de reflexo, pois sua característica principal é que ele não procede de um órgão central, enquanto em Descartes o movimento reflexo é produzido pelo espírito animal a partir do cérebro (ou do coração, que seria a fonte de todo movimento corporal). Para Canguilhem, as fontes da interpretação equivocada de que Descartes teria introduzido o conceito de reflexo são, primeiro, a confusão da identificação e descrição de um fenômeno com a sua interpretação conceitual específica e, em seguida, a falta de clareza na distinção entre história das teorias e história dos conceitos. Equívoco amplamente reforçado por uma razão ideológica, nacionalista: um dos grandes responsáveis pela fixação dessa interpretação foi o alemão Du Bois Reymond, que, no século XIX, pretendeu minimizar o trabalho experimental do fisiologista tcheco Georg Prochaska alegando que ele nada fazia senão retomar a concepção mecanicista cartesiana.

O conceito de reflexo desempenhou um papel fundamental nas teorias mecanicistas do organismo, o que conduziu os cientistas que veem na história das ciências uma sucessão de teoria à fácil interpretação de que a descrição do movimento reflexo por uma teoria mecanicista

\footnotetext{
${ }^{88}$ CANGUILHEM, La connaissance de la vie, p. 98.

${ }^{89}$ Idem.
} 
era equivalente à formulação do conceito de reflexo por essa mesma teoria. Ora, conforme Canguilhem, o conceito de "reflexo" só pôde surgir graças ao vitalismo, com a figura do físico inglês Thomas Willis no século XVII, que entendia a vida como luz. Temos aqui, novamente, a força das imagens: foi por ver a vida como luz que Willis recorreu às leis da ótica para explicar o movimento involuntário. A compreensão do motus reflexus como refração da luz articulou, a partir da obra de Willis, os dois elementos centrais do conceito de reflexo, a saber, a distinção do cerebelo, como centro do movimento involuntário, do cérebro, como centro do pensamento racional e ação voluntária.

Em seu livro, Canguilhem mostrou como o conceito vitalista de reflexo proposto por Willis pôde se generalizar, se enriquecer experimentalmente e alcançar sucesso efetivo numa explicação mecanicista da vida animal. Delaporte explica magistralmente bem essa solução dada por Canguilhem, em La formation du concept de réflexe, para o problema do entrelaçamento e da separação entre o sancionado e o perimido em história das ciências:

[Canguilhem] estabelece que uma mitologia pode contribuir à formação de um conceito e tombar fora de uma ciência. Ele faz uma distinção entre uma teoria que autoriza a formação de um conceito (aquela de Willis) e uma teoria que forma a sua tela (aquela de Descartes). Além disso, ele mostra que a segunda pode desempenhar um papel positivo no desenvolvimento ulterior do saber. É assim que, trabalhando nessa região média, que está a meio caminho das teorias e dos objetos, ele pode reorientar as teorias vitalistas em direção do objeto a fim de sublinhar a atualidade de seu objetivo e inatualidade de seu conteúdo. ${ }^{90}$

A inatualidade de seu conteúdo e a atualidade de seu objetivo, de sua tendência ou de sua intenção intelectual, poderíamos dizer. Não obstante, a descontinuidade está devidamente instaurada no pensamento canguilhemiano.

Como dissemos, essa importante contribuição teórica para a historiografia das ciências, a história dos conceitos, foi destacada por Macherey em "La philosophie de la science de Georges Canguilhem. Épistémologie et histoire des sciences”, repetimos, a primeira análise sistemática do pensamento de Canguilhem, amplamente difundida, em parte graças à apresentação de Louis Althusser. O texto de Macherey tem o grande mérito de avaliar o significado da história dos conceitos para a transformação de uma compreensão dos progressos das ciências que seguia pelo encadeamento das teorias, um modo de proceder tipicamente idealista: "enquanto o caminho da história real vai do conceito ao fenômeno através de duas mediações estreitamente solidárias - experimentação e teoria -, a história vista pelos cientistas

\footnotetext{
${ }^{90}$ CANGUILHEM, La formation du concept de réflexe aux XVIIe et XVIIIe siècles, p. 225.
} 
funda-se em uma concepção hierárquica dos níveis, da observação à teoria" ${ }^{91}$. Para Macherey, substituir o encadeamento das teorias pela filiação dos conceitos significa pensar a ciência a partir de seu corpo real - os conceitos - e não em sua legalidade ideal - a dependência lógica entre teorias, das mais simples às mais acabadas, para explicação de um determinado fenômeno. "Se o conceito está do lado das questões, a teoria está do lado das respostas. Partir do conceito é escolher partir das questões para se escrever a história", afirmou ${ }^{92}$.

Macherey distinguiu nesse procedimento de Canguilhem dois momentos essenciais: o nascimento de um conceito e o momento em que ele acende à sua consistência própria. São esses dois momentos que determinariam a formação de um conceito, como aquele de reflexo ${ }^{93}$. $\mathrm{O}$ tema do nascimento de um conceito, explica Macherey, diz respeito a um modo de pensar científico que independe de qualquer elaboração teórica. Daí que o conceito de reflexo possa ter nascido no interior de uma doutrina de inspiração vitalista e depois tenha sido transposto para uma teoria mecanicista. "O nascimento de um conceito é, portanto, um começo absoluto: as teorias, que são como que a 'consciência' dele, não vêm senão depois, e muitas excrescências teóricas podem-se enxertar em um mesmo conceito". Macherey chamou de "aventura do conceito" a passagem do conceito de uma teoria a outra. Essa polivalência teórica que Canguilhem enxerga nos conceitos, e que determina o tema consistência, é tributária, em nossa opinião, da sua leitura de Bachelard. Encontramos já no primeiro livro de Bachelard, o Essai sur la connaissance approchée, de 1927, a ideia de que os conceitos dão a primeira formulação racional de um fenômeno, a partir de onde serão construídas as teorias para explicá-lo, permitindo, inclusive, que teorias concorrentes se valham do mesmo conceito. E "cada vez que um conceito é integrado num juízo ele se diversifica", ele explica. "E como o conceito é obrigado a integrar-se num juízo, é um abuso de lógica que nos leva a considerá-lo como um elemento inteiro fechado sobre si, como se sua função não pudesse reagir sobre sua composição. Apresentar um conceito isolado não é pensar" $" 94$.

Para Canguilhem, assim como para Bachelard, os conceitos se instauram num ponto mais profundo que as teorias. O conceito é "um nome carregado de um sentido, capaz de cumprir uma função de discriminação na interpretação de certas observações ou experiências", escreveu Canguilhem no livro sobre o conceito de reflexo ${ }^{95}$. De um ponto de vista historiográfico, no entanto, a aventura dos conceitos, sua integração em novos juízos, assume, na obra de Bachelard,

91 MACHEREY, "La philosophie de la science de Georges Canguilhem. Épistémologie et histoire des sciences", p. 144.

${ }^{92}$ Ibidem, p. 148.

${ }^{93}$ Ibidem, p. 145.

${ }^{94}$ BACHELARD, Ensaio sobre o conhecimento aproximado, p. 28.

${ }^{95}$ CANGUILHEM, La formation du concept de réflexe aux XVIIe et XVIIIe siècles, p. 295 
o aspecto de um refinamento: “A conceitualização será um esforço de objetividade”, afirmou Bachelard. No entanto, essa objetividade não é determinada pelo próprio objeto de conhecimento, mas pelas exigências do espírito científico de determinada época. "É o espírito que projeta esquemas multiplicados, uma geometria, um método de construção e até um método de retificação", explicou. Assim, para Bachelard, a historicidade é um elemento determinante para objetividade do conceito e, consequentemente, para a objetividade das ciências. No entanto, e eis a diferença que nos parece mais fundamental, esse esforço de objetivação no novo espírito científico (segundo Bachelard, inaugurado pela nova Física do começo do século passado) será mensurado pelo seu grau de abstração, por uma escala de valores do sentimento racional. É a abstração que servirá de valor para o que historiador possa escrever uma história das ciências como história intelectual julgada: abstração em relação à experiência primeira e transcendência em relação ao senso comum. ${ }^{96}$

Os leitores de Bachelard familiarizados com sua obra dita "noturna" ou "poética", quando ele tentava mostrar a sobredeterminação da imaginação da matéria sobre a elaboração dos conceitos científicos, pode estranhar essa distância que afirmamos existir nas aventuras dos conceitos contadas por Bachelard e Canguilhem. Mas, em 1960, último livro de Bachelard publicado em vida, encontramos a narrativa melancólica da morte de um sonho teórico de epistemólogo, o sonho de trabalhar conjuntamente imagem e conceito:

Tendo confessado - talvez com excessiva complacência - esses pensamentos erradios que giram em torno de uma ideia fixa, essas vesânias que se multiplicam nas horas de devaneios, seja-me permitido indicar o lugar que eles ocupam na minha vida de trabalhador intelectual. Se eu tivesse de resumir uma carreira irregular e laboriosa, marcada por livros diversos, o melhor seria colocálo sob os signos contraditórios, masculino e feminino, do conceito e da imagem. Entre o conceito e a imagem, nenhuma síntese. E nenhuma filiação, sobretudo essa filiação, sempre dita, nunca vivida, pela qual os psicólogos fazem o conceito sair da pluralidade das imagens. Quem se entrega com todo o seu espírito ao conceito, com toda a sua alma à imagem, sabe muito bem que os conceitos e as imagens se desenvolvem sobre duas linhas divergentes da vida espiritual. Talvez seja bom exercitar uma rivalidade entre a atividade conceitual e a atividade da imaginação. Em todo caso, só se encontra desengano quando se pretende fazê-las cooperar. A imagem não pode fornecer matéria ao conceito. $\mathrm{O}$ conceito, dando estabilidade à imagem, lhe asfixiaria a vida. ${ }^{97}$

Não é que Canguilhem não visse a conceitualização e a passagem dos conceitos de um juízo a outro, ou de uma teoria a outra, como signos de um progresso. Em Canguilhem, a objetividade, de um conceito também é determinada pela sua historicidade. Assim, a aventura do

\footnotetext{
${ }^{96}$ BACHELARD, Loc. cit.

${ }^{97}$ BACHELARD, A poética do devaneio, p. 50.
} 
conceito será sempre um esforço de objetivação, a partir de critérios de objetividade definidos, também eles, historicamente, no interior da racionalidade específica da vida e do conhecimento sobre a vida. Por isso Foucault disse dever a Canguilhem a compreensão de que a que a história de um conceito não é a de seu refinamento progressivo, "mas a de seus diversos campos de constituição e de validade, a de suas regras sucessivas de uso, a dos meios teóricos múltiplos em que foi realizada e concluída sua elaboração" "98 . Daí, não apenas a consistência do conceito, mas a modificação na relação do conceito com as imagens e os mitos na história de seu nascimento. Afinal, a polivalência teórica retira da origem do conceito qualquer pretensão de verdade original ao mesmo tempo em que atesta, pela permanência do conceito em teorias distintas, a fecundidade de uma tendência, a pertinência de uma questão, a longevidade de uma cultura científíca.

Mas, ao fazer a escolha pelas ciências da vida e pela medicina, Canguilhem não pode adotar como medida de progresso um critério como a abstração matemática. Está evidente, por tudo que dissemos até aqui, que, para Canguilhem, o nascimento do conceito não encerra a sua história. Investigando o conceito de reflexo, Canguilhem segue a sua incorporação em diferentes teorias e propõe uma definição recapitulativa da sua formação, indicando os autores que contribuíram diretamente para a incorporação de elementos à proposta inicial de Willis sobre o movimento reflexo. Assim, em 1800,

o movimento reflexo (Willis) é aquele que, imediatamente provocado por uma sensação antecedente (Willis), é determinado segundo as leis da física (Willis, Astruc, Unzer, Prochaska), [e em relação com os instintos (Whytt, Prochaska)], pela reflexão (Willis, Astruc, Unzer, Prochaska) das impressões sensitivas em motrizes (Whytt, Unzer, Prochaska) no nivel da medula espinhal (Whytt, Prochaska, Legallois), com ou sem consciência concomitante (Prochaska). ${ }^{99}$

Porém, para Canguilhem, se em 1800 o conceito de reflexo já era um "bom conceito", ele "ainda não era bom para nada. Discute-se sobre ele, mas não sabemos nada sobre ele porque não fizemos nada com ele. Ele só está inscrito nos livros"100. Em cinquenta anos, no entanto, a situação já era bastante diferente. O conceito de reflexo deixou de ser puramente fenomenológico para se tornar fenomenotécnico, ou seja, ele passa a ser inscrito tanto nos livros quanto nos laboratórios, através de instrumentos que permitem explorar e demonstrar o fenômeno ao qual o conceito diz respeito, instrumentos que foram criados não apenas para o conceito, mas a partir dele. E, “se um conceito mais científico é, enfim, um conceito mais fenomenotécnico", diz Canguilhem, "não existe razão para limitar aos laboratórios de fisiologia o terreno sobre o qual

\footnotetext{
${ }^{98}$ FOUCAULT, A arqueologia do saber, p. 05.

${ }^{99}$ CANGUILHEM, La formation du concept de réflexe..., p. 131

${ }^{100}$ Ibidem, p. 161
} 
ele dá, em ruptura com todo verbalismo, a prova da sua validade"101. Para Canguilhem, o terreno para determinação do estatuto de cientificidade e prova de validade objetiva de um conceito elaborado no interior de uma reflexão sobre a vida não pode ser outro senão o hospital, a clínica.

Segundo Canguilhem, a importação do conceito de reflexo do laboratório para a clínica começa com as investigações de Marshall Hall, que, em 1832, introduziu o conceito de reflexo em patologia (antes ele era estuda apenas no organismo em estado normal). Assim, por exemplo, o conceito de reflexo dá provas da sua objetividade no momento em que um médico residente utiliza uma lâmpada elétrica de bolso para identificar o signo de Argyll Robertson, a abolição do reflexo pupilar diante de um estímulo luminoso (reflexo descrito por Whytt e já inscrito naquela formulação do conceito em 1800). Pouco importa se o jovem estudante de medicina não sabe o que Willis, Hall ou Whytt escreveram: a objetividade do conceito de reflexo está demonstrada desde que o clínico saiba que está utilizando a presença ou a ausência do reflexo de acomodação à luz para a elaboração de um diagnóstico da sífilis nervosa. Em suma, o reflexo existe porque o "médico trata e por vezes cura doenças do sistema nervoso cujo diagnóstico inclui, a título de sintoma, os efeitos de sua perturbação e de sua desaparição"102.

Assim, as duas teses de Canguilhem, a primeira, de 1943, em medicina, sobre o normal e o patológico, e a segunda, de 1955, em filosofia, sobre o conceito de reflexo, exploram a singularidade da história das ciências da vida em relação às histórias das outras ciências. Ali, trata-se de mostrar que a clínica (técnica) não é para a fisiologia (ciência) um "dócil serviçal" que aplica ordens intangíveis, mas que a técnica age como "conselheira e animadora" da ciência, chamando sua atenção para "os problemas concretos". Por sua vez, a tese sobre o reflexo evidencia essa tarefa, já que é ao criar os meios para demonstração experimental do conceito livresco de reflexo e, sobretudo, ao associar suas perturbações a um sintoma a partir do qual se pode estabelecer um diagnóstico e buscar uma terapêutica que o conhecimento sobre a vida se torna mais objetivo.

\footnotetext{
${ }^{101}$ Idem.

${ }^{102}$ Ibidem, p. 161
} 


\section{Capítulo 3 \\ O social por toda parte}

No capítulo anterior, mostramos como a técnica histórica que caracteriza a obra de Canguilhem começou a ser elaborada nos anos 40 e está diretamente ligada à leitura de Sigerist, não tanto pela permanência dos temas (embora os dois se interessem pelo nascimento da fisiologia), mas pela originalidade de uma forma de questionamento das ideias científicas interessada não somente pelo sucesso de uma teoria, mas pelas condições que permitiram ou determinaram o seu aparecimento num momento específico da "história intelectual da civilização". As linhas abaixo, retiradas do prefácio que Canguilhem escreveu em 1979 (portanto, depois da sua aposentadoria e da publicação de seu último livro) para o livro de François Delaporte sobre a questão da vegetalidade no século XVIII, comprovam a permanência do interesse de Canguilhem pelas condições históricas de possibilidade dos problemas científicos:

É certo que o conhecimento das estruturas e das funções vegetais deve impulsos decisivos aos botânicos do século XVIII. Todas as histórias da botânica o repetem. Mas, para a maioria, elas estão bem distantes de se interrogar sobre as razões e as circunstâncias da invenção pelos naturalistas de suas táticas ou de seus métodos. Para fazer isso, é preciso se interessar, na história de uma ciência, menos pelos seus resultados, celebrados como vitórias, que pelo modo como os problemas, mesmo aqueles não resolvidos, foram colocados. É preciso considerar a ciência como uma empreitada laboriosa de leitura dos fenômenos, dos quais as hipóteses são a grade. A gênese das hipóteses deve, então, ser privilegiada em relação ao recenseamento das observações. ${ }^{1}$

Em outro texto, publicado mais de uma década antes, Canguilhem nos informa que foi na década de 60 que ele se dedicou de modo mais sistemático a essa questão. As ocasiões para tal reflexão não fogem à regra sobre a relação entre sua obra e seu ofício: “A problemática da história das ciências foi objeto de trabalhos e discussões de seminário no Institut d'histoire des Sciences et des Techniques da Universidade de Paris em 1964-1965 e em 1965-1966" 2. Esse esclarecimento apareceu em nota de rodapé ao texto "O objeto da história das ciências", publicado em 1968 como introdução ao livro Estudos de história e de filosofia das ciências, mas originalmente apresentado dois anos antes, como conferência na Universidade de Montreal, onde Canguilhem esteve a convite da Société canadienne d'histoire et de philosophie des sciences. Seguindo os textos publicados nesse período, podemos perceber como a aproximação com a

${ }^{1}$ CANGUILHEM, "Préface", In: DELAPORTE, Le second règne de la nature, p. 8.

${ }^{2}$ CANGUILHEM, "L'objet de l'histoire des sciences", p. 7. 
epistemologia de Bachelard a partir da segunda metade dos anos 50, sem dúvida crucial para a teoria canguilhemiana da história das ciências, marcou uma reformulação daquela problematização, e não o seu abandono.

É lamentável que a maioria das interpretações sobre Bachelard continue a ser produzida a partir de uma leitura interna dos seus textos, que, sem considerar a transformação produzida no campo da história das ciências, contribui para reforçar a suspeita e rejeição dos historiadores pela epistemologia histórica. Bachelard escreveu num momento em que a história das ciências ainda era uma disciplina filosófica, mas no qual os filósofos tentavam expulsar certas filosofias da história do interior da história das ciências. As críticas de Bachelard aos historiadores de oficio devem ser lidas considerando sua época, quando o positivismo ainda ocupava espaços importantes nos tradicionais centros de ensino e pesquisa da França. Daí Bachelard ter dito, em A formação do espírito científico, que os historiadores nada faziam senão coligir documentos, tratando as ideias científicas como um fato qualquer, enquanto os epistemólogos tomavam os fatos de ciência como ideias, que, inseridas num sistema de pensamento, formavam uma história intelectual. Ou ainda, como no artigo "L'actualité de l'histoire des sciences", criticar a escolha das fontes escolhidas pelos historiadores: "A história das ciências não pode ser simplesmente uma história de registros. As atas das academias contêm naturalmente numerosos documentos para a história das ciências. Mas estas atas não constituem verdadeiramente uma história das ciências"3. Foi por reconhecer a originalidade trazida pela obra de Bachelard que Canguilhem saiu em defesa da sua identificação como historiador das ciências: "Em um sentido, Bachelard nunca a fez [história das ciências]. Num outro sentido, ele nunca deixou de fazê-la". Se entendermos história das ciências como o recenseamento das variantes nas diversas edições de um tratado, diz Canguilhem, então Bachelard nunca foi um historiador das ciências. Mas, se a história das ciências consiste em tornar inteligível a edificação difícil, contrariada, retomada e retificada do saber, então, a epistemologia bachelardiana é uma história das ciências sempre em ato ${ }^{4}$.

Em "O objeto da história das ciências", Canguilhem partiu de três questões: queria saber o "Quem?", o "Por quê?" e o "Como?” da história das ciências (fez questão de esclarecer que essa reflexão tem sua origem no seminário apresentado por Jacques Piquemal em um dos seus cursos). A questão “Quem?”, disse, provocava quase imediatamente a questão "Onde?”. Quais os lugares institucionais da história das ciências? De quais departamentos universitários vêm os historiadores das ciências? Muitas vezes, as exigências de ensino e de pesquisa sentidas

\footnotetext{
${ }^{3}$ BACHELARD, "L'actualité de l'histoire des sciences", p. 141-142

4 CANGUILHEM, "L’histoire des sciences dans l'œuvre épistémologique de Gaston Bachelard”, p. 178.
} 
por um determinado setor das ciências no interior de uma instituição universitária favorecem aquilo que Canguilhem chamou de "domiciliação" da história das ciências, quer dizer, o fato de que exista, por exemplo, uma disciplina "História da biologia" no departamento de biologia ou "História da Física" no departamento de física. Canguilhem fala também de uma contradição, apontada por Bernhard Sticker, então diretor do Instituto de História das Ciências de Hamburgo, entre a destinação e o método da história das ciências: sua destinação deveria fazer com que ela fosse ensinada nos departamentos científicos, enquanto seu método a sediaria na faculdade de filosofia. Haveria ainda uma terceira opção: "Se a tomamos como uma espécie em um gênero, a história das ciências deveria ter seu lugar em um instituto central de disciplinas históricas"

Conforme Canguilhem, os interesses específicos dos historiadores e dos cientistas só os conduziam à história das ciências por uma "via lateral". Os cientistas não teriam, para o desempenho de sua prática científica específica, necessidade de conhecer a história das ciências, ainda que não possam dispensar um mínimo de conhecimento histórico e filosófico para a comunicação dos seus trabalhos aos seus interlocutores. Quando os cientistas se tornam historiadores, geralmente é por razões estranhas aos requisitos intrínsecos das suas pesquisas, embora seus campos de pesquisa histórica sejam determinados pelas suas competências específicas em tal ou tal campo científico. E, considerando a historiografia de sua época eminentemente "política e social, completada por uma história das ideias religiosas ou filosóficas", Canguilhem também não chega a ver a história das ciências como uma demanda necessária dos historiadores. Quanto aos filósofos, diz Canguilhem, eles costumam chegar à história das ciências por duas vias: "tradicionalmente e indiretamente" pela história da filosofia, na medida em que tal ou tal filosofia solicitou esclarecimentos a uma ciência triunfante, ou "mais diretamente, através da epistemologia”, quando se quer celebrar o poder de um método científico atual através da gloriosa história da superação dos equívocos pregressos. Se parasse aí, Canguilhem ofereceria uma dificuldade aos seus leitores, pois sabemos que é pela epistemologia que ele chega à história das ciências. Mas o objetivo desse texto sobre o objeto da história das ciências é justamente o de mostrar que "se a filosofia mantém com a história das ciências uma relação mais direta do que aquelas mantidas pela história ou pela ciência, é com a condição de aceitar, em função dessa proximidade, um novo estatuto de sua relação com a ciência"6 ..

Retornaremos a esse novo estatuto entre filosofia e ciência no último capítulo, quando tratarmos da "epistemologia histórica". Mas é interessante, como esclarecimento sobre essa crítica de Canguilhem, mencionar já aqui o artigo "A ideia de epistemologia", no qual Gérard

\footnotetext{
${ }^{5}$ CANGUILHEM, "L'objet de l'histoire des sciences", p. 9.

${ }^{6}$ Ibidem, p. 11.
} 
Lebrun pergunta o que deve significar a palavra ciência para que o gênero epistemologia se torne não apenas aceitável, mas indispensável. "Haverá ao menos um sentido da palavra ciência que impossibilitaria a epistemologia?". 7 A resposta é afirmativa e o exemplo citado é justamente a compreensão de ciência que encontramos entre os pensadores do século XVII. Segundo Lebrun, a filosofia de Descartes, por exemplo, jamais poderia se passar por epistemologia. Pois se Descartes desceu até o domínio particular da Matemática, não foi com o objetivo de responder a pergunta "Por que é assim e como se sabe que é assim?", mas para retirar daí exemplos para o Método. A epistemologia não era possível enquanto não fosse permitido às ciências ter uma história própria, ou seja, enquanto admitia-se que a Razão homogênea, a scientia generalis, produzia todos os critérios de racionalidade dos quais as ciências particulares eram apenas a objetivação. Ainda de acordo com Lebrun, mesmo a Crítica kantiana, já no século XVIII, não pode ser considerada um manual de epistemologia. Quando Kant pergunta "Como é possível a Matemática pura?", na verdade ele quer saber como são possíveis os juízos sintéticos a priori, ou seja, questiona-se sobre o uso teórico da razão em geral e as possibilidades da Metafísica como ciência.

Mas, ainda de acordo com Lebrun, mesmo que a Crítica kantiana não sirva de manual para a disciplina, foi nela que despontou pela primeira vez essa "atitude do epistemólogo", que conduz à heterogeneidade das ciências. ${ }^{8}$ Kant fez com que a própria razão interrogasse as ciências para responder a pergunta que, enfim, resume a primeira Crítica: "O que posso saber?". A tese de que a razão tomaria conhecimento de si e dos seus poderes a partir dos questionamentos que faz às ciências particulares introduz um tema nada óbvio da filosofia kantiana: o de uma história transcendental da razão. Ainda que o próprio Kant tenha habilitado intelectualmente esse tema na primeira Crítica, sobretudo nos dois prefácios e nos dois últimos capítulos, “A

7 LEBRUN, “A ideia de epistemologia", p. 130. Uma nota biográfica de Gérard Lebrun, extraída do seu artigo "De la supériorité du vivant humain dans L'Évolution créatrice", p. 208, ilustra a importância de Canguilhem no ambiente acadêmico francês: "J'ai été conduit à ce theme par le souvenir que je garde de mon tout premier contact avec l'œuvre de Georges Canguilhem, au début des annés 1950. Un livre comme La connaissance de la vie était bien fait pour déconcerter un étudiant de ce temps-là, dont l'intérêt était centré, à peu près forcement, sur la pensée dialectique et la phénoménologie. On était soudain mis en présence d'un auter dont la force et l'originalité philosophique provenaient en grande partie de sa familiarité avec la biologie et l'histoire des sciences. Cette lecture eut nottament l'effet d'éveiller assez vite ma défiance à l'égard de la notion de «biologisme», très en vogue à l'époque et de résonance aussi infame que celle de «psychologisme». Grâce à Georges Canguilhem, on se apercevait qu'une pensée philosophique n'était nullement triviale parce qu'elle partait du principe que la connaissance est un produit ou - quil sait ? - un accident de la vie - et aussi qu'elle ne conduisait nullement de ce fait à une « animalisation » de l'homme. Sans l'autorité de Georges Canguilhem, il m'aurait été personnellement difficile d'aborder sans parti pris des auteurs comme Nietzsche, Schopenhauer, Bergson, que la formation universitaire de l'après-guerre tendait à nous faire considerer, aux mieux, avec condescendence."

8 Ibidem, p. 137. 
arquitetônica da razão pura" e "A história da razão pura”, seus comentadores costumam tratá-lo, no máximo, de sobrevôo e frequentemente o excluem das suas análises por considerarem-no bastante embaraçoso, já que estaria em desacordo com o caráter "puro" da razão. E, no entanto, é essa tese sobre a historicidade da razão que dá fundamento à ruptura bachelardiana em filosofia das ciências, como mostraremos no último capítulo.

De volta ao artigo de Canguilhem, encontramos a ideia de que a pergunta "Por que?", isto é, a questão sobre porque escrever a história das ciências, é simétrica à pergunta sobre o "Quem". Por que escrever a história das ciências em cada um daqueles lugares institucionais? Porque existem três razões: a histórica, a científica e a filosófica. A razão histórica, diz Canguilhem, é extrínseca à ciência, "entendida como discurso verificado sobre um setor delimitado da experiência"9. Ela consiste, basicamente, nas celebrações de descobertas, geralmente para reivindicação de uma linhagem intelectual como argumento para solução de uma querela. "Essa razão é um fato acadêmico", diz Canguilhem, um fato "ligado à existência e à função das Academias e à multiplicidade das academias nacionais”. Por sua vez, os cientistas habituaram-se a começar o anúncio de um resultado teórico ou experimental inovador com algumas páginas de história. Assim, podem estabelecer uma continuidade entre uma ideia desconcertante para seus contemporâneos e o passado, esperando assim poder dizer o que jamais diriam se não contassem com a autoridade dos antigos: "assim Hugo de Vries redescobriu o mendelismo e descobriu Mendel”, disse Canguilhem ${ }^{10}$. Não seria absurdo suspeitar que a nefasta figura do "precursor", tão cara a alguns historiadores, tenha nascido da busca dos cientistas pelos seus predecessores. Por fim, a razão propriamente filosófica - "propriamente" porque Canguilhem fala já considerando o novo estatuto da relação entre filosofia e ciência - consiste no fato de que "sem referência à epistemologia, uma teoria do conhecimento seria uma meditação sobre o vazio e que sem relação com a história das ciências uma epistemologia seria um duplo perfeitamente supérfluo da ciência sobre a qual ela pretende discorrer" ${ }^{11}$.

Para Canguilhem, é a questão “Como fazemos a história das ciências?” que mais se aproxima da pergunta ainda mais fundamental, porém geralmente pouco problematizada, de que trata seu artigo. Cinquenta anos atrás, Canguilhem admirava-se com o fato de que a pergunta " $D e$ que a história das ciências é a história?”, que deveria ser o início de qualquer teoria da História das Ciências, quase nunca era feita pela historiografia, afinal sua resposta é evidenciada já no nome da disciplina. Porém, seu sentido não é unívoco. Pois não basta dizer que as ciências são o objeto da história das ciências, ou então o século XX não teria sido palco de conflitos entre

\footnotetext{
${ }^{9}$ CANGUILHEM, "L'objet de l'histoire des sciences", p. 9.

${ }^{10}$ Idem.

${ }^{11}$ Ibidem, p. 11-12.
} 
programas tão distintos para a disciplina. É esse o pano de fundo da oposição entre as posturas que, no mundo anglo-saxão, foram chamadas de internalista e externalista.

Canguilhem fez uma breve referência, em nota de rodapé, a um debate cujas posturas causaram muita repercussão na França, iniciado quando Henri Guerlac acusou os partidários da história intelectual das ciências de "idealistas", pois ignorariam a íntima relação entre ciência pura e aplicada, desconsiderando, assim, o papel da ciência como fator histórico. Em resposta, Alexandre Koyré afirmou que, ao contrário da vertente externalista, jamais escreveria uma história em que a técnica suplantasse o papel da razão, dando ao homem a função de espectador e transformando os esforços intelectuais em uma "ciência de engenheiro" ou mesmo uma história que substituísse o papel da razão em prol de uma suposta vontade de poder que quer tornar o homem mestre da natureza. Para Koyré, em ambos os casos, trata-se de um desconhecimento da natureza do pensamento científico e um preconceito, pois a interação entre a teoria e a prática é um fenômeno essencialmente moderno. ${ }^{12}$ Assim, para Koyré, a ciência, seja a nossa ou a dos gregos, não poderia ser rastreada a partir dos instrumentos, das técnicas ou a partir do desenvolvimento das nações; ela possui uma história imanente "e é somente em função de sua própria história que ela pode ser compreendida pelos seus historiadores"13.

Para Canguilhem, internalismo e externalismo não são posturas metodológicas a partir das quais a história das ciências deve buscar se orientar, mas equívocos causados por uma má compreensão da natureza do seu objeto. O internalismo, frequentemente acusado de idealismo, consiste, para Canguilhem, em pensar que a história das ciências é encontrada exclusivamente no interior dos livros de ciência e que a tarefa do historiador é buscar nessa obra científica aquilo que permite defini-la como ciência, e não como ideologia ou como técnica. Por outro lado, muito do que os discursos externalistas chamam de ciência, segundo Canguilhem, é assim denominado por uma questão de tradição, pois sem análise crítica, sem um estudo sobre os critérios de racionalidade, não há como saber se tal reivindicação é merecida. Em seguida, os externalistas relacionam essas supostas ciências com questões ideológicas, com exigências práticas ou técnicas, de ordem econômica ou política. O externalismo é, para dizer brevemente, um "marxismo empobrecido típico de sociedade rica" 14 . Ao sintetizar as diferenças entre uma

\footnotetext{
${ }^{12}$ Cf. KOYRÉ, Perspectives sur l'histoire des sciences, p. 398: “Aussi surprenant que cela puisse nos paraitre, on peut édifier des temples et des palais, et même des cathédrales, creuser des canaux et bâtir des ponts, développer la métallurgie et la céramique, sans posséder de savoir scientifique; ou en n'en possedents que des rudiments. La science n'est pas nécessaire à la vie d'une société, au développment d'une culture, à l'édification d'un État et même d'un Empire".

${ }^{13}$ Ibidem, p. 399.

${ }^{14}$ Cf. CANGUILHEM, "L'objet d'histoire des sciences", p. 15: “C'est, en somme, un marxisme affaibli ou plutôt appauvri, ayant cours dans les sociétes riches". Michael Polanyi (POLANYI, Science, faith and society, p. 07) explica como se deu esse empobrecimento: "In August 1938 the British Association for the
} 
postura e outra, Canguilhem encontra também aquilo que faz do externalismo e do internalismo as duas faces de uma mesma moeda:

É evidente que uma e outra posição consistem em assimilar o objeto da história das ciências ao objeto de uma ciência. O externalista vê a história das ciências como uma explicação de um fenômeno cultural através do condicionamento do meio cultural global, e assimila-a, por conseguinte, a uma sociologia naturalista das instituições, desprezando completamente a interpretação de um discurso com pretensão de verdade. O internalista vê nos fatos da história das ciências, por exemplo os casos da descoberta simultânea (cálculo infinitesimal, conservação da energia), fatos dos quais não se pode fazer história sem teoria. Aqui, por conseguinte, o fato da história das ciências é tratado como um fato da ciência, a partir de uma posição epistemológica que consiste em privilegiar a teoria relativamente ao dado empírico. ${ }^{15}$

Isso explica porque o debate foi deixado de lado, sem que um vencedor houvesse sido decretado. Afinal, por mais estranhas que as posições idealistas e externalistas possam parecer uma à outra, Canguilhem identificou nelas um erro comum: uma "atitude espontânea", quer dizer, irrefletida, "que consiste em alinhar a história sobre a ciência, quando se trata da relação do conhecimento com seu objeto"16. Falando especificamente sobre o "onde?" deste trabalho, não é incomum encontrarmos historiadores que, tendo se desfeito daquela ideia de ciência como discurso verificado sobre um setor delimitado da experiência, fizeram da história das ciências a história da produção de um consenso cognitivo determinado institucionalmente ou politicamente. Pode-se reconhecer aí a nobre intenção de livrar a história das ciências desse estigma de provincial branch, termo utilizado por Momigliano para descrever a situação de nãopertencimento da História Antiga em relação ao campo histórico na primeira metade do século passado.

Mas tal postura, radical sob muitos aspectos, não difere do internalismo e do externalismo no que diz respeito ao nosso problema específico. Recusando a crítica epistemológica, isso é, a possibilidade de uma abordagem racionalista do discurso científico, essa historiografia se recusa a ver o que há de especificamente científico nas controvérsias, fazendo da ciência um fenômeno inteiramente condicionado por um meio social global, legível nas

Advencement of Science founded the Division for the Social and International Relations of Science, which was to give social guidance to the progress of science. A movement for the planning of science spread and became predominant among scientists interested in public affairs. A small number of scientists, to wich I belonged, strenuously opposed this movement. (...) Since then the planning movement has dwindled to insignificance in Britain, but the theoretical problems it has raised are still with us. They are part of the general impact made by the Russian Revolution on the minds of men everywhere."

${ }^{15}$ CANGUILHEM, "L'objet d'histoire des sciences", p. 15.

${ }^{16}$ Ibidem, p. 15-16. 
controvérsias acadêmicas e institucionais dos cientistas. Ela mantém e reforça a assimilação do objeto da história das ciências ao objeto de uma ciência, ainda que se trate de outra ideia de ciência. Canguilhem, por sua vez, propôs uma mudança na relação que os historiadores das ciências mantêm com o seu objeto, esperando assim poder contribuir para a historicização das ciências:

O objeto do discurso histórico é, de fato, a historicidade do discurso científico, na medida em que essa historicidade representa a efetuação de um projeto interiormente normatizado, mas atravessado por acidentes, retardado ou desviado por obstáculos, interrompido por crises, quer dizer, por momentos de julgamento e de verdade. ${ }^{17}$

Comentando o famoso trabalho de Hélène Metzger sobre a gênese da ciência dos cristais, Canguilhem afirma que sua autora elaborou um discurso sobre os discursos sobre os cristais. Se, em La Genèse de la Science des cristaux, Metzger pôde dizer que a "cristalografia se constitui a partir do momento em que se definiu a espécie cristalina pela constância do ângulo das faces" foi porque ela fez do objeto da história das ciências a história dos discursos metódicos que pretenderam transformar um objeto natural, os cristais, em objeto científico. E como esses objetos naturais são, nas palavras de Canguilhem, “objetos de uma experiência usual e de percepção em uma cultura", os discursos sobre esse objeto natural, a decisão de transformá-los em objetos científicos e os meios teóricos elaborados para fazê-lo, serão necessariamente objetos culturais. Assim, o objeto da história das ciências - a historicidade do discurso científico - seria segundo, embora não derivado, em relação ao objeto das ciências. Mas qual a matéria-prima desse tipo de história? A partir de quais elementos o historiador deve se informar sobre as perguntas constituídas no interior da sua disciplina? Nesse ponto, Canguilhem certamente concorda com Bachelard: "para dizer tudo o que penso, creio que a história das ciências não pode ser uma história empírica"18. Vejamos suas palavras, ainda na introdução aos Estudos:

A história das ciências pode, sem dúvida, distinguir e admitir vários níveis de objetos no domínio teórico específico que ela constitui: documentos para catalogar; instrumentos e técnicas para descrever; métodos e questões para interpretar; conceitos e questões para analisar e criticar. Só esta última tarefa confere às antecedentes a dignidade de história das ciências. Ironizar acerca da importância dada aos conceitos é mais fácil do que compreender porque é que sem eles não há ciência. A história dos instrumentos ou das academias não é história das ciências a não ser que eles sejam postos em relação, nos seus usos e

\footnotetext{
${ }^{17}$ CANGUILHEM, "L'objet d'histoire des sciences", p. 18-19.

${ }^{18}$ BACHELARD, L'actualité de l'histoire des sciences, p. 151.
} 
nos seus destinos, com teorias. ${ }^{19}$

Essa história das academias é, para Canguilhem, a história dos descobridores e das descobertas. E ela é também a história dos instrumentos, não apenas por uma predominância do interesse pela técnica, mas porque, sem uma compreensão fenomenotécnica, ela pode se transvestir em "história dos fenômenos", uma história da observação dos cientistas. O problema, para Canguilhem, é que os historiadores nem sempre tomam o cuidado de levar em conta o espaço que essa observação ocupa no interior de uma explicação científica. É bastante comum nesse tipo de história que se atribuam certas explicações recorrentes sem relação com as possibilidades discursivas da época estudada. É o caso da afirmação de que Priestley é o verdadeiro descobridor do oxigênio por ter sido o primeiro a produzi-lo em laboratório, embora o interpretasse erroneamente como ar desflogisticado, em vez de Lavoisier, que efetivamente compreendeu o oxigênio como um elemento químico. Para Canguilhem, se a história das ciências foi frequentemente escrita como uma "história natural", é porque os historiadores identificavam a ciência com os cientistas, os cientistas com sua vida acadêmica, a ciência com os seus resultados e os resultados com seu enunciado pedagógico atual.

Podemos recorrer a uma controvérsia bem conhecida pela historiografia brasileira para mostrar como a história dos conceitos, tal como proposta por Canguilhem, se delimita dessa história das observações e da sua função ideológica de celebração dos grandes heróis das ciências. Mais especificamente, recorrer à controvérsia historiográfica sobre a controvérsia científica em torno da doença de Chagas, isto é, o debate sobre o significado historiográfico das disputas acerca do enquadramento clínico da doença e a formação do conceito de tripanossomíase americana. Essa controvérsia historiográfica tem início em 1993, quando François Delaporte, então professor na Université Picardie-Jules Verne, apresentou uma conferência na Fundação Oswaldo Cruz, dando notícias de suas pesquisas sobre a doença de Chagas. Publicado em 1995 na revista Manguinhos, o texto da conferência apresenta o seguinte resumo:

Esse artigo examina como acaso e erro estavam na raiz da descoberta por Carlos Chagas da nova entidade nosológica [disease entity] que subsequentemente recebeu o seu nome. Da perspectiva da epistemologia histórica, o autor revisa o caminho tomado pela pesquisa de Chagas e levanta dúvidas sobre o que se tornou a versão oficial, concluindo que a lógica da história contradiz o direito da lógica. $^{20}$

\footnotetext{
${ }^{19}$ CANGUILHEM, "L'objet de l'histoire des sciences", p. 19.

${ }^{20}$ DELAPORTE, "Chagas, a lógica e a descoberta". Manguinhos, Rio de Janeiro, vol.1, n.2, p. 39-53. 1995. grifo nosso.
} 
Formado na Sorbonne nos anos 60, mais tarde mestrado e doutorado em história das ciências na mesma instituição, Delaporte foi aluno e discípulo de Foucault e de Canguilhem. Ao dizer que abordará o tema da doença de Chagas a partir da "perspectiva da epistemologia histórica" e ao concluir que, no caso da doença de Chagas, "a lógica da história contradiz o direito da lógica", Delaporte fazia referência direta àquela lição de Canguilhem (registrada na sua tese de doutorado em filosofia sobre a formação do conceito de reflexo) a propósito da história das filiações conceituais: "Pessoalmente, acreditamos que em matéria de história das ciências os direitos da lógica não devem se apagar diante dos direitos da lógica da história." ${ }^{21}$

Para Delaporte, a "historiografia oficial" da doença de Chagas teria feito parecer que as infecções experimentais, o estudo do ciclo genético do parasito, a observação clínica e a descoberta de uma nova entidade mórbida decorressem da observação no microscópio dos flagelados no intestino do inseto. Essa reconstituição, "historicamente falsa", diz Delaporte, encontrava suporte num suposto dogma da medicina tropical: a sequência "um parasito, um vetor, uma doença". Apoiado em ampla fonte documental, Delaporte argumenta que as pesquisas iniciais de Chagas sobre o tripanossomo demonstravam um interesse de parasitologista, não de patologista. Chagas acreditava ter encontrado um parasito não patogênico do macaco; o dogma ao qual estava inicialmente submetida a sua pesquisa não era aquele da medicina tropical, mas o da história natural: um parasito (as formas critidiais que Chagas acreditava serem de Trypanosoma minasense), um vetor (o barbeiro, em cujo intestino Chagas encontrou as critídias) e um hospedeiro (o macaco). As infecções experimentais feitas por Oswaldo Cruz no Rio de Janeiro mostrariam o erro de Chagas quanto à classificação inicial do tripanossomo, mas incitariam à busca por um hospedeiro diferente do macaco. Ao enfatizar as observações experimentais e a descoberta de um novo parasito, em vez de centrar a questão sobre as hipóteses que conduziram Chagas ao erro - erro positivo, registre-se -, a historiografia tradicional, segundo Delaporte, fazia com que o gênio de Chagas já soubesse exatamente onde chegaria: "Graças ao poder da lógica apoiada na experiência, o tempo iria rapidamente colocar no fim do percurso o que estava contido no início". 22

Em seu livro Doença de Chagas, doença do Brasil: ciência, saúde e nação (1909 - 1962) Simone Kropf concorda que, desde o início, Chagas descreveu os distúrbios endócrinos, neurológicos e cardíacos como as principais manifestações clínicas da doença, com ênfase nos primeiros, especialmente os distúrbios tireoidianos. Por isso, o bócio foi considerado o sinal primordial para o diagnóstico clínico da doença de Chagas, nomeada "tireoidite parasitária", e

\footnotetext{
${ }^{21}$ CANGUILHEM, "La formation du concept de réflexe", p. 5.

${ }^{22}$ DELAPORTE, "Chagas, a lógica e a descoberta”, p. 39.
} 
para seu enquadramento como entidade nosológica específica. Para Kropf, o ano de 1916 seria determinante na história da doença, pois sua caracterização clínica e epidemiológica se tornou objeto de uma controvérsia científica em função de estudos realizados na Argentina pelo microbiologista austríaco Rudolf Kraus, que questionou a etiologia parasitária do bócio endêmico. "Apesar da presença de barbeiros infectados e de 'papudos' no território argentino, os pesquisadores inquietavam-se com o fato de não haver sido diagnosticado nenhum caso humano da doença no país" ${ }^{, 23}$. Kraus argumentava que as manifestações tireoidianas e neurológicas eram manifestações de outras doenças, o bócio e o cretinismo endêmico, sobrepostas à doença de Chagas. Diante das críticas, Chagas, que interpretava o debate como uma controvérsia científica, “deu início a um importante processo de 'reenquadramento' no desenho clínico da tripanossomíase, minimizando a primazia dos sinais tireoidianos e reforçando a importância dos elementos cardíacos." 24 .

Porém, a doença de Chagas, argumenta Kropf, nunca foi um objeto de interesse puramente científico. Para a autora, desde os primeiros textos de Chagas, ela começou a se constituir como objeto ao mesmo tempo médico e social, como uma doença inimiga do progresso e da modernidade. A identificação do bócio como principal sinal clínico da doença fez com que as autoridades estimassem um número exagerado de doentes no interior do país, o que motivou disputas políticas sobre campanhas de saneamento rural. Fixavam-se duas imagens: a de Chagas como o Pasteur brasileiro, e a do Brasil como um imenso hospital. As pesquisas de Kraus, ao questionar a relação entre o bócio e a tireoidite parasitária, atingiam a glória da ciência brasileira, ao mesmo tempo em que retiravam a evidência das previsões de milhões de brasileiros doentes. A entidade nosológica estava na berlinda, dizia a imprensa popular da época, que acompanhava com atenção os debates travados na Academia Nacional de Medicina, que persistiram mesmo após a morte de Chagas e conduziram ao novo enquadramento da doença como mal cardíaco crônico. Novamente da Argentina veio outra contribuição à história da doença: em 1935, Cecílio Romaña descreveu a conjuntivite esquizotripanósica unilateral, o "sinal de Romaña", como sinal clínico distintivo da doença. Esse é o acontecimento decisivo para que Delaporte rejeitasse qualquer possibilidade de continuidade na história que vai da observação por Chagas das formas critidiais no intestino do barbeiro até o sinal de Romaña e a formulação do conceito de tripanossomíase americana:

(...) a formulação do conceito de tireoidite parasitária constituiu o maior obstáculo à elucidação da natureza da tripanossomíase americana. A percepção de Chagas pesou de

\footnotetext{
${ }^{23}$ KROPF, "Carlos Chagas e os debates e controvérsias sobre a doença do Brasil (1909 - 1923)", p. 212.

${ }^{24}$ Ibidem, p. 213.
} 
forma considerável na história das pesquisas sobre essa nova doença. (...) Um tempo de latência separa a constituição do sistema médico de Chagas da reestruturação epistemológica que torna possível a formação do conceito de tripanossomíase americana. Não há nenhum paradoxo na ideia de que o ponto forte do sistema de Chagas se revelará, na sequência, o elo mais fraco. ${ }^{25}$

Delaporte evidentemente não ignora aquelas controvérsias políticas sobre a entidade nosológica. Mas, através delas, o que buscava encontrar era a história da edificação do conceito de tripanossomíase americana. No prefácio que escreveu a Histoire de la fièvre jaune, Canguilhem diz que "Delaporte pertence a essa variedade de historiadores das ciências que não tem por profissão denegrir a epistemologia". Poderíamos dizer da investigação sobre a doença de Chagas aquilo que Canguilhem falou sobre a história que Delaporte escreveu da febre amarela:

A história dessa elucidação conceitual, cujas consequências práticas em matéria de tratamento e de prevenção constituem a prova da validade, é também a história de um certo número de personagens, de atores, implicados por suas funções, seus trabalhos, suas responsabilidades, numa história propriamente política (...). Ele [Delaporte] soube não confundir um precursor e um fundador, uma palavra e um conceito (...). Ele soube descobrir, nessa laboriosa e às vezes mesquinha controvérsia, uma aquisição importante para a biologia.

No entanto, assim como no exemplo dos cristais, que nos convida a considerar a apreciação que determinada cultura faz de um objeto natural, problemas como a doença de Chagas, que nunca se reduziu à entidade nosológica "puramente" natural, mas sempre foi tratada como uma questão ao mesmo tempo médica e civilizatória, permitem uma reflexão sobre a natureza do objeto da história das ciências. Canguilhem cita o exemplo da história da introdução e da extensão das matemáticas probabilísticas na biologia e nas ciências do homem no século XIX. Conforme Canguilhem, o objeto dessa história não corresponde a nenhum objeto natural, e o historiador também não pode localizar sua pré-história em qualquer outra ciência constituída. Pelo contrário, a biometria e a psicometria, segundo Canguilhem, só puderam ser constituídas quando práticas não-científicas forneceram à observação uma matéria passível de tratamento matemático: o estudo de Quêtelet sobre a altura humana supõe a instituição dos exércitos nacionais e dos critérios físicos para alistamento; o estudo de Binet sobre as aptidões intelectuais pressupõe a instituição da escolaridade primária e o interesse pelas razões do atraso intelectual. Daí a seguinte conclusão:

Assim, a história das ciências, na medida em que ela se aplica ao objeto acima delimitado, não diz respeito apenas a um grupo de ciências sem coesão

\footnotetext{
${ }^{25}$ DELAPORTE, $A$ doença de Chagas: história de uma calamidade continental, p. 72.
} 
intrínseca, mas também à não-ciência, à ideologia, à prática política e social. Assim, esse objeto não encontra seu lugar teórico natural em tal ou tal ciência de onde a história iria pegá-lo, mas isso também não quer dizer que seu lugar seria na política ou na pedagogia. O lugar teórico desse objeto não pode ser buscado senão na própria história das ciências, pois é ela, e apenas ela, que constitui o domínio específico onde encontram seu lugar as questões teóricas postas pela prática científica em seu desenvolvimento. ${ }^{26}$

\section{O estatuto social da ciência}

É interessante notar a progressão dos cursos de Canguilhem. Durante os primeiros cinco anos, Canguilhem dedicou-se a temas mais clássicos da história e da filosofia das ciências, como a visão como modelo de conhecimento (no curso 1956-57); o singular e a singularidade (195758); a filosofia de Auguste Comte (1958-59); a obra científica de Descartes e a ciência do século XVII (1959-60) e a finalidade biológica na Crítica kantiana (1960). Em seguida, notamos uma mudança na orientação do ensino de Canguilhem que passa a se interessar por temas que problematizam a relação entre ciência e não-ciência e entre as ciências e as técnicas, como o estatuto social da ciência moderna (1961-62); normal e patológico, norma e normal (1962-63) e a filosofia da ação (1966-67). Por fim, a partir de 1967, até a sua aposentadoria da Sorbonne, os quatro cursos ministrados sob a rubrica geral "Histoire des théories et des idéologies scientifiques modernes et contemporaines", dedicados aos seguintes temas: Ciência e ideologia na constituição da psicologia (1967-68); o evolucionismo (1968-69); a ideologia médica no século XIX (196970) e a ideologia médica no século XIX: neurologia e psiquiatria (1970-71).

Transcrevemos aqui a argumentação inicial do curso de 1961-62, dedicado ao estatuto social da ciência:

Revue de 1'Eseignement Supérieur - "Nécesssité de la 'diffusion scientifique", verão 1961.

Situação da ciência na sociedade moderna. Aquilo que, precisamente, entendemos por isso e aquilo a que nos propomos:

Por ciência moderna entendemos a ciência desde o começo do século XVII: essa atividade da qual Galileu, Harvey e Descartes fixam tanto o sentido quanto os meios.

Entendemos por estatuto social o conjunto historicamente em transformação entre a ciência, como produto específico dos cientistas [savants], e a "sociedade" (no sentido colegial, nacional, cosmopolita), quer se trate de estatuto no sentido

\footnotetext{
${ }^{26}$ CANGUILHEM, "L'objet d'histoire des sciences", p. 18-19.
} 
estreito e jurídico do termo - como, por exemplo, a organização das Academias ou das Universidades -, quer se trate de situações de fato, por exemplo, do lugar e da posição que a opinião pública, em uma sociedade industrial hoje, atribui a um físico nuclear.

Definindo a ciência como produto específico das ocupações dos cientistas, por um lado nos afastamos por provisão - mas não eliminamos, longe disso - uma reflexão sobre as condições transcendentais da possibilidade da ciência. Por cientista nós entendemos, sem dúvida, também uma consciência de intenção teórica, mas entendemos primeiramente e acima de tudo um homem que tem um lugar de nascimento, que fala uma língua nacional, que é o contemporâneo - e não apenas o espectador - de uma história que não se reduz à história das ciências. É o homem pelo qual a ciência, atividade estritamente teórica, tem uma história e não apenas um destino ou uma lógica.

É preciso, então, eliminar diversas confusões possíveis.

Não se trata de sociologia do conhecimento - nem no sentido de Durkheim (conclusão de Formes El. De la Vie Religieuse), quer dizer, uma derivação das categorias do pensamento a partir das estruturas da sociedade ou da experiência que tem o indivíduo de seu grupo social - nem no sentido dos sociólogos do saber de filiação ou de inspiração marxista: não pretendemos investigar se a ciência, como sistema de ideias concernentes ao real, entra ou não na esfera das ideologias cuja realidade social - identificada com suas estruturas - explica não apenas a aparição e a difusão mas o conteúdo conceitual.

Mas uma coisa é recusar uma explicação sociológica do conteúdo do saber, na medida em que esse saber engloba essencialmente uma afirmação de realidade em sua relação com o objeto do qual ele se diz o saber, e outra coisa é se recusar a perceber que a ciência, na medida em que ela tem uma história, "onde Hiparco não descobriu as leis de Kepler", mantém uma relação obrigatória com a "situação" social (situação no sentido existencial, não no sentido econômico) dos cientistas.

(...)

O sujeito do conhecimento é a "cidade científica": não retornamos às representações coletivas nem às infra-estruturais. A cidade científica é a reciprocidade pedagógica daquele que ensina e daquele que é ensinado, é uma comunidade de trabalho onde o anonimato é a recompensa do gênio (aquilo que todo mundo deve pensar). Nesse nível epistemológico, o objeto científico não é uma "representação coletiva", mas uma "racionalização coletiva". Diz Bachelard: "Apenas a sociedade pode lançar a eletricidade em um fio". ${ }^{27}$

Canguilhem desenvolve sua reflexão a partir de um conceito tardio de Bachelard, o de "cidade científica". Ele expressa um interesse inédito dos filósofos franceses, em oposição à filosofia idealista, pela prática científica e pelas condições de tal prática. Bachelard explica que a ciência contemporânea não permite mais a ideia do cientista isolado, trabalhando sozinho em seu laboratório. Para ele, o conhecimento científico só pode ser produzido e apreendido no interior da “cidade científica", o que exige até mesmo a criação de uma nova linguagem: "para ser entendido

\footnotetext{
${ }^{27}$ CANGUILHEM, Le statut social de la Science, manuscrito, ff. 3.
} 
na cidade científica, é preciso falar cientificamente a linguagem científica, traduzindo os termos comuns em linguagem científica" 28 . Outro exemplo desse estatuto social da ciência é dado por Canguilhem a partir do uso dos instrumentos. Ele lembra que, em La théorie physique, Pierre Duhem argumentou que o uso de um instrumento científico não é jamais um uso neutro, que ele pressupõe a adesão a uma teoria. Mas Canguilhem reprova Duhem por não ter sequer cogitado a possibilidade de que um instrumento não implica apenas a adesão a uma teoria, mas também "a adesão a uma sociedade, às suas técnicas, à sua economia"29. Canguilhem vê uma continuidade entre a concepção positivista de Duhem sobre o microscópio - que implica uma adesão à teoria óptica, mas para ver um objeto natural, que existe sem a sociedade - e a concepção positivista da história das ciências proposta por Pierre Laffite, discípulo de Auguste Comte, para quem o papel da História das Ciências seria o de um "microscópio mental", imagem que, para Canguilhem, como dissemos, exibe a nu o "pressuposto positivista de que a história é apenas uma injeção de duração na exposição dos resultados científicos. O microscópio procura o crescimento de um desenvolvimento dado sem ele, ainda que visível apenas por ele" ${ }^{\text {30 }}$.

Para Canguilhem, a análise de Bachelard é muito mais profunda que a de Duhem. Bachelard, um "racionalista intransigente e não positivista", diz Canguilhem, também defendia que um instrumento é uma teoria incorporada: “o microscópio não é o prolongamento do olho, mas da inteligência"31. Mas, ele continua, Bachelard também sabia que a ciência moderna é uma fenomenotécnica, isto é, que ela só descreve depois de ter produzido e legitimado o objeto da descrição. Em L'épistémologie historique de Gaston Bachelard, dissertação de mestrado de Dominique Lecourt, escrita sob a orientação de Canguilhem, encontramos uma boa explicação sobre essa ideia de que "a produção dos conceitos científicos não se faz no espaço por espíritos etéreos", mas que ela "se materializa sob a forma de instituições, de encontros, de colóquios..."32, enfim, nos espaços sociais da cidade científica. Ora, historicizar de tal maneira a verdade, fazer dela uma construção social, não significa, em Bachelard, relativizar seu valor de verdade. Lecourt nos lembra que Bachelard insiste sobre a necessidade de medir a coesão e a eficácia dessa cidade científica. Sua coesão permite eliminar “toda aberração derivada do caráter subjetivo de tal ou tal investigador", enquanto sua eficácia viria da "pedagogia recíproca" entre os membros da cidade científica, isto é, circulação das teorias que facilita a aceleração das descobertas - razão pela qual o século XX testemunhou a explosão de "ideias, das quais uma única bastaria para tornar célebre

\footnotetext{
${ }^{28}$ BACHELARD, Le matérialisme rationnel, p. 253,

${ }^{29}$ CANGUILHEM, Le statut social de la Science, manuscrito, ff. 13.

${ }^{30}$ CANGUILHEM, "L'objet de l'histoire des sciences", p. 12-13

${ }^{31}$ CANGUILHEM, Le statut social de la Science, manuscrito, ff. 13.

${ }^{32}$ LECOURT, L'épistémologie historique de Gaston Bachelard, 76.
} 
um século, aparecerem em apenas vinte e cinco anos"33 (para Bachelard, o ano de 1905, ano da Relatividade de Einstein, marca o início da era do novo espírito científico). Conclusão de Lecourt: "a cidade científica é criadora de suas próprias normas. É ela que é detentora dos critérios de objetividade ou de verdade" ${ }^{34}$.

Canguilhem citou o seguinte trecho de Le matérialisme rationnel para falar desse aspecto do estatuto social da ciência moderna:

Se tomamos o conhecimento científico em seu aspecto moderno, compreendendo da melhor maneira possível sua atualidade, não podemos deixar de considerar o valor do seu caráter social bem definido. Juntos, os cientistas se unem em uma célula da cidade científica, não apenas para compreender, mas também para se diversificar, para ativar todas as dialéticas que vão dos problemas precisos às soluções originais. A própria diversificação, já que deve provar socialmente sua validade, não é totalmente individualista. Essa socialização intensa, claramente coerente, segura de suas bases, ardentes em suas diferenciações, eis aí um fato, um fato de uma singular atualidade. Não levar isso em consideração é se especializar em uma utopia gnoseológica, a utopia do individualismo do saber.

E é preciso perceber imediatamente esse caráter social, pois o pensamento essencialmente progressivo da ciência da matéria parte daí em clara ruptura com todo materialismo "natural". O ponto de partida cultural da ciência antecede doravante todo ponto de partida natural. Ser um químico, é se colocar em situação cultural, tomando lugar, alinhando-se, em uma cidade científica claramente determinada pela modernidade da pesquisa. Todo individualismo seria um anacronismo. ${ }^{35}$

Em 1961, o curso de Canguilhem sobre o estatuto social da ciência começou com uma referência a um artigo que ele havia publicado, naquele mesmo ano, na Revue de l'enseignement supérieur, sobre a necessidade da difusão científica. Para Canguilhem, esse é um fenômeno tipicamente moderno - "a ciência desde o começo do século XVII: essa atividade da qual Galileu, Harvey e Descartes fixam tanto o sentido quanto os meios ”, ou, se quisermos uma data mais específica, a ciência a partir de 1699, quando da elaboração de um regulamento para a Académie des Sciences de Paris (fundada em 1666), que "codificou explicitamente a relação entre as ciências e sua utilidade para o Estado" ${ }^{36}$. De acordo com o manuscrito do curso de 1961, a partir dessa data "começa realmente para a ciência seu estatuto social":

1) A Academia é organizada com um centro nacional de investigação. Ela não tem como finalidade o ensino, mas a invenção e o controle da invenção.

\footnotetext{
${ }^{33}$ BACHELARD, A formação do espirito científico, p. 9.

${ }^{34}$ LECOURT, Op. cit., p. 76.

${ }^{35}$ BACHELARD, Le matérialisme rationnel, p. 8-9.

${ }^{36}$ CANGUILHEM, Le statut social de la Science, manuscrito, ff. 18.
} 
2) O cientista ainda não é um funcionário, mas ele já não é mais um amador livre. A proteção real e a pensão real não são mais um Mecenato.

Um Mecenas não exige nada, não regulamenta a concessão de suas liberalidades, ele aguarda e ele recebe.

Podemos destacar que pensão [pension] e pensamento [pensée] tem a mesma origem (Pendere: pesar, pagar). O regulamento de 1699 funda um Cogito da compensação: "Eu penso, logo recebo pensão" [Je pense, donc je suis pensioné].

3) Esse estatuto social da pesquisa científica determina de alguma maneira seu objeto: ele é duplo: o útil ou o curioso.

$\mathrm{E}$ podemos destacar que o útil vem à frente, que as Matemáticas são imediatamente seguidas pelas Artes, que a História Natural e a Física vêm em último lugar. $^{37}$

Canguilhem explica que uma das principais aplicações dessa nova lógica de relações entre ciência e Estado é a fundação dos Observatórios: o de Paris em 1667, o de Greenwitch, na Inglaterra, em 1675. A Royal Society, diz Canguilhem, estimando que "a navegação é assunto de Estado, estimulou a fundação de uma instituição de Estado". Nesse ponto, para Canguilhem, a difusão do conhecimento deixa de ser apenas um assunto intramuros para se transformar numa parte fundamental da materialização do estatuto social das ciências, pois "é preciso que uma informação científica seja transmitida aos artesãos, aos construtores de aparelhos. A correspondência entre Descartes e Ferrier, a propósito do tamanho das lentes ópticas, é um exemplo", escreveu Canguilhem no artigo sobre a difusão científica. "A colaboração dos relojoeiros com os mecânicos, no século XVII, é outro exemplo. Em um sentido, a ciência depende da precisão dos instrumentos, em outro sentido, ela permite essa precisão." 38

O ideal da propagação do saber, típico do Iluminismo do século XVIII, não pode ser dissociado, para Canguilhem, do estatuto social que as ciências adquiriram no século anterior. A diferença é que, no século XVII, a questão da difusão nasceu como assunto de Estado, que não queria ver suas conquistas científicas, materializadas em mapas de navegação e instrumentos de orientação marítima, nas mãos de outro Estado. Para Canguilhem, portanto, a difusão científica não é um fenômeno recente, mas apenas intensificado no século $\mathrm{XX}$, tal foi o crescimento do papel que a ciência adquiriu como "instrumento da rivalidade política entre Estados ou entre coalizões ideológicas" ${ }^{39}$. Mas, no século XX, cabe aos cientistas, diz Canguilhem, decidir "se a comunicação de um resultado de pesquisas à cidade científica, que não conhece as fronteiras da cidade política, é um imperativo categórico ou hipotético". Nessa situação, ele diz, é logicamente impossível que um cientista guarde uma descoberta em segredo, "pois uma descoberta só merece esse nome quando é desligada da pessoa que é responsável por ela (...). Uma descoberta clama

\footnotetext{
${ }^{37}$ CANGUILHEM, Le statut social de la Science, manuscrito, ff. 14.

${ }^{38}$ Ibidem, ff. 7.

${ }^{39}$ Ibidem, ff. 23.
} 
pela contra-prova". 40

\section{As ideologias cientificas}

Esse curso de 1961 sobre o estatuto social da ciência marca tanto uma inflexão no pensamento de Canguilhem quanto o início da aproximação teórica entre as preocupações do marxismo e da história das ciências na França. Não porque Canguilhem tenha aderido ao marxismo, mas porque nessa turma da Sorbonne destacavam-se alguns discípulos de Althusser, como Pierre Macherey e Étienne Balibar. O trecho da aula inaugural que citamos há poucas páginas foi extraído de uma versão datilografada do curso estabelecida pelos alunos de Althusser, e enviada a Canguilhem por Balibar. Na mensagem que acompanhava as páginas datilografadas, Balibar informava a Canguilhem que outras cópias se encontravam em poder de Althusser, de Macherey e do próprio Balibar, e que esse curso era frequentemente relido por eles, sobretudo como fonte de inspiração para o "Curso de filosofia para cientistas", organizado por Althusser na École Normale Supérieure. Esse curso, que teve início em outubro de 1967 e se desenrolou até as vésperas do Maio de 1968, tinha como temas, segundo o próprio Althusser, "os problemas da história das ciências e os conflitos filosóficos que ela cria", "a luta ideológica e as formas que ela pode assumir entre os intelectuais da prática científica"41. A parte inicial do curso, ministrada por Althusser, teve como tema "Filosofia e Filosofia Espontânea dos Cientistas". Em seguida, Macherey e Balibar trataram do tema "Experiência e Experimentação"; Michel Fichant e Michel Pêcheux abordaram, respectivamente, os temas "Ideologia e História das Ciências" e "A ideia de uma história das ciências"; por fim, Alain Badiou apresentou uma abordagem materialista para "o conceito de Modelo". De todas essas aulas, apenas as de Macherey e Balibar não integraram a série "Cours de Philosophie pour Scientifiques", organizada por Althusser na coleção "Théorie" da editora François Maspero.

Como vimos no primeiro capítulo, a proximidade com Althusser, que, num primeiro momento, garantiu um público maior para Canguilhem, também fez com que sua obra fosse deixada de lado num segundo momento, pois ele havia sido confundido com mais um dos althusserianos. Por mais que se critique o peso que a leitura althusseriana jogou sobre a interpretação da obra de Canguilhem, não podemos deixar de reconhecer que, em 1964, naquela apresentação ao texto de Macherey, Althusser já havia detectado uma das principais

\footnotetext{
${ }^{40}$ CANGUILHEM, "Nécesssité de la 'diffusion scientifique"', p. 14-15.

${ }^{41}$ ALTHUSSER, Philosophie et philosophie spontanée des savants, p.7.
} 
características do projeto canguilhemiano para as ciências, o fato de que "toda a complexa realidade da história, em todas as suas determinações - econômicas, sociais, ideológicas -, entra em jogo na inteligência da própria história científica". A história das ciências tal como escreveu Canguilhem se interessará pelas "questões que jamais terão respostas, posto que são questões imaginárias, que não correspondem a problemas reais" (mas podem inaugurar uma tendência); pelas "respostas imaginárias, que deixam sem verdadeira resposta o problema real a que elas aludem"; pelas "ciências que se dizem ciências, mas que não passam de imposturas científicas de uma ideologia social"; pelas "ideologias não-científicas que, através de encontros paradoxais, fazem nascer verdadeiras descobertas - como vemos o fogo surgir do choque de dois corpos estranhos".

A expressão "ideologia não-científica" empregada por Althusser não deve ser menosprezada. "A noção de ideologia científica me veio a partir de Althusser. Não há dúvida quanto a isso", explicou Canguilhem, em entrevista a Jean-François Braunstein e François Bing. ${ }^{42}$ No entanto, se Canguilhem formulou o conceito de ideologia científica para tentar libertar o racionalismo do idealismo, Althusser pretendeu, com a formulação do conceito de "corte epistemológico", que descreve o "salto" entre ciência e ideologia, levar o racionalismo para os domínios do materialismo. Em Althusser, "ideologia não-científica" não implica o reconhecimento da existência, sequer da possibilidade teórica de existência, de uma "ideologia científica". Ideologia não-científica é uma expressão redundante, empregada por Althusser, inicialmente, para se referir ao idealismo histórico das filosofias da história. Em termos althusserianos, uma "ideologia científica" seria - palavras de Canguilhem - um "monstro lógico". O "corte epistemológico" não leva Althusser mais distante no caminho batido por Canguilhem: ele marca, antes, uma bifurcação na investigação sobre as relações entre ciência e não-ciência.

E o que é uma ideologia científica? Questão posta pela prática da história das ciências, e cuja solução é um elemento fundamental para elaboração de uma teoria da história das ciências, afirma Canguilhem no artigo “Qu'est-ce qu'une idéologie scientifique”, de 1969. "Afinal, não importa, antes de tudo, saber de quê a história das ciências pretende fazer a história?"43 Sim, pois "ciência", diz Canguilhem, não é apenas um título, ou uma rubrica, mas uma reivindicação de dignidade. É preciso saber quais critérios permitem que reconheçamos como ciência um saber ou disciplina que se reivindique enquanto tal. E, ao mesmo tempo, precisamos saber quais relações a ciência mantém com aquilo que ela exclui e, consequentemente, quais relações a história da ciência mantém com a não-ciência. Para

\footnotetext{
${ }^{42}$ BRAUNSTEIN e BING, "Entretien avec Georges Canguilhem", p. 126-27.

${ }^{43}$ CANGUILHEM, "Qu'est-ce qu'une idéologie scientifique", p. 7.
} 
Canguilhem, essas questões não são apenas um problema de técnica ou método histórico, mas um "problema epistemológico concernente ao modo permanente de constituição dos conhecimentos científicos na história" ${ }^{44}$. Canguilhem atribui as seguintes características às ideologias científicas:

a) As ideologias científicas são sistemas explicativos cujo objeto é hiperbólico, relativamente à norma de cientificidade que lhe é aplicada por empréstimo.

b) Sempre há uma ideologia científica antes de uma ciência no campo em que a ciência virá se instituir; sempre há uma ciência antes de uma ideologia, num campo lateral que essa ideologia visa obliquamente.

c) A ideologia científica não deve ser confundida com as falsas ciências, nem com a magia, nem com a religião. Ela é, como as outras, metamorfoseada por uma necessidade inconsciente de acesso direto à totalidade, mas ela é uma crença que se esgueira ["olha de soslaio" é a expressão famosa empregada na tradução portuguesa do livro] ao lado de uma ciência já instituída, a qual ela reconhece o prestígio e a qual ela busca imitar o estilo.

O livro Ideologia e racionalidade na história das ciências da vida, de 1977, foi o último publicado por Canguilhem. Não que ele tenha interrompido sua produção - e há um grande interesse, especialmente da parte dos filósofos da medicina, pelos trabalhos de Canguilhem após sua aposentadoria da Sorbonne e do Institut d'histoire des sciences et des techniques em 1971 -, mas esse livro, que reúne artigos e textos de conferências divulgados entre 1969 e 1976, marca a conclusão de um projeto. "É preciso terminar por onde começamos, e propor uma teoria da história das ciências que esclareça a prática", escreveu ${ }^{45}$. Aos 72 anos, Canguilhem apresentou seus principais conceitos operatórios para história das ciências: a ideologia científica e a ideologia médica.

Dizemos dois conceitos porque, diferente do modo como se vem comumente interpretando os textos reunidos nesse livro, acreditamos que a ideologia médica merece ser tratada como mais do que um simples caso especial da ideologia científica. A ideologia médica é um conceito com função e estatuto próprios. Em primeiro lugar, não tratamos uma ideologia médica como uma ideologia científica encontrada no campo médico, porque, tese canguilhemiana, apresentada já no Ensaio de 1943, a medicina opera uma inversão na tradicional dinâmica reconhecida às ciências e às técnicas. A medicina não é pura aplicação de conhecimentos biológicos. É a técnica, isto é, a clínica, que determina os problemas das ciências biológicas. Por isso Dominique Lecourt pôde afirmar que o pensamento médico se enraíza na relação entre o médico e o paciente - ideia especialmente válida para o pensamento médico contemporâneo, posto que a clínica não é consubstancial à medicina, ela não nasceu com

\footnotetext{
${ }^{44}$ Ibidem, p. 34.

${ }^{45}$ CANGUILHEM, "Qu'est-ce qu'une idéologie scientifique”, p. 44.
} 
Hipócrates, mas há relativamente pouco tempo, como nos ensinou Foucault em $O$ nascimento da clínica. Em segundo lugar, aquela reflexão entre técnica e ciência, entre clínica e ciências da vida, assume, no pensamento de Canguilhem, a forma de uma reflexão sobre a relação entre história da medicina e história das ciências. Embora o objeto de Canguilhem seja a medicina científica, a história da medicina não é a história da aplicação técnica dos conhecimentos da biologia. Assim, embora o recurso à ideologia por Canguilhem tenha o objetivo de discutir a função que as ciências ou a técnicas desempenham em determinados tipos de sociedade, parecenos que a lógica interna da obra de Canguilhem nos autoriza a refletir separadamente sobre as ideologias científicas e as ideologias médicas. Ademais, do ponto de vista de uma história intelectual desses dois conceitos, mostraremos que ideologia científica é provavelmente o mais francês dos conceitos de Canguilhem, nascido de debates localizados em Paris durante a década de 60, enquanto ideologia médica é um conceito elaborado por Canguilhem a partir das suas leituras da chamada "escola germano-americana de história da medicina", notadamente dos trabalhos de Sigerist e Erwin Ackerknecht.

No prefácio a Ideologia e racionalidade na história das ciências da vida, Canguilhem explica que foi primeiro nas suas aulas que introduziu o conceito de ideologia científica, exatamente dez anos antes. De fato, no ano universitário 1967-68, Canguilhem ofereceu pela primeira vez o curso intitulado "Histoire des théories et des idéologies scientifiques modernes et contemporaines", naquele ano, particularmente centrado na história da psicologia. A primeira aula começa com uma reflexão sobre o percurso que inicia: "Por que esse título para um novo curso? Para distinguir adequadamente aquilo que é frequentemente confundido em história das ciências: história das ciências stricto sensu e a história dita das ideias." ${ }^{~}{ }^{4}$ Afinal, e esses são seus primeiros exemplos da distinção proposta, existe a ciência da eletricidade e existe o eletrismo; a história dos fenômenos magnéticos e a história do magnetismo. Encontramos, nos manuscritos referentes a esse curso, a primeira definição do conceito de ideologia científica: "Ideologia é o debordamento de uma teoria científica para fora de um campo inicial" ${ }^{47}$.

Fora de seu campo de desenvolvimento, sem o controle da suspeição, a teoria se
torna ideologia na medida em que ela perde todo o controle, toda restrição, quer
dizer, na medida em que ela é utilizada, sob pretexto de sucesso local ou
regional, para interpretar, representar, a totalidade de uma experiência em um
dado momento.
O evolucionismo, por exemplo, é a explicação darwiniana reduzida à sua
conclusão (derivação histórica das estruturas orgânicas) - abstração feita de seu

${ }^{46}$ CANGUILHEM, "Histoire des théories et des idéologies scientifiques modernes et contemporaines", manuscrito, ff. 2.

${ }^{47}$ Idem. 
mecanismo preciso (pequenas variações, concorrência, pressão permanente das interações específicas) - e estendida, extrapolada para tudo: as formas sociais, as línguas, as técnicas, as artes etc.

Porque essa extensão: em geral, porque existe uma demanda de interpretação, de representação, uma necessidade histórica; mas para qual finalidade, para qual serviço?

A finalidade da extrapolação e o serviço que presta a extrapolação são uma finalidade e um serviço prático.

Para o evolucionismo: anti-teleologia: sociedades industriais contra sociedades tradicionais no século XIX. Ideologia como auto-justificação dos valores, dos interesses de uma verdade.

Daí ideologia, no sentido doravante elástico, representação da realidade natural ou social cuja verdade não reside naquilo que ela diz, mas naquilo que ela faz, não naquilo que ela exibe, mas naquilo que ela dissimula. A ideologia é uma teoria confiscada, sem qualquer tipo de responsabilidade especial. ${ }^{48}$

O recurso ao evolucionismo como exemplo tinha um grande mérito didático para apresentação desse novo conceito, a ideologia científica, aos seus alunos. O esclarecimento sobre o papel que as teorias biológicas do desenvolvimento e da evolução desempenharam para a formação de um pensamento social no começo do século XX - o que hoje nos parece uma obviedade - tem uma história. Ela começa em 1955, quando a UNESCO publica Race et histoire, de Claude Lévi-Strauss. Mas 1967 foi o ano da primeira reedição desse texto, agora pela editora Gonthier, o que permitiu que ele alcançasse um número maior de leitores - entre eles, Canguilhem, que deu diversos testemunhos da sua admiração pelo antropólogo estruturalista e dedicou algumas páginas a Race et histoire no artigo "La décadence de l'idée de Progrès". No ano em que Canguilhem apresentou seu conceito de ideologia científica, Race et histoire era objeto de debates públicos nos jornais e nos círculos intelectuais de Paris. A finalidade e o serviço do evolucionismo descritos por Canguilhem no primeiro dia do seu curso são exatamente aqueles denunciados por Lévi-Strauss em seu livro. Conforme Francine Iegelski, autora do livro Astronomia das constelações humanas: reflexões sobre Lévi-Strauss e a história, em Race et histoire Lévi-Strauss mostra como o evolucionismo social abre mão de explicar as diferenças existentes entre as culturas, que são consideradas como meramente aparentes: “Assim o é se, como fazem os evolucionistas sociais, tratarmos os diferentes 'estados' em que se encontram as sociedades humanas como etapas de um desenvolvimento único que, partindo do mesmo ponto, deve convergir para um mesmo fim." 49

No ano universitário seguinte, o curso ministrado por Canguilhem foi dedicado ao evolucionismo, e parte dos seus resultados foi apresentado, em 1971, no XIII Congresso

\footnotetext{
${ }^{48}$ Idem.

${ }^{49}$ LÉVI-STRAUSS, Raça e história, 22.
} 
Internacional de História das Ciências, em Moscou. O texto dessa apresentação foi publicado pela primeira vez no livro Ideologia e racionalidade na história das ciências da vida, com o título "Sobre a história das ciências biológicas depois de Charles Darwin". Canguilhem começa esse artigo mostrando como a comprovação, por Newton, da cosmologia heliocêntrica galileana retardou e refreou tanto a elaboração quanto a aceitação da biologia darwiniana. Canguilhem explica que, na Inglaterra, os Principia de Newton não apenas não causaram qualquer escândalo, como foram facilmente apropriados pelos teólogos, que recorriam a Newton para explicar como o acordo entre as leis da natureza exprimia uma escolha de Deus ${ }^{50}$. Segundo Canguilhem, a comprovação cosmológica de Newton difundiu a impressão de que "as relações do homem com o seu meio, como aliás as relações das outras espécies vivas, pareciam resultar de uma adaptação somente conseguida por uma solicitude toda poderosa" ${ }^{, 51}$. Para que pudesse ser elaborada a ideia de uma transmutação das espécies sem adaptação preordenada, a partir da relação entre a estrutura de cada espécie e seu modo de vida, teria sido preciso, diz Canguilhem, "ocultar, na história natural, alguns reflexos da glória de Newton”. Para Canguilhem isso mostra tanto a existência de diferentes tempos históricos para diferentes disciplinas científicas quanto o procedimento pelo qual se passa da história das ciências à história das ideias.

A história da verdade não é linear e monótona. Uma revolução na cosmologia não implica necessariamente uma revolução análoga na biologia. A história das ciências devia tornar-nos mais atentos ao fato de que as descobertas científicas, numa certa ordem de fenômenos, podem assumir o papel de obstáculo ao trabalho teórico em curso numa outra ordem, o que se deve ao fato de sua possível degradação em ideologias.

Mas também pode acontecer que seja este mesmo trabalho teórico a afetar a forma de uma ideologia, quando do seu início e, sobretudo, nos domínios em que a prova experimental demora a ser instruída. Foi o que aconteceu com a teoria da seleção natural. Para além do fato de que o conceito de seleção passava por ser uma importação desastrosa da prática dos criadores para a teoria biológica, a explicação darwiniana sobre a base da concorrência vital tinha sido anexada por uma teoria inicialmente e aparentemente cosmológica, mas finalmente e fundamentalmente ideológico-política, a teoria que Herbert Spencer tentara elaborar, sob o nome de evolucionismo. Um esboço da história das ciências depois de Darwin deve ter em conta o fato de que, ao contrário da teoria da atração universal, a teoria da origem das espécies por seleção natural foi de início tida na conta de ideologia por um bom número de pessoas, das quais nem todas eram ignorantes. ${ }^{52}$

\footnotetext{
${ }^{50}$ Embora Canguilhem não faça referência a esse texto, vale a pena mencionar, a propósito do tema, o livro Attraction universelle et religion naturelle chez quelques commentateurs anglais de Newton, no qual Hélène Metzger expõe, ao longo de três tomos, as repercussões que a descoberta, por Newton, da lei de atração universal teve sobre o pensamento religioso na Inglaterra.

${ }^{51}$ CANGUILHEM, "Sobre a história das ciências biológicas depois de Charles Darwin", p. 92.

${ }^{52}$ Ibidem, p. $92-93$
} 
Ainda no curso de 1967-68, intitulado Science et idéologie dans la constitution de la psychologie, Canguilhem propõe outro exemplo, além do evolucionismo, que nos parece igualmente exemplar: a própria Ideologia. Não a ideologia derivada da vulgarização do pensamento de Karl Marx, mas aquela filosofia francesa do século XVIII que Marx denunciara. “A ideologia era, segundo Cabanis e Destutt de Tracy, a ciência da gênese das ideias. Seu projeto era tratar as ideias como fenômenos naturais, expressando a relação do homem, organismo vivo e sensível, com seu meio natural de vida" ${ }^{, 53}$. No começo do século XIX, a Ideologia se apresentava como uma nova ciência do cérebro, a partir da publicação, em 1810, de Anatomie et physiologie du système nerveux em générale et du cerveau en particulier, de Franz Josef Gall. A tese central é a de que todas as faculdades intelectuais e morais seriam propriedades inatas contidas no encéfalo e o cérebro seria o suporte físico da tábua das faculdades, excluindo a interferência de qualquer substancialidade ontológica ou transcendental. A ciência inaugurada por Gall seguiu na esteira de Condillac, reduzindo o pensamento e a ação à mera sensação ou ao substrato anatômico de um órgão - o cérebro, no caso - e reafirmando a Ideologia como parte da zoologia. A grande tarefa dessas filosofias era a dedução do espírito humano a um pequeno número de sensações particulares - a partir de órgãos específicos - e isoladas umas das outras. Com isso pretendiam entender como as ações externas se combinam entre si e, fazendo efeito sobre cada um desses sentidos, permitem a formação de juízos morais e do pensamento em geral.

$\mathrm{Na}$ continuidade das suas críticas à psicologia e às ideologias científicas que estão na base da sua constituição enquanto disciplina, Canguilhem também tratou da "psicometria", ideologia científica concebida por Christian Wolff tendo como modelo a fotometria, inicialmente formulada por Kepler. "Wolff achava que a psicometria poderia mensurar as faculdades como a moral ou a razão e os estados afetivos". O naturalismo moral, explica Canguilhem, permite aproximar ideologia e psicometria, mas, dessa vez, não é a fisiologia que serve de base científica: "Moral à imagem da física, moral desligada da relação com a metafísica." 54 Tratava-se, em ambos os casos, de uma proposta de conhecimento objetivo do intelecto, que Canguilhem denuncia enquanto ideologia científica por tentar conferir a uma antiga subdivisão da metafísica, a psicologia, uma base científica. Canguilhem não perde a oportunidade ironizar: lembra que a psicometria de Wolff é frequentemente inscrita na história positiva da psicologia experimental ${ }^{55}$.

\footnotetext{
${ }^{53} \mathrm{CANGUILHEM,} \mathrm{Science} \mathrm{et} \mathrm{idéologie} \mathrm{dans} \mathrm{la} \mathrm{constitution} \mathrm{de} \mathrm{la} \mathrm{psychologie,} \mathrm{manuscrito,} \mathrm{ff.} 35$.

${ }^{54}$ Ibidem, p. 6.

${ }^{55}$ Cf. FEUERHAHN, W. (2003). "Entre métaphysique, mathé- matique, optique et physiologie: la psychométrie au XVIIIe siècle". Revue Philosophique, 3, 279-292. VITTADELLI, A. (1973). "Expérience et raison dans la psychologie de Christian Wolff". Revue Philosophique de Louvain, 71, 488-511.
} 
Mas se esse é o conteúdo das ideologias científicas, qual a sua função? Para explicála, Canguilhem recorre, na parte final do seu curso, à tese de doutorado de um dos seus mais brilhantes alunos: Michel Foucault, autor de Histoire de la folie à l'âge classique:

\section{Pinel visto por Foucault}

Pinel encontrou os loucos como uma população confinada em um espaço social de proteção, de separação. Casas específicas de internamento, esse espaço social povoado pela loucura é ele mesmo o resultado de uma divisão no interior de outro espaço mais vasto, instituído a partir de uma intenção repressiva; o internamento daqueles que se considera como a-sociais, libertinos, pródigos e dilapidadores; "sem trabalho" voluntários ou forçados.

Então, Pinel encontra um objeto que é um objeto social e político, ainda que natural. Ele é constituído em objeto específico por categorias sociais e um pouco de categorias lógicas. É, portanto, um fato ideológico, mais que um fato científico.

O objeto é delimitado pelo direito, quer dizer, pelas instituições cujo motivo profundo é o medo. Alienação: conceito jurídico antes de ser um conceito científico. Pesquisa de critérios médicos subordinados à vontade de interdição jurídica. ${ }^{56}$

A necessidade de distinção entre a função e o conteúdo é um dos principais argumentos de Canguilhem para a inclusão das ideologias na história das ciências. Notamos que no artigo "Qu'est-ce qu'une idéologie scientifique" - e também nesse primeiro curso sobre as teorias e as ideologias científicas contemporâneas - o recurso à Ideologia serve não apenas de exemplo de uma ideologia científica, mas permite uma reflexão sobre essa nomenclatura. Canguilhem quer entender como o termo ideologia foi ressignificado por Marx na forma de sua atual circulação. A ideologia, explica Canguilhem, que "designava em primeiro lugar a aquisição pelo homem de ideias calcadas sobre o próprio real", passa a designar, a partir da obra de Marx, "todo sistema de ideias produzido como efeito de uma situação inicialmente condenada a desconhecer sua relação real com o real. A ideologia consiste no deslocamento do ponto de aplicação de um estudo." 57

Com Marx, a ideologia se torna falsa consciência, uma ilusão, entendida tanto como erro, quanto como uma "fábula reconfortante, uma condescendência inconsciente com um julgamento orientado por um interesse". Canguilhem lembra que, no Manifesto Comunista, a ilusão da classe dominante em tomar por eternas as relações sociais do capitalismo é qualificada como uma "concepção interessada" 58 . Nascidas de situações sociais conflitantes, as ideologias burguesas, para Marx, tendem a negar sistematicamente a existência de tais situações - é o caso

\footnotetext{
${ }^{56}$ CANGUILHEM, Op. cit., p. 30 .

${ }^{57}$ CANGUILHEM, “Qu'est-ce qu'une idéologie scientifique”, p. 36.

${ }^{58}$ Ibidem, p. 37
} 
das economias políticas burguesas, que naturalizam o capitalismo, e também o do evolucionismo tratado por Canguilhem em sua primeira aula, transposto para o campo social (pela pretensão da Sociologia ao estatuto de ciência), que dissimula a ideologia progressista da sua própria sociedade e, assim, transforma aquilo que, na prática é produto de um violento mecanismo de exploração e pilhagem, o par bárbaro/civilizado, em momentos distintos de uma mesma derivação histórica.

O que chama a atenção de Canguilhem é que, em nenhum momento de $A$ ideologia alemã , Marx cita as ciências ao lado das ideologias. Marx estabelece distinções entre a mecânica celeste e a economia liberal, sem nem por isso deixar de notar que as ciências da natureza, as ciências "puras" recebem suas tarefas e seus meios do comércio e da indústria: a constituição da astronomia nos séculos XVII e XVIII está diretamente relacionada às exigências comerciais de navegação. No entanto, diz Canguilhem, as técnicas de satelização artificial e a astronáutica deram uma "gigantesca verificação experimental" à mecânica celeste newtoniana. Para Canguilhem, isso é prova de que a dependência das ciências da natureza dos modos sucessivos de exploração da natureza não significa a recusa da autonomia da sua problemática e a especificidade do seu método. Daí a provocação mordaz contra certa historiografia científica que se reivindicava do marxismo para tratar das ciências:

No livro Contribuição à crítica da economia política, Marx se deparou com o que ele chama de uma "dificuldade", a saber, o fato de que a arte, relativa nas suas produções ao estado social, pudesse conservar um valor permanente, para além das suas condições históricas e mesmo após o desaparecimento delas. Aquilo que Marx consentiu à arte grega, o marxismo poderia recusar à geometria grega $?^{59}$

Em outras palavras, o desaparecimento da função para a qual determinada ciência foi constituída, faz desaparecer também seu conteúdo? Parece ser a expectativa de Marx em relação às ideologias políticas: a revolução do proletariado desvelaria as ideologias e instituiria uma nova relação com o real - expectativa que Althusser estende às ideologias no campo das ciências. Para Canguilhem, supondo que, na sequência de uma revolução social e política, seja instaurada uma nova relação das ciências com a natureza, não parece possível que essa nova relação seja absolutamente desprovida de historicidade, quer dizer, sem relação de continuidade com certos conteúdos da ciência nascida sob o domínio da burguesia. Por isso, "a ideologia científica seria ao mesmo tempo obstáculo e, às vezes, condição de possibilidade para a constituição da ciência. Nesse caso, a história das ciências deveria incluir uma história das ideologias científicas

\footnotetext{
${ }^{59}$ CANGUILHEM, “Qu'est-ce qu'une idéologie scientifique?”, p. 38.
} 
reconhecidas enquanto tais" ${ }^{60}$.

Cabe-nos perguntar: qual a função que o conceito de ideologia científica desempenha na evolução da obra de Canguilhem? É preciso dizer muito claramente: não há unidade na obra de Canguilhem. O que nos leva a falar de um projeto de historicização das ciências é o seu engajamento com certos problemas fundamentais, notadamente o da relação entre ciência e nãociência. A ideologia científica se mantém na continuidade das reflexões sobre história das ciências e história das ideias, que encontramos no Ensaio de 1943, sobre as relações entre conceito e mito no artigo "A teoria celular", de 1946 e 1952, sobre história dos conceitos e história das teorias na tese de 1955 sobre a formação do conceito de reflexo. Antecede, portanto, o seu ingresso na Sorbonne e não se limita ao período em que lá esteve, pois, dos sete artigos reunidos em Ideologia e racionalidade na história das ciências da vida, apenas dois foram publicados antes da sua aposentadoria. Mas esse engajamento não significa, de maneira alguma, a unidade de um pensamento. Estudar historicamente a obra de Canguilhem significa, para aplicar à historiografia das ciências uma imagem que ele atribuiu à história das ciências, perseguir a "edificação difícil, contrariada, retomada e retificada" de um pensamento. Mas a consciência dessa processo não diminui o espanto de quem lê pela primeira vez o prefácio a Ideologia $e$ racionalidade na história das ciências da vida:

Errar é humano, perseverar no erro é diabólico. Não cabe a mim dizer a que grau de aberração se elevam os poucos textos que eu decidi reunir com vistas a uma nova publicação. Não há dúvida de que estou demasiado velho [tinha, à época 72 anos] para renegar, em tom de retratação honorável ou de fidelidade às novas potências de investidura epistemológica, os poucos axiomas metodológicos que tomei emprestado, há quase quarenta anos, para fazê-los valer por minha própria conta e risco, não sem emendas, reexames e mudanças de orientação. ${ }^{61}$

Há quase quarenta anos... Talvez 1939? 1943? De qualquer forma, é o próprio Canguilhem quem fala da continuidade de uma investigação histórica sobre as ciências, para a qual se valeu de diferentes axiomas metodológicos. E é também o próprio Canguilhem quem apresenta, ainda no prefácio, a genealogia do conceito de ideologia científica:

A introdução a partir de 1967-68, no meu ensino ou em alguns artigos e conferências, do conceito de ideologia científica, sob a influência dos trabalhos de Michel Foucault e Louis Althusser, não foi apenas uma marca de interesse e de consentimento a essas contribuições originais em deontologia da história das ciências. Ela foi uma maneira de renovar, sem rejeitar, a lição de um mestre de quem eu li os livros, na falta de ter podido seguir os cursos: a lição de Gaston

\footnotetext{
${ }^{60}$ Idem

${ }^{61}$ CANGUILHEM, Idéologie et rationalité..., Prefácio.
} 
Bachelard, por quem, tomadas algumas liberdades, meus jovens colegas estavam, de fato, inspirados e fortificados.

Não penso, portanto, que o leitor dos primeiros Estudos de história e de filosofia das ciências possa encontrar nos textos que seguem os sinais de uma inflexão ou de uma evolução. Quanto a saber se minha indiferença em relação à gestação de uma história que substituiria a separação entre as ciências e as ideias, quer dizer entre a literatura, pela sua intuscepção recíproca me valeria ou não a qualificação de fóssil conceitual, devo confessar que disso não tenho cura. No momento em que, em seu cantinho de investigações, se reconhece a descontinuidade em história, seria mal visto recusar a descontinuidade em história da história. A cada um sua descontinuidade. A cada um sua revolução no globo intelectual. ${ }^{62}$

Separemos os seguintes enunciados: 1) Canguilhem admitiu ter errado; 2) seu erro é derivado do uso de certos axiomas metodológicos emprestados de Bachelard; 3) os trabalhos de Althusser e Foucault permitiram renovar, sem rejeitar, esses enunciados; 4) Canguilhem não vê uma inflexão ou evolução em relação às teses apresentadas em trabalhos anteriores.

Dissemos anteriormente que Bachelard via a história das ciências como um processo de refinamento dos conceitos no interior de cada ciência particular. Embora rejeitasse enfaticamente os diversos modelos teleológicos que organizavam a História e a Filosofia das Ciências, a concepção bachelardiana de história dos conceitos mantinha em grande parte o seu valor de progresso. E, se "a temporalidade da ciência é um crescimento do número das verdades, um aprofundamento da coerência das verdades" e a "história das ciências é a narrativa deste crescimento, deste aprofundamento" ${ }^{\prime 63}$, o historiador que pretender escrever de fato a história de uma ciência deverá situar-se na modernidade dos seus conhecimentos. Assim ele poderá identificar, no passado, o que realmente pertence à história de uma ciência, o que há de nocivo e fecundo no seu desenvolvimento, como forma de erigir barreiras contra a reativação do irracionalismo superado. Para Bachelard, a consciência de modernidade e a consciência de historicidade são rigorosamente proporcionais, o que significa que o historiador das ciências não deveria se ocupar do momento em que o pensamento estava dominado pela fantasia, pela magia, pela religião, mas apenas do que constitui a história positiva das ciências, após o longo trabalho de retificação e depuração dos conceitos que marca a ruptura entre o senso comum e o pensamento científico.

Acrescente-se a isso o fato de que história das ciências escrita por Bachelard ainda tinha uma personagem bastante kantiana: a Razão. Para Bachelard, os elementos nocivos ao pensamento científico inscreviam-se no próprio ato de conhecer, como um procedimento equivocado da Razão em relação a si mesma, que erigia obstáculos epistemológicos. Bachelard

\footnotetext{
${ }^{62}$ CANGUILHEM, Idéologie et rationalité..., Prefácio.

${ }^{63}$ BACHELARD, "L'actualité de l'histoire des sciences", p. 148.
} 
colocou pela primeira vez a necessidade de pensar conceitualmente a relação da história da ciência com a da não-ciência. Mas ao formular o conceito de "obstáculo epistemológico" como uma barreira do pensamento ao pensamento instaurada no próprio Sujeito, proibiu que a nãociência tivesse uma história. "É preciso dizê-lo claramente: o único elemento que permite a Bachelard pensar a necessidade dos 'obstáculos epistemológicos' é uma certa concepção da alma humana", alertou Dominique Lecourt ${ }^{64}$. Assim, as condições antigas do devaneio não seriam jamais totalmente eliminadas pela formalização das ciências porque tais condições não teriam uma formação discursiva. Ao contrário das ciências, elas se inscreveriam no próprio espírito do cientista. "Imediatamente, o recurso à libido dos cientistas para explicar a constituição dos obstáculos epistemológicos tem completa razão de ser", argumenta Lecourt. O conceito de obstáculo epistemológico “dissimula a impossibilidade, em que Bachelard se encontra, de pensar a história diferencial do que nós [althusserianos] chamamos as ciências e as ideologias" ${ }^{65}$ Dessa forma, a "psicanálise do conhecimento objetivo", disciplina fundada por Bachelard em 1938, testemunha essa impossibilidade de resolver satisfatoriamente uma questão inovadora para a qual ele mesmo tinha contribuído de maneira fundamental.

Para Bachelard, as trevas espirituais, essas aberrações subjetivas das quais os cientistas têm a obrigação de se desvencilhar, possuem uma sólida estrutura, elas são "um conjunto de erros positivos, tenazes, solidários" ${ }^{\prime 66}$, e é por isso que a história das ciências possui uma positividade particular. Como a ciência, para Bachelard, evolui no sentido de um progresso manifesto, a história das ciências só pode ser a determinação dos sucessivos valores do progresso do pensamento científico. Temos, portanto, dois sentidos de progresso: o da ciência e o da história, quer dizer, o aprofundamento da coerência das verdades científicas e a narrativa desse aprofundamento. $\mathrm{O}$ historiador não pode escrever a história de uma falsa ideia senão para mostrar o momento de sua superação. Ele tem uma função bastante específica na cultura científica: barrar a reativação do nosso passado de irracionalismo, defender a todo tempo as conquistas do espírito científico. Daí a história das ciências desempenhar a função de um tribunal da razão, e o racionalismo de Bachelard ter sido descrito por Canguilhem em termos trotskistas, como uma atitude de "revolução permanente"

Mas vimos, no capítulo anterior, que Canguilhem nunca aderiu integralmente à concepção bachelardiana do processo de retificação dos conceitos científicos como história de um refinamento progressivo da razão, mesmo em La formation du concept de réflexe aux XVIIe et

\footnotetext{
${ }^{64}$ LECOURT, Para uma crítica da epistemologia, p. 31.

${ }^{65}$ LECOURT, Para uma crítica da epistemologia, p. 32.

${ }^{66}$ BACHELARD, A filosofia do não, p. 164

${ }^{67}$ CANGUILHEM, "Préface", In: BACHELARD, L'engagement rationaliste, p. 6.
} 
XVIIIe siècles, onde afirma que seu objetivo é "contribuir com a constituição, no que concerne à biologia, daquilo que nós chamamos, com o Sr. Bachelard, 'uma história recorrente, uma história que nós podemos esclarecer pela finalidade do presente'." Também já havíamos mostrado que Canguilhem lidou, nos anos 40 e 50, de maneira diferente com a psicologia dos cientistas, mas, não inconscientemente, também não levou até o fim a historicização da não-ciência. Afinal, em "A teoria celular", Canguilhem defendeu que não se deve desvalorizar radicalmente as antigas intuições sob o pretexto de uma ultrapassagem teórica, quer dizer, que "os temas teóricos sobrevivem à sua destruição aparente que uma polêmica e uma refutação se gabam de haver obtido", porque, assim como Bachelard, explicava a relação entre ciência (conceito) e não-ciência (imaginação) através da psicanálise do conhecimento. Dessa forma, também para Canguilhem, as condições antigas do devaneio não seriam jamais totalmente eliminadas pela formalização das ciências porque tais condições não teriam uma formação discursiva e, portanto, não teriam uma formação histórica. Não à toa Canguilhem concluiu seu artigo “A teoria celular" com uma citação de Jung:

Mesmo a atividade mais livre do espírito, a imaginação, nunca pode divagar na aventura (embora o poeta tenha a impressão disso), ela permanece ligada às possibilidades performáticas, prototípicas, arquetípicas, ou imagens originais. Os contos dos povos mais longínquos desvelam, pela semelhança de seus temas, essa sujeição a algumas imagens primordiais. Mesmo as imagens que servem de base às teorias científicas se mantêm nos mesmos limites: éter, energia, suas transformações e sua constância, teoria dos átomos, afinidades etc. (C. G. Jung. Types psychologiques. Trad. De Le Lay. Genebra, 1950. P. 310).

Quando, na década de 50, Bachelard passou a insistir sobre a marca profunda da sociedade sobre as ciências, jamais abriu mão daquilo que, em Bachelard: Le jour et la nuit, Dominique Lecourt chamou "método de julgamento vertical dos saberes". Para Bachelard, por mais que a ciência estivesse vinculada a uma base social, o julgamento da atividade científica e do progresso da ciência são determinados por seus princípios racionais, única maneira de superar a força do imaginário sobre a determinação científica da matéria. Lembremos que, para Bachelard, é apenas a coesão da cidade científica que permite eliminar "toda aberração derivada do caráter subjetivo de tal ou tal investigador". Mas, argumenta Lecourt,

se se relaciona a noção de "relação imaginária" não a uma psicologia do imaginário mas ao conceito científico de ideologia, tal como aparece no "materialismo histórico", na ciência da história, e que designa precisamente a "relação imaginária dos homens às suas condições de existência", compreende-se então o que é designado, mas não pensado por Bachelard: a necessidade, para construir o conceito duma história das ciências, de a referir a 
uma teoria das ideologias e da sua história. ${ }^{68}$

Quando Althusser transmuta o conceito bachelardiano de "ruptura" em "corte epistemológico", seu objetivo é aprofundar a descontinuidade em história das ciências, fazendo do corte a passagem do ideológico ao científico. Para Althusser, como já dissemos, a ciência se constitui a partir do momento em que, pela verificação experimental, ela se livra de qualquer traço ideológico. Ora, para Canguilhem, o problema central dessa tese althusseriana reside na indistinção entre função e conteúdo das ideologias. Em Althusser, o elemento último de verificação da cientificidade de uma teoria passou a ser determinado pela sua relação com a ideologia de classe (que estaria em contradição com a formalização). Althusser recorria à epistemologia e à história das ciências para localizar o que havia de científico e de ideológico em determinada teoria e, dessa forma, a denúncia da função ideológica de determinada ciência condenava todo o conteúdo dessa ciência anterior à sua formalização. Na introdução ao livro Ideologia e racionalidade na história das ciências da vida, Canguilhem concedeu a Lecourt que Bachelard manteve-se "prisioneiro das implicações idealistas da filosofia das ciências". No entanto, não concordava com a solução apresentada, isto é, não concordava que, sendo a produção dos saberes uma prática social, "o julgamento desses saberes quanto à sua relação com as suas condições de produção diz respeito, de fato e de direito, à teoria da prática política, isto é, o materialismo marxista repensado por Althusser e sua escola"69. Denunciava, assim, a impossibilidade de conservar o nome "ciência" para um gênero de produção cujo elemento último de verificação seria a política.

A dificuldade com a qual se depara Canguilhem é, portanto, saber como sustentar a ideia de que não existe verdade que não seja científica, sem deixar de conceder um estatuto positivo à não-ciência, quer dizer um lugar para a não-ciência na história das ciências. Para fazêlo, Canguilhem recorreu aos trabalhos de Foucault, mais especificamente ao livro A arqueologia do saber, onde Foucault (que também fora aluno de Althusser) tenta compreender as relações entre ciência e não-ciência. Num dos capítulos do livro, chamado "Ciência e Saber", Foucault passa à análise da relação entre o saber e a ideologia:

Se a questão da ideologia pode ser proposta à ciência, é na medida em que esta, sem se identificar com o saber, mas sem apagá-lo ou excluí-lo, nele se localiza, estrutura alguns de seus objetos, sistematiza algumas de suas enunciações, formaliza alguns de seus conceitos e de suas estratégias; é na medida em que, por um lado, esta elaboração escande o saber, o modifica, o redistribui, e, por outro, o confirma e o deixa valer; é na medida em que a ciência

\footnotetext{
${ }^{68}$ LECOURT, Para uma crítica da epistemologia, p. 32

${ }^{69}$ CANGUILHEM, Idéologie et rationalité..., p. 27-28.
} 
encontra seu lugar em uma regularidade discursiva e, por isso, se desdobra e funciona em todo um campo de práticas discursivas ou não. Em resumo, a questão da ideologia proposta à ciência não é a questão das situações ou das práticas que ela reflete de um modo mais ou menos consciente; não é, tampouco, a questão de sua utilização eventual ou de todos os empregos abusivos que se possa dela fazer; é a questão de sua existência como prática discursiva e de seu funcionamento entre outras práticas. ${ }^{70}$

Em 1978, portanto um ano após a publicação de Ideologia e racionalidade na história das ciências da vida, Gabriel Gohau entrevistou Canguilhem a propósito do conceito de ideologia científica, recebido com estranheza entre seus leitores e alunos. Essa entrevista, embora breve, resume bem o problema que esse conceito apresenta para a epistemologia e para a história das ciências. Lembrando que, segundo Canguilhem, "sempre há uma ideologia científica antes de uma ciência no campo em que a ciência virá se instituir", Gohau quer saber quais relações a ideologia mantém com o "pré-científico". Canguilhem explica que seu objetivo principal ao propor o conceito de ideologia científica era mostrar que a ciência não é o produto, "suposto teoricamente puro", de uma operação de conhecimento livre de relações de ancoragem no sistema das práticas. Enfim, tratava-se de mostrar que "as condições de formação de um saber dito científico não são necessariamente situadas onde elas são percebidas”. Questionado diretamente por Gohau sobre a ideia de que a formalização ou racionalização eliminam a ideologia do interior de uma ciência, Canguilhem respondeu, afirmando repercutir uma tese de Foucault com a qual estava inteiramente de acordo, que "a racionalização de um setor do saber não implica necessariamente na eliminação radical da ideologia" ${ }^{71}$. O que destitui uma ideologia não é a sua denúncia enquanto tal e uma consequente depuração da ciência na qual ela se imiscuía, mas o fato de que uma ciência vem ocupar seu lugar. Não o lugar indicado pela ideologia, mas o lugar deixado pelo deslocamento da ideologia e a delimitação de um novo campo de estruturação dos objetos, de sistematização de enunciados, de verificação das provas e de formalização dos conceitos.

Nesses termos, Canguilhem continua, “a ideologia não consiste apenas naquilo que é abandonado (por rejeição do pré-científico ou do não-científico), ela é em primeiro lugar aquilo que foi antecipado". Ao falar da ideologia científica como antecipação, e não apenas como superação, Canguilhem resolvia uma dificuldade legítima apontada por Althusser e os althusserianos, mas cuja solução por eles apresentada era puramente ideológica. "A ideologia científica", diz Canguilhem, "não é uma falsa consciência, como o é uma política de classe" 72 .

\footnotetext{
${ }^{70}$ FOUCAULT, L'Archéologie du savoir, p. 241-242

${ }^{71}$ GOHAU, "Entretien", p. 54.

${ }^{72}$ CANGUILHEM, Op. cit., p. 36.
} 
Também não é uma falsa ciência, pois as falsas ciências não reconhecem a necessidade de renunciar aos bens que considera adquiridos, não sente necessidade de se retificar - "em resumo, a falsa ciência não tem história". E a ideologia científica não é anti-ciência, pois ela tem a ambição de ser uma ciência, mesmo que por imitação de uma ciência já constituída; ela reconhece a dignidade da ciência, dignidade que pretende reivindicar para si - nasce, portanto, depois da crítica da religião, da crença, da superstição.

Para retomarmos algumas ideias expostas no capítulo anterior e marcar bem a continuidade da reflexão de Canguilhem, podemos dizer que as ideologias científicas nascem com a inauguração de uma tendência, que a ideologia científica é o produto daquilo que, em "A teoria celular", Canguilhem chamava de sonho teórico. Como sustentação para essa interpretação, propomos o fato de que, no artigo de 1969 sobre o conceito de ideologia científica, Canguilhem retornou a Vénus physique, de Maupertuis, não mais para indicar o destino da leitura feita por Buffon, mas para demonstrar como a teoria da hereditariedade mendeliana destituiu uma ideologia. Segundo Canguilhem, a grande maioria dos historiadores da biologia via em Maupertuis pressentimentos da genética porque ele teria se preocupado com o mecanismo de transmissão dos traços morfológicos normais e das anomalias, teria invocado o cálculo das possibilidades e explicou os fenômenos de hibridação pela suposição de elementos hereditários, os átomos seminais. Mendel, por sua vez, rompeu com esse interesse pela hibridação, fazendo dele apenas um instrumento de análise, um fato teoricamente orientado pelo conceito de carácter. Mendel, diz Canguilhem, não se interessa "pela sexualidade, nem pela questão do inato e do adquirido, da pré-formação ou da epigênese, ele só se interessa em verificar, através do cálculo das combinações, as consequências da sua hipótese" ${ }^{73}$.

Canguilhem ainda associa a ideologia da transmissão hereditária no século XVIII às diversas exigências da sociedade que lhe deu origem. A curiosidade insistente sobre a produção de híbridos animais ou vegetais, ou sobre a aparição das monstruosidades, com o aparente interesse científico de decidir entre ovismo e animalculismo, permitia, afirma Canguilhem, “encontrar soluções para problemas jurídicos de subordinação dos sexos, de paternidade, de pureza de linhagens, de legitimidade da aristocracia”. Da mesma forma, a técnica de hibridação "era sustentada tanto pelo interesse dos agrônomos, à procura de variedades vantajosas, como pelo interesse dos botânicos, pela determinação das relações entre as espécies”. O mais importante, no entanto, é que a ciência de Mendel não se situa mais no mesmo campo de produção de objetos ou sistematização de enunciados da ideologia da transmissão hereditária do século XVIII. Conclusão: “a qualificação como ideologia de um determinado conjunto de

\footnotetext{
${ }^{73}$ CANGUILHEM, Op. cit., p. 38.
} 
observações e de deduções é posterior à sua desqualificação como ciência por um discurso que delimita seu campo de validade e que dá as suas provas pela coerência e pela integração dos seus resultados".

Podemos retomar o evolucionismo, tema de um dos cursos de Canguilhem, como exemplo de comprovação dessa tese. Afinal, a desqualificação como ciência de certas ideias de Herbert Spencer, que pretendeu formular uma "lei mecânica do progresso universal, por evolução do simples para o complexo, através de sucessivas diferenciações”, igualmente válida tanto para formação do sistema solar quanto para os organismos complexos, incluindo o homem e, por extensão, a humanidade encarnada na sociedade, antecede em muito a sua denúncia como ideologia científica. Essa denúncia foi feita por Lévi-Strauss, que, em Race et histoire, deixou claro que a ideologia evolucionista apareceu muito tempo antes das grandes descobertas científicas de Darwin: "Os dois fundadores do evolucionismo social, Spencer e Tylor, elaboram e publicam a sua doutrina anteriormente à Origem das Espécies ou sem ter lido esta obra" ${ }^{\wedge 4}$. Dessa forma, Lévi-Strauss condenava o evolucionismo, sem condenar a ciência da evolução. ${ }^{75}$ A transformação da ideologia evolucionista, que pretendeu ter encontrado uma comprovação científica na teoria biológica de Darwin, em fato de explicação da experiência social teria, para Canguilhem, uma finalidade "de ordem prática":

A ideologia evolucionista funciona como auto-justificação dos interesses de um tipo de sociedade, a sociedade industrial em conflito, por um lado com a sociedade tradicional e, por outro, com a reivindicação social. (...) Bem entendido, o evolucionismo do século XIX não se resume à ideologia spenceriana. No entanto, esta ideologia coloriu mais ou menos acentuadamente as investigações de linguistas e etnólogos, investiu o conceito de primitivo com um sentido durável, e deu paz de consciência aos povos colonizadores. Encontramos ainda reminiscências desta ideologia na conduta das sociedades avançadas relativamente às sociedades ditas "em vias de desenvolvimento" mesmo agora [o texto é de 1969, mesmo ano do curso dedicado ao evolucionismo] que a etnologia culturalista, ao reconhecer a pluralidade das culturas, pareceu interditar a qualquer uma delas o erigir-se em norma de apreciação e medida de êxito das outras. Ao liquidar as suas origens evolucionistas, a linguística, a etnologia e a sociologia contemporâneas apresentaram uma espécie de prova do fato de que uma ideologia desaparece quando mudam as suas condições de possibilidade histórica. A teoria científica da evolução não ficou pelo darwinismo, mas o darwinismo é um momento integrado da história da constituição da ciência da evolução. Ao passo que a ideologia evolucionista é um resíduo inoperante da história das ciências

\footnotetext{
${ }^{74}$ LÉVI-STRAUSS, Raça e história, 22.

${ }^{75}$ Cf. IEGELSKI, Astronomia das constelações humanas: Claude Lévi-Strauss e a história. São Paulo: Humanitas, 2016 (no prelo).
} 
humanas do século XIX. ${ }^{76}$

${ }^{76}$ CANGUILHEM, Op. cit., p. 40. 


\section{Capítulo 4 \\ Existe uma escola francesa de história da medicina?}

No livro Histoire des sciences médicales, publicado em 1870, Charles Daremberg lembra que, na França, na Escola de Saúde reorganizada pela Revolução existiam três cadeiras dedicadas ao estudo histórico da medicina: "Medicina legal e história da medicina", "Bibliografia médica" e "Doutrina Hipocrática". Em 1823 essas três cadeiras foram reunidas em uma só, "Bibliografia médica", extinta em 1830, com a morte do seu Professor Titular, Moreau de la Sarthe. Em 1837, Eugène Dezeimeris, então bibliotecário da Faculdade de Medicina e fundador, ao lado de Littré, da revista médica L'Expérience, reivindicou por meio de uma carta pública o restabelecimento do ensino de História da Medicina, argumentando que sua necessidade era manifesta pelo fato de ser a medicina uma disciplina "na qual a experiência é proibida pela própria natureza do seu objeto". A ideia foi ganhando simpatia entre os círculos médicos de Paris e uma moção favorável chegou a ser aprovada pelo Congresso Médico de 1845. No entanto, a medicina experimental de Claude Bernard e seu desprezo pela história da medicina, que, em sua opinião, nada exibiam senão os erros e os fracassos dos sistemas médicos do passado, dificultaram a sustentação daquele argumento e frearam os esforços para o estabelecimento da disciplina.

A cadeira de História da Medicina na Universidade de Paris só seria criada em 1870, por pressão dos Positivistas, notadamente de Émile Littré, que jogou um importante papel para a nomeação de Daremberg ao cargo. No Essai sur la détermination et les caractères des périodes de l'histoire de la médecine, Daremberg, ecoando as ideias de Comte, afirmava a existência de uma lei do desenvolvimento necessário do espírito humano. Para ele, "se a ciência da medicina não quer ser rebaixada à categoria de ofício, ela deve se ocupar da sua história e preservar os velhos monumentos que lhe foram legados pelos tempos passados". Para Daremberg, o objetivo do historiador da medicina era "seguir o desenvolvimento do espírito humano no tempo", demonstrável em sua relação com o desenvolvimento das outras ciências. Assim, fazendo provas desse desenvolvimento do espírito, a história da medicina na França era, na virada do século, uma disciplina digna de grandes honrarias. Em pouco tempo, esse sucesso institucional chegaria a outros países da Europa e atravessaria o Atlântico em direção aos Estados Unidos. É aí que entra em jogo uma personagem bastante conhecida da historiografia médica brasileira: a Rockefeller Foundation ${ }^{1}$.

${ }^{1}$ Recomendamos, a propósito dessa questão, mais especificamente para o caso paulista, o livro Caminhos $e$ 
Nas palavras de José Ricardo Ayres, "quem quer que se proponha a compreender as práticas de saúde brasileiras, seja em sua atualidade, seja no seu processo de conformação técnica e institucional ao longo do século XX, sempre encontrará uma referência ineludível: a Fundação

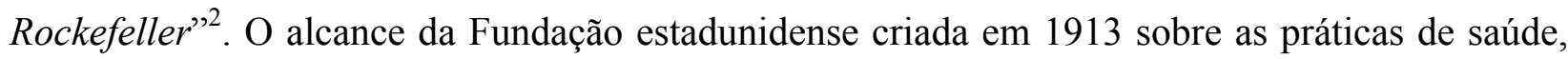
notadamente de saúde pública, não se limita aos seus aspectos científicos e institucionais, mas também atinge, ainda nas palavras de Ayres, sua "própria concepção fillosófica, política e técnica". Uma das várias provas disso foi o interesse da Fundação pela profissionalização da história da medicina nos Estados Unidos.

Em 1925, William Henry Welch escreveu sua "Proposal for the establishment of an Institut of the History of Medicine at the Johns Hopkins University". A construção de um instituto de história da medicina no interior de uma das mais importantes faculdades médicas do Continente tinha, para Welch, um duplo objetivo: fazer frente ao sentimento triunfalista da medicina do período e também à crescente especialização dos médicos. Welch temia que a nova geração de especialistas que sucedia a antiga, e erudita, geração de médicos estadunidenses transformasse a figura do médico na de um mero técnico especialista, "desprovido da formação cultural e intelectual tão necessária para o alargamento da influência do médico". Para ele, a história da medicina garantiria o "toque humano" na formação científica, necessário para "fazer do médico um gentleman da cultura"3.

O Conselho de Educação Geral da Fundação Rockefeller aprovou a proposta de Welch e garantiu o financiamento para a criação do Hopkins Institute of the History of Medicine e, em 1929, do Department of the History of Medicine, mais antigo e tradicional departamento de história da medicina do Continente e também do mundo anglófono. Num primeiro momento, por exigência do Conselho, o próprio Welch dirigiu o Instituto, enquanto procurava um diretor permanente. Sigerist foi a terceira opção, depois que Charles Singer e Harvey Cushing recusaram o convite. Quando assumiu a direção do Instituto, em 1932, Sigerist tentou reproduzir nos Estados Unidos o programa que havia desenvolvido para o Instituto em Leipzig, e até conseguiu levar um de seus mais proeminentes alunos, Owsei Temkin, para trabalhar como seu assistente e dividir a responsabilidade pelo ensino de história da medicina. No primeiro ano nos Estados

trajetos da filantropia científica em São Paulo: A Fundação Rockfeller e suas articulações no ensino, pesquisa e assistência para a medicina e saúde (1916-1952), organizado por Maria Gabriela S.M.C. Marinho e André Mota, publicado em 2013 como terceiro volume da "Coleção Medicina, Saúde e História", editada pelo Museu Histórico da Faculdade de Medicina da USP.

2 AYRES, "Prefácio", p. 7. In: MARINHO e MOTA, Caminhos e trajetos da filantropia científica em São Paulo.

3 WELCH, "Proposal for the establishment of an Institut of the History of Medicine at the Johns Hopkins University", p. 1-3, passim. In: FEE e BROWN, "Using medical history to shape a profession", p. 151. 
Unidos, Sigerist ofereceu seminários sobre problemas de história da medicina, da anatomia, da fisiologia e, claro, sobre a relação entre civilização e doença, dando continuidade àquelas investigações parcialmente publicadas no Introduction à la médecine.

No ano universitário seguinte, 1934-1935, Sigerist havia organizado cursos diferentes para cada ano da formação em medicina, verticalmente estruturados, começando pela medicina grega e seguindo por diferentes aspectos da história da medicina e da farmacologia. Em 19351936, Sigerist obteve uma bolsa da Fundação Rockefeller para a criação de duas novas disciplinas: "Aspectos sociais da medicina" e uma disciplina organizada em seminários para auxiliar os estudantes na elaboração de pesquisas originas sobre o tema. Nesse mesmo ano, novamente sob os auspícios da Fundação Rockefeller, Sigerist criou um "Fórum de Problemas Sociais", para discussões de temas contemporâneos em relação à saúde pública e aspectos sociais e econômicos da organização dos serviços de saúde, um assunto caro aos médicos nos Estados Unidos naqueles anos da Grande Depressão. Foi nesse período que Sigerist lançou o Bulletin of the Institute of the History of Medicine que, pouco mais tarde, viria a se tornar o órgão oficial da American Association of the History of Medicine.

Dissemos no segundo capítulo que, nos primeiros anos da década de 30, quando presidia e lecionava no Instituto de Leipzig, Sigerist já era reconhecido em toda a Europa pelo seu engajamento na institucionalização e elevação da história da medicina a disciplina de primeiro escalão nas universidades. Mas foi a polêmica inaugurada por Georges Sarton em 1935, através da revista Isis, periódico pioneiro na área de história das ciências, fundado pelo próprio Sarton, que ajudou a consolidar definitivamente o nome de Sigerist como "pai" da moderna história da medicina, tanto por sua intervenção decisiva na guinada social da disciplina, quanto pela sua autonomização enquanto campo de pesquisa independente da história da biologia. No editorial a Isis intitulado "The History of Science versus the History of Medicine", Sarton ressentia-se do fato de que, apesar dos seus esforços, a história das ciências conhecia uma estagnação nas universidades dos Estados Unidos (onde Sarton, nascido na Bélgica, partiu em exílio definitivo pouco após o início da Primeira Guerra), enquanto a história da medicina, ao contrário, ganhava cada vez mais financiamento para a criação de novos espaços institucionais. Sarton acusava Sigerist de uma autoindulgência com seu trabalho que o levava a praticamente defender uma preeminência da história da medicina em relação à história das ciências, enquanto, na sua opinião, "o centro da história da ciência não deveria ser a história da medicina, mas a história da matemática e das ciências matemáticas, e que os outros ramos das ciências deveriam ser trabalhados a partir de seus conteúdos matemáticos"4.

${ }^{4}$ SARTON, "The History of Science versus the History of Medicine", Isis 23 (1035), 317. 
As duas questões - a criação de espaços institucionais de pesquisa dedicados à disciplina e a importância atribuída por Sigerist à história da medicina - estão evidentemente relacionadas (e existe ainda uma terceira, o estatuto epistemológico da medicina), mas não foi apenas o debate teórico sobre o papel das ciências médicas e das ciências matemáticas que ajudou a promover a institucionalização da história da medicina. Poucos meses depois, no quarto número do Bulletin of the Institute of the History of Medicine, Sigerist publicou sua resposta. Se Sarton falava de história das ciências versus história da medicina, Sigerist apostou na complementaridade: "The History of Medicine and the History of Science" foi o título do editorial assinado por ele.

Sigerist respondeu que Sarton estava equivocado já de início, por acreditar que a história da medicina era uma disciplina popular e bem financiada: "É preciso pouquíssimo dinheiro para fazer de um instituto histórico-médico um valioso departamento. Mas você não tem ideia de como é difícil encontrar pouquíssimo dinheiro", Sigerist concedia a Sarton que a História da Medicina era geralmente praticada, naquele momento, de forma amadorística: " $\mathrm{Eu}$ iria mesmo além, e diria que muitos desses artigos e livros são não apenas inúteis, mas criminosos. Eles perpetuam velhos erros e acrescentam novos", escreveu. "Eles são ainda mais perigosos porque são geralmente escritos por médicos eminentes - eminentes em qualquer outra coisa, menos no campo histórico -, o que confere a esses livros e artigos grande autoridade e popularidade" . Não obstante, é preciso dizer, Sigerist nunca pretendeu que a história da medicina devesse ser tarefa de qualquer outro profissional que não o profissional médico. Anos mais tarde, no primeiro volume de sua monumental e inacabada obra $A$ history of Medicine, defendeu que "o historiador da medicina é um médico, treinado na pesquisa dos métodos da história, que assume um papel ativo na vida do seu tempo e está em contato próximo com os problemas médicos do seu tempo". Isso porque, para Sigerist, a história da medicina "não é apenas história, mas também medicina, parte da teoria da medicina"7 . Portanto, para Sigerist, a história da medicina não deveria ser escrita nem por amadores, nem por eruditos descolados da prática e dos problemas reais da profissão médica, entendida não apenas do ponto de vista clínico, mas sobretudo social, econômico e político:

É óbvio que um doutor pode tratar com sucesso um paciente que sofre de pneumonia, de sífilis ou de qualquer outra doença sem qualquer conhecimento da história geral ou da medicina. A única história que ele deve conhecer é a do

\footnotetext{
5 SIGERIST, "The History of Medicine and the History of Science", Bulletin of the History of Medicine, 1936, 4.

${ }^{6}$ SIGERIST, "The History of Medicine and the History of Science", p. 2.

7 SIGERIST, A history of Medicine, v.1, p. 31-32.
} 
seu paciente. No entanto, o momento em que planejamos uma campanha de vacinação contra doenças venéreas ou contra a tuberculose, ou serviços médicos para um distrito rural, ou seja lá o que for - o momento, para dizer em outras palavras, em que dirigimos nossos esforços não para um indivíduo, mas para um grupo -, é quando mais precisamos de conhecimento histórico. O sucesso ou fracasso de nossos esforços pode muito bem depender do fato de termos ou não uma apreciação correta de muitos fatores não-médicos, sociais, econômicos, políticos, religiosos e filosóficos que determinam a situação, uma apreciação que podemos adquirir apenas como resultado de uma análise histórica. (...) Em resumo, podemos dizer que a história médica não é apenas a preocupação da história, não apenas a preocupação em produzir uma imagem mais completa da história da civilização, mas que ela também é medicina, uma abordagem para os problemas da medicina. E o historiador, servindo à verdade enquanto historiador, está se esforçando para contribuir com os progressos da medicina. ${ }^{8}$

Sigerist, em nota a esse texto, comenta que sempre falou sobre os princípios e métodos em história da medicina em momentos decisivos da sua carreira: na sua aula inaugural na Universidade de Zurique, em 1922, na sua aula inaugural em Leipzig, em 1926, no VIII Congresso Internacional de História da Medicina, em 1930, e, finalmente, em 1938, numa conferência para a New York Academy of Medicine. Em todos esses momentos, escreveu, seu objetivo era dizer o mesmo que havia respondido a Sarton, isto é, que a "história da medicina não é um mero capítulo na história da ciência, mas tem problemas próprios" ". De fato, em 1936, a resposta de Sigerist a Sarton, em forma de uma carta aberta, assumiu ares de um manifesto: "Medicina não é um ramo da ciência e nunca será. Se a medicina é uma ciência, então ela é uma ciência social" 10 . Ele explica:

A história da medicina é, em grande sentido, a história das relações entre médico e paciente, entre a profissão médica (...) e a sociedade (...). A mortalidade de um dado período, em outras palavras, a tarefa com a qual o médico está confrontado, é o resultado de infinitos fatores econômicos e sociais. Se você quer entender o desenvolvimento da medicina no século XIX, você terá que estudar primeiro a revolução industrial. ${ }^{11}$

Além de Temkin, outro importante historiador da medicina levado por Sigerist para os Estados Unidos foi Erwin Ackerknecht, que deu continuidade àquela compreensão da medicina como ciência social. Ex-aluno de Sigerist desde o período de Leipzig, Ackerknecht foi um importante historiador da medicina, autor de uma vasta e erudita obra. Nos primeiros anos de trabalho, Ackerknecht, reconhecido militante trotskista desde a juventude, imprimiu uma

${ }^{8}$ SIGERIST, $A$ history of Medicine, v.1, p. 32-33.

9 SIGERIST, A history of Medicine, v.1, p. 34, n. 9.

${ }^{10}$ SIGERIST, "The History of Medicine and the History of Science", p. 4-5.

${ }^{11}$ SIGERIST, "The History of Medicine and the History of Science", p. 5. 
consistente abordagem sociológica à historiografia médica sem nem por isso abandonar o cuidado com as ideias e os textos. Na França, para onde partiu em exílio em 1933 por conta da ascensão do partido nazista na Alemanha, pesquisou e publicou sobre as teorias médicas e a história da terapêutica. Em Paris, Ackerknecht, que já era reconhecido como um dos grandes historiadores da medicina europeus, estudou antropologia social na Sorbonne, sob orientação de Marcel Mauss. Quando partiu para os Estados Unidos, em 1940, passou a publicar sobre a chamada "medicina primitiva", o que lhe garante um papel pioneiro na história da chamada Antropologia da Medicina. A convite de Sigerist, em 1942 Ackerknecht passou a integrar o "grupo alemão" de médicos-historiadores do Instituto na Johns Hopkins, logo se tornando um dos seus mais prolíficos membros. Quando deixou o Instituto, em 1945, para assumir um posto no Museu de História Natural de Nova Iorque, Sigerist lamentou a perda "irreparável" deste "acadêmico maduro e original no pico da sua produtividade". Foi nesse período em Nova Iorque que Ackerknecht publicou seus livros de maior sucesso editorial: A short history of medicine, de 1955, e Medicine at the Paris Hospital, de 1967.

Assim, a escola germano-americana de médicos-historiadores se estabeleceu, de modo pioneiro, nos principais institutos de história da medicina na Europa e América, de Zurique a Leipzig até Baltimore, por onde Henry Sigerist passou, acompanhado de seus discípulos Ackerknecht e Temkin, que ajudaram, através de uma guinada sociológica, a constituir a história da medicina enquanto disciplina autônoma, caracterizada por problemas específicos distintos dos problemas da história das ciências biológicas. Da mesma forma, a obra de Fleck nasce no interior de uma tradição em filosofia da medicina que emerge nas universidades polonesas no final do século XIX, dedicada ao estatuto epistemológico do saber médico, à classificação das doenças e à interação entre ciência e sociedade. Desse lugar institucionalmente reconhecido à história e à filosofia da medicina no interior da formação médica saíram duras críticas à condição a-histórica da teoria do conhecimento do positivismo lógico e, em particular, ao pensamento de Carnap e ao Círculo de Viena. Vale a pena mencionar que, no Brasil, foi também no interior de uma Faculdade de Medicina que se constituiu, a partir dos trabalhos de Cecília Donnangelo e Ricardo Bruno Mendes Gonçalves, uma "escola" na Saúde Coletiva para a qual a reconhecimento do valor epistemológico da historicidade da prática e do pensamento médico constituía um dos traços distintivos.

Quando Sigerist diz que a moderna historiografia da medicina começou na França, justamente com Littré e Daremberg, referia-se ao gênero de história erudita que esses autores inauguraram. Mas referia-se também à sua institucionalização nas Faculdades de Medicina e, consequentemente, ao fato de que foi na França que nasceu essa ideia de que a História da 
Medicina é parte da formação médica, parte da teoria da medicina. Ideia que proliferou na Alemanha, na Polônia e, mais tarde, nos Estados Unidos, onde todos os institutos de História da Medicina foram criados no interior das faculdades de medicina, e assim se mantiveram mesmo depois que as primeiras gerações de médicos-historiadores foram substituídos por historiadores stricto sensu. É o caso, novamente, do Instituto da Johns Hopkins, que, após a aposentadoria de Sigerist, passou a ser dirigido por Richard Harrison Shryock, que não tinha nenhum treinamento médico e havia concluído seu doutorado em História Americana.

À frente do Instituto, Shryock, pioneiro entre os historiadores que se dedicaram à medicina e à saúde pública nos Estados Unidos, aprofundou a guinada sociológica iniciada por Sigerist, que o descreveu como "um historiador social de visão (...), que olhava para a medicina e via muitas coisas que os historiadores da medicina profissionais nunca haviam notado" ${ }^{\text {. }}$ Ocupando a Cadeira que recebia o nome de William Welch, Shryock, enquanto historiador numa faculdade de medicina, deu continuidade às expectativas do criador do Instituto de História da Medicina. Claro, não se tratava mais de "fazer do médico um gentleman da cultura", mas de, através dos estudos históricos, integrar a medicina e o profissional médico a um processo mais amplo de desenvolvimento cultural, econômico e social.

Considerando que a história da história da medicina começou na França, não deixa de impressionar que, um século depois da sua institucionalização, não exista mais nenhuma cadeira dedicada ao seu ensino em qualquer universidade parisiense. O próprio Canguilhem lamentou a desastrosa situação da história da medicina no país, situação pela qual responsabilizava, justamente, o próprio Positivismo. Para Canguilhem, a glória da história da medicina no interior da formação médica chegou ao fim quando "os discípulos do Positivismo esqueceram que o Positivismo consistia, antes de tudo, em colocar em perspectiva histórica as aquisições científicas". Ele explica:

A partir do momento em que se identifica o estado positivo a um estado definitivo do espírito humano, então parece que o período da história chegou ao fim e não há mais interesse pela história. Na medida em que esquecemos que o Positivismo é uma lei do progresso e identificamos o progresso ao últimos dos valores e não à passagem de um valor a outro, a partir desse momento a história não tem mais nenhum interesse porque se acredita estar na terra prometida da verdade científica. (...) Então, o Positivismo é, num primeiro momento, responsável por um certo gosto pela história das ciências no século XIX, mas, num segundo momento, ele consegue matar esse gosto. Aquele que ocupou a Cadeira de História das Ciências no Collège de France, Pierre Lafite, que era um discípulo de Comte, apenas repete de outra maneira as mesmas coisas que Comte havia dito. Ele não trouxe nenhum progresso à história das ciências. Isso

${ }^{12}$ FEE, Making medical history, p. 355 
explica porque, na França, o primeiro e o último historiador da medicina é um só homem, Daremberg. ${ }^{13}$

Assim, enquanto a história da medicina florescia nas faculdades de medicina em outros países, impulsionada pela nova compreensão o papel social do médico e da medicina, na França ela só pôde resistir ao Positivismo enquanto se manteve um exercício de erudição histórico-filológica ou se converteu em prática laudatória dos grandes nomes da história e celebração das conquistas da razão médica em seu último estágio. Já mencionamos a preocupação de Canguilhem, nas primeiras páginas da sua tese de doutorado em medicina defendida em 1943, em não ser confundido com os historiadores: não queria que seus capítulos sobre Claude Bernard ou Leriche fossem confundidos nem com erudição, nem com celebração. O fato de que o Ensaio tenha sido elaborado no interior de uma faculdade médica em nada altera a relação dos médicos com a história da medicina. Na introdução a $O$ normal e o patológico, Canguilhem afirma que o motivo que conduziu um filósofo de formação em direção uma "cultura médica direta" foi o interesse dois "problemas humanos concretos": "o das relações entre as ciências e as técnicas, e o das relações entre as normas e o normal". Igualmente importantes são as razões pelas quais, na opinião de Canguilhem, um filósofo não deveria se interessar pela medicina: "não se trata de dar nenhuma lição, nem de fazer nenhum julgamento normativo sobre a atividade médica. Não temos a pretensão de querer renovar a medicina incorporando-lhe uma metafísica". E conclui: "Se a medicina deve ser renovada, cabe aos médicos a honra e o risco de fazê-lo."14 Quando Canguilhem, ao final de uma longa carreira, foi entrevistado sobre sua relação com a história das ciências, respondeu que "se tratava de utilizar a história das ciências como uma espécie de matéria para a epistemologia" 15 . Vale a pena citar a continuidade dessa entrevista, que permanece inacessível para a quase-totalidade dos pesquisadores:

François Proust: Se você pensa que a história das ciências só tem interesse superior para a epistemologia, entendemos então porque a história da medicina é tão pouco ensinada na Faculdade de Medicina: essa Faculdade não tem por função formar filósofos. Essa história da medicina não tem interesse para o prático?

Georges Canguilhem: Para mim é difícil responder a tal pergunta. O prático, o médico generalista, é um homem que tem muito trabalho, que é sobrecarregado e de quem não se espera que se interesse necessariamente pela história da medicina. Para relaxar, ele pode preferir a história da música ou a história da pintura. Quanto à história da medicina, do ponto de vista da sua formação

\footnotetext{
${ }^{13}$ CANGUILHEM e PROUST, "La médecine et son histoire", p. 42.

${ }^{14}$ CANGUILHEM, Le normal et le pathologique, p. 10, passim.

${ }^{15}$ Idem.
} 
intelectual e enquanto médico, trata-se de saber como se considera a medicina. Se ela é considerada como uma técnica, ainda que uma técnica superior, o médico não tem necessidade da sua história. Mas é um fato que, até uma época recente, os médicos se consideravam não apenas como técnicos, mas como homens cultos a quem a medicina fornecia certa concepção do mundo e do homem. Daí, podemos pensar que havia uma relação normal e natural entre o modo como eles se viam e a história da sua disciplina. Na França isso parece ter existido no século XIX.

François Proust: A história da ciência médica tem algum interesse para o pesquisador?

Georges Canguilhem: Em caso algum ela pode facilitar sua tarefa, pois a história da medicina permanece história ou filosofia, mas, eu acrescento, nenhum historiador pode ignorá-la. Todos os pesquisadores fazem filosofia e sabem muito bem que o fazem. Mas eles o fazem sem buscar obter os meios para fazê-lo. Quer dizer, eles pensam que podem elaborar sua filosofia a partir de sua prática científica, sem perceber que, de fato, eles tomam emprestado de uma espécie de vulgarização filosófica difusa que a história os ajudaria a criticar, ou melhor compreender e retificar. ${ }^{16}$

Quando falou sobre a "escola" uspiana de Saúde coletiva, Mendes Gonçalves, então professor no Departamento de Medicina Preventiva da Universidade de São Paulo, pretendia mostrar como o trabalho recém-publicado de um dos seus alunos prosseguia e superava a "tradição de escola" da qual ambos faziam parte, pretendia mostrar as "potencialidades da individuação no trabalho coletivo", ou ainda, o "modo específico, individual, pelo qual o autor desenvolve algumas características do trabalho coletivo no qual se insere, tratando de evidenciar, pelo contraste e pelos ganhos adquiridos, uma parte dos méritos do seu esforço" ${ }^{17}$. Problema verdadeiro, já que a noção de "escola" encerra, porém concentrados num espaço institucional e corte temporal mais restritos, problemas que história da filosofia e sociologia do conhecimento encontram diante das grandes tradições filosóficas: ou bem se explica Descartes ou bem se explica o racionalismo, por exemplo. Quer dizer, há sempre o risco de, ao adotarmos tal noção, eliminarmos, consciente ou inconscientemente, as particularidades de um autor por respeito aos limites da escola (ou da "tradição", da "rede” etc.). Impossível calcular quantas páginas já foram escritas para dar conta da multiplicidade escondida sob a rubrica "Escola de Frankfurt", cuja unidade foi estabelecida não apenas pela adesão dos seus membros à chamada "teoria crítica", mas também em função da sua designação acadêmica oficial: Instituto de Pesquisa Social (Institut für Sozialforschung). Foi tendo em conta tais dificuldades que Mendes Gonçalves propôs

\footnotetext{
${ }^{16}$ CANGUILHEM e PROUST, "La médecine et son histoire", p. 42.

${ }^{17}$ MENDES GONÇALVES, Prefácio. In: AYRES, Epidemiologia e emancipação.
} 
a seguinte definição:

Uma "escola" de pensamento, investigação e prática educacional não se sustenta, como tantas "igrejas" acadêmicas, na devoção a um referencial teóricometodológico, nem na obsessão por um qualquer desenho de pesquisa, nem na restrição a um particular objeto de interesse, nem tampouco ao que é evidente em qualquer delas: um certo jargão e uma certa forma tendencial de encadeamento lógico entre as proposições isoladas de um discurso e sua estrutura mais geral. Será sempre um certo número, menor ou maior, de construções conceituais, organizadas ao redor e por dentro de certos valores históricos que dará, ao conjunto dos trabalhos que interagem a partir da adesão operativa àqueles valores e conceitos, o caráter de "escola", aquela quase inefável marca registrada que permite ao observador treinado a identificação da origem e do pertencimento de um trabalho isolado qualquer que lhe caia em mãos. Menos do que um paradigma, portanto; mais que uma vocação institucional, por outro lado. ${ }^{18}$

Dissemos, que, de acordo com Christiane Sinding, no Dictionnaire de la pensée médicale, três "escolas", representadas por três autores, marcariam definitivamente a historiografia médica do século XX: as escolas germano-americana (de Sigerist), a polonesa (de Fleck) e a francesa (de Canguilhem). Se uma noção de "escola" como aquela proposta por Mendes Gonçalves parece servir aos dois primeiros casos, não nos parece tarefa fácil comprovar a sua pertinência para o caso francês.

Canguilhem orientou, na Sorbonne e no Instituto de História das Ciências e das Técnicas, os trabalhos de alguns dos principais historiadores da medicina e das ciências da vida da segunda metade do século XX. E sem dúvida poderíamos encontrar pontos em comum entre os trabalhos desenvolvidos por grandes historiadores franceses formados por Canguilhem, como Michel Foucault, Claire Salomon-Bayet e François Delaporte: a compreensão do objeto da história das ciências como um objeto cultural, o interesse não apenas pela história dos conceitos, mas também pelas história das práticas e das instituições, a investigação das condições históricas de possibilidade dos problemas científicos etc. Mas isso seria suficiente para que pudéssemos falar de uma "escola francesa de história da medicina" organizada em torno de Canguilhem? Uma “escola" ao mesmo tempo de pensamento, investigação e prática educacional? Sinding é a primeira a rejeitar essa possibilidade, dados o pouco reconhecimento e os raríssimos espaços institucionais que a história da medicina tem na França, uma situação que, na sua opinião, “contrasta com o renome de dois filósofos que trabalharam com a história da medicina, Georges Canguilhem e Michel Foucault",

\footnotetext{
${ }^{18}$ Idem.

${ }^{19}$ SINDING, “Histoire de l'histoire de la médecine, p. 579
} 
Esse problema tem sido discutido, mais recentemente, a propósito da chamada "escola francesa de epistemologia histórica", frequentemente centrada nas figuras de Gaston Bachelard, Georges Canguilhem e Michel Foucault. Essa designação se tornou particularmente problemática quando se percebeu que, atualmente, a epistemologia histórica é mais reivindicada fora da França. Na Alemanha, Hans-Jörg Rheinberger tem se esforçado para desnacionalizar as origens da epistemologia histórica, argumentando que a primeira metade do século XX foi palco de um processo de "historicização da epistemologia" que se desenvolveu não apenas na França, mas também na Polônia ou na Alemanha. Assim, podemos aí incluir as obras de Ludwik Fleck ou Ernst Cassirer, o que nos convida falar de "epistemologias históricas", no plural. Diante disso, Jean-François Braunstein optou por empregar a expressão "estilo francês" para falar dos trabalhos mais recentes, de autores não-franceses como Lorraine Daston, Ian Hacking ou Wolf Lepenies. Dessa maneira, Braunstein pôde destacar o "ar de família" entre eles a partir de quatro traços fundamentais dessa epistemologia: ela parte de uma reflexão sobre as ciências; essa reflexão é histórica; essa história é crítica; essa crítica é igualmente uma história da racionalidade. A noção de estilo permitiria minimizar as diferenças, mas sem suprimi-las, e universalizar o tema da epistemologia histórica, ao mesmo tempo que individualiza os autores que compartilham esse estilo. Voltaremos, no capítulo seguinte, a essa noção de "estilo francês", mas acreditamos que, em vez de "escola", é muito mais pertinente falar de um "estilo francês de história da medicina" elaborado a partir da obra de Canguilhem, mais especificamente, a partir das respostas elaboradas por Canguilhem àqueles dois problemas humanos concretos jamais abandonadas e constantemente curto-circuitados: as relações entre as ciências (da vida) e a técnica (a medicina) e as relações entre as normas e o normal.

\section{O que é uma ideologia médica?}

Exploramos no capítulo anterior a genealogia francesa do conceito de ideologia científica, informada pelo próprio Canguilhem. Esse conceito é elaborado a partir de questões propostas pelas obras de Althusser e Foucault, numa tentativa de reformar certos axiomas emprestados de Bachelard. Canguilhem, no entanto, não apresentou qualquer filiação para o conceito de ideologia médica. E, como o objeto de Canguilhem sempre foi a medicina científica, a ideologia médica, para muitos comentadores, acabou sendo presumida pela ideologia científica, isto é, como uma ideologia científica aplicada ao campo médico. Mas, em nossa pesquisa nos arquivos pessoais e de trabalho de Canguilhem, encontramos pistas da elaboração do conceito 
que nos remetem a uma tradição constituída fora da França, o que nos permite propor uma reflexão sobre a especificidade da história da medicina em relação à história das ciências, algo ainda pouco problematizado a partir de Canguilhem.

Desde a tese de 1943, Canguilhem praticamente não retornou à obra de Sigerist. São pouquíssimas referências, como uma mera repetição de argumento no artigo "O normal e o patológico", de 1951, mais tarde integrado por Canguilhem em O conhecimento da vida. Sigerist só voltaria a aparecer mais de uma década depois, no artigo "La constitution de la physiologie comme Science", inicialmente publicado em 1963 como introdução ao primeiro tomo da obra Physiologie, dirigida por Charles Kayser (sobre o qual já tratamos no capítulo anterior, a propósito de uma "histoire raisonné" das ciências). Em ambos os casos, a referência é sempre ao livro Introduction à la médecine, o que pode sugerir que a leitura de Sigerist por Canguilhem foi algo episódico, bastante restrito a um momento específico da sua formação.

Porém, de volta aos manuscritos de Canguilhem, percebemos que, no curso de 19661967, intitulado "La physiologie de Harvey à Lavoisier", Canguilhem retorna a uma antiga questão: "Por que a ideia da função penetra na medicina, e precisamente no século XVII?". O objetivo do curso é propor uma reflexão sobre - palavras de Canguilhem - "o problema da delimitação do objeto em história das ciências". Canguilhem retoma, quatro anos depois, a questão indicada no artigo sobre a constituição da fisiologia como ciência, sobre o que permite recortar uma história que vai de Harvey a Lavoisier: "Onde está a unidade desse corte?", pergunta.

Segundo Canguilhem, o que se passa é que, a partir do De motu cordis, de 1628, Harvey constitui um objeto, a hemodinâmica, enquanto nós, historiadores, constituímos, a partir desse mesmo livro, um objeto de natureza diferente, a liberação da fisiologia da dedução anatômica. Para Canguilhem, foram os estudos de Harvey sobre o calor inato que tornaram “possíveis e necessárias" as pesquisas de Lavoisier sobre a origem química do calor animal pela oxidação do sangue. Segundo Canguilhem, "existe uma lógica na sucessão das invenções em fisiologia, mas como essa lógica está espalhada na história, as intercorrências tendem a complicála, a mascará-la". E conclui: "Para fazer a história de uma questão científica, é preciso primeiro buscar formulá-la, e formulá-la na linguagem da época" ${ }^{20}$. Para explicar essa lógica, Canguilhem recorreu a três livros de Sigerist: Introduction à la médecine, Grosse Ärzte (Grandes médicos, livro de muito sucesso e bastante traduzido, publicado por Sigerist em 1931, no qual propõe uma história biográfica da medicina, de Imhotep, no século XXVII a.C., a William Osler, no século $\mathrm{XX}$ ) e On the history of medicine (mais especificamente, o artigo "William's Harvey position in

${ }^{20}$ CANGUILHEM, Curso "La physiologie de Harvey à Lavoisier”, f. 11, passim. 
the history of european thought", já discutido no primeiro capítulo). Portanto, mais de vinte anos após a publicação da sua tese, Canguilhem volta a Sigerist para explorar um tema teórico de história das ciências.

Mais impressionante, no entanto, são as referências encontradas no curso de 19691970, intitulado "L'idéologie médicale au XIX siècle". Pois aqui, novamente num momento decisivo de reflexão teórica sobre a história da medicina, Canguilhem recorre a Sigerist, porém, dessa vez, não mais para pensar a relação entre história da medicina e história das ideias, mas entre história da medicina e história social. O curso começou exatamente assim:

\section{$\underline{\text { Por que ideologia? }}$}

Porque, manifestamente, na medida em que a medicina é uma prática da preservação da saúde por cura da doença, ou por prevenção das doenças, ela não pode ser puramente teórica. A medicina não é constante em seu objeto (curar, impedir), ela está à busca de seus meios teóricos, e essa busca é função de uma

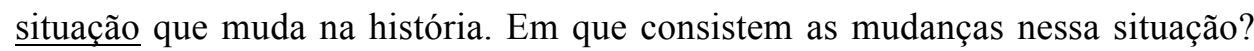
No fato de que as doenças não são unicamente dados permanentes ligados à espécie humana, mas também eventos individuais ou coletivos na civilização.

(Cf. SIGERIST, H. E. Introduction à la médecine, Payot, 1932. Chap. IV, "Maladie"; SIGERIST, H. E. Civilization and disease, 1943, $2^{\mathrm{a}}$ ed. 1962.)

Lembremos o modo como Claude Bernard, em 1865, inaugurou sua Introduction à l'étude de la médecine expérimentale: “Conservar a saúde e curar as doenças: esse é o problema que a medicina se colocou desde a sua origem e para o qual ainda persegue a solução científica." ${ }^{21}$ Mais de um século depois, Sérgio Arouca iniciava sua tese de doutorado sobre o dilema preventivista informando que o atendimento médico sistematizava quatro condutas fundamentadas em vários ramos das ciências: conduta diagnóstica, conduta preventiva, conduta terapêutica e conduta de reavaliação. Essa transformação nos problemas da medicina teria sido motivada, segundo Arouca, pela “compreensão do complexo 'saúde/doença' como um processo no qual um conjunto de fatores interagem na determinação de seu desenvolvimento" 22 . Arouca segue explicando que uma das formas que a conduta preventiva assumiu ao longo da história foi a Higiene, "um novo fenômeno no campo conceitual da área médica", como exigência de "uma sociedade em profundas mudanças decorrentes da chamada revolução industrial” ${ }^{23}$. Naquela entrevista de 1978, Gohau também questionou Canguilhem sobre o conceito de "ideologia médica". Queria saber se a ideologia desempenha na medicina o mesmo papel que desempenha na física ou na biologia. "É ainda pior”, responde Canguilhem. Afinal, a medicina não é apenas

\footnotetext{
${ }^{21} \mathrm{BERNARD}$, Introduction à l'étude de la médecine expérimentale, p. 31.

${ }^{22}$ AROUCA, $O$ dilema preventivista, p. 7.

${ }^{23}$ AROUCA, $O$ dilema preventivista, p. 8.
} 
uma técnica, uma arte de curar os doentes. Se pensarmos nas estratégias de preservação das doenças e da saúde coletiva, ele explica, veremos que a medicina é uma "técnica política".

Claro que Canguilhem não deixaria de recorrer aos trabalhos de Foucault que, já em História da Loucura, deixava claro seu interesse histórico pelas formas de problematização e os processos discursivos de constituição dos objetos científicos. Normal e anormal, razão e loucura não seriam categorias nem oposições naturais, mas uma construção cultural dos saberes que, na modernidade, passaram a tomar o homem como objeto. Nesse livro, interessa a Foucault a transformação da experiência medieval da loucura em doença mental e a emergência de um discurso médico para dar conta desse novo objeto surgido como consequência de certas práticas sociais de exclusão e internamento. Mas é em $O$ nascimento da clínica, livro cuja primeira publicação foi numa coleção dirigida por Canguilhem, que a abordagem pioneira de Foucault forneceria os principais exemplos. Pois, nesse livro, Foucault mostra como a medicina assumiu, a partir do século XVIII, a função de "higiene pública", ultrapassando os limites da morbidade para chegar até os fenômenos ligados à reprodução e à manutenção dos corpos com o objetivo de preservar a força de trabalho. É assim que o processo de medicalização da sociedade se põe em marcha, organizando não apenas os espaços públicos, sobretudo nos centros urbanos, mas também a própria família. Mas o fato de que Canguilhem tenha iniciado seu curso com um comentário sobre a higiene e tenha recorrido a Foucault, não deve levar à conclusão de que as ideologias médicas são fenômenos típicos desses projetos políticos voltados para a saúde pública (Canguilhem rejeitava essa expressão, preferindo usar "salubridade") típicos das sociedades capitalistas. Para Canguilhem, encarada dessa forma, a Higiene é uma ideologia pura e simples. Para Canguilhem, o interesse que a Higiene tem para a demonstração do conceito de ideologia médica não vem do fato de que ela é uma técnica política voltada para as populações, uma estratégia de majoração das forças produtivas, mas o fato de que, enquanto prática de preservação das doenças, exigida por um tipo específico de sociedade, para o exercício de uma determinada função, ela precisou incitar programas de investigação científicas.

Canguilhem, apoiado nos textos de Sigerist, lembra que, desde Galeno, a Higiene se constitui como a ciência das coisas não-naturais, porém, antes do século XVIII, a saúde era entendida como uma qualidade dos poderes de um corpo vivo individual natural frente às coisas não-naturais. O que a Higiene, enquanto disciplina médica, introduz é uma ideia de saúde como a condição e o produto do homem em uma comunidade social. "Já há muito tempo os teóricos da higiene notaram que, segundo a expressão de [Étienne] Tourtelle, 'a maior parte dos males e das enfermidades que nos atingem por todas as partes em nada dependem de nossa organização 
[biológica], mas são nossa própria obra”, disse Canguilhem ${ }^{24}$. É a partir do momento em que essa ideia de saúde é apreendida numa ambição sócio-político-ambiental de intervenção sobre as coisas não-naturais, isto é, sobre a própria civilização, e articulada à exigência de uma medicina científica a partir das novas relações que ela passa a manter com a biologia, que ela se constitui em ideologia médica.

O que mais interessa a Canguilhem em $O$ nascimento da clínica é o fato de que Foucault tentou mostrar como o "olhar médico", o conjunto dos saberes que permitiram a formação de um discurso científico sobre o normal e o patológico do homem, só foi possível graças à criação de uma instituição, o hospital moderno, no contexto político e social da França pós-revolucionária. Em Epidemiologia e emancipação, Ayres fala sobre um elemento fundamental do ideal revolucionário francês, "a estreita relação entre socialidade, saúde e doença, preocupação central da medicina social de Guérin, Virchow e Neumann". Para ele, é a retomada dessa preocupação com o social da saúde, "rearranjada sobre novos axiomas", que explica o alcance do campo da Saúde Coletiva na América Latina. Falando em termos canguilhemianos, Ayres conclui que "a epidemiologia foi o canal através do qual a ideologia científica da medicina social encontrou sua mais expressiva e legítima identidade entre as ciências da saúde”. Ayres está correto ao caracterizar a medicina social como ideologia científica e não como ideologia médica, caracterização que, por sua vez, serve melhor à ideia de saúde em torno da qual a Medicina Social articula seus enunciados.

Encontramos, novamente, agora a propósito da ideologia médica, o problema da distinção entre função e conteúdo. Não é a função que a medicina social ou a epidemiologia, por exemplo, são chamadas a exercer nas sociedades capitalistas que determina o espaço de constituição das ideologias médicas, mas a sua busca pelos meios teóricos para o exercício dessa função. E, tal como as ideologias científicas, a existência de uma ideologia médica não exclui necessariamente a cientificidade. É o que podemos apreender da explicação de Ayres sobre a epidemiologia, que, "nascida das transformações ocorridas nas práticas de saúde quando do nascimento das sociedades modernas, (...) tornou-se o saber que mais positivamente metabolizou os ideais revolucionários da medicina social”. Mas é sem dúvida desse fundo ideológico que resultam as principais dificuldades de estabelecimento do perfil epistemológico da epidemiologia, desde a constituição do seu objeto até a elaboração de um método para produção de conhecimento. É a tentativa de produzir, por meio de procedimentos científicos muitas vezes tomados por empréstimos das ciências biológicas ou físico-químicas para as quais "olha de soslaio", um conhecimento válido sobre um objeto que carrega de forma indelével as marcas do

\footnotetext{
${ }^{24}$ CANGUILHEM, "L’idéologie médicale au XIX siècle", manuscrito, f. 15-16.
} 
seu nascimento histórico que constituem, nas palavras de Ayres, "a nobreza e a miséria" da epidemiologia.

Também é possível trazer o problema da ideologia médica para o campo da saúde individual, deslocando o foco da prevenção para a terapêutica. É aqui, talvez ainda mais que na referência a Sigerist que inaugura seu curso sobre as ideologias médicas, que notamos a influência germano-americana sobre o trabalho de Canguilhem. Essas linhas retiradas das suas anotações de aula parecem-nos bastante esclarecedoras:

Qualquer que seja a forma histórica ou a distância de mediação entre o saber médico (ainda que suposto totalmente científico) e o ato terapêutico em um caso dado em um momento dado, é essa relação da prática ao saber, a um saber que não foi suscitado senão pela e para a prática, que constrange o pensamento médico a se mover no campo da ideologia. ${ }^{25}$

A maior parte do curso sobre as ideologias médicas do século XIX foi dedicada à história da terapêutica e, a propósito desse tema, nenhum historiador era mais relevante, naquele período, do que Erwin Ackerknecht. Jean-François Braunstein lembra que, muito antes de Foucault, a escola médica de Paris, "menosprezada pelos historiadores franceses da medicina", havia sido estudada "pelos historiadores anglo-saxões, mais sensíveis, desde Henry Sigerist, aos aspectos sociais da história da medicina" 26 . Na pasta com o material utilizado por Canguilhem em seu curso sobre as ideologias médicas no século XIX, preservada no CAPHÉS, encontramos diversos textos de Ackerknecht. De fato, todo o conteúdo sobre história da terapêutica (mais da metade do curso) foi ministrado por Canguilhem a partir desses textos. Para facilitar a discussão com seus alunos, Canguilhem até mesmo traduziu do alemão para o francês o texto "Die therapeustiche Erfahrung und ihre allmähliche Objektivierung" ("Conquête progressive de l'objectivité en expérimentation thérapeutique"), além de encarregar dois de seus alunos assistentes, Claude Debru e Evelyne Aziza-Shuster, respectivamente, da tradução dos artigos "Die Therapie im Fogefeuer während des 19. Jahrhunderts" ("Le purgatoire de la Thérapeutique au XIX ${ }^{\circ}$ siècle") e "Zellulartheorie und Therapie" ("Théorie cellulaire et Thérapeutique"). Esses textos foram publicados entre 1968 e 1969, portanto menos um ano antes do curso de Canguilhem, quando Ackerknecht já havia deixado os Estados Unidos e havia assumido a direção do Instituto de História da Medicina da Universidade de Zurique. Embora Canguilhem faça poucas referências a Ackerknecht em Ideologia e racionalidade na história das ciências da vida, a leitura dos manuscritos do curso e daquelas traduções permitem concluir que os artigos "Une

\footnotetext{
${ }^{25}$ CANGUILHEM, “L’idéologie médicale au XIX siècle”, manuscrito, f. 15-16.

${ }^{26}$ BRAUNSTEIN. "Daremberg et les débuts de l'histoire de la médecine en France", p. 387.
} 
idéologie médicale exemplaire: Le système de Brown”, texto de uma comunicação apresentada por Canguilhem em 1971 no XIII Congresso Internacional de História das Ciências, em Moscou, e "L'effet de la bactériologie dans la fin des 'théories médicales' au XIXe siècle", conferência apresentada em 1975 no Instituto de História da Medicina da Universidade Autônoma de Barcelona, desenvolvem temas tratados por Ackercknecht e rearticulados por Canguilhem a partir do problema das ideologias médicas.

Canguilhem centrou seu curso no século XIX por acreditar que, nesse momento, se instaurou uma nova situação da medicina na Europa a partir de três fenômenos: a constituição da fisiologia como disciplina médica autônoma, libertando-se da sua submissão à anatomia clássica (ideia que encontrou em Sigerist); o fato "ao mesmo tempo cultural e institucional" ao qual Foucault deu o nome de "nascimento da clínica"; e "a persistência e o desenvolvimento, tanto na Áustria quanto na França, de uma atitude pensada de ceticismo terapêutico, cujos trabalhos de Ackerknecht sublinharam o interesse" ${ }^{\text {27 }}$. Seguindo Ackerknecht, Canguilhem relacionou esse ceticismo terapêutico com o problema dos "sistemas médicos". Embora em desuso, a expressão “sistemas médicos" não chegou a ser abolida em nossos dias. Em 2006, o Ministério da Saúde lançou a Política Nacional de Práticas Integrativas e Complementares (PNPIC) do Sistema Único de Saúde, que apresentou a homeopatia da seguinte forma:

A Homeopatia, sistema médico complexo de caráter holístico, baseada no princípio vitalista e no uso da lei dos semelhantes enunciada por Hipócrates no século IV a.C., foi desenvolvida por Samuel Hahnemann no século XVIII. Após estudos e reflexões baseados na observação clínica e em experimentos realizados na época, Hahnemann sistematizou os princípios filosóficos e doutrinários da homeopatia em suas obras Organon da Arte de Curar e Doenças Crônicas. A partir daí, essa racionalidade médica experimentou grande expansão por várias regiões do mundo, estando hoje firmemente implantada em diversos países da Europa, das Américas e da Ásia. No Brasil, a Homeopatia foi introduzida por Benoit Mure em 1840, tornando-se uma nova opção de tratamento.

Da chegada de Mure ao Brasil, o texto do Ministério da Saúde avança até a fundação da Associação Médica Homeopática, em 1979, e o reconhecimento da homeopatia, no ano seguinte, como especialidade médica pelo Conselho Federal de Medicina. Somos informados que: em 1985, com o objetivo de institucionalizar a assistência homeopática na rede pública de saúde, foi firmado um convênio entre o Instituto Hahnemaniano do Brasil, o Instituto Nacional de Assistência Médica da Previdência Social (Inamps), a Fundação Oswaldo Cruz (Fiocruz) e a Universidade Estadual do Rio de Janeiro; em 1986, a 8 a Conferência Nacional de Saúde (CNS),

${ }^{27}$ CANGUILHEM, Idéologie et rationalité..., p. 58. 
impulsionada pela Reforma Sanitária, votou pela "introdução de práticas alternativas de assistência à saúde no âmbito dos serviços de saúde, possibilitando ao usuário o acesso democrático de escolher a terapêutica preferida"; em 1988, ano de fundação do Sistema Único de Saúde, a Comissão Interministerial de Planejamento e Coordenação (Ciplan) fixou normas para o atendimento em homeopatia nos serviços públicos de saúde; em 1990 foi criada a Associação Brasileira de Farmacêuticos Homeopatas e, em 1992, a homeopatia foi reconhecida como especialidade farmacêutica pelo Conselho Federal de Farmácia; em 1995, a $10^{\text {a }}$ Conferência Nacional de Saúde aprovou a "incorporação ao SUS, em todo o País, de práticas de saúde como a Fitoterapia, Acupuntura e Homeopatia, contemplando as terapias alternativas e práticas populares"; em 1999, o Ministério da Saúde inseriu a homeopatia na tabela do Sistema de Informações Ambulatoriais do SUS, permitindo o levantamento de dados oficiais que indicaram uma média de crescimento do número de consultas de $10 \%$ ao ano até o lançamento da PNPIC em 2006, quando ao menos dez universidades públicas desenvolviam atividades de ensino ou pesquisa em homeopatia (cursos de especialização eram oferecidos em doze estados), e a formação do Médico homeopata já havia sido aprovada pela Comissão Nacional de Residência Médica.

Essa narrativa, de impressionante linearidade, é a história oficial ${ }^{28}$ da vitória da homeopatia contra os obstáculos inicialmente impostos pela medicina alopática. É a história de resistência e glória de uma arte de cura em seu esforço de legitimação como opção terapêutica ao lado da medicina oficial, desafiando interpretações demasiadamente racionalistas sobre o processo de medicalização da sociedade no século XIX. Pode-se sempre objetar - e existem boas razões para isso - que a homeopatia, como arte de cura, já havia sido legitimada há muito tempo por uma parcela não-negligenciável da população ${ }^{29}$. Porém, como explicado pelo Ministério da Saúde, a homeopatia é um sistema médico complexo, com princípios filosóficos e doutrinários bem definidos, o que significa que, mais que curar, a homeopatia quer dizer a verdade sobre a cura, sobre a doença, sobre a saúde, sobre os remédios - daí a ênfase sobre o fato daqueles princípios terem sido "sistematizados" por Hahnemann no século XVIII após “estudos e reflexões baseados na observação clínica e em experimentos". O que essa história deixa de lado, no entanto, é toda a carga ideológica sintetizada na expressão "sistema médico".

\footnotetext{
${ }^{28}$ O plano de ação para a homeopatia na PNPIC foi elaborado por um grupo de trabalho composto pela Secretaria de Atenção à Saúde (Coordenação), Secretaria de Gestão no Trabalho e Educação na Saúde, Agência Nacional de Vigilância Sanitária (Anvisa), Secretaria de Ciência, Tecnologia e Insumos Estratégicos, Associação Médica Homeopática Brasileira (AMHB), Associação Brasileira de Farmacêuticos Homeopatas (ABFH) e Associação Brasileira de Cirurgiões Dentistas Homeopatas (ABCDH).

${ }^{29} \mathrm{Cf}$. o livro de Liane Maria Bertucci, "Influenza, a medicina enferma", que trata do recurso à homeopatia durante a epidemia de gripe espanhola em São Paulo em 1918.
} 
Segundo Jean-François Braunstein, os sistemas médicos são típicos da medicina do século XVIII, conheceram seu apogeu no século XIX, mas foram praticamente abandonados no século XX, muito em função da medicina experimental bernardiana. Eles foram desenvolvidos por grandes médicos, como Stahl, Hoffmann ou Boerhaave, e se caracterizam por apresentar um princípio único de explicação do ser vivo e por pretenderem também ser o único conhecimento verdadeiro do organismo e das práticas de cura $^{30}$. Ainda segundo Braunstein, esses sistemas médicos são largamente inspirados, por um lado, pelos sistemas filosóficos - como o mecanicismo cartesiano, mas também Galileu e Newton - e, por outro, pelo sucesso das ciências da época, notadamente a anatomia e a fisiologia. Em seu curso, Canguilhem explica que muitos desses sistemas médicos, e ele fala diretamente da homeopatia, são produtos de um momento do século XVIII conhecido como "crise da terapêutica", quando alguns médicos passaram a criticar a tradição livresca que predominava na medicina. Esses médicos passaram a notar que a maioria dos remédios empregados não produziam efeito sobre os doenças, e que, na verdade, muitos deles chegavam mesmo a produzir efeitos mais devastadores que a própria doença.

Ao adotar um princípio de explicação dos seres vivos, a expectativa era que a materia medica fosse administrada como parte de uma ação racional, cientificamente comprovada, para produção de determinado efeito sobre o organismo. Assim, por exemplo, Hahnemann, seduzido tanto pela "lei dos semelhantes" (similia similibus curantur), atribuída à escola hipocrática, quanto pelos ensaios empíricos conduzidos por William Cullen (de quem ele havia traduzido para o alemão livro A treatise on Materia Medica), conduz uma série de experimentos sobre o efeito de novas substâncias. Hahneman, que se dizia um empírico experimentalista, procurava criar artificialmente em indivíduos sadios (muitas vezes foi ele mesmo o sujeito dessas experiências) sintomas semelhantes aos de determinadas doenças. Alegando sucesso em diversos casos, formulou o princípio de similitude e constituiu uma opção terapêutica baseada no paralelo entre a sintomatologia clínica e a sintomatologia experimental. Embora o próprio Hahnemann inicialmente rejeitasse os sistema médicos, reivindicando um caráter revolucionário para seu princípio por conta de sua fundamentação experimental, a explicação para o princípio de similitude exigiu a adesão ao vitalismo, francamente inspirado pela obra de George Stahl. Assim, Hahnemann passa a preconizar a existência de uma energia vital imaterial cujos movimentos no organismo explicariam a origem das doenças e sobre os quais os medicamentos agiriam por dinamização dessa energia. Assim, para explicar em termos canguilhemianos, o princípio de similitude seria uma ideologia médica e a Homeopatia seria uma ideologia científica.

Ainda no curso de 1969-1970, encontramos uma ideia jamais exposta em qualquer

${ }^{30}$ BRAUNSTEIN, "Système médical”, p. 1110-111, passim. 
texto publicado. Segundo Canguilhem, a identidade entre o normal e o patológico deve ser entendida como uma ideologia médica porque "ela é um princípio suposto por suas consequências postas". Ele explica: "O projeto de Claude Bernard é um projeto científico quanto aos seus meios mas a finalidade desses meios é prática" ${ }^{\text {m1 }}$. Lembremos que, no Ensaio, Canguilhem argumenta que a identidade entre o normal e o patológico se tornou um dogma no século XIX através das contribuições decisivas de Auguste Comte e de Claude Bernard. Mas as intenções de um e de outro eram bem diferentes: em Comte, que foi buscar a ideia em Broussais, o interesse se dirige do patológico para o normal, diz Canguilhem, "com a finalidade de determinar especulativamente as leis do normal, pois é como substituto de uma experimentação biológica muitas vezes impraticável - sobretudo no homem - que a doença aparece digna de estudos sistemáticos”. Já em Claude Bernard, o interesse se dirige do normal para o patológico, “com a finalidade de ação racional sobre o patológico, pois é como fundamento de uma terapêutica em franca ruptura com o empirismo que o conhecimento da doença é procurado por meio da fisiologia e a partir dela" ${ }^{, 32}$.

Mais de vinte e cinco anos após a publicação da sua tese em medicina, Canguilhem retoma o problema da identidade entre o normal e o patológico em Claude Bernard, mas dessa vez para qualificá-lo enquanto ideologia médica, sem, no entanto, proceder a qualquer correção das ideias expostas no Ensaio. No texto de 1943, a identidade entre o normal e o patológico, que abolia a distinção entre fisiologia e patologia, era, para Claude Bernard, "a conclusão de uma vida inteira de experimentação biológica e cuja prática é codificada metodicamente”. Já no Curso sobre as ideologias médicas, a experimentação para Claude Bernard é descrita como "a fase preparatória e fria" da ação de uma medicina ativa, cujo objetivo era destronar a medicina contemplativa, de observação, assentada sobre um otimismo em relação à natureza ${ }^{33}$. Ao fundamentar na opção terapêutica o êxito do conhecimento fisiológico, a medicina experimental de Claude Bernard se consolidava, nas palavras de José Ricardo Ayres, como "o primeiro grande paradigma das ciências da saúde em seus traços modernos" ${ }^{\text {,34 }}$. Um paradigma assentado sobre uma ideologia médica, o princípio, ou "dogma”, da identidade entre o normal e o patológico, que, por sua conformação científica na fisiologia, "fundou uma ideologia, a ideologia do poder ilimitado da medicina" 35 .

\footnotetext{
${ }^{31}$ CANGUILHEM, "L’idéologie médicale au XIX siècle", f. 46.

${ }^{32}$ Idem.

${ }^{33}$ CANGUILHEM, "L'idéologie médicale au XIX siècle", manuscrito, f. 15-16.

${ }^{34}$ AYRES, Epidemiologia e emancipação, p. 100.

${ }^{35}$ CANGUILHEM, Le normal et le pathologique, p. 40.
} 


\section{A vida e as normas}

No curso de 1942-1943 sobre as normas e o normal ministrado na Faculdade de Letras de Estrasburgo ("As normas e o normal" era, na verdade, o tema elaborado por Canguilhem naquele ano para o "Curso de Filosofia Geral e de Lógica"), encontramos a ideia de que o estado patológico não deve ser entendido como ausência de normas, pois "o normal é uma categoria universal da vida"36. Assim, para Canguilhem, desse ponto de vista biológico, o patológico também é normal, quer dizer, ele diz respeito às normas biológicas estabelecidas pela vida para se tornar viável em determinado meio. No entanto, esse normal será patológico no momento em que, nessa relação entre o ser vivo e seu meio, qualquer variação em um ou outro desses termos comprometa irreparavelmente a vida ${ }^{37}$. Assim, em vez de opor normal e patológico, o que Canguilhem propõe, a título de axioma, é que se oponha saúde e doença, pois saúde é mais que normal - de um ponto de vista biológico, estatístico ou psíquico: saúde é normatividade, isto é, a capacidade do indivíduo de criar outras normas, a capacidade do indivíduo se permanecer normativo diante das inconstâncias do meio.

É a relação do meio e do ser vivo que faz com que um e outro sejam normais. Um ser vivo é normal, no sentido autêntico, a partir do momento em que ele traduz um esforço da vida para se manter nas formas e nas normas que admitem uma margem de variação, uma atitude de dissidência tal que, venham as condições do meio a varia, qualquer uma dessas formas poderá se revelar vantajosa, logo, mais viável. Um meio é normal a partir do momento em que ele permite a uma espécie aí se multiplicar e se diversifica, de modo a tolerar, em caso de necessidade, as infidelidades do meio. ${ }^{38}$

Num texto publicado mais de três décadas depois, intitulado "Une pédagogie de la guérison est-elle possible?", Canguilhem faz a crítica de uma particularmente cara ao pensamento médico - ainda que, curiosamente, pouco presente na literatura médica -, a ideia de "cura". Canguilhem explica que o sentido etimológico da palavra é "proteger, defender, municiar, quase militarmente, contra uma agressão ou sedição", razão pela qual se difundiu, no pensamento médico, a ideia de doença como "luta", válida tanto para a concepção ontológica de doença (luta contra um agente invasor) quanto para a concepção dinâmica (luta entre as forças internas do organismo). O mais importante é que a partir desses elementos do pensamento médico foram elaborados certos tipos de prática médica que influíram sobre a expectativa do médico e doente

\footnotetext{
${ }^{36}$ CANGUILHEM, "Cours de philosophie générale et logique", p.104.

${ }^{37}$ Ibidem, p. 107.

${ }^{38}$ Ibidem, p.106.
} 
em torno da ideia de cura como restabelecimento a um estado anterior. Já naquele curso de 19421943 Canguilhem havia feito a crítica dessa ideia a partir do que tem sido chamado de seu "vitalismo dinâmico":

Um doente é um homem que faz um esforço para instaurar uma nova ordem, uma nova estabilidade em seu debate com o meio. E se ele se cura, haverá retorno a uma norma, mas não à antiga. A norma nova não é jamais idêntica à antiga. Mas, durante o curso da doença, o comportamento do doente é dirigido pela ansiedade de escapar das reações catastróficas. Uma reação catastrófica traduz a impossibilidade para o doente de se adaptar rapidamente às novas condições do meio. Essa preocupação de evitar as reações catastróficas traduz, então, a tendência à conservação do organismo. A conservação de si não é a tendência mais geral da vida, é a tendência característica de uma vida diminuída, apequenada. O homem são é capaz de encarar os riscos, e sua produtividade sua normatividade - se traduz pela sua capacidade de suportar as catástrofes para chegar a uma nova ordem. ${ }^{39}$

Essas lições fazem parte da tese de "filosofia médica" que Canguilhem defendeu em 1943 junto à Faculdade de Medicina de Estrasburgo. Embora houvesse dito não pretender dar lições aos médicos, no Ensaio, Canguilhem propõe algumas "proposições de método e de doutrinas" resumidas da seguinte maneira:

1) "Normatividade biológica" é a capacidade da vida de estabelecer valores, não apenas no meio, mas também no organismo;

2) O patológico também é normal, mas não pode ser considerado qualitativamente idêntico ao normal fisiológico;

3) O "homem são" é o homem normativo em diante das inconstâncias do meio; o patológico expressa a precariedade da capacidade normativa estabelecida pela doença;

4) A normatividade biológica é irreversível: curar é criar novas normas, não retornar às normas antigas;

5) O normal, posto que diz respeito a uma normatividade orgânica em relação ao meio, não é um conceito objetivamente determinável por métodos científicos. A fisiologia não é a ciência do normal, mas das "situações e condições biológicas consideradas normais";

6) A atribuição de um valor de "normal" àquelas situações e condições biológicas reflete, por um lado, a relação das ciências da vida com a normatividade da vida e,

${ }^{39}$ Idem. 
por outro, das ciências da vida com as técnicas de produção e instauração do normal (a medicina);

7) A medicina existe porque existem homens que se sentem doentes. Como técnica, ela traduz um esforço espontâneo de organização e dominação do meio pelo ser vivo. É também por isso que ela busca os resultados das ciências da vida;

8) "Qualquer conceito empírico de doença conserva uma relação com o conceito axiológico da doença. Não é, portanto, um método objetivo que qualifica como patológico um determinado fenômeno biológico. É sempre a relação com o indivíduo doente, por intermédio da clínica, que justifica a qualificação de patológico. Embora admitindo a importância dos métodos objetivos de observação e de análise na patologia, não parece possível que se possa - com absoluta correção lógica - falar em "patologia objetiva". É claro que a patologia pode ser metódica, crítica, armada de meios experimentais. Essa patologia pode ser considerada objetiva, em relação ao médico que a pratica. Mas a intenção do patologista não faz com que seu objeto seja uma matéria desprovida de subjetividade. Pode-se praticar objetivamente, isto é, imparcialmente, uma pesquisa cujo objeto não pode ser concebido e construído sem referência a uma qualificação positiva e negativa; cujo objeto, portanto, não é tanto um fato mas, sobretudo, um valor." 40

Canguilhem não era afeito ao trabalho de revisão nas reedições de seus textos, mas nunca deixou de reformular seu pensamento diante das críticas e debates inaugurados a cada nova publicação, cujo local de nascimento eram seus cursos universitários. Mas, após a reforma de pensamento, em vez de condenar ou reescrever seus trabalhos, Canguilhem esforçava-se para preservar o que neles havia de atual. "Há algo melhor a fazer do que salpicar de reparos ou enriquecimentos um antigo texto. É tratar como nova a mesma questão", afirmou no prefácio à segunda edição de $O$ conhecimento da vida. A preocupação com o problema das relações entre as normas e o normal, por exemplo, foi constante na obra de Canguilhem.

Em 1966, Canguilhem lançou o livro O normal e o patológico, como já dissemos, a reunião de dois textos: o Ensaio sobre alguns problemas relativos ao normal e ao patológico, tese de doutorado em medicina defendida em 1943, e um texto inédito, intitulado Novas reflexões referentes ao normal e ao patológico, escrito entre 1963 e 1966, quando Canguilhem já ocupava a presidência do Institut d'Histoire et Philosophie des Sciences et des Techniques e dava aulas na

${ }^{40}$ CANGUILHEM, Le normal et le pathologique, p. 92-93. 
Sorbonne. Dois textos, escritos num intervalo de cerca de vinte anos, abordando o mesmo problema. "Ao acrescentar algumas considerações inéditas ao meu primeiro Ensaio", escreveu Canguilhem na primeira edição do novo livro, "busco apenas fornecer um testemunho dos meus esforços, se não do meu sucesso, para conservar um problema, que eu considero fundamental, no mesmo estado de frescor que seus dados de fato, sempre em transformação”. Na abertura das Novas reflexões, Canguilhem falou sobre a origem dos textos:

Em 1943, professor da Faculdade de Letras de Estrasburgo, em ClermontFerrand, dei um curso sobre As normas e o normal [Les normes et le normal], ao mesmo tempo que redigia minha Tese de Doutorado em Medicina, defendida em julho do mesmo ano, na Faculdade de Medicina de Estrasburgo. Em 1963, como professor da Faculdade de Letras e Ciências Humanas de Paris, dei um curso sobre o mesmo tema. Quis, 20 anos depois, me defrontar com as mesmas dificuldades, com outros meios. ${ }^{41}$

Entre esses novos meios ou dados de que dispunha o filósofo em 1963, Canguilhem menciona um texto de 1798, no qual Kant já dizia que "foram as doenças que deram origem à fisiologia; e não foi a fisiologia, e sim a patologia e a clínica que deram origem à medicina". Canguilhem segue citando Kant: "a razão é que, para dizer a verdade, não sentimos o bem-estar, pois este bem-estar é simples consciências de viver, e só seu impedimento suscita a força de resistência". Segundo Canguilhem, a descoberta de um texto como esse causava uma dupla sensação: a da satisfação por um achado feliz e o embaraço com a própria ignorância, que o levou a pretender certa originalidade em sua tese. Afinal, na conclusão da sua tese, Canguilhem afirma que "existe medicina, em primeiro lugar, porque os homens se sentem doentes. É apenas em segundo lugar que os homens, pelo fato de existir uma medicina, sabem em que consiste sua doença" ${ }^{42}$.

Além do texto de Kant, Canguilhem também afirma que novas leituras de Claude Bernard, permitidas pela publicação, naquele intervalo, dos Principes de médecine expérimentale, atenuaram as críticas que havia feito à ideia de Claude Bernard a respeito das relações entre fisiologia e patologia. Canguilhem via, agora, que Claude Bernard também entendia a precedência da experiência clínica sobre a experimentação de laboratório: "Se estivesse lidando com principiantes, eu lhes diria, em primeiro lugar, para irem ao hospital; é a primeira coisa a conhecer. Pois como analisaríamos, por meio da experimentação, doenças que não conhecemos?”, escreveu Claude Bernard em Principes de médecine expérimentale. Buscando devolver a Claude Bernard algo que havia lhe tirado, Canguilhem cita: "Vão primeiro ao hospital;

\footnotetext{
${ }^{41}$ CANGUILHEM, Le normal et le pathologique.

${ }^{42}$ Ibidem, p. 94.
} 
no entanto, isso não é suficiente para chegar à medicina científica ou experimental; é preciso, em seguida, ir ao laboratório para analisar experimentalmente aquilo que a observação clínica nos fez constatar".

Mas, diz Canguilhem, o tema dos dois cursos, e o que fez reeditar sua tese ao lado dessas novas reflexões, é algo que vai além desse problema de filosofia médica:

O sentido dos conceitos de norma e de normal nas ciências humanas, em sociologia, em etnologia, em economia, leva a pesquisas que, quer se trate de tipos sociais, de critérios de inadaptação ou grupo, das necessidades e dos comportamentos de consumo, ou dos sistemas de preferência, se orientam, em última análise, para o problema das relações entre normalidade e generalidade. Se, de início, vou buscar alguns elementos de análise nas lições em que examinei, à minha maneira, alguns aspectos dessa questão, é unicamente para esclarecer, por meio da confrontação das normas sociais e das normas vitais, a significação específica destas últimas. É apenas tendo em vista o organismo que permito a mim mesmo algumas incursões no estudo da sociedade. ${ }^{43}$

Essa incursão no estudo da sociedade feita por Canguilhem pode ser explicada por meio do conceito de "normalização", um "conceito polêmico", admite. "Normalizar é impor uma exigência a uma existência, a um dado, cuja variedade e disparidade se apresentam, em relação à exigência, como um indeterminado hostil, mais ainda que estranho", definiu. Segundo Canguilhem, a "a experiência de normalização é uma experiência especificamente antropológica ou cultural", isso porque ela pressupõe o conceito de "norma" como a "expressão de uma preferência" e como "instrumento de uma vontade", quer dizer, ela compara o real a valores e qualifica negativamente aquilo que não cabe em sua extensão ${ }^{44}$. Por sua vez, o normal passa a ser definido como "o efeito obtido pela execução do projeto normativo, é a norma manifestada no fato" ${ }^{45}$. Canguilhem segue explicando que uma norma não atua sozinha, que ela pressupõe outras normas, o que existe é uma "correlatividade de normas sociais" que tende a fazer de sua unidade virtual uma organização.

Quando se trata de normas humanas, esse estudo reconhece que essas normas são determinadas como possibilidade de agir de um organismo em situação social, e não como funções de um organismo encarado como mecanismo vinculado ao meio físico. A forma e as funções do corpo humano não são apenas a expressão de condições impostas à vida pelo meio, mas a expressão dos modos de viver socialmente adotados no meio. ${ }^{46}$ ]

\footnotetext{
${ }^{43}$ CANGUILHEM, Le normal et le pathologique, p. 190.

${ }^{44}$ Idem.

${ }^{45}$ Ibidem, p.192.

${ }^{46}$ Ibidem, p. 124.
} 
Assim, a "experiência de normalização" faz parte do que poderia ser chamado de uma homeóstase social, a tentativa de regulação de uma organização social ou a busca do sentido de uma produção, semelhante ao organismo vivo. No entanto, enquanto a meta de um organismo é um outro organismo sadio da mesma espécie, as sociedades, pela falta de consenso quanto a um modelo ideal, só podem atingir o equilíbrio a partir da intervenção sobre os elementos considerados de risco ao conjunto da população: “a definição de normas higiênicas supõe o interesse que se dá - do ponto de vista político - à saúde das populações considerada estatisticamente, à salubridade das condições de vida, à extensão uniforme dos tratamentos preventivos e curativos elaborados pela medicina" 47 .

Nessa passagem das normas vitais às normas sociais nos dois textos de Canguilhem sobre o normal e o patológico, o que muda é a própria relação do ser vivo com o meio e, ato contínuo, a própria forma de atribuição de valor à vida, não mais por meio de uma normatividade biológica individual, mas como parte de um programa social.

\section{A normalização e o conceito de biopoder em Michel Foucault}

Hoje, a principal tarefa assumida pelos comentadores de Canguilhem consiste em relacionar aquilo que foi durante muito tempo chamado sua "obra" com os textos inéditos, com os manuscritos e, sobretudo, com os cursos encontrados após a abertura dos seus arquivos. De modo semelhante, há mais de uma década os comentadores de Foucault tem buscado conciliar os cursos ministrados no Collége de France e os livros publicados. O biopoder, conceito fundamentado sobre o binômio norma-vida, encontra sua elaboração final nos cursos ministrados no período de oito anos que separa o primeiro e o segundo volume da História da sexualidade. Nas próximas páginas, teceremos algumas considerações sobre esse conceito a partir dos cursos ministrados entre 1973 e $1979^{48}$. Pretendemos com isso mostrar como a moldura da análise de Foucault sobre o biopoder é determinada pelo processo histórico conceitualmente definido por Canguilhem como "normalização".

O biopoder aparece como problema a partir de Os anormais, contudo, em seu curso

\footnotetext{
${ }^{47}$ CANGUILHEM, loc. Cit.

${ }^{48}$ O poder psiquiátrico (1973-1974), Os anormais (1974-1975), Em defesa da sociedade (1975-1976), Segurança, território, população (1977-1978) e Nascimento da biopolítica (1978-1979). Segurança, território, população e Nascimento da biopolítica, apesar de dedicados ao biopoder, não marcam o início da relação entre poder e vida no interior do pensamento foucaultiano: Os anormais já permite esse diagnóstico e, no curso Em defesa da sociedade, o conceito de biopoder já apresenta a formulação que aparecerá nos cursos posteriores e no capítulo final de História da sexualidade I: A vontade de saber.
} 
anterior, $O$ poder psiquiátrico, ocorre uma virada fundamental nas pesquisas de Foucault: a mudança no foco de interesse das questões epistemológicas acerca do estatuto científico da psiquiatria e da violência com que atravessava os indivíduos para os mecanismos de funcionamento do poder psiquiátrico que operavam a partir das grandes tecnologias de poder. Ao realizá-la, Foucault abandona o tratamento da loucura como experiência fundamental que lhe permitia construir uma história da racionalização ocidental como história da destituição dos antigos poderes da loucura, imprimindo-lhe um sentido trágico, mas também uma leitura bastante peculiar de Nietzsche, certamente influenciada por Georges Bataille, que consistia em opor verdade e poder. ${ }^{49}$

Ao compreender o poder a partir de uma teoria da ideologia, ou seja, o poder como instrumento essencialmente negativo de repressão e velamento da realidade, Foucault não estava muito distante de alguns dos seus contemporâneos. Essa "hipótese repressiva" encontra-se formulada tanto na teoria althusseriana dos aparelhos ideológicos do Estado, como na perspectiva jurídico-discursiva do poder sustentada por Marcuse. ${ }^{50}$ Nesse momento entra em jogo aquilo que Foucault chamou de "benefício do locutor": se a tática do poder é o mutismo, um discurso humanista qualquer que simplesmente falasse sobre o sexo já representaria, por si só, um ato de transgressão, daí toda a pompa e solenidade com que tratamos a sexualidade ainda hoje. Trata-se, segundo Foucault, da mais efetiva tática do poder, a capacidade de mascarar os seus mecanismos, fazendo com que aqueles que se dizem opostos a ele discutam, por exemplo, a interpretação de uma lei, ao invés do sistema jurídico-discursivo. Quando se pensa que verdade e poder não se opõem, quando se leva em conta a positividade do poder, sua capacidade de criar verdades, o "benefício do locutor", de oposto do poder passa a ser entendido como uma das suas estratégias de desenvolvimento 51 .

A partir de $O$ poder psiquiátrico, Foucault voltará sua atenção para os efeitos de saber e as técnicas de sujeição que são produzidos pelas táticas de poder, daí o interesse pelos agenciamentos concretos que fazem parte das diversas relações de produção (familiar, sexual, etc.). Foucault não se permitirá fazer uma história da sexualidade como mero apêndice da história do capitalismo. Ao contrário, vai chamar a atenção para o efeito circular do poder, entendido agora como uma série de mecanismos que tem por objetivo garantir a sua própria manutenção.

\footnotetext{
${ }^{49}$ MACHADO, Foucault, a filosofia e a literatura, p. 23-28. Cf. FOUCAULT, História da loucura, p. 29: “A bela retidão que conduz o pensamento racional à análise da loucura como doença mental deve ser reinterpretada numa dimensão vertical; e neste caso verifica-se que sob cada uma de suas formas ela oculta de uma maneira mais completa e também mais perigosa essa experiência trágica que tal retidão não conseguiu reduzir."

${ }^{50}$ FOUCAULT, Sécurité, territoire, population, p. 07.

${ }^{51}$ DREYFUS e RABINOW, Michel Foucault, beyond structuralism and hermeneutics, p. 130.
} 
Quando destaca o caráter essencialmente operatório do poder, Foucault acredita estar formando indicadores táticos e esclarecendo os campos de batalha do seu agir filosófico. ${ }^{52}$

O biopoder é um conceito essencial para a compreensão do ethos filosófico foucauldiano, pois traduz a tomada de consciência da vida pelo poder. O desenvolvimento do capitalismo só foi possível graças à "inserção controlada dos corpos no aparelho de reprodução e por meio de um ajustamento dos fenômenos de população aos processos econômicos". ${ }^{3}$ Aí Foucault identifica duas estratégias: de um lado a anátomo-política do corpo através das técnicas disciplinares e, de outro, a regulação das multiplicidades através de uma política biológica da população. Não se trata mais do estudo das teorias políticas do poder, mas das tecnologias, técnicas e mecanismos pelos quais ele se exerce; tanto os que são próprios do controle social, como aqueles que têm por função modificar o destino biológico da espécie. Daí o interesse por uma técnica que é justamente a confluência de diversas ciências que têm o homem-vivo por objeto, a medicina, e aquele que foi o espaço privilegiado de conhecimento e também de intervenção sobre esse objeto, o hospital. Vale a pena transcrever os dois primeiros parágrafos de uma nota que Canguilhem publicou no jornal francês Le Monde a propósito das pesquisas de Foucault sobre a medicina e o hospital, especificamente o livro coletivo Les Machines à guérir:

A transformação iniciada no século XVIII que dissociou, na destinação das instituições de "beneficência", a assistência aos coitados e o cuidado dos doentes é um fato de política cuja realidade é atestada pela própria arquitetura dos prédios hospitalares e a distribuição do espaço interno onde os cuidadores dispõem, expõem e tratam os doentes, em conformação com um regulamento explícito. A saúde, visada a partir de então como o bem geral de determinada população, e não mais apenas como um valor individual, não depende mais unicamente da arte de um homem de experiência, mas dos cálculos de uma administração que reivindica a sua gestão como um dever.

Isso que Michel Foucault chama de noso-política compõe, em relação ao corpo social, os imperativos do rendimento e da vigilância, da economia e da polícia. Seu objeto é tributário da medida e da apreciação demográfica. A mudança de escala do objetivo médico encadeia uma mudança da natureza dos meios. O hospital não é a possibilidade oferecida aos médicos de multiplicar os atos terapêuticos personalizados. Como escreveu Tenon, em 1788, "os hospitais são ferramentas, ou, se preferirmos, máquinas de tratar os doentes, em massa e por

\footnotetext{
52 "L'impératif, par conséquent, qui soustend l'analyse théorique qu'on est en train d'essayer de faire - puisqu'il faut bien qu'il y en ait un -, je voudrais qu'il soit simplemente un impératif conditionnel du genre de celui-ci: si vous voulez lutter, voiciu quelques points clés, voici quelques lignes de force, voici quelques verrous et quelques blocages. Autrement dit, je voudrais que ces impératifs ne soient rien d'autres que des indicateurs tactiques. À moi de savoir, bien sûr, et à ceux qui travaillent dans le même sens, à nous par conséquent de savoir sur quels champs de forces réelles on se repére pour faire une analyse qui serait efficace en termes tactiques. Mais, après tout, c'est là le cercle de la lutte et de la vérité, c'est-à-dire justement de la pratique philosophique". In: FOUCAULT, Sécurité, territoire, population, p. 09.

${ }^{53}$ FOUCAULT, Em defesa da sociedade, p. 288.
} 
economia, eu diria de bom grado".

(...) Ele [o livro Les Machines à guérir] se inscreve no projeto, realizado progressivamente por Michel Foucault, de desenhar as múltiplas faces do poder nas sociedades contemporâneas, poder de definição e de disciplina dos valores sociais da vida, poder de "normalização" dos erros e dos desvios, doença, loucura, delinquência. Vigiar e punir. Vigiar e reformar. Vigiar e curar.

As sociedades disciplinares seriam, portanto, simultaneamente massificantes e individuantes. De fato, é engano acreditar que o indivíduo é o alvo principal ou o ponto de partida das disciplinas. Conforme Foucault, não existe disciplina se não houver um fim a ser obtido das multiplicidades. O indivíduo é apenas o modo como as disciplinas atravessam essas multiplicidades para melhor organizá-las ${ }^{54}$. A necessidade desse tipo de intervenção é fruto do desenvolvimento do capitalismo. Quando as técnicas de confisco (do trabalho, do tempo, etc.) da soberania tornaram-se empecilho ao desenvolvimento das forças produtivas, foi necessária a inserção das multiplicidades nos aparelhos de reprodução através de esquemas de vigilância, treinamento e punição dos corpos individuais. Após esse trabalho de sujeição dos corpos, seguiuse a ampliação das forças através de uma série de dispositivos que vão focar o homem na sua condição de ser vivo graças à produção de dados estatísticos e de um conjunto de saberes referentes a processos globais biológicos como nascimento, mortalidade e fecundidade.

Se nos séculos XV, XVI e XVII o confinamento do Outro no hospital não estava diretamente ligado a uma expertise médica, mas ao poder de exclusão de "tudo o que o próprio homem pôde inventar como irregularidades de conduta" ${ }^{55}$, nessa nova sociedade que começa a se organizar no século XVIII, e que ainda nos serve, a medicina passa a ter a "função maior da higiene pública, com organismos de coordenação dos tratamentos médicos, de centralização da informação, de normalização do saber, e adquire também o aspecto de campanha de aprendizado da higiene e de medicalização da população" 56 : uma série de medidas profiláticas que, ao contrário da exclusão ou das internações vigiadas, tem por objetivo manter o maior número possível de pessoas longe dos hospitais.

Evidentemente, uma mudança de tal amplitude não foi operada a partir da medicina, mas Foucault também se recusou a traduzir no discurso médico as condições pré-discursivas do século XVIII. Conforme Frédéric Gros, foi como alternativa a tais explicações marxistas, como alternativa às explicações não-integradas, que Foucault fez entrar em jogo um novo elemento: as

\footnotetext{
54 "La discipline est une mode d'invidualisation des multiplicités et non pas quelque chose qui, à partir des individus travaillés d'abord à titre individuel, construirait ensuite une sorte d'edifice à éléments multiples". FOUCAULT, Sécurité, territoire, population, p. 14.

${ }^{55}$ FOUCAULT, História da loucura, p. 25.

${ }^{56}$ FOUCAULT, Em defesa da sociedade, p. 291.
} 
normas $^{57}$. A referência a Canguilhem nesse ponto é explícita. Em Os anormais Foucault deixou evidente que seu objetivo seria aplicar historicamente o conceito de normalização apresentado por Canguilhem na segunda edição de seu $O$ normal e o patológico, de onde afirma ter retirado também um conjunto de ideias histórica e metodologicamente fecundas sobre o poder. ${ }^{58}$

A primeira dessas ideias encontradas em Canguilhem diz respeito ao que seria um processo geral de normalização social, política e técnica que estaria em curso no século XVIII e que se manifestaria nos locais frequentemente associados ao poder disciplinar, isto é, a escola, o hospital, a indústria, o exército, etc. Segundo, a ideia de que uma norma se define pelo papel de exigência e de coerção que ela exerce, daí Foucault ter dito que a norma é o elemento que funda e legitima um exercício de poder. A terceira e mais importante ideia é o princípio de qualificação presente em toda norma. De acordo com Canguilhem, "depreciando tudo aquilo que a referência a ela própria impede de considerar normal, a norma cria, por si mesma, a possibilidade de uma inversão dos termos" ${ }^{59}$. A norma, portanto, não exclui somente, ela está sempre ligada a técnicas positivas de intervenção e transformação que exigem, como condição de exercício, a formação de um saber.

O que o século XVIII instaurou mediante o sistema de "disciplina para a normalização", mediante o sistema "disciplina-normalização", parece-me ser um poder que, na verdade, não é repressivo, mas produtivo - a repressão só figura a título de efeito colateral e secundário, em relação a mecanismos que, por sua vez, são centrais relativamente a esse poder, mecanismos que fabricam, mecanismos que criam, mecanismos que produzem $^{60}$.

É possível descrever a obra de Canguilhem como um esforço de valorização do vitalismo, tarefa que exigiu a limpeza de toda carga metafísica que a história de medicina sedimentou sobre essa teoria. Canguilhem definiu o vitalismo de forma bastante simples, como o reconhecimento da originalidade do fato vital. Entretanto, foi de encontro a um tipo de pensamento dominante, filiado historicamente a Claude Bernard, que negava tal originalidade e fazia do princípio de inércia - representado em matéria de saúde pela média do desempenho orgânico de uma população - o elemento normatizador da medicina. ${ }^{61}$ Nas Novas reflexões sobre o normal e o patológico, texto que Foucault tinha em mente durante seus cursos, Canguilhem buscou mais apreender o sujeito social como um prolongamento do indivíduo biológico, mas

\footnotetext{
${ }^{57}$ GROS, Foucault et la folie, p. 82.

${ }^{58}$ FOUCAULT, Os anormais, p. 61-65.

${ }^{59}$ CANGUILHEM, Le normal et le pathologique, p. 212.

${ }^{60}$ FOUCAULT, op. cit., p. 64.

${ }^{61}$ CANGUILHEM, Le normal et le pathologique, p. 156.
} 
compreender como a normalização social estabelece novas formas de normatividade vital: "a norma", sentencia Canguilhem, "é aquilo que fixa o normal a partir de uma decisão normativa"62.

Cabe a pergunta: em que consistia o grande projeto de normalização que engendrou os séculos XVIII e XIX e escolheu a vida biológica como alvo de suas investidas? Ainda que esteja mais interessado nos mecanismos de funcionamento do poder que nas teorias políticas que o justificavam, Foucault nos lembra que foi primeiro nesse âmbito que a vida se tornou um problema. A soberania, especialmente quando assentada sobre teorias contratualistas de tipo hobbesiano, detinha um poder dito "de vida e de morte", mas que na verdade era unilateral, pois o que se entendia por poder sobre a vida era, de fato, o poder de permitir que um súdito continuasse a viver. Era, portanto, sobre a morte que agia efetivamente esse poder soberano. $\mathrm{O}$ que se começou a questionar foi como uma soberania fundada sobre a vida - pois foi o medo de perdê-la que levou os homens a ceder parte de sua liberdade individual natural e firmar um pacto poderia dispor da vida dos seus súditos. A vida, enquanto fundadora da sociedade, não deveria estar fora do alcance do soberano? A grande mudança ocorrida no direito político no século XIX foi, segundo Foucault, não o abandono dessa velha compreensão do direito soberano, mas o surgimento de um outro direito que vai atravessá-lo e complementá-lo: o direito de fazer morrer e deixar viver será modificado por um tipo de poder que é exatamente o seu inverso, isto é, o direito de fazer viver e de deixar morrer. ${ }^{63}$

As sociedades de soberania, incapazes de suportar as pressões econômicas ocasionadas pelo crescimento demográfico e a industrialização, tendo investido inicialmente sobre os corpos individuais, cederam lugar às sociedades disciplinares, e, em seguida, ao voltarse, não mais para as mortes ou nascimentos, mas para as taxas de mortalidade e fecundidade, enfim, aos processos bio-sociológicos da espécie humana, deram lugar, na passagem do século XVIII para o XIX, ao que Foucault chamou de sociedades de normalização. Não mais das epidemias, da morte que se abate sobre a vida, tratar-se-á das “doenças reinantes”, das endemias, encaradas como "fatores permanentes (...) de subtração das forças, diminuição do tempo de trabalho, baixa de energias, custos econômicos, tanto por causa da produção não realizada quanto dos tratamentos que podem custar" ${ }^{64}$. Em relação ao onanismo infantil no século XVIII, por exemplo, Foucault encontrou nos discursos e práticas médicas a ideia de uma doença total, "uma espécie de doença polimorfa, absoluta, sem remissão, que culminaria em si todos os sintomas de todas as doenças possíveis (...). Todos os sintomas da doença vêm se superpor no corpo descarnado e devastado do jovem masturbador", mas encontramos também uma cruzada anti-

\footnotetext{
${ }^{62}$ CANGUILHEM, Le normal et le pathologique, p. 218.

${ }^{63}$ FOUCAULT, Em defesa da sociedade, p. 286-289.

${ }^{64}$ Ibid, p. 290.
} 
masturbatória, levada a cabo pela escola e, principalmente, pela família do jovem onanista ${ }^{65}$. Mecanismos de normalização da vida, sem dúvida, mas empreendidas a partir das técnicas disciplinares do corpo.

Entende-se agora porque a medicina ocupa espaço privilegiado nessas sociedades. Portadora das normas biológicas, capaz de atravessar tanto o espaço disciplinar como gerir processos de regulamentação, presente desde os discursos sobre os efeitos colaterais da masturbação sobre o corpo da criança no século XVIII até o racismo do Estado nazista, a medicina vai contribuir para a normalização social a partir da normatização vital das populações:

De uma forma mais geral ainda, pode-se dizer que o elemento que vai circular entre o disciplinar e o regulamentador, que vai se aplicar, da mesma forma, ao corpo e à população, que permite a um só tempo controlar a ordem disciplinar do corpo e os agenciamentos aleatórios de uma multiplicidade biológica, esse elemento que circula entre um e outro é a 'norma'. A norma é o que pode tanto se aplicar a um corpo que se quer disciplinar quanto a uma população que se quer regulamentar. A sociedade de normalização não é, pois, nessas condições, uma espécie de sociedade disciplinar generalizada cujas instituições disciplinares teriam se alastrado e recoberto todo o espaço - essa não é, acho eu, senão uma primeira interpretação, e insuficiente, da ideia de sociedade de normalização. A sociedade de normalização é uma sociedade em que se cruzam, conforme uma articulação ortogonal, a norma da disciplina e a norma da regulamentação. ${ }^{66}$

O que caracteriza um "estilo francês de história da medicina" é justamente essa dupla exigência de uma investigação sobre o poder de definição dos valores sociais da vida e sobre a função da medicina na experiência de normalização dos seres vivos, ao mesmo tempo em que se faz a crítica epistemológica dos meios técnicos e científicos por ela elaborados para o cumprimento dessa função.

\section{Consideração sobre a historiografia brasileira da medicina}

Não é nosso objetivo escrever uma história da recepção da teoria da história de Canguilhem no Brasil. A questão é sem dúvida importante, especialmente se considerarmos a relevância, desde os anos 70, e ainda hoje, de $O$ normal e o patológico para os debates epistemológicos sobre a saúde no Brasil. Mas o tratamento adequado do tema merece uma

\footnotetext{
${ }^{65}$ FOUCAULT, Os anormais, p. 301-305.

${ }^{66}$ Ibidem, p. 302.
} 
pesquisa independente, com questões diferentes das que apresentamos. Queremos apenas mostrar certos aspectos dessa recepção, no que diz respeito ao problema da história na obra de Canguilhem, para reforçar essa ideia de um "estilo francês" de história da medicina.

A compreensão de que a historicidade dos conceitos de saúde e doença e das relações que mantêm entre si influi diretamente sobre a prática médica está longe de ser uma novidade para os historiadores brasileiros - pelo menos desde a recepção, entre nós, das obras Georges Canguilhem e de Michel Foucault. Um fato já solidificado em nossa historiografia, diz que tem sido assim no Brasil desde a década de 70, como atestariam os livros Danação da norma (1978), de Roberto Machado (et al.), e Ordem médica e norma familiar (1979), de Jurandir Freire Costa. As primeiras palavras de apresentação do livro de Roberto Machado são esclarecedoras: "Estudo de história dos saberes, este livro tem por objetivo dar conta do nascimento de um tipo de medicina característico da sociedade capitalista". Ele segue explicando: "[este livro] analisa os conceitos básicos da medicina social e da psiquiatria brasileiras; mas não se limita a uma abordagem interna: pretende refletir sobre esses saberes como prática social". ${ }^{67}$

Num livro bem mais recente, Práticas médicas e de saúde nos municípios paulistas, nós encontramos uma boa indicação sobre os caminhos da historiografia da medicina no Brasil: após afirmarem, na introdução à obra coletiva, o interesse crescente dos historiadores profissionais pela história das ciências, os autores, Antonio Celso Ferreira e Tania Regina de Luca, avaliam que também é crescente "a contribuição da história (e das ciências humanas em geral) à medicina desde a abordagem pioneira de Michel Foucault, sobretudo, em $O$ nascimento da clínica". A maior contribuição da história para a medicina, eles deixam claro, é a sua função crítica, ou seja, a "possibilidade de investigar os modos próprios de constituição dos saberes no que tange a vários aspectos: seus caminhos e desvios; os agentes e sua relação com a sociedade, lugares de produção e instituições reguladoras; modelos epistemológicos e técnicas; terrenos de atuação e tipo de prática" ${ }^{\circ 8}$.

Preocupação crítica de inspiração foucaldiana que se fez sentir, um pouco antes dos livros de Machado e Freire Costa, em outra obra menos conhecida pelos pesquisadores em Ciências Humanas, a tese de doutorado "O Dilema Preventivista: contribuição para a compreensão e crítica da Medicina Preventiva", apresentada em 1975 por Sérgio Arouca à Faculdade de Ciências Médicas da Universidade de Campinas. Antes que os althusserianos brasileiros traduzissem $O$ normal e o patológico, em 1978, e introduzissem o posfácio de Althusser e Macherey, em 1982, as referências àquela tradução argentina prefaciada por Lecourt,

\footnotetext{
${ }^{67}$ MACHADO, Danação da norma, p. 11

${ }^{68}$ FERREIRA, Antonio Celso e LUCA, Tania Regina. "Medicina e práticas médicas em São Paulo: uma introdução", p. 15.
} 
de 1971, eram constantes entre os autores que ajudaram a constituir o campo da Saúde Coletiva no Brasil. Sérgio Arouca, em $O$ dilema preventivista, Cecília Donnangelo, em Medicina e estrutura social, e Ricardo Bruno Mendes Gonçalves, em Medicina e História, articulam, com pouca cerimônia, as ideias de Althusser, Canguilhem, Foucault e Lecourt ${ }^{69}$. Se não podemos determinar se Sérgio Arouca e os pesquisadores agrupados na escola uspiana de Saúde Coletiva ${ }^{70}$ foram de fato os primeiros no Brasil a ler ou citar os filósofos-historiadores franceses, ou a incluílos nas referências bibliográficas de um trabalho qualquer, certamente foram os primeiros a fazer de $O$ normal e o patológico e de $O$ nascimento da clínica os leitmotivs de uma reflexão original, nesse caso, uma reflexão sobre a historicidade da prática e do pensamento médico e sobre o processo saúde-doença nas populações, conferindo um conteúdo original à fortuna crítica de Canguilhem e Foucault. Sobre essa recepção, Naomar de Almeida Filho e Maria Thereza A. D. Coelho escreveram o seguinte no artigo "Normal-Patológico, Saúde-Doença: Revisitando Canguilhem":

Uma interessante hipótese de história das ciências, a ser devidamente considerada, pelo menos para alguns desses autores, é que essa referência [aos trabalhos de Canguilhem e Foucault] teria funcionado, dentre outros motivos, como uma camuflagem da base teórica marxista das análises propostas, num momento de intensa repressão política e censura ideológica. Faz parte do anedotário da época que o capítulo metodológico da tese de Sérgio Arouca (1975) sobre o "Dilema Preventivista" (...) havia sido escrito de modo hermético e propositalmente pouco compreensível, justamente para desencorajar censores e outros leitores indesejados. Desse modo, tanto Foucault quanto Canguilhem inadvertidamente vieram a adquirir, na literatura sanitarista latinoamericana, uma respeitosa consideração como expoentes teóricos de um pensamento epistemológico de esquerda. ${ }^{71}$

\footnotetext{
${ }^{69}$ AROUCA, Sérgio. O dilema preventivista: contribuição para a compreensão e crítica da medicina preventiva. Tese de doutorado, Faculdade de Ciências Médicas da UNICAMP, 1975; DONNANGELO, Cecília. Medicina e Estrutura Social. São Paulo. Tese de Livre-docência, Faculdade de Medicina da USP, 1976; GONÇALVES, Ricardo Bruno Mendes. Medicina e história: raizes sociais do trabalho médico. São Paulo. Dissertação de Mestrado, Faculdade de Medicina da USP, 1979. Na bibliografia da tese de Arouca, por exemplo, Althusser só é mais citado que Foucault, e, além da tradução argentina de Le normal et le pathologique, Arouca também indica a leitura do artigo de Canguilhem sobre "O objeto da história das ciências", traduzido em 1972 pela Revista Tempo Brasileiro, porto seguro dos althusserianos brasileiros. Também pela editora Tempo Brasileiro, Arouca lista a tradução, naquele mesmo ano de 1971, do artigo "A arqueologia e o saber", de Dominique Lecourt.

${ }^{70}$ Foi Ricardo Bruno Mendes Gonçalves (No prefácio a AYRES, José Ricardo de Carvalho Mesquita. Epidemiologia e emancipação. Rio de Janeiro: Hucitec/ABRASCO, 1995) quem primeiro chamou a atenção para a existência de uma "escola", constituída a partir da obra e do ensino de Cecília Donnangelo no Departamento de Medicina Preventiva da Universidade de São Paulo, e da qual ele mesmo foi um dos mais importantes contribuidores.

${ }^{71}$ ALMEIDA FILHO, Naomar de; COELHO, Maria Thereza A. D. "Normal-Patológico, Saúde-Doença: Revisitando Canguilhem", p. 15.
} 
Eles continuam:

Da parte de Foucault, essa aura foi rapidamente revisada, por iniciativa principalmente do próprio autor, com sua guinada genealógica nietzschiana, no início da década de oitenta (...). O mesmo não ocorreu com a epistemologia de Canguilhem, que, protegido de análises críticas mais profundas, talvez pelo desconhecimento do conjunto da sua obra [nesse ponto, em nota de rodapé, Ricardo Bruno Mendes Gonçalves e José Ricardo de Carvalho Mesquita Ayres são indicados como exceções], continuou a ser referida como base conceitual para importantes empreendimentos teóricos fundamentados no marxismo no campo da Saúde Coletiva. O exemplo mais marcante desse efeito talvez seja a teoria do 'processo de trabalho e saúde', elaborada por Laurell e colaboradores, extremamente influente na área de Saúde do Trabalhador, que toma, em segunda mão, a expressão 'modo de andar a vida', supostamente originária da obra de Canguilhem, como conceito-chave. ${ }^{72}$

Essa expressão destacada por Naomar de Almeida Filho e Maria Thereza A. D. Coelho, "modos de andar a vida", abre espaço para uma reflexão interessante sobre a relação entre circulação e recepção a partir do tema da tradução. Uma pesquisa rápida na internet indicará uma série de trabalhos acadêmicos de pesquisadores brasileiros interessados pelo tema dos "modos de andar a vida segundo Georges Canguilhem”. Essa linha de pesquisa tem sua origem naquela tradução argentina de 1971, como dissemos, bastante citada pelos formadores do campo da Saúde Coletiva no Brasil e pelos sanitaristas latino-americanos. Sérgio Arouca, em $O$ dilema preventivista, citando a tradução argentina, escreveu: "O cuidado médico dirige-se a necessidades humanas, consideradas como condições de saúde e de doença, que entendemos no sentido de CANGUILHEM (1971) como modos inéditos 'de andar a vida', nos quais a vida, comparativa e historicamente, recusa as normas da doença para afirmar a normatividade da saúde" ${ }^{\text {"73 }}$. A edição argentina traduziu a palavra francesa "allure" por uma expressão que, em português, é mais próxima de seu sentido literal de passo, trote, logo, "modo de andar", enquanto Canguilhem a emprega enquanto postura, modo de se apresentar, enfim, "manifestação", um conceito importante no livro. Basta dizer que, em $O$ normal e o patológico, Canguilhem define a fisiologia como "ciência das manifestações estabilizadas [allures stabilisées] da vida"74 . Na mesma página, Canguilhem escreveu: "Falamos, diversas vezes, de manifestações da vida [allures de la vie], preferindo em alguns casos essa expressão ao termo comportamento [comportement] para deixar mais claro que a vida é polaridade dinâmica." Ainda na mesma página, Canguilhem escreveu: "Há dois tipos de manifestações inéditas da vida [allures inédites de la vie]”. A favor da tradução

\footnotetext{
${ }^{72}$ Ibidem, p. 15-16.

${ }^{73}$ AROUCA, O dilema preventivista, p. 154.

${ }^{74}$ CANGUILHEM, Le normal et le pathologique, p. 136.
} 
argentina, pesa a constância da escolha pela expressão "modos de andar" em todas as ocasiões em que, no texto original, Canguilhem escreveu "allures". Arouca, leitor atento de Lo normal y lo patológico, graças a essa constância, pôde fazer um uso bem ponderado do texto de Canguilhem. Já na tradução brasileira, nesses trechos que acabamos de citar, a expressão "allures de la vie" é traduzida por "modos de ser da vida", enquanto a fisiologia se torna a "ciência dos ritmos estabilizados [allures stabilisées] da vida". O que mais impressiona é que, poucas linhas após Canguilhem ter feito aquela distinção, de extrema importância, entre "allures" e "comportement" a tradução brasileira registre: "Há dois tipos de comportamento inéditos da vida [allures inédites de la vie]". Três traduções diferentes para o mesmo conceito, na mesma página.

Em outro trecho de $O$ normal e o patológico, a palavra allures é traduzida por "manifestações", que nos parece a escolha adequada, por expressar melhor que "modos de ser" o dinamismo da vida. Mas em nenhum lugar da tradução brasileira a palavra allures é traduzida como "modos de andar", opção da tradução argentina, o que acabou criando uma situação inusitada, na qual alguns autores brasileiros seguem fazendo referência ao "conceito canguilhemiano" de "modos de andar a vida" sem saber indicar onde esse conceito se encontra, apresentando geralmente apenas a referência a $O$ normal e o patológico, mas sem jamais informar a página onde o conceito supostamente aparece, ou mesmo uma citação que comprove seu uso por Canguilhem. É o caso da dissertação de mestrado "Estresse e modos de andar a vida: subsidios de Georges Canguilhem para uma etnoepidemiologia da Síndrome Geral da Adaptação na cidade de São Paulo", de Maurici Tadeu Ferreira Santos, exemplo que escolhemos, entre muitos outros possíveis, apenas por associar, já no título, o nome de Canguilhem àquela expressão.

Mas o tema dos "modos de andar a vida" está longe de ser o aspecto mais vivo e interessante da recepção das ideias de Canguilhem no Brasil. Por exemplo, José Ricardo de Carvalho Mesquita Ayres, num artigo recente publicado na revista Intelligere, escreveu sobre a importância - teórica, e não apenas política - da obra de Canguilhem para a formação do campo da Saúde Coletiva no Brasil ${ }^{75}$. Mas é importante dizer que se, a partir dos anos 70, na América Latina, Canguilhem pôde se tornar um dos "expoentes teóricos de um pensamento epistemológico de esquerda" na área da saúde, como escreveram Naomar de Almeida Filho e Maria Thereza A. D. Coelho, foi também porque a obra de Canguilhem, tal como apresentada aos seus leitores fora da França, permitia problematizar o conhecimento em saúde a partir de bases

\footnotetext{
${ }^{75}$ Cf. AYRES, "Georges Canguilhem e a construção do campo da Saúde Coletiva brasileira". Intelligere, [S.1.], v. 2, n. 1, p. 139-155, maio 2016.
} 
consideradas "verdadeiramente racionais", aquelas do materialismo histórico. Uma questão original dos pesquisadores brasileiros que, no quadro das transformações no campo da medicina social experimentada na América Latina, tomou a forma de uma reflexão sobre a prática e o pensamento médico nas sociedades capitalistas a partir de uma abordagem histórica e epistemológica dos conceitos de "vida", "norma", "normal", "patológico", "saúde" e "doença". Consideremos as palavras esclarecedoras de Ricardo Lafetá Novaes, em "A saúde e os conceitos", dissertação de mestrado defendida em 1976 junto ao Departamento de Medicina Preventiva da USP (onde mais tarde viria a ser professor, embora não integrasse a chamada "escola uspiana de saúde coletiva"):

Canguilhem nos aparece como um autor da maior importância no momento mesmo em que toma as categorias médicas e biológicas como objeto de reflexão, a partir de uma perspectiva histórica das ciências (ideologias) que constituíram a vida como objeto de conhecimento. Perspectiva histórica que é também epistemológica e que nos indica não só a pré-história de uma ciência, mas também de como elas se envolvem (são envolvidas, melhor dizer) com as concepções gerais do mundo, fazendo suas categorias e valores sociais que mais expressam os interesses dominantes do que a verdade do seu objeto. Contra as tendências mecanicistas de se pensar a vida, Canguilhem propõe um certo vitalismo que, se exige alguma restrição, força, justamente por isso, uma reflexão mais cuidadosa sobre a articulação de duas ordens: a biológica e a social. Aceitar que a vida é um debate que o ser vivo estabelece com o meio que lhe é próprio, que viver é propor novas formas de realização a um meio que é também criado, é colocar a possibilidade de se pensar a normatização da vida não só do ponto de vista de uma normatividade biológica do organismo, mas também da instalação de novas normas numa sociedade polarizada em classes. Se Canguilhem não responde a todas as questões, nos indica, ao encontrar na norma a anterioridade do habitual, da média e do mais frequente, o caminho a percorrer na identificação dos valores atribuídos à normalidade do ser humano. Apoiando-nos largamente nas suas reflexões, queremos dizer do reconhecimento da fecundidade do seu pensamento, reforçando-o no interior de um debate necessário e já em andamento em alguns círculos menos conformados. É a partir daí que, e em última análise, perguntamos pelas noções que norteiam o exercício de uma prática e pelo seu caráter. Perguntamos pela sua cientificidade e pelo lugar de onde emana a sua verdade. Em nome de quem a medicina prescreve, é normatizadora, torna-se assim uma questão fundamental. ${ }^{76}$

Arouca também apresenta sua a reflexão histórica sobre a prática e o pensamento médico como tributária da abordagem canguilhemiana. Antes mesmo da defesa da sua tese, Arouca já havia publicado, em 1974, na Revista de Educación Médica y Salud, da Organização Pan-americana da Saúde, o artigo "La arqueologia de la medicina", que ele descreveu como "uma

\footnotetext{
${ }^{76}$ NOVAES, A saúde e os conceitos, p. V.
} 
breve introdução à nova disciplina criada por Michel Foucault - a história arqueológica concretamente no aspecto relativo à medicina". O artigo, embora sobre Foucault, começa com uma referência a Canguilhem:

Según Canguilhem, la historia de las ciencias se define en relación con el discurso metódico que constituye su objeto científico. Por lo tanto, "el objeto del discurso [histórico] es la 'historicidad' del discurso científico, en la medida en que esta historicidad representa la realización de un proyecto interiormente regulado, pero surcado por accidentes, retrasado o desviado por obstáculos, interrumpido por crisis, es decir, momento de enjuiciamiento y verdad". En estas condiciones, la ciencia tiene su propio aspecto, su ritmo y, para expresarnos mejor, su temporalidad específica; procede por reorganizaciones, rupturas y mutaciones; pasa por puntos críticos en los que el tiempo se acelera o se hace más pesado, efectúa bruscas aceleraciones y retrocesos repentinos. ${ }^{77}$

Em 1865, Claude Bernard inaugurou assim a famosa Introdução ao estudo da Medicina Experimental: “Conservar a saúde e curar as doenças: esse é o problema que a medicina se colocou desde a sua origem e para o qual ainda persegue a solução científica."78 A similitude das funções, entretanto, não torna simétricas condutas separadas no tempo. Como explicou Arouca, apoiado em Canguilhem, a recorrência, nas sociedades primitivas, a certos "procedimentos sobrenaturais para o diagnóstico" e "cerimônias médico-religiosas para o tratamento" não está em continuidade com o discurso metódico, interiormente normatizado, que hoje chamamos de medicina. "A conduta preventiva da medicina médico-religiosa", diz Arouca, "não possui o mesmo significado, em termos de conhecimento médico, que aquelas medidas da medicina microbiana ou da medicina preventiva que conhecemos atualmente" ${ }^{\text {,9 }}$. Se a história de uma atividade é constitutiva da forma atual dessa atividade - para expressar numa única frase o significado da noção de "historicidade do discurso científico" emprestada de Canguilhem -, para Arouca, o que se depreende da ideia de uma temporalidade específica, geralmente descontínua,

\footnotetext{
${ }^{77}$ AROUCA e MARQUEZ, "La arqueologia de la medicina”, p. 1. O trecho de Canguilhem citado por Arouca foi traduzido para o espanhol a partir da sua tradução brasileira: CANGUILHEM, Georges. "O objeto da história das ciências". In: Epistemologia. Rio de Janeiro: Tempo Brasileiro, Jan-Mar, 1972, p. 15. A opção pela transcrição do texto em espanhol nesse artigo tem como objetivo evitar o que seria uma tradução da tradução da tradução, o que aumentaria o risco de novas infidelidades, mas também exige alguns esclarecimentos. Primeiro, a palavra '[histórico]' entre colchetes corrige uma inexatidão na tradução de Arouca e Marquez, algo quase insignificante, mas que poderia sugerir se tratar do objeto do "discurso metódico", mencionado anteriormente pelos autores do artigo, e não do objeto do "discurso histórico", sobre o qual falava Canguilhem. Além disso, onde Arouca e Marquez dizem "interiormente regulado", Canguilhem escreveu "interiormente normatizado [normé]", distinção relevante, já que a importância do conceito de "norma" na filosofia de Canguilhem sugere uma escolha judiciosa da palavra. Cf. CANGUILHEM, Georges. "L'objet de l'histoire des sciences", p. 17.

${ }^{78} \mathrm{BERNARD}$, Introduction à l'étude de la médecine expérimentale, p. 31.

${ }^{79}$ AROUCA, O Dilema Preventivista, p. 32-33.
} 
do conhecimento científico é que nem toda prática de cura deve ser inscrita na história da medicina e, portanto, nem toda conduta preventiva pertence à história da Medicina Preventiva. Mas, então, o que o historiador deve fazer entrar na história das ciências? De quê a história das ciências é a história? "Preferimos partir da premissa de que a história das ciências é, basicamente, a história das ideias", sentencia Arouca. Ou seja, para Arouca, o objeto do discurso histórico sobre as ciências são os fatos intelectuais das ciências, mas, e isso é importante, ele acrescenta que as ideias "encontram sua especificidade na relação que possuem com a estrutura social que gerou e permitiu seu aparecimento" ${ }^{\$ 0}$.

Nessa elaboração de Arouca, não há desprezo pela história das práticas, mas uma qualificação derivada daquela especificidade das ideias, da sua posição estratégica nos campos discursivo e não-discursivo. No artigo de Canguilhem "O objeto da história das ciências", publicado em português pela revista Tempo Brasileiro em 1972 e citado por Arouca tanto naquele texto de 1974 quanto em sua tese de doutorado, Canguilhem explica que a história das ciências, como disciplina, “constitui o domínio específico em que as questões teóricas postas pela prática científica em seu desenvolvimento [devenir] encontram seu lugar" ${ }^{\prime \prime}$, e acrescenta uma nota sobre a origem dessa reflexão, o conceito althusseriano de prática teórica: "a prática teórica", diz Althusser, "retorna sob a definição geral da prática. Ela trabalha sobre uma matéria primeira (representações, conceitos, fatos) que lhe são dadas por outras práticas, sejam 'empíricas', sejam ‘técnicas', sejam ‘ideológicas'." 82 E como, para Arouca, os conceitos (mais que as representações e os fatos) são a "matéria primeira" sobre a qual trabalham essas práticas teóricas, "trata-se, por essa forma, de determinar, em dado contexto social, a que tipo de racionalidade o conceito pertence" 83 .

O vigor da tese de Arouca se deve muito ao desvelamento das ideologias e práticas ideológicas que estão na origem das insuficiências da Medicina Preventiva: "a Medicina Preventiva, mais do que a produção de novos conhecimentos, mais do que mudanças na estrutura da atenção médica, representa um movimento ideológico", afirmou logo na sua Introdução. Segundo Guilherme Rodrigues da Silva, orientador de Arouca no doutorado, O Dilema Preventivista foi fundamental para a construção de uma teoria social da saúde no Brasil e tem sido um dos trabalhos mais citados pelos pesquisadores dessa área. A concretização da teoria social à qual se refere Rodrigues da Silva teria se dado através da incorporação da declaração de direito à saúde na Constituição de 1988 e, nos anos seguintes, da institucionalização do Sistema

\footnotetext{
${ }^{80}$ Ibidem, p. 32.

${ }^{81}$ CANGUILHEM. "L'objet de l'histoire des sciences", p. 19.

${ }^{82}$ ALTHUSSER, Pour Marx. Apud CANGUILHEM. "L'objet de l'histoire des sciences", p. 19.

${ }^{83}$ AROUCA, Op. cit., p. 32.
} 
Único de Saúde. É evidente que as limitações da Constituição e do SUS não devem ser colocados na conta de Arouca, e tampouco servem para uma leitura retroativa da sua tese. Se destacamos o seu protagonismo nas discussões políticas sobre a Saúde no Brasil é porque os paradigmas da Saúde Coletiva ali articulados, segundo seus intérpretes, foram lançados por Arouca mais de dez anos antes em sua crítica histórico-epistemológica da Medicina Preventiva, que logo se tornou objeto de ampla discussão nas escolas médicas e serviu de base teórica para a organização do movimento pela Reforma Sanitária da década de 80.

Diferente do que aconteceu na França, onde o interesse pela história da medicina ganha corpo também na história das especialidades médicas e suas racionalidades específicas, no Brasil, o pensamento social em saúde direcionou o olhar dos historiadores para a saúde pública. O movimento político pela reforma sanitária no Brasil, que muitos autores tratam como parte de um "momento revolucionário da medicina social" na América Latina, pôs no centro da discussão a relação entre saúde e sociedade. O que se seguiu foi um predomínio dos estudos históricos sobre saúde pública e a medicina social, os movimentos sociais, o Estado, o sistema de produção. Assim, os estudos sobre "o social da saúde" estariam em continuidade com o projeto político de Arouca e da escola uspiana de formulação de uma teoria social da saúde, mas foram se afastando do modelo historiográfico e epistemológico que eles empregaram.

Mas a tese de Arouca não foi a última contribuição do "estilo francês de história da medicina" para os estudos sobre a epistemologia da saúde coletiva no Brasil. No livro Epidemiologia e Emancipação, José Ricardo de Carvalho Mesquita Ayres afirma: "Por certa afinidade metodológica, e até por expressiva proximidade temática, iniciemos a explicitação da perspectiva epistemológica a ser desenvolvida tomando como ponto de partida sua relação com a escola francesa, a chamada epistemologia histórica". O livro de José Ricardo Ayres, é ele mesmo quem diz, testemunha "uma preocupação com os rumos da saúde coletiva que não abre mão do estudo do desenvolvimento científico da epidemiologia", uma preocupação de quem olha "de dentro" de uma disciplina que passa por uma brusca transformação. O que esse estilo francês exige do historiador é a capacidade de reflexão ao mesmo tempo crítica e política sobre a racionalidade médica, e isso é particularmente verdadeiro nos períodos de crise. Assim, a revolução da medicina social no Brasil, que, a partir do problema das relações entre saúde e sociedade, aproximou sociólogos, antropólogos e historiadores da medicina, sempre exigirá, para ser bem compreendida, um olhar atento à mutação da própria racionalidade médica em um dado contexto social. 


\section{Capítulo 5 \\ Epistemologia histórica e história epistemológica}

Em conferência realizada no ano de 2014 no Centre Alexandre Koyré, em Paris, por ocasião do lançamento da tradução francesa de seu livro Historische Epistemologie, Hans-Jörg Rheinberger contou uma história que nos parece mais que simples anedota. Foi por pressão da editora alemã que o livro foi publicado com o título de "Epistemologia histórica". Já na França, para evitar qualquer confusão com o produto nacional épistémologie historique, hoje pouco valorizado pelo público consumidor de livros no país, a editora impôs o título Introducion à la philosophie des sciences. Apenas na tradução estadunidense Rheinberger conseguiu usar o título originalmente pretendido “On historicizing epistemology”. Em seu livro, Rheinberger se esforça para desnacionalizar as origens da epistemologia histórica, argumentando que a primeira metade do século XX foi palco de um processo de "historicização da epistemologia" que se desenvolveu não apenas na França, mas também na Polônia ou na Alemanha. Mais que a formação de escolas nacionais, o que Rheinberger pretende mostrar é a longa história pela transnacional através da qual autores como Bachelard, mas também Fleck ou mesmo Cassirer vieram a "transformar a historicização da epistemologia em um programa compreensivo". Para ele, essa historicização da epistemologia "constitui a contribuição decisiva do século anterior à transformação da filosofia das ciências"1. Tal apreciação não seria possível se Rheinberger não estabelecesse de partida uma distinção entre epistemologia e teoria do conhecimento:

[Epistemologia] não é aqui utilizada como um simples sinônimo de "teoria do conhecimento", entendida como aquilo que faz com que um saber seja científico, como é o caso na tradição clássica, em particular na tradição anglo-saxã. Seguindo, antes, a utilização desse conceito [de epistemologia] tal como ele é desenvolvido na tradição francesa, nós entendemos por epistemologia a reflexão que trata, por um lado, das condições históricas $s o b$ as quais, e os meios com os quais as coisas são transformadas em objetos de saber e, por outro lado, sobre as maneiras pelas quais o processo de produção científica de conhecimentos é iniciado e desenvolvido. ${ }^{2}$

Sem necessariamente concordarmos com todas as etapas da reconstrução histórica proposta por Rheinberger, vemos grande mérito em sua proposta de compreensão histórica da epistemologia histórica. Nesse espírito, decidimos recuperar parcialmente uma reflexão elaborada num trabalho anterior, a fim de esclarecer as condições históricas para a emergência da ideia de

\footnotetext{
${ }^{1}$ RHEINBERGER, Introducion à la philosophie des sciences, p. 4

${ }^{2}$ Ibidem, p. 5.
} 
"história das ciências" (no plural, que difere radicalmente da ideia de "história da ciência") na filosofia francesa contemporânea. Com isso, pretendemos mostrar em que medida a possibilidade dessa ideia está relacionada à superação de uma teoria do conhecimento, a arquitetônica kantiana, e à historicização da epistemologia proposta por Bachelard.

\section{A historicização da epistemologia: Bachelard, Fleck e Canguilhem}

Segundo Canguilhem, as "condições históricas de possibilidade" para o surgimento da História da Ciência como "gênero literário" no século XVIII foram dadas pela tomada de consciência de duas revoluções científicas e duas revoluções filosóficas: nas Matemáticas, a Geometria algébrica de Descartes e, em seguida, o Cálculo do infinito de Leibniz-Newton; em Mecânica e Cosmologia, os "Principes" de Descartes e "Principia" de Newton. Em Filosofia, e Canguilhem se refere à Teoria do Conhecimento enquanto teoria do fundamento da ciência, o inatismo cartesiano e o sensualismo de Locke.

Sem Descartes, sem ruptura da tradição, uma história das ciências não pode começar. Mas, segundo Descartes, o saber é sem história. É preciso Newton e a refutação da cosmologia cartesiana para que a história, ingratidão do começo reivindicado contra as origens recusadas, apareça como uma dimensão da ciência. A história das ciências é a tomada de consciência explícita, exposta como teoria, do fato que as ciências são discursos críticos e progressivos para determinação daquilo que, na experiência, deve ser tomado por real. O objeto da história das ciências, então, é um objeto não-dado, um objeto para o qual o inacabamento é essencial. ${ }^{3}$

Ainda segundo Canguilhem, livros como Histoire des Mathématiques (1758), de Jean-Étienne Montucla, ou Histoire de l'Astronomie (1775-1782), de Jean Bailly, foram compostos "fora de toda referência a um sistema de conceitos críticos ou normativos", isto é, sem qualquer preocupação epistemológica. Compartilhavam, entretanto, de "uma consciência de época, impessoalmente tematizada na doutrina da perfectibilidade indefinida do espírito humano" que, autorizada pela mesma sucessão de revoluções científicas e filosóficas, não podia evitar "antecipar os progressos científicos vindouros de outra forma que sob o aspecto da continuidade"4. Se o tema da lenta maturação dos progressos do espírito pôde instaurar-se de forma tão natural e necessária nos discursos históricos, é sinal de que ainda não haviam sido

\footnotetext{
${ }^{3}$ CANGUILHEM, "L'objet de l'histoire des sciences", p. 17-18.

${ }^{4}$ CANGUILHEM, "Le rôle de l'épistémologie dans l'histoiographie scientifique contemporaine”, p. 11-12.
} 
dadas as condições históricas de possibilidade da Epistemologia.

Dissemos anteriormente que no artigo "A ideia de epistemologia" Gérard Lebrun pergunta o que deve significar a palavra "ciência" para que o gênero "epistemologia" se torne não apenas aceitável, mas indispensável. "Haverá ao menos um sentido da palavra ciência que impossibilitaria a epistemologia?"5. Aqui, pretendemos entender qual ideia de ciência foi necessária para que se tornasse possível pensar a "história das ciências". Pois não é - ou nem sempre foi - fato evidente que as ciências possuem uma história, que elas são história, que não existe conhecimento científico sem história. Partindo da reflexão indicada por Lebrun, decidimos investigar a partir de que momento da história intelectual emergiu uma ideia de ciência que pudesse ser submetida a esse duplo exame:

a) histórico: as ciências são aventuras contingentes (da razão... se não podemos dispensar uma personagem) e suas proposições podem ser tratadas enquanto acontecimentos, como, ainda que de modo nebuloso, o elogio que Kant dispensa a Tales e a Galileu deixa entrever; b) filológico: é possível conferir-lhes o estatuto de um texto e considerar cada uma delas como um corpus de fórmulas (enunciados, protocolos, indicações de pesquisa...) no qual se deposita um trabalho coletivo, cujas articulações exprimem escolhas ou decisões. Essa segunda condição pode ser mais bem enunciada da seguinte maneira: o fato de haver "história da ciência" implica que a palavra epístasthai designa uma aventura; o fato de haver epistemologia implica que designa uma estratégia. Nada mais que isso. ${ }^{6}$

Segundo Lebrun, a epistemologia não era possível enquanto não fosse permitido às ciências ter uma história própria, isto é, enquanto admitia-se que a Razão homogênea, a "scientia generalis", produzia todos os critérios de racionalidade dos quais as ciências particulares eram apenas a objetivação. De acordo com Lebrun, mesmo que a Crítica kantiana não sirva de manual para a epistemologia (afinal, quando Kant pergunta “como é possível a Matemática pura?”, na

\footnotetext{
${ }^{5}$ LEBRUN, "A ideia de epistemologia", p. 130.

${ }^{6}$ Ibidem, p. 137-138. No texto original, logo após a definição do exame histórico, há uma nota em que Lebrun faz uma longa citação de Georges Canguilhem acerca do conceito de acontecimento: "'De certo ponto de vista todo juízo científico é um acontecimento. O pesquisador não sabe como encontrará aquilo que ele procura; se não fosse assim, já estaria ali ou visível. Talvez seja a ilusão de uma época, posteriormente refutada, que teria levado a estabelecer um fato, que surgiu onde não se esperava, no final de uma pesquisa, sem dúvida esclarecida pelos erros da anterior, mas inconsciente, então, de seu próprio futuro. Negar essa eventualidade seria admitir que só há ciência na exploração de idéias ou fatos e nunca na invenção deles. Mas para além da palavra 'sabemos', há 'nem sempre soubemos'. Na sombra dessa negação no passado se dissimula toda a história de uma questão. E essa história deve ser escrita como uma história e não como uma ciência. Como uma aventura, e não como uma exposição.' (G. Canguilhem, Formation du concept de réflexe, aux XVII et XVIII siècles. Paris: PUF, 1955, PP 156-157)."
} 
verdade ele quer saber como são possíveis os juízos sintéticos "a priori”, ou seja, questiona-se sobre o uso teórico da razão em geral e as possibilidades da Metafísica como ciência), foi nela que despontou pela primeira vez essa "atitude do epistemólogo", que conduz à heterogeneidade das ciências ${ }^{7}$. Kant fez com que a própria razão interrogasse as ciências para responder a pergunta que, enfim, resume a primeira Crítica: "O que posso saber?".

A tese de que a razão tomaria conhecimento de si e dos seus poderes a partir dos questionamentos que faz às ciências particulares introduz um tema nada óbvio da filosofia kantiana e que chegará praticamente intacto até Léon Brunschvicg, orientador de Gaston Bachelard: o de uma história transcendental da razão. O Racionalismo cartesiano-platônico no século XVII, tão criticado por Brunschvicg e Bachelard, fez da razão algo eterno, não-temporal, que implicava numa interpretação da História como um fenômeno contingente meramente empírico, sem qualquer relevância racional. Foi o Historicismo emergente no século seguinte que mudou essa perspectiva clássica, conduzindo a filosofia não apenas à busca por uma função "racional" da História, mas também à necessidade de um fundamento sistêmico que permitisse a historicização da razão. Hegel, que fez da historicização da razão um movimento necessário para sua "ascensão ao status de verdade eterna", na verdade desenvolvia um tema já implícito na filosofia de Kant, para quem as formas transcendentais da razão seriam constituídas pelo sujeito racional.

Para Kant, o que faz da Metafísica um "teatro de disputas infindáveis" é o fato de que a razão não seja completamente conhecida a si mesma, mas dependa do combate entre os sistemas filosóficos, da "diversidade de ideias que ocasionou as principais revoluções" na história da razão pura ${ }^{8}$. Mas essa história é finita, afirma Kant. Na verdade, a historicidade da razão depende da sua finitude e a Crítica tem um papel a cumprir, pois, segundo Kant, a Metafísica perdeu o seu prestígio de "rainha de todas as ciências" no momento em que a batalha infértil entre dogmáticos e céticos conduziu ao enfado e ao indiferentismo "que engendram o caos e a noite nas ciências, mas também, ao mesmo tempo, são origem, ou pelo menos prelúdio, de uma próxima transformação e de uma renovação dessas ciências". ${ }^{9}$ Por isso na Crítica da Razão Pura Kant lamentou a necessária historicidade da razão:

É lamentável que só depois de ter passado muito tempo, orientado por uma ideia profundamente escondida em nós, a reunir rapsodicamente, como materiais, muitos conhecimentos que se reportam a essa ideia e mesmo depois de os ter por muito tempo disposto de uma maneira técnica, nos seja enfim possível, pela

\footnotetext{
${ }^{7}$ LEBRUN, "A ideia de epistemologia", p. 137.

${ }^{8}$ KANT, Crítica da razão pura, A 853 / B 881.

${ }^{9}$ KANT, Crítica da razão pura, A X.
} 
primeira vez, ver a ideia a uma luz mais clara e esboçar arquitetonicamente um todo segundo os fins da razão. ${ }^{10}$

Sabemos que, para Kant, não pode haver uma polêmica autêntica no campo da razão pura, ou seja, ela não pode estar em desacordo consigo mesma. Se, por vezes, tem-se essa impressão, que, no limite, pode levar à negação da própria racionalidade científica, é apenas porque tomamos como intransponíveis as dificuldades que as diversas doutrinas impõem umas às outras e optamos pela confissão de ignorância em determinadas questões como parte de um “cálculo perfeitamente inútil” para proporcionar repouso à razão, escreveu. Para Kant, entretanto, a consciência de sua ignorância, em vez de pôr termo às suas investigações, "é, pelo contrário, a verdadeira causa que as suscita", no mínimo "um meio excelente de despertar a razão do seu doce sonho dogmático e conduzi-la a um exame cuidadoso do seu estado". ${ }^{11}$ Esse exame cuidadoso, isto é, a própria investigação crítica sobre os limites do conhecimento possível, conduziu Kant a uma compreensão filosófica da história da filosofia que garantiu um fundamento sistêmico para as suas inevitáveis contradições: a história da filosofia seria a forma historicizada da arquitetônica da razão pura, o lugar onde seus componentes individuais apareceriam desconectados e em aparente oposição entre si, o que significa afirmar que as controvérsias na história da filosofia teriam a sua origem na própria natureza da razão pura ${ }^{12}$.

A ideia de uma "razão arquitetônica" é sustentada, portanto, por um princípio teleológico para a satisfação dos fins essenciais da razão humana, cujo esclarecimento - através da Crítica - impediria os nossos conhecimentos em geral de formarem o que Kant chama de "rapsódia". Nesse cenário, a sucessão histórica das doutrinas filosóficas e científicas seria contingente apenas em sua ordem de disposição no tempo em função dos problemas específicos que lhes são impostos pela experiência, mas sua manifestação é necessária, pois todas elas são "membros históricos de um todo orgânico; elas são governadas pela arquitetônica da razão e gradualmente trazem sua harmonia à luz". E qual a definição de "arquitetônica" oferecida por Kant?

Por arquitetônica entendo a arte dos sistemas. Como a unidade sistemática é o que converte o conhecimento vulgar em ciência, isto é, transforma um simples agregado desses conhecimentos em sistema, a arquitetônica é, pois, a doutrina do que há de científico no nosso conhecimento em geral e pertence, assim, necessariamente, à metodologia. ${ }^{13}$

\footnotetext{
${ }^{10}$ KANT, Crítica da razão pura, A 834 / B 862.

${ }^{11}$ KANT, Crítica da razão pura, A 757 / B 785.

12 YOVEL, Kant and the Philosophy of History, p. 227-230, passim.

${ }^{13}$ Kant, Crítica da razão pura, A 832 / B 860.
} 
Foi nesse ponto que Lebrun pôde localizar o "tema epistemológico propriamente dito (no final das contas, pouco considerado)" da filosofia Crítica. Pois quando Kant define a arquitetônica como a doutrina do que há de científico no nosso conhecimento em geral, ele não está falando de um determinado tipo de conhecimento, mas de um status teórico de certeza apodítica desejado para a Filosofia porque supostamente já alcançado pelas ciências fundadas na razão, isto é, aquelas capazes de determinar a priori os seus objetos, como seriam, para Kant, a Matemática e a Física.

A Matemática, Kant escreveu, alcançou cedo esse status através de uma "revolução no modo de pensar", pois, ainda que os egípcios tenham, durante muito tempo, feito dela um uso apenas "tateante", "no admirável povo grego, a matemática entrou na via segura de uma ciência": ao demonstrar o triângulo isósceles, Tales, segundo Kant, teria percebido que a figura geométrica deveria ser construída pela razão e, para conhecê-la com certeza "nada deveria atribuir-lhe senão o que fosse consequência necessária do que nela tinha posto, de acordo com o conceito."14 A Física, por sua vez, teria demorado muito mais para alcançar o status de ciência, pois se tratava, para ela, de "procurar os elementos da razão pura naquilo que se pode confirmar ou refutar por uma experimentação". Numa breve história do método experimental que vai de Galileu a Stahl, passando por Torricelli, Kant localiza também uma "revolução no modo de pensar", que levou à Física a ideia de "procurar na natureza (e não imaginar), de acordo com o que a razão nela pôs, o que nela deverá aprender e que por si só não alcançaria saber""15. Mas, segundo Lebrun,

é a razão, tornada autocrítica, que deverá reporta-se a elas [Matemática e Física]
para conhecer as condições de sua competência, para saber até onde se estende
seu direito de determinar objetos. Se porventura essas ciências não tivessem sido
instauradas, a razão não saberia nem o que ela é nem qual é o seu poder. É
somente com a ajuda dos paradigmas científicos da modernidade que ela pode se
compreender - e graças a essas 'revoluções súbitas' do nosso modo de pensar
(que posteriormente chamamos de 'epistemológicas'). ${ }^{16}$

Kant partiu de um diagnóstico cultural, o estatuto de cientificidade reconhecido à Geometria Euclidiana e à Física Newtoniana "por efeito de uma revolução súbita"17, para deduzir regressivamente o caminho que a metafísica deveria seguir para tornar-se, também ela, uma ciência. Se Copérnico logrou sucesso justamente por inverter a concepção que "admitia que toda

\footnotetext{
${ }^{14}$ KANT, Crítica da razão pura, B X - B XII, passim.

${ }^{15}$ KANT, Crítica da razão pura, B XII - B XIV, passim.

${ }^{16}$ LEBRUN, "A ideia de epistemologia", p. 136-137.

${ }^{17}$ KANT, Crítica da razão pura, B XVI.
} 
a multidão de estrelas se movia em torno no espectador", fazendo, em vez disso, "girar o espectador e deixar os astros imóveis", talvez o fracasso da metafísica repousasse na pretensão de conhecer algo a priori a partir da intuição dos objetos, quando, na verdade, deveria fazer o objeto dos sentidos "se guiar pela natureza da nossa faculdade de intuição". ${ }^{18}$ Assim, a Crítica se apresenta como um tratado acerca do método, cuja tarefa "consiste neste ensaio de alterar o método que a metafísica até agora seguiu, operando assim nela uma revolução completa, segundo o exemplo dos geômetras e dos físicos"19, que colocaria o sujeito transcendental cognoscente numa relação criadora com os objetos da experiência - a chamada revolução copernicana.

O argumento que Kant, nos Prolegômenos, chama de método "sintético", que faz iniciar a investigação sobre a racionalidade científica no questionamento do método das ciências particulares e das suas revoluções ao longo da história, é uma exigência para a elucidação dos fundamentos da racionalidade científica. Essa exigência, por sua vez, é determinada historicamente pelo surgimento, no século XVIII, do movimento intelectual que hoje conhecemos por newtonianismo, que propagou o sucesso do modelo teórico e explicativo newtoniano para todos os campos do conhecimento, inclusive a Filosofia e a História ${ }^{20}$. Segundo Yrmiahu Yovel, importante comentador da chamada "antinomia histórica kantiana" esse "novo produto cultural", a ciência newtoniana, aos olhos de Kant, conteria em substância novas perspectivas da razão em relação à metodologia e à metafísica, mas que precisavam ser elucidadas e fundamentadas a priori, posto que a sua correta aplicação aos fenômenos da natureza apenas pressupunha os princípios metafísicos já em uso.

Isso define a tarefa da metafísica crítica e imediatamente a torna possível. Ela tem que explicar o quadro conceitual da experiência objetiva, que conduz os produtos da razão de volta para a sua origem na consciência transcendental. Esse procedimento garante às ciências empíricas a sua fundamentação. Porém - o mais importante para Kant -, ele abre o caminho para que a metafísica obtenha o

18 KANT, Crítica da razão pura, B XVI - B XVII. Sobre a intuição: "Sejam quais forem o modo e os meios pelos quais um conhecimento se posa referir a objectos, é pela intuição que se relaciona imediatamente com estes e ela é o fim para o qual tende, como meio, todo o pensamento. Esta intuição, porém, apenas se verifica na medida em que o objeto nos for dado; o que, por sua vez, só é possível, [pelo menos para nós homens,] se o objecto afectar o espírito de certa maneira. A capacidade de receber representações (receptividade), graças à maneira como somos afectados pelos objectos, denomina-se sensibilidade. Por intermédio, pois, da sensibilidade, são-nos dados objectos e só ela nos fornece intuições; mas é o entendimento que pensa esses objectos e é dele que provêm os conceitos. Contudo, o pensamento tem sempre que referir-se, finalmente, a intuições, quer directamente (directe), quer por rodeios (indirecte) [mediante certos caracteres] e, por conseguinte, no que respeita a nós, por via da sensibilidade, porque de outro modo nenhum objecto nos pode ser dado" (A 17 / B 31).

19 KANT, Crítica da razão pura, B XXII.

$20 C F$. ALBIERI, Sara Albieri. "Razão e Experiência na Constituição do Conhecimento Histórico: reflexões sobre os aspectos indiciários do paradigma newtoniano", Dimensões, [vol.] 24, (2010), p. 288. 
mesmo sucesso que a física, i.e., o status de ciência. Isso não é apenas a essência do argumento transcendental regressivo de Kant, mas também um pré-requisito para a Crítica como um todo. Internamente, o sistema da razão pode ser organizado e justificado pelos seus próprios meios. Mas, historicamente, a Crítica não teria um solo de onde emergir, a não ser que o tipo de experiência do qual ela é a pura conceitualização já existisse. ${ }^{21}$

Nada de estranho nisso, principalmente se lembrarmos que a lei moral é explicada por Kant a partir da experiência moral atual e a religião da razão repousa nas diversas Igrejas antes de ser completamente explicada. De maneira semelhante, a história da filosofia e a história das ciências antecipam a história transcendental da razão. Mas o objetivo de Kant ao investigar a Matemática e a Física é justamente pôr um fim à história da razão pura, pois, elucidando todas as suas exigências a partir da análise das verdadeiras ciências racionais, será possível não apenas compreender os paradigmas latentes das doutrinas filosóficas em conformidade histórica com a arquitetônica - o que nós vínhamos fazendo -, mas também orientar o caminho da filosofia de acordo com os fins da razão - o que nós devemos fazer. Trata-se, finalmente, após uma longa história de disputas no campo da razão pura, da possibilidade de uma ciência da ciência.

Kant afirma, "sob o domínio da razão não devem os nossos conhecimentos em geral formar uma rapsódia, mas um sistema, e somente desse modo podem apoiar e fomentar os fins essenciais da razão". 22 Tarefa da Crítica, quando estabelecidas as exigências metodológicas não apenas para a elevação da Metafísica ao status de ciência, mas também para todo o conhecimento em geral que tenha as mesmas pretensões, isso permitirá que a metafísica se livre das disputas inférteis e possa conduzir seguramente - e, dessa vez, intencionalmente - a razão ao total conhecimento de si. Então, últimas palavras de Kant no seu livro que termina, não à toa, com um capítulo sobre "A história da razão pura", caberá ao leitor que tomar a via crítica como "um atalho ou estrada real" julgar se "o que tantos séculos não puderam executar não poderia ser alcançado antes do fim deste, ou seja, conduzir a razão humana até a plena satisfação". ${ }^{23}$

Mas, como dissemos, se a Crítica inaugura a atitude do epistemólogo, que vai às ciências particulares, ela não inaugura a ideia de epistemologia e, corolário, não inaugura a ideia de história das ciências. A compreensão da filosofia e das ciências como formas historicizadas da arquitetônica da razão pura é justamente o que tornava impossível, no século XVIII, a ideia de história das ciências. Não pode haver Epistemologia se não se admite que as ciências produzam os seus próprios critérios de racionalidade; e se os fundamentos das ciências devem ser buscados a priori, também não pode haver "história das ciências" no sentido contemporâneo do termo, mas 
apenas "história da ciência", ou seja, apenas a história da elucidação de uma racionalidade estruturada a priori e que deveria fundamentar nossos conhecimentos em geral, mas devidamente ilustrada pelo anedotário das teorias e descobertas científicas em ordem de sucessão progressiva e cumulativa (é nesse sentido que Canguilhem se queixará de um "rebaixamento" da História das Ciências ao papel de mera curiosidade filosófica). História das Ciências, no plural, exige o reconhecimento da heterogeneidade das ciências, o que não podia ser pensado enquanto a razão pura não deixasse de lançar sobre elas "o olhar egoisticamente benévolo do genitor" ${ }^{24}$. Daí que, segundo Bachelard, para a libertação das ciências, para a possibilidade mesmo da Epistemologia e da História das Ciências, era preciso se insurgir contra a arquitetônica. Afinal, de qual função poderia encarregar-se uma teoria do conhecimento em que ciência alguma é considerada produtora de sua própria racionalidade?

A tese sustentada por Bachelard é que se não fosse pelas ciências particulares, a razão jamais tomaria conhecimento de si. Tanto Lebrun quanto Canguilhem lembram a mordacidade costumeira de Bachelard: “A aritmética não está fundada na razão. É a doutrina da razão que está fundada na aritmética elementar. Antes de saber contar, eu não tinha a menor ideia do que era a razão". ${ }^{25}$ Essa tese fundamentou uma ruptura tanto em Epistemologia como em História das Ciências, pois permitiu a formulação de um problema original, que pode ser descrito da seguinte maneira: "Como uma ciência particular produz, ao longo de sua história, os seus próprios critérios de racionalidade?”. É toda essa história da filosofia, que passa pela receoção de Kant na França, que está por trás da avaliação de Pierre Macherey segundo a qual a primeira novidade trazida pelos trabalhos de Bachelard e Canguilhem à história das ciências foi uma "exigência elementar e, por isso mesmo, frequentemente negligenciada: o respeito escrupuloso à realidade da ciência real". Vale a pena lembrar essa passagem já citada no primeiro capítulo, agora em novo contexto:

Os novos epistemólogos [o artigo citado é de 1964] são semelhantes aos etnólogos, que vão 'ao campo': eles vão ver a ciência de perto, e não aceitam falar daquilo que eles ignoram, ou daquilo que conhecem apenas de segunda ou terceira mão (infelizmente é o caso de Brunschvicg) ou percebem de fora, quer dizer, de longe. Essa simples exigência de honestidade e de conhecimento científico frente a frente com a realidade de que se fala subverteu os problemas da epistemologia clássica. Os epistemólogos modernos simplesmente descobriram que as coisas não se passam nas ciências como nós acreditávamos,

24 LEBRUN, “A ideia de epistemologia”, p. 136.

25 BACHELARD, La philosophie du non, p. 144, apud Georges Canguilhem, "Dialetique et philosophie du non chez Gaston Bachelard”, p. 200. Lebrun (“A ideia de epistemologia”, p. 136) cita Bachelard a partir desse artigo de Canguilhem. 
e em particular como acreditavam os filósofos. ${ }^{26}$

A ideia de "história das ciências" foi uma das principais conquistas da filosofia das ciências e, na França, Bachelard foi o arauto desse processo que chamamos de "historicização da epistemologia". Seguindo a proposta de Rheinberger, para quem a historicização das ciências não foi um fenômeno nacional francês, mas uma exigência imposta a diferentes autores e escolas filosóficas no início do século passado, entendemos que a epistemologia histórica pode ser entendida como aquilo que o próprio Bachelard chamou de síntese histórica ${ }^{27}$, uma nova estética dos pensamentos em História das Ciências, ou ainda, um estilo de pensamento. Por isso, ao direcionarmos nosso olhar para fora da França, notamos que é possível, por exemplo, incluir o polonês Ludwik Fleck entre aqueles epistemólogos que, segundo Macherey, "são semelhantes aos etnólogos", "que vão ver as ciências de perto". A obra de Fleck nasce no interior de uma tradição em filosofia da medicina que emerge na Polônia no final do século XIX, dedicada ao estatuto epistemológico do saber médico, à classificação das doenças e à interação entre ciência e sociedade $^{28}$. É desse lugar institucionalmente reconhecido à história e à filosofia da medicina no interior da formação médica que sairá a crítica de Fleck à condição a-histórica da teoria do conhecimento do positivismo lógico e, em particular, ao pensamento de Carnap e ao Círculo de Viena. Apesar dos contextos intelectuais completamente distintos, a compreensão da historicização das ciências como um acontecimento maior na história intelectual europeia permitiu que Rheinberger dedicasse um capítulo de seu livro sobre a historicização da epistemologia às aproximações possíveis entre Gaston Bachelard e o médico polonês Ludwik Fleck, dois autores cujos projetos de crítica da teoria do conhecimento tornariam difícil a sua inclusão em qualquer tradicional escola europeia de filosofia das ciências.

Para seus contemporâneos, Fleck e Bachelard eram, do ponto de vista da filosofia, marginais que não pertenciam a nenhuma tradição definida. Ainda que cada um deles tenha tido sua própria maneira de fazer, e ainda que suas perspectivas de especialistas tenham sido diferentes, ambos conferiam uma importância central a duas coisas: primeiro, o caráter experimental do saber moderno; segundo, seu caráter social. ${ }^{29}$

É digno de nota que Rheinberger chame a atenção para o caráter social da epistemologia

\footnotetext{
${ }^{26}$ Pierre Macherey, "La philosophie de la science de Georges Canguilhem: Epistémologie et Histoire des Sciences", p. 63.

${ }^{27}$ Gaston Bachelard, “O que é uma síntese histórica?”. In: Dominique Lecourt (org.), A epistemologia (Lisboa: Edições 70, 1971), p. 183.

${ }^{28}$ Christiane Sinding, "Histoire de l'histoire de la médecine", p. 577.

${ }^{29}$ RHEINBERGER, Op. cit., p. 29.
} 
bachelardiana. Já se tornou anátema dizer que Bachelard nega "qualquer influência social na mudança científica"30. Porém, o papel desempenhado pela ciência durante a Segunda Guerra chamou a sua atenção para a determinação do social sobre os interesses perseguidos pelas ciências. Em 1953, no livro Le matérialisme rationnel, Bachelard afirmava claramente: "as substâncias estudadas pelo materialismo instruído não são mais dados naturais propriamente ditos. Sua etiqueta social é de agora em diante uma marca profunda. O materialismo instruído é

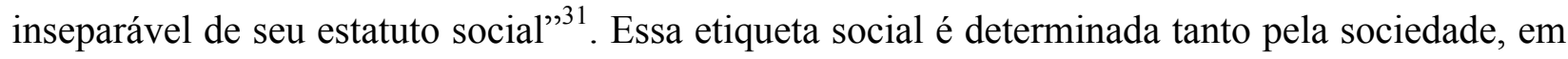
sentido mais amplo, quanto pelo fato de que os cientistas não lidam mais com objetos naturais, mas com objetos socialmente construídos e legitimados enquanto objetos científicos pela comunidade científica, que não vive fora da história social. Passado pouco tempo desde a utilização das primeiras armas atômicas, Bachelard anunciava que vivíamos num período da história em que a Física e a Química nuclear marcavam definitivamente sua importância no futuro dos homens, "tão grande é a verdade do destino do homem estar ligado aos seus pensamentos". A Guerra mostrou a Bachelard que o crescimento dos conhecimentos sobre as possibilidades da matéria dava aos homens meios de poder que ultrapassavam "todos os sonhos de poder do filósofo".

Enquanto a vontade de poder era primitiva, enquanto era filosófica, enquanto era nietzschiana, não era eficaz - tanto para o bem como para o mal - senão à escala individual. Nietzsche agia sobre seus leitores; um leitor nietzschiano que se torna autor tem apenas uma ação irrisória. Mas, a partir do momento em que o homem se apodera efetivamente dos poderes da matéria, quando já não sonha com elementos intangíveis ou átomos curvos, mas organiza realmente novos corpos e comanda forças reais, ele chega à vontade de poder dotada de uma verificação objetiva. Transforma-se num mágico verdadeiro, demônio positivo. E ensina uma magia verdadeira. Enriquece o futuro conferindo-lhe uma vontade de poder provada. Por isso mesmo, a ligação da vontade de poder com a vontade de saber torna-se estreita e duradoura. Esta ligação inscreve-se no futuro do homem. ${ }^{32}$

Pouco antes, em 1951, no livro L'activité rationaliste de la physique contemporaine, Bachelard apresentou seu novo e ambicioso programa para a filosofia das ciências:

Objetividade racional, objetividade técnica, objetividade social são doravante três características fortemente ligadas. Se esquecemos apenas uma dessas

\footnotetext{
${ }^{30}$ BOWKER e LATOUR, "A booming discipline short of discipline: (Social) Studies of Science in France”, p. 723.

${ }^{31}$ BACHELARD, Le matérialisme rationnel, p. 40-41.

${ }^{32}$ Idem.
} 
características da cultura científica moderna, entramos no domínio da utopia. Uma filosofia das ciências que não quer ser utópica deve tentar formular uma síntese dessas três características. Em particular, é sem dúvida a ela que pertence a tarefa de mostrar a importância do caráter intersubjetivo, do caráter histórico e social, em reação mesmo contra os próprios hábitos do pensamento filosófico. ${ }^{33}$

Impressiona a aproximação com as ideias de Fleck, que, em 1934, já reconhecia que "pelo menos três quartos, talvez a totalidade do conteúdo das ciências, são condicionados e podem ser explicados pela história do pensamento, pela psicologia e pela sociologia do conhecimento"34. Porém, pela escolha dos objetos de investigação, são sem dúvida mais impressionantes as semelhanças entre Fleck e Canguilhem. Vale a pena ler em sequência esses dois comentário sobre a função cognitiva do social, o primeiro encontrado no artigo "Thérapeutique, expérimentation, responsabilité", de Canguilhem: "A medicina, assim como qualquer outra forma de atividade técnica, é hoje um fenômeno à escala das sociedades industriais, escolhas de caráter político se encontram implicadas em todos os debates concernentes às relações do homem com a medicina."35 Para Canguilhem, essa implicação do político sobre o pensamento médico está longe de ser um elemento unicamente negativo, mesmo no caso das ideologias médicas. Ela diz respeito, antes, à própria forma de elaboração do conhecimento e da prática médica nas sociedades contemporâneas. Nada diferente do que pensa Fleck: "Aquele que considera o contexto social como um malum necessarium, como uma insuficiência infelizmente constitutiva do gênero humano e contra o qual se deve combater, ele ignora que não existe verdadeiramente que nenhum ato cognitivo é possível sem fator social."36

Num artigo recente publicado na revista Intelligere, inicialmente texto de uma conferência apresentada durante o evento "Os objetos da história das ciências", Condé considera não ser mera coincidência o fato de que Fleck e Canguilhem, de maneira completamente independente, tenham formulado suas epistemologias a partir de uma reflexão sobre a medicina, estranha à racionalização prometida pelas ciências mais "clássicas" que serviram de modelo às teorias do conhecimento. Seja pela irredutibilidade da vida aos fenômenos físico-químicos do organismo ou pela relação inextrincável entre a terapêutica e os aspectos sociais, culturais e históricos de uma sociedade específica, é pela própria natureza do objeto de suas reflexões que, segundo Condé, Canguilhem e Fleck contribuíram decisivamente para a "formulação das bases de uma epistemologia histórica que se consolidará ao longo do século XX estabelecendo um novo

\footnotetext{
${ }^{33} \mathrm{BACHELARD}, L$ 'Activité rationaliste de la physique contemporaine, $\mathrm{p} .10$.

${ }^{34}$ FLECK, Gênese e desenvolvimento de um fato científico, p. 62.

${ }^{35}$ CANGUILHEM, "Thérapeutique, expérimentation, responsabilité", p. 383-384.

${ }^{36}$ FLECK, Op.cit., p. 36.
} 
estilo de pensamento para a compreensão da história da ciência"37.

O tema já havia sido explorado por Jean-Fraçois Braunstein no artigo "Deux philosophies de la médecine: Canguilhem e Fleck", no qual são apontadas semelhanças espantosas entre suas teses epistemológicas. "Essas similitudes dizem respeito aos pontos centrais de suas filosofias, quer se trate de suas respectivas críticas das teorias do conhecimento, de suas concepções de história das ciências, da questão das relações entre ciência e não-ciência ou mesmo da questão da verdade", escreveu ${ }^{38}$. Braunstein chega a falar em um "air de famille" entre Canguilhem e Fleck a partir de pontos fundamentais das suas epistemologias: o papel da história das ciências na crítica da teoria do conhecimento, as relações entre ciência e sociedade, até mesmo o questionamento sobre a fundamentação da verdade científica ${ }^{39}$. Assim como Canguilhem, foram preocupações de epistemólogo que levaram Fleck à história das ciências. Embora o título do seu grande livro possa sugerir um trabalho eminentemente histórico, Fleck não hesita em apresentar Gênese e desenvolvimento de um fato científico como "um estudo epistemológico" 40 no qual a crítica à teoria do conhecimento é realizada através da história das ciências. Braunstein chama atenção para o fato de que, nesse livro, Fleck apresenta um capítulo inicial sobre o surgimento e a história do conceito atual de sífilis para, no capítulo seguinte, investigar as "Consequências para a teoria do conhecimento da história apresentada de um conceito"; ele discorre sobre a descoberta da reação de Wassermann para, em seguida, propor um capítulo sobre os "Aspectos epistemológicos da história da reação de Wassermann”, indicando que, na obra maior de Fleck, a história das ciências aparece como uma etapa necessária da investigação epistemológica.

É preciso lembrar que o livro de Fleck começa com uma pergunta desconcertante, que problematiza aquilo que tomamos por óbvio e quase natural: “O que é um fato?”. Em Gênese $e$ desenvolvimento de um fato científico, o alvo de Fleck é justamente a noção do fato como sendo a correspondência lógica entre a proposição e o dado, o fato "descoberto" e cuja verdade é legitimada pela sua evidência. Ao invés disso, Fleck propõe o fato científico construído ${ }^{41}$, sobre o qual só podemos nos informar a partir da sua historicidade intrínseca: "não se chega a um conceito de sífilis sem uma abordagem histórica”, afirma Fleck ${ }^{42}$. Para ele, essa historicidade necessária à ciência exige uma revisão de toda teoria do conhecimento que se apresente como

${ }^{37} C f$. CONDÉ, Mauro Lucio Leitão. "Entre o normal e o patológico: Ludwik Fleck, Georges Canguilhem e a gênese da epistemologia histórica". Intelligere, v. 2, n. 1, p. 51-67, maio 2016.

${ }^{38}$ Cf. BRAUNSTEIN, Jean-François. "Deux philosophies de la médecine: Canguilhem et Fleck", p. 64.

${ }^{39}$ BRAUNSTEIN, Loc. cit.

${ }^{40}$ FLECK, Gênese e desenvolvimento de um fato científico, Prefácio.

${ }^{41}$ Ibidem, p. 132:

${ }^{42}$ Ibidem, p. 62. 
mera "crítica aos métodos para se chegar ao fato" ${ }^{43}$ :

Podemos definir o fato científico provisoriamente como uma relação de conceitos conforme o estilo de pensamento, que, embora possa ser investigável por meio dos pontos de vista históricos e psicologia individual e coletiva, nunca poderá ser simplesmente construída, em sua totalidade, por meio desses pontos de vista. ${ }^{44}$

Para Fleck, a atenção à prática real das ciências - que ele mesmo experimentou em sua atuante carreira como médico e microbiologista - exige uma teoria do conhecimento que não se limite à busca por legitimação, com provas objetivas e construções lógicas, de um fato científico, mas que assuma a tarefa de estabelecer os vínculos históricos que presidem a construção dos fatos científicos: "qualquer teoria do conhecimento sem estudos históricos ou comparados permaneceria um jogo de palavras vazio, uma epistemologia imaginária (Epistemologia imaginabilis)”, sentenciou ${ }^{45}$. Impressiona a semelhança com o pensamento de Canguilhem, para quem o interesse pela história das ciências é uma vocação da epistemologia, que, de fato, sempre foi histórica: "No momento em que a teoria do conhecimento deixou de ser fundada sobre uma ontologia, incapaz de dar conta das novas referências adotadas pelos novos sistemas cosmológicos, é nos próprios atos de saber que devemos buscar não sua razão de ser, mas seus meios de se tornar"

O reconhecimento de diferentes formas de racionalidade científicas, apreendidas na especificidade histórica de cada ciência particular, ajudou a libertar historiadores e epistemólogos dos modelos de cientificidade físico e matemático que, desde Kant, deveriam guiar todas as ciências. $\mathrm{O}$ fato de que Canguilhem tenha se dedicado às ciências da vida e valorizado o papel do vitalismo na história da biologia, contra as teorias reducionistas do orgânico a fenômenos físicoquímicos, pode ser entendido como uma reação à pretensão das teorias clássicas do conhecimento em fundar uma "ciência da ciência", uma ciência situada fora das ciências, mas de onde pretenderia determinar as regras do conhecimento científico. Afinal, é nesse ponto que se observa mais claramente o pressuposto idealista do positivismo, isto é, na pretensão de isolar uma essência comum a todas as ciências que permita falar do conhecimento científico como um todo, a fim de elaborar uma teoria do conhecimento unitária, em vez de procurar as condições histórico-epistemológicas que determinam a construção das verdades e dos fatos científicos no interior de cada disciplina. Aí, conforme Dominique Lecourt, pouco importa se, como na filosofia

\footnotetext{
${ }^{43}$ Ibidem, Prefácio.

${ }^{44}$ Ibidem, p. 62.

${ }^{45}$ Idem.

${ }^{46}$ CANGUILHEM, "Le rôle de l'épistémologie dans l'historiographie scientifique contemporaine”, p. 20.
} 
idealista, uma ciência particular (a Física ou a Matemática) é encarregada de fornecer as categorias, ou, como no positivismo lógico, se faça da epistemologia "uma espécie de 'encruzilhada', onde uma série de disciplinas heteróclitas com pretensão científica vêm conjugar seus conceitos discordantes, a fim de constituir uma teoria geral das ciências". ${ }^{47}$ Por isso Fleck, em Gênese e desenvolvimento de um fato cientifico, criticava "a visão particularmente ingênua" de Carnap, de Schlick e do Círculo de Viena, "esses teóricos do conhecimento formados nas ciências exatas", para quem "a teoria do conhecimento não visaria à descoberta dos vínculos históricos, mas à sua legitimação científica, a provas objetivas e construções lógicas"48. Enquanto Canguilhem, em La formation du concept de reflèxe, zombava da "segurança, dada pela filosofia analítica da ciência, de que a ciência chegou agora à sua maturidade, que o modelo lógico dos novos resultados por vir permanecesse aquilo que ele é": nesse cenário, diz Canguilhem, "o trabalho do historiador, munido de um tipo acabado de teoria, consistiria em solicitar às teorias do passado as razões de sua falta de maturidade lógica"49.

\section{Objetividade e historicidade do pensamento científico}

O primeiro capítulo da nossa tese foi dedicado à tarefa de mostrar como se difundiu a imagem de Canguilhem como um filósofo fundamentalmente interessado pela história das ciências. Segundo os críticos dessa imagem, dentre os quais destacamos Camille Limoges, em função do seu papel atual na organização dos arquivos e na publicação da obra completa de Canguilhem, foi sobretudo o grupo de filósofos marxistas reunidos em torno de Louis Althusser o responsável pela difusão dessa ideia. Mostramos também que foi graças a um ex-aluno de Althusser e Canguilhem, Dominique Lecourt, que a expressão "epistemologia histórica" ganhou audiência fora da França, acompanhando as várias traduções da sua dissertação de mestrado sobre "a epistemologia histórica de Gaston Bachelard" - título mantido apesar das objeções do seu orientador, Canguilhem, que preferia a expressão "história epistemológica".

$\mathrm{Na}$ entrevista que realizamos com Jean-François Braunstein, publicada no dossiê da revista Intelligere sobre a obra de Georges Canguilhem, questionamos as razões que explicariam o ocaso da epistemologia histórica na França. Segundo Braunstein, a primeira razão foi justamente aquela apropriação de Canguilhem pelos althusserianos, até o limite da confusão da sua obra com uma espécie de althusserismo sem Marx. Quando se parou de associar o nome de

\footnotetext{
${ }^{47}$ LECOURT, Pour une critique de l'épistémologie, p. 09.

${ }^{48}$ FLECK, op. cit, p. 62.

${ }^{49}$ CANGUILHEM, La formation du concept de reflèxe..., p. 156-157.
} 
Canguilhem ao de Althusser, alguns entulhos, como a descontinuidade radical entre ciência e não-ciência (seja ela de origem ideológica, filosófica ou até mítica), já haviam se transformado em vulgata da epistemologia histórica, às vezes por erro honesto, outras por maledicência programática (Latour se presta a esse papel). A segunda razão para o que Braunstein chamou de “interrupção brutal" da epistemologia histórica em solo francês, "à parte um ou dois sobreviventes isolados, como François Delaporte ou pessoas mais jovens como Pierre-Henri Castel”, foi, pasmem, “o lado provinciano da França”. Braunstein explica:

No momento em que as filosofias analíticas da ciência começavam a se esmigalhar e até mesmo a desaparecer nos Estados Unidos, nós aqui dissemos: "é preciso absolutamente importá-las na França". Logo, tentou-se erradicar a história das ciências à francesa dos estabelecimentos em que ela era praticada. É bastante curioso e irônico de ver: no mesmo momento em que a epistemologia se tornava histórica novamente em toda parte do mundo, na França ela não deveria mais fazer história das ciências. Lembro-me de uma anedota da época em que eu ainda estava no Institut d'histoire des sciences... Eu tinha ido falar de Canguilhem na London School of Economics, e quando voltei me disseram: "Você não tem vergonha de dar essa imagem do Institut d'histoire des sciences? Nós teremos ar de quê no exterior se pensarem que ainda pesquisamos Canguilhem?". Ao passo que era evidentemente o que as pessoas da London School of Economics queriam... ${ }^{50}$

Em 1996, Roger Guesnerie e François Hartog organizaram, na École des hautes études en siences sociales, em Paris, um seminário intitulado "Études sur les sciences, Études sur les techniques". O objetivo desse encontro, dizem seus organizadores, era ouvir de alguns especialistas em história das ciências e das técnicas quais seriam os pontos mais vivos dos debates em curso naquelas disciplinas. Participaram do seminário cerca de trinta pesquisadores, entre palestrantes e debatedores, incluindo nomes bastante conhecidos dos pesquisadores brasileiros nessas áreas, como Dominique Pestre, Fernando Gil, Roger Chartier, Bruno Latour e Yves Cohen. Atravessando todas as falas, duas ideias eram recorrentes: a "crise" da história das ciências e das técnicas (particularmente na França), mas também a sua "recomposição", agora a partir de uma "reconfiguração" dos problemas tradicionalmente abordados. Os títulos das mesas, como, "História intelectual e sociologia das ciências", "Cognição, tradições científicas e culturas", "Epistemologia e história social" ou "Técnica e cultura material”, dão pistas dos novos elementos dessa configuração. Foi na mesa "História da objetividade científica" que Lorraine Daston apresentou pela primeira vez de modo sistemático o "programa historiográfico" que chamou de "epistemologia histórica", naquela ocasião, ainda considerado um programa "muito

${ }^{50}$ ALMEIDA e CAMOLEZI, “Entretien avec Jean-François Braunstein”, p. 162. 
jovem e que ainda não deu provas suficientes de que possa ser qualificado como uma escola”.

Aquilo que eu entendo por historical epistemology é a história das categorias que estruturam nosso pensamento, que modelam nossa concepção da argumentação e da prova, que organizam nossas práticas, que certificam nossas formas de explicação e que dotam cada uma dessas atividades de uma significação simbólica e de um valor afetivo. Essa epistemologia histórica pode (e, de fato, ela deve) reenviar a uma história das ideias e das práticas, tanto quanto à história das significações e dos valores que constituem as economias morais das ciências. Mas ela põe questões de tipo diferente: (...) não o julgamento histórico segundo o qual tal ou tal disciplina atingiu a objetividade e, caso sim, quando e como, mas antes uma exploração histórica das múltiplas significações e manifestações científicas da objetividade. ${ }^{51}$

Daston não ignorava a situação: "tenho consciência de que o termo 'épistémologie historique' recebeu no passado uma significação bem diferente em francês, na continuidade do trabalho de Bachelard". Por isso, mesmo falando em francês, manteve o termo em sua versão inglesa, historical epistemology, "seguindo a denominação que esse programa recebeu nos círculos anglófonos ou germanófonos" ${ }^{, 52}$.

Em 2010, Yves Gingras publicou um artigo intitulado "Naming without necessity: on the genealogy and uses of the label "historical epistemology"" ["Nomeando sem necessidade: sobre a genealogia e usos do rótulo 'epistemologia histórica"'], no qual se diz surpreso pelo crescente interesse, fora da França, pela questão “O que é a epistemologia histórica?”, ele diz, "como se houvesse uma substância (o que é) a ser encontrada por trás dessas palavras" Interesse, diz Gingras, manifesto numa série de conferências e mesmo em publicações especializadas, sob o formato de dossiês, sobretudo no mundo anglo-saxão. Surpresa talvez injustificada, pois, segundo Mary Tiles, autora do livro Bachelard: Science and Objectivity, o resgate nos países de língua inglesa dessa tradição francesa que estudamos começou como uma busca por um antídoto contra a ameaça de irracionalismo implícita na teoria da incomensurabilidade. Para Tiles, Bachelard foi redescoberto como "o filósofo da ciência que aparentemente tinha resolvido esse problema" e esse resgate só foi possível porque, embora Bachelard seja reconhecido como o grande pensador da descontinuidade na história das ciências, ele não apenas não vê a descontinuidade como "uma ameaça à possibilidade de racionalidade ou objetividade na ciência, como também a compreende como um produto do processo racional do

\footnotetext{
${ }^{51}$ DASTON, “Une histoire de l'objetivité scientifique”, p. 118.

${ }^{52}$ Idem.

${ }^{53}$ GINGRAS, "Naming without necessity: on the genealogy and uses of the label 'historical epistemology", p. 1.
} 
avanço da ciência",54.

O motivo da grande repercussão causada pelo artigo de Gingras é que seu autor propõe que essa designação, "epistemologia histórica", é o mero produto de um processo de branding, isso é, a criação de um rótulo para introdução de uma marca no mercado das ideias uma marca que facilitaria a organização de eventos, o lançamento de livros, a publicação de dossiês etc. Gingras chama atenção para o fato de que num intervalo de poucos meses duas grandes conferências haviam sido organizadas em torno da questão "O que é epistemologia histórica?": a primeira no Max Planck Institute for the History of Science, em Berlim, e a segunda na Columbia University, na qual ele mesmo apresentou a versão original do texto que deu origem ao artigo mencionado. Como contribuição aos debates realizados na Columbia University, Gingras propôs uma "genealogia" do rótulo epistemologia histórica. Afirmou que seu primeiro emprego foi registrado naquela dissertação de mestrado de Dominique Lecourt e que, desde então, "epistemologia histórica" é uma expressão utilizada para designar a filosofia de Bachelard e seus discípulos (entenda-se Canguilhem e seus alunos), de tal maneira que seu sentido nunca foi problematizado. Para Gingras, a pergunta “o que é a epistemologia histórica?" nunca havia sido de fato feita na França, já que a expressão teria o sentido evidente de delimitação de uma tradição.

Para Gingras, a razão que justifica a escolha e o sucesso da expressão “epistemologia histórica" em vez daquela proposta por Canguilhem, "história epistemológica", estaria relacionada à sua utilização pela filosofia marxista. Além do próprio livro de Lecourt, Gingras identificou outros dois trabalhos produzidos por filósofos marxistas de maneira aparentemente independente que utilizavam a expressão "epistemologia histórica": um artigo de Marx Wartofsky publicado em 1973, "Perception, representation and the forms of action: towards an historical epistemology", e o livro "Problems in Historical Epistemology", publicado na Polônia por Jerzy Kmita em 1980 e traduzido para o inglês em 1988. Mas a chave para a interpretação de Gingras foi encontrada numa tradução para o inglês, publicada em 1972, do livro Pour une critique de l'épistémologie, de Dominique Lecourt. Lançado nos Estados Unidos sob o título Marxism and Epistemology: Bachelard, Canguilhem and Foucault, o livro de Lecourt é uma coletânea de textos entre os quais figura, por exemplo, aquele prefácio escrito para a tradução argentina de $O$ normal e o patológico (uma tradução em português desse livro, chamada Para uma crítica da epistemologia, foi publicada em Lisboa, também em 1972, pela editora Assírio e Alvim). Do fato que o primeiro artigo do livro tem por título "De Bachelard ao materialismo histórico", Gingras deduziu que a expressão “epistemologia histórica” era o equivalente a uma

\footnotetext{
${ }^{54}$ TILES, Bachelard: Science and Objectivity, Prefácio, xv
} 
intervenção marxista no campo da filosofia das ciências. "Materialismo histórico", logo, “epistemologia histórica”.

Deduziu também que "epistemologia histórica" é uma filosofia com ênfase histórica e não uma forma de fazer história das ciências. Por isso ela era bem adequada para falar dos trabalhos de Bachelard, enquanto Canguilhem e seus discípulos deveriam preferir "história epistemológica". Também por essa razão, Gingras afirmou que é o rótulo errado para o tipo de pesquisa realizada por Lorraine Daston no recém-criado Max Planck Institute. Num texto programático de 1994, Daston afirma que considera "epistemologia histórica" o melhor rótulo para seu trabalho, que consistia em "entender a história das categorias que estruturam nosso pensamento, normatizam nossos argumentos e provas e certificam nossos padrões de explanação",55. Assim, para Gingras, o que Daston propõe seria melhor qualificado como uma epistemologia historicizada, pois no Max Planck Institute, o esforço estaria voltado para a historicização das nossas categorias de pensamento, e não para a epistemologização da história. Assim, como, em sua opinião, se trataria simplesmente de apreender historicamente todas as palavras, categorias e conceitos relacionados ao pensamento científico, algo que, nos dias atuais, deveria ser um dado evidente para qualquer um que se disponha refletir seriamente sobre as ciências, Gingras conclui que os pesquisadores do Max Planck Institute "nomeiam sem necessidade". Propõe, assim, que abandonemos o rótulo "epistemologia histórica" e concordemos que se trata, pura e simplesmente, de algo que pode ser chamado de "uma boa história das ciências", isto é, "uma história fiel aos preceitos do método histórico".

Por mais interessante - e até divertida - que a provocação feita por Gingras possa ser, não podemos deixar de notar quão a-histórica e superficial é essa sociologia do conhecimento, mais preocupada com o rótulo que com seu conteúdo. O pouco de história que há em sua análise incorre em um erro primário de verificação das fontes. A analogia, mal disfarçada de história dos textos, que Gingras propõe entre "materialismo histórico" e "epistemologia histórica" só é possível porque ele acredita que esse rótulo foi uma invenção de Dominique Lecourt. Porém, o registro mais antigo da expressão foi feito por Abel Rey em 1907, no livro La théorie de la physique chez les physiciens contemporains, originalmente sua tese de doutorado. Rey explica que "epistemologia", então um neologismo na França, é o modo como a filosofia americana se refere ao tipo de "investigação transcendente sobre os princípios gerais e condições das ciências". A fim de delimitar seu livro desse tipo de investigação, Rey explica que

(...) essa palavra [epistemologia], restrita a um significado positivo, pode de bom grado se referir à pesquisa dos documentos, ao conjunto de observações

${ }^{55}$ DASTON, "Historical Epistemology”, p. 282 
históricas necessárias para o estabelecimento de uma visão exata das diferentes ciências, uma ciência positiva das ciências. E a pesquisa histórica concernente ao espírito geral de cada ciência se constituiria, assim, como uma das grandes seções da epistemologia histórica. (...) O que eu proponho fazer aqui em primeiro lugar é precisamente uma contribuição a essas pesquisas históricas relativas ao espírito científico. (...) Farei um trabalho de historiador, mas de historiador consciente dos serviços que uma lógica positiva poderia tirar da história das ciências. Jamais perderei de vista a finalidade metodológica para a qual essa história pode contribuir. ${ }^{56}$

Não se trata de um dado episódico. Em 1932, Abel Rey fundou e assumiu a presidência do Institut d'histoire des sciences de l'Université de Paris, no ano seguinte rebatizado de Institut d'histoire des sciences et des techniques. Rey presidiu o Institut até 1940, sendo sucedido nesse cargo por Gaston Bachelard até 1955, quando a cadeira da presidência passou a ser ocupada por Canguilhem. Em 1934, no primeiro número de Thalès, periódico publicado pelo Institut, Rey definiu a epistemologia histórica como programa, contra aquela ideia de “investigação transcendente" sobre os princípios científicos ${ }^{57}$. "A teoria do conhecimento, sem uma história filosófica das ciências, é apenas uma vaga ideologia ou uma dialética verbal", afirmou. Para Rey, via a história filosófica das ciências, a história das ciências deixa de ser "um simples trabalho de erudição".

Esse debate, curiosamente chamado de "epistemologia histórica old e new schools" pelos círculos de pesquisadores estrangeiros que se dirigem à França para estudar as obras de Bachelard e Canguilhem, não teve início quando Lorraine Daston apresentou seu programa para o público francês em 1996, mas três anos antes, quando Ian Hacking reuniu em Montréal jovens pesquisadores e professores de universidades de Chicago, Paris e Toronto para uma semana inteira de discussões dedicadas à "epistemologia histórica". Já naquela ocasião, ele foi criticado por seu colega de departamento Yves Gingras, que o advertira sobre a inconveniência do rótulo, dado o sentido a ele atribuído na França na primeira metade do século passado. Hacking respondeu que esse era um problema menor, que a ideia de Bachelard diferia radicalmente daquilo que Lorraine Daston propunha sob o nome de epistemologia histórica. Para Hacking, Bachelard "insiste que considerações históricas são essenciais para a prática da epistemologia", enquanto para Daston trata-se de examinar "as trajetórias de objetos que desempenham um certo papel na reflexão sobre conhecimento e crença" ${ }^{, 58}$. Segundo Hacking, Daston e seus colegas no Max Planck Institute "não fazem epistemologia. (...) Eles estudam conceitos epistemológicos que

\footnotetext{
${ }^{56}$ REY, La théorie de la physique chez les physiciens contemporains, p. 13.

${ }^{57}$ REY, 'L'Institut d'histoire des sciences et des techniques de l'université de Paris", p. V.

${ }^{58}$ HACKING, Historical ontology, p. 9-10.
} 
evoluem e mudam. Seu trabalho receberia um nome mais fiel se fosse chamado de metaepistemologia histórica”. Em suma, para Hacking, a diferença fundamental consistiria no fato de que, à diferença de Bachelard, Daston e seus colegas meta-epistemólogos históricos "não propõem, não advogam ou refutam teorias do conhecimento".

Ora, parece-nos que, quando Hacking traça na relação com a teoria do conhecimento a linha divisória entre a antiga e a nova escola epistemologia histórica, ele ignora o fato de que a epistemologia histórica, ao menos na França, já possui uma história e que, como nos esforçamos para demonstrar, ela não se resume à obra de Bachelard. Para usar uma bela imagem de Bachelard sobre as "origens" do pensamento científico, podemos dizer que a origem bachelardiana da epistemologia histórica é um ponto geográfico importante, mas que não contém a força viva do rio. Como diz Braunstein, embora, de fato, a epistemologia histórica francesa seja mais filosófica, enquanto a alemã é mais histórica, "no fundo, porém, há uma inspiração comum"59. Quando se considera a obra de Canguilhem, percebe-se "o mesmo gênero de problemática". Na França e na Alemanha, "trata-se de ver como noções meta-teóricas, metaepistemológicas, digamos, como a objetividade, são noções que têm uma história”. Se escrever a história da objetividade é a atividade principal dos pesquisadores do Max Planck Institute for the History of Science, o reconhecimento da historicidade da objetividade é a base da teoria da história das ciências desenvolvida no Institut d'Histoire des sciences et des techniques.

Segundo Foucault, a epistemologia, no método de Canguilhem, se apresenta como “uma reflexão teórica indispensável que permite à história das ciências constituir-se de uma maneira diferente da história em geral", ao mesmo tempo em que a história das ciências "abre o domínio da análise indispensável para que a epistemologia seja outra coisa que a simples reprodução dos esquemas internos de uma ciência em um dado momento". ${ }^{60}$ Nas palavras do próprio Canguilhem:

o historiador e o epistemólogo têm em comum (ou, pelo menos, deveriam ter em comum) a cultura científica de hoje. Mas, situando-a diferentemente em suas perspectivas, eles lhe conferem uma função histórica diferente. O historiador procede das origens para o presente, de forma que a ciência de hoje é sempre anunciada em certa medida pelo passado. O epistemólogo procede do atual para os seus começos, de forma que apenas uma parte daquilo que se tomou ontem por ciência se encontra em certa medida fundada pelo presente. Ora, ao mesmo tempo em que ela funda - nunca, seja bem entendido, para sempre, mas incessantemente de maneira diferente - a ciência de hoje também destrói, e para sempre. $^{61}$

\footnotetext{
${ }^{59}$ ALMEIDA e CAMOLEZI, "Entretien avec Jean-François Braunstein”, p. 161.

${ }^{60}$ FOUCAULT, "A vida: a experiência e a ciência", p. 361.

${ }^{61}$ CANGUILHEM, "L’histoire des sciences dans l'œuvre épistémologique de Gaston Bachelard”, p. 178-179.
} 
Sem recurso à epistemologia, diz Canguilhem, uma história das ciências estaria condenada a "reduzir uma dada ciência, num dado momento, (...) a uma exposição das relações cronológicas e lógicas entre diferentes sistemas de enunciados relativos a algumas espécies de problemas e soluções",62, quer dizer, ela seria obrigada a seguir a elaboração das teorias científicas como um processo de resolução de problemas criados por uma teoria anterior. Assim, a história de uma ciência estaria limitada ao domínio de exploração determinado pelos cientistas de uma determinada época, de tal maneira que o valor de um historiador, diz Canguilhem, "seria medido pela amplitude da erudição e pela sutileza da análise das relações, analogias ou diferenças estabelecidas entre os cientistas".

Fazer a história das ciências como a história da anterioridade, da simultaneidade e da sucessão, das descobertas e das influências, para Canguilhem, seria não diferenciar as ciências de qualquer outro aspecto da cultura. Ela seria menos história e mais memória, posto que reduziria, por exemplo, a história da botânica no século XVIII à história daquilo que os botânicos da época designaram como seu campo de investigação. O que Canguilhem propõe, em vez disso, é que o passado de uma ciência atual jamais seja confundido com essa mesma ciência no seu passado.

\begin{abstract}
Nesse sentido, o passado da atual fisiologia vegetal [por exemplo] compreenderia tudo o que as pessoas a que chamamos de botânicos, médicos, químicos, horticultores, agrônomos, economistas escreveram sobre as suas conjecturas, observações ou sobre experiências quanto às relações entre estrutura e função, sobre objetos designados por ervas, plantas ou vegetais. Ainda que, de fato, se trate de uma biblioteca ideal, esta é idealmente, de direito, a integralidade de uma soma de recordações. A totalidade do passado está aí representada como uma espécie de plano contínuo dado, a partir do qual se pode deslocar, segundo o interesse do momento, o ponto de partida do progresso cujo termo é precisamente o objeto atual desse interesse. O que distingue os historiadores das ciências entre si é a temeridade ou a prudência com que praticam os seus deslocamentos a partir deste plano. ${ }^{63}$
\end{abstract}

Nesse ponto, Canguilhem concorda com a epistemóloga e historiadora da matemática Suzanne Bachelard (filha de Gaston Bachelard), para quem "o historiador das ciências constrói o seu objeto num espaço-tempo ideal. Cabe a ele evitar que este espaço-tempo seja imaginário”. $\mathrm{Ou}$, nas palavras do próprio Canguilhem, "o que a história das ciências tem o direito de esperar da epistemologia é uma deontologia da liberdade de deslocação regressiva sobre o plano

\footnotetext{
${ }^{62}$ CANGUILHEM, "Le rôle de l'épistémologie dans l'historiographie scientifique contemporaine”, p. 13.

${ }^{63}$ Ibidem, p. 14.
} 
imaginário do passado integral" ${ }^{\prime 64}$. Num texto menos conhecido, ainda pouco acessível (provavelmente será publicado no último tomo das obras completas de Canguilhem, previsto para 2018), Canguilhem utilizou o termo "estruturalismo" para falar da idealidade espaço-temporal dessa biblioteca sobre a qual o historiador deve se deslocar. No auge da onda estruturalista, em 1967-1968, a revista Raison présente - fundada pelo militante do Partido Comunista Francês Victor Leduc - organizou uma série de encontros, com importantes intelectuais franceses, em torno do tema "As estruturas e os homens". Em 27 de fevereiro de 1968, Canguilhem participou de uma mesa intitulada "Objetividade e historicidade do pensamento científico". Yves Galifret, coordenador da atividade, apresentou o problema nos seguintes termos: "a ciência nasce de um logos característico de uma época, da épistemê de uma época, ou existe um saber cumulativo que cresce, que se modifica, mas que dura, que manifesta uma certa permanência?". ${ }^{65}$

Ao falar de épistemê, Galifret deixa claro que o problema está colocado a partir da obra de Michel Foucault, mais especificamente, do livro As palavras e as coisas, de1966. Investigando as condições de possibilidade dos enunciados científicos, Foucault identificou estratégias distintas para cada grande período do pensamento. Assim, por exemplo, localizou a Semelhança no período da Renascença e a Representação na Modernidade Clássica. Já a partir do século XIX, com o rompimento do espaço da Representação (primeiramente com a Crítica kantiana, argumenta Foucault), os Objetos viram-se libertados dos Sujeitos e passaram a ser ordenados entre si a partir da sua própria história, até o ponto em que o próprio Sujeito foi percebido como evento, o resultado da articulação desses seres empíricos. Em Arqueologia do saber, livro de método publicado em 1969, Foucault explica que havia pensado aquele problema das épistemês a partir do que chamou de "a priori histórico". Foucault é o primeiro a reconhecer o estranhamento causado pela associação entre "a priori" e "história", mas sustentou a aplicação nessa nova formulação metodológica:

(...) quero designar um a priori que não seria condição de validade para juízos, mas condição de realidade para enunciados. Não se trata de reencontrar o que poderia tornar legítima uma assertiva, mas isolar as condições de emergência dos enunciados, a lei de sua coexistência com outros, a forma específica de seu modo de ser, os princípios segundo os quais subsistem, se transformam e desaparecem. A priori, não de verdades que poderiam nunca ser ditas, nem realmente apresentadas à experiência; mas de uma história determinada, já que é a das coisas efetivamente ditas. ${ }^{66}$

Conhecedor privilegiado dessa proposta metodológica de Foucault, Canguilhem, que

\footnotetext{
${ }^{64}$ Ibidem, p. 15.

${ }^{65}$ LEDUC et al. Structuralisme et marxisme, p. 204.

${ }^{66}$ FOUCAULT, A Arqueologia do Saber, p. 146.
} 
foi seu interlocutor durante a redação daqueles livros, defendeu que essa teoria, que apenas a contragosto aceita chamar de "estruturalista", é o único modo de explicar aquilo que chamamos de "crises", "rupturas" ou "revoluções" do saber. Isso porque, para Canguilhem, essa abordagem proposta por Foucault a partir do termo épistemê e do conceito de a priori histórico apenas evidencia que a objetividade de uma ciência ou de um determinado conceito científico não pode ser determinada sem levar em consideração "o conjunto de interseções que constituem um modo comum e coletivo de pensar" ${ }^{\prime 67}$. Embora não esconda sua repugnância pelo termo “estruturalismo" - em sua opinião, um termo "vazio", que "não significa nada", e, insulto dos insultos, "um conceito de jornalista" - Canguilhem afirma que é apenas por essa perspectiva dita estruturalista que podemos conceber, no interior de uma história das ciências, a especificidade própria da objetividade das ciências.

Essa abordagem estruturalista, na opinião de Canguilhem, representa uma forma de historicização radical, pois resolve o problema da relação entre a objetividade científica e a historicidade do saber a partir da historicização da própria objetividade. Quer dizer, a objetividade aparece como um modo coletivo de pensamento que, em uma determinada época, estrutura as formas de enunciação e estabelecimento de provas para qualquer discurso que se pretenda científico. E essa objetividade, diz Canguilhem, é definida não a priori por uma teoria do conhecimento, mas - reencontramos o caminho da epistemologia histórica - na própria historicidade daqueles discursos:

A objetividade é, portanto, em um domínio científico dado, definida progressivamente nas suas condições efetivas, definida progressivamente pelas próprias ciências. Dizer das condições de objetividade - que elas sejam teóricas, experimentais ou ainda inseparavelmente teóricas e experimentais -, dizer que elas são definidas progressivamente é, então, reconhecer à ciência uma historicidade que a constitui enquanto ciência. Uma ciência que não tem história, quer dizer, uma ciência não qual não há recusa de certas condições de objetividade, em um dado momento, e substituição de condições de objetividade mais objetivamente definidas, uma disciplina assim concebida não é uma ciência. A característica própria das falsas ciências (...) é que elas não tem história, e a partir do momento que elas não tem história, é indicativo suficiente de que elas não pretendem à objetividade. ${ }^{68}$

Se Canguilhem pode falar de uma historicidade progressiva, não é porque assumiu o valor de abstração que Bachelard pôde usar para julgamento da Física e da Química, mas porque adotou a perspectiva segundo a qual o progresso é a passagem de um valor a outro, isto é, de um

\footnotetext{
${ }^{67}$ CANGUILHEM et al. "Objectivité et historicité de la pensée scientifique”, p 234.

${ }^{68}$ Ibidem, p 234.
} 
valor de objetividade a outro. Portanto, conclui Canguilhem, "não há incompatibilidade a priori entre a introdução, na história das ciências, de uma certa visão de coerências ou de estruturas na mentalidade científica de uma época, e o reconhecimento da objetividade do saber em um momento histórico dado" ${ }^{\prime 69}$. E, assim como acontece com a história dos conceitos biológicos, cuja objetividade, mostramos a propósito do conceito de reflexo, exige a investigação sobre a sua inclusão numa prática terapêutica, Canguilhem não foge do questionamento sobre a aplicabilidade desse modelo de história da objetividade científica às técnicas da vida, em especial a uma prática social, como é a medicina nas sociedades modernas. E, mais uma vez, recorre às reflexões de Foucault para falar sobre a história estrutural das condições de objetividade teóricas e experimentais que garantiriam a cientificidade a determinada prática médica.

O problema da execução de um novo olhar médico por uma nova estrutura hospitalar não é um problema. Michel Foucault o abordou para o domínio francês. Na verdade, o domínio é europeu. A transformação simultânea da clínica e do tratamento dos doentes em estabelecimentos especializados, isso não concerne apenas à França, e é aí que podemos dizer, que em uma época dada, existe uma estrutura ao mesmo tempo indissoluvelmente prática e teórica do olhar que a sociedade lança sobre a doença. (...) Apenas, aí também, é preciso explicar porque, em um dado momento, numa era histórica cultura dada, aconteceram transformações sob os regimes políticos de uma sociedade. Por que? Existe uma maneira idêntica de colocar o problema que é o problema médico, o problema da higiene, o problema da saúde como política de uma sociedade em termos comparáveis, e então encontraremos, no nível das práticas, alguma coisa de comum que corresponde a essa coerência, ou a esse conjunto que, no nível dos conceitos, é detectada por Foucault. No nível das práticas, isso não se chamará mais épistemê, isso terá outro nome. Haverá uma espécie de coerência das práticas. ${ }^{70}$

Mais que a fidelidade a tal ou tal axioma metodológico, emprestado de Bachelard, Fleck ou de Canguilhem, para Braunstein a o que a antiga e a nova escola de epistemologia histórica compartilham é um certo estilo de pensar e fazer a história das ciências. "tentei empregar essa expressão a propósito somente do que se chamava em geral de french network, french debate, french school, em inglês, já que eram sobretudo historiadores estrangeiros que falavam disso", nos disse Braunstein" 71 "Isso me parece bastante eficaz, na medida em que há evidentemente um ar de família." A noção não é completamente original, posto que a noção de estilo se tornou bastante conhecida em história das ciências após os trabalhos de Alistair Crombie, Ian Hacking e mesmo do próprio Fleck. Mesmo seu emprego não é completamente

\footnotetext{
${ }^{69}$ Ibidem, p 237.

${ }^{70}$ Ibidem, p 260.

${ }^{71}$ ALMEIDA e CAMOLEZI, “Entretien avec Jean-François Braunstein”, p. 162.
} 
original. Gérard Lebrun, por exemplo, deu o nome de "estilo epistemológico" ao tipo de historiografia científica interessada "no modo próprio a cada ciência para a produção de enunciados ou regras que possibilitam sua edificação"72. A novidade trazida por Braunstein é o fato de que ele conseguiu definir o "estilo francês de história das ciências" a partir de quatro traços fundamentais dessa epistemologia ${ }^{73}$ : ela parte de uma reflexão sobre as ciências (ou seja, ele é a posteriori, e nunca normativa, em relação às ciências); essa reflexão é histórica (a filosofia das ciências “à la francesa”, diz Braunstein, "é história das ciências"); essa história é crítica (sob dois aspectos: em primeiro lugar, ela avalia e julga aquilo que estuda, e em segundo, ela julga a partir de um sentido de recorrência); por fim, essa crítica é igualmente uma história da racionalidade (fosse pelas ciências particulares, a razão jamais tomaria conhecimento de si, pois, nos diz Canguilhem, "ela não está fundada na verdade divina ou na exigência de unidade das regras do entendimento"). Assim, a noção de estilo, que não conhece fronteiras geográficas, permitiria minimizar as diferenças, mas sem suprimi-las, e universalizar o tema da epistemologia histórica, ao mesmo tempo que individualiza os autores que compartilham esse estilo.

\footnotetext{
${ }^{72}$ LEBRUN, A ideia de epistemologia, p. 135.

${ }^{73}$ BRAUNSTEIN, "Historical epistemology, old and new", p. 38-40, passim.
} 


\title{
À guisa de conclusão
}

$\mathrm{Na}$ França, onde a História das Ciências conheceu um desenvolvimento tão impressionante quanto singular desde o século XVIII, a maior parte desse trabalho historiográfico ainda está sob o encargo de filósofos com formação em alguma disciplina científica. Falando sobre a obra de Bachelard, Jean Gayon, um caso típico de filósofo com formação científica (Biologia) dedicado à História das Ciências, identificou a seguinte dificuldade:

\begin{abstract}
Ainda que os historiadores das ciências tenham emprestado de Gaston Bachelard conceitos que julgaram fecundos, eles raramente se aventuram a estabelecer um julgamento sobre sua obra do ponto de vista da história das ciências. São quase sempre filósofos que se entregam a esse exercício. Às vezes são eles mesmos praticantes da história das ciências, às vezes não. Mesmo tais estudos são pouco numerosos. Se quase não existem estudos sobre Bachelard que não se refiram à sua reflexão filosófica sobre a ciência e, eventualmente, ao papel desempenhado pela história, raros são os estudos que tratam no seu conjunto a questão da relação de Bachelard com a história das ciências. Essa questão é delicada, tanto quanto o papel conferido por Bachelard a essa disciplina é mercenário. ${ }^{1}$
\end{abstract}

Nesse artigo, Jean Gayon classifica a obra de Bachelard a partir dos grandes temas já reconhecidos por uma longa tradição de comentadores. Assim, identifica dois ensaios de natureza metafísica $^{2}$, doze sobre obras poéticas ${ }^{3}$ e doze sobre ciências ${ }^{4}$, sendo que, desses, apenas um livro pode ser considerado verdadeiramente um estudo de história das ciências: Étude sur l'évolution d'un problème de physique: la propagation thermique dans les solides, publicado em 1928, tese complementar de doutorado em Filosofia de Bachelard, concluído um ano antes sob a orientação

\footnotetext{
${ }^{1}$ GAYON, Jean. "Bachelard et l'histoire des sciences", p. 51-52.

${ }^{2}$ L'intuition de l'instant (1932), La dialectique de la durée (1936).

${ }^{3}$ La psychanalyse du feu (1938), Lautréamont (1940), L'eau et les rêves. Essai sur l'imagination de la matière (1942), L'air et les songes. Essai sur l'imagination du mouvement (1943), La terre et les rêveries de la volonté. Essai sur l'imagination des forces (1948), La terre et les rêveries du repos. Essai sur les images de l'intimité (1948), Paysages. Études pour quinze burins d'Albert Flocon (1950), La poétique de l'espace (1957), La poétique de la rêverie (1960), La flamme d'une chandelle (1961), Le droit de rêver (1970, póstumo), Fragments d'une poétique du feu (1988, póstumo).

${ }^{4}$ Essai sur la connaissance approchée (1928), Étude sur l'évolution d'un problème de physique : la propagation thermique dans les solides (1928), La valeur indutive de la Relativité (1929), Le pluralisme cohérent de la chimie moderne (1932), Les intuitions atomistiques (1935), L'expérience de l'espace dans la physique contemporaine (1938), Le nouvel esprit scientifique. Contribuition à une psychanalise de la connaissance objective (1938), La philosophie du non. Essai d'une philosophie du Nouvel Esprit Scintifique (1940), Le rationalisme appliqué (1949), L'activité rationaliste de la physique contemporaine (1951), Études (1970, póstumo), L'engagement rationaliste (1972, póstumo)
} 
de Léon Brunschivicg. Essa classificação tão didática de Gayon serve apenas para determinar o conjunto das obras que devem ser levadas em consideração (isto é, os doze livros sobre ciências) antes de levantar o grave problema da obra de Bachelard como pertencente ao gênero "História das Ciências" e, consequentemente, a identificação de Bachelard como um historiador. Aliás, Gayon propõe uma situação ideal para ilustrar as condições em que conduzirá tal investigação. Certamente valerá a pena descrevê-la aqui (apesar da sua extensão), para demonstrar o percurso metodológico desse historiador das ciências tão empenhado em questionar os limites da historiografia, que ele compreende não apenas como "a literatura histórica", mas como "uma metadisciplina cujo objeto (...) é designado pela expressão 'epistemologia da história"”:

Imaginemos que não conhecemos nada de Bachelard, senão que ele viveu na França de 1884 a 1962. Ignoremos em particular as seguintes informações: que Bachelard era titular de uma licence de Matemática e agrégé de Filosofia, que ele realizou sua tese de Filosofia sob a direção de Léon Brunschivicg, que em 1940 ele sucedeu Abel Rey como professor titular da cadeira de "História e Filosofia das Ciências", da Faculté de Lettres da Sorbonne e que ele foi diretor do Instituto de História das Ciências e das Técnicas (instituto fundado em 1932 pela Université de Paris, por muito tempo o único do seu gênero na França). Ignoremos também, claro, a marca profunda que Bachelard deixou na cultura francesa, senão mundial. Nessa experiência de pensamento, nossa única fonte de informação é constituída pelas publicações de Gaston Bachelard. A Academia estrangeira a que nós pertencemos carece dramaticamente de informações sobre esse autor francês de quem ouviu falar as melhores coisas possíveis e gostaria de saber se seria justificável abrir um título "Bachelard" num fascículo sobre "As Grandes Figuras da História das Ciências", que ela pretende publicar. Infelizmente, nenhuma informação biográfica ou comentário sobre o autor está disponível. Por milagre, todos os impressos foram preservados. O relatório, enfim, deve ser feito rapidamente, o que exclui uma leitura atenta e detalhada dessa obra tão abundante. É preciso, logo, determinar a amplidão e a qualidade das contribuições do autor ao domínio da História das Ciências, correndo o risco de faltar com os aspectos da obra que teriam um valor intrínseco para outros campos de conhecimento e reflexão. ${ }^{5}$

Ficamos consternados ao perceber que essa caricatura está sendo adotada como procedimento para leitura dos escritos de Canguilhem nesse momento em que eles se tornam cada vez mais acessíveis aos pesquisadores, tanto pela abertura dos seus arquivos pessoais e de trabalho, quanto pela publicação das suas obras completas. Existe uma razão para falarmos de Canguilhem como um combatente da história das ciências e também porque demos ao problema da historicização das ciências na sua obra o caráter de um processo. Desde o primeiro capítulo, definimos nossa pesquisa por oposição àquela sanha classificatória, para afirmar que o conteúdo,

\footnotetext{
${ }^{5}$ GAYON, Op. cit., p. 56-57.
} 
a originalidade e a vitalidade da teoria canguilhemiana da história das ciências só podem ser bem apreendidos quando sua obra é lida no interior de uma história, mais ainda, quando ela é percebida como a síntese histórica de uma cultura intelectual.

Canguilhem jamais deixou de se ver como um filósofo e jamais deixou de ver a história das ciências como uma tarefa da sua reflexão filosófica. Mas, a partir do momento em que Canguilhem passou a refletir sobre as relações entre as regras específicas da produção do conhecimento verdadeiro e as condições culturais e sociais de tal produção, essa "tarefa" deixou de ser um momento subordinado, para se tornar uma disciplina com dignidade filosófica própria. E, ao fazê-lo, contribui para o reconhecimento da autonomia da história das ciências no campo dos saberes, autonomia como disciplina criadora dos seus próprios objetos, reconhecidos enquanto tal a partir do momento em que uma teoria elaborou os métodos para investiga-los. Não espanta que, num dos últimos atos da sua carreira de historiador das ciências, Canguilhem tenha invertido o sentido do problema que o ocupava nos seus anos de Inspetor Geral e se perguntado sobre "o papel da epistemologia na historiografia científica contemporânea" - título dado à introdução do livro Ideologia e racionalidade na história das ciências da vida, originalmente texto de uma conferência apresentada em Barcelona em 1975.

Como dissemos, a história da ciência "como gênero literário" nasceu, como não poderia deixar de ser, alheia a qualquer reflexão epistemológica. Segundo Canguilhem, mesmo quando Sprengel, na introdução à sua Histoire de la Médecine, faz alusão à filosofia Crítica, “é como se se tratasse de uma doutrina de que estavam impregnados alguns médicos (...) e de modo algum como se fosse um instrumento novo e eficaz de valorização ou desvalorização dos métodos do saber" ${ }^{\prime 6}$. Mas, se não podia reprovar os historiadores das ciências dos séculos XVIII e XIX por essa ausência de referência à epistemologia, Canguilhem não perdoou a mesma falha nos historiadores contemporâneos. Isso porque, sem recurso à epistemologia, o historiador não tem como compreender os meios de constituição próprios de um discurso com pretensão de verdade. "A história das ciências", escreveu Canguilhem, "é a tomada de consciência explícita, exposta como teoria, do fato que as ciências são discursos críticos e progressivos para determinação daquilo que, na experiência, deve ser tomado como real”"7. Bem compreendida, essa definição também nos permite enxergar o efeito de novidade produzido pela sua obra sobre a disciplina, desde que concedamos a Canguilhem aquilo que é frequentemente negado a Bachelard: o cuidado de inserir seus textos em seus contextos intelectuais.

Esperamos que os elementos trazidos tenham sido em número e clareza suficientes

\footnotetext{
${ }^{6}$ CANGUILHEM, "Le rôle de l'épistémologie...", p. 12.

${ }^{7}$ CANGUILHEM, "L'objet de l'histoire des sciences", p. 17.
} 
para deixar claro que o fato de que a teoria da história das ciências de Canguilhem ter sido elaborada no interior de uma reflexão filosófica não constitui razão intelectual para desqualificálo enquanto historiador. François Hartog falou que Michel Foucault, Claude Lévi-Strauss e Paul Ricoeur, para buscarmos exemplos contemporâneos a Canguilhem, pertencem à linhagem dos outsiders da história: “Aí encontramos filósofos, intelectuais, escritores que, no total, foram mais relevantes nos debates e interrogações sobre aquilo que era, não era, poderia ser a história que gerações de honestos insiders" ${ }^{\prime 8}$. E, nessa corte, Canguilhem certamente tem o seu lugar.

Nem sempre foi fato evidente que as ciências possuem uma história, e muito menos que a compreensão dos problemas atuais das ciências exige uma abordagem histórica: essas são conquistas do século XX. Apesar dos diferentes matizes, poucos pesquisadores discordariam do diagnóstico geral de Lorraine Daston, para quem, desde a década de 70, "três escolas historiográficas dominaram a história das ciências: a escola filosófica, a escola sociológica e a escola histórica"9. E, em cada uma dessas escolas, a História das Ciências construiu objetos próprios e desenvolveu características próprias, que se, por um lado, conduziram muitos pesquisadores ao entrincheiramento nas especialidades, por outro, permitiram o alargamento da nossa compreensão do que é e do que pode ser a História das Ciências. Embora não possamos dizer que esse alargamento tenha sido suficiente para estabelecer a História das Ciências sobre bases verdadeiramente interdisciplinares, as obras mais vibrantes da historiografia científica do século XX são aquelas resultantes de esforços teóricos de conciliação dos objetivos e de superação das limitações daquelas três escolas. Acreditamos serem essas as grandes conquistas da obra historiográfica de Canguilhem. Por isso, àquelas quatro características indicadas por Braunstein para definir o estilo francês de história das ciências, acreditamos ser necessário adicionar uma ideia destacada por Lorraine Daston em 1996, quando apresentou seu programa de epistemologia histórica ao público parisiense. Uma ideia que, não temos qualquer receio de dizer, poderia facilmente ser enxertada em qualquer texto de Canguilhem sobre a teoria da história das ciências. Trata-se da denúncia do “caráter particularmente estéril da oposição entre o 'social' e o 'racional' que tanto preocupou os historiadores, os sociólogos e os filósofos das ciências nos últimos vintes anos"10. Compartilhamos do seu estranhamento diante "dessa ideia estranha, mas difundida, de que historicizar equivale a invalidar".

Parece que, nesse debate de múltiplas facetas, os diversos protagonistas compartilham implicitamente duas premissas: primeiramente, a de que o racional e o social são tão pouco misturáveis como a água e o óleo; e em

\footnotetext{
${ }^{8}$ HARTOG, "Prefácio". In: IEGELSKI, Astronomia das constelações humanas, p. 19.

${ }^{9}$ DASTON, "Une histoire de l'objectivité scientifique", p. 115.

${ }^{10}$ Ibidem, p. 124.
} 
seguida, o fato de que tornar históricas categorias fundamentais da ciência equivale ipso facto a contestar sua validade. Do meu ponto de vista, nenhuma dessas asserções é defensável. Pretender que uma teoria científica ou que uma técnica tenha origens, significações ou funções sociais nada diz sobre sua validade: os conceitos do cálculo das probabilidades podem muito bem ter sua fonte no seio das práticas econômicas e legais pré-modernas do contrato aleatório, a nomenclatura botânica de Lineu poderia ter sido corroborada pela doutrina deveras estranha da frugalidade divina e da autarquia nacional, Darwin pôde esperar que suas pesquisas sobre a inteligência e as emoções dos animais dariam argumentos aos movimentos opostos à vivissecção na Inglaterra vitoriana. Esses enraizamentos sociais não invalidam tanto quanto não fortalecem a teoria das probabilidades, nem a classificação lineana, nem a teoria darwiniana da evolução. ${ }^{11}$

${ }^{11}$ Idem. 


\section{REFERÊNCIAS BIBLIOGRÁFICAS:}

\section{Textos de Canguilhem:}

Indicamos os textos de Canguilhem mais citados em nossa tese. A lista mais completa da produção bibliográfica de Canguilhem foi elaborada por Camille Limoges e pode ser conferida no documento anexo a esse trabalho.

CANGUILHEM, Georges. "De la science et de la contre-science". In: Hommage à Jean Hyppolite. Paris: PUF, 1971.

. Du développement à l'évolution au XIX siècle. Paris: Presses Universitaires de France, 2003. - (Quadrige: Grands Textes).

. "La décadence de l'idée de progrès". In: Revue de métaphysique et de morale, n. 92, 1987, pp. 437-454.

juillet 1967.

. “Mort de l'Homme ou épuisement du Cogito?”. In: Critique, n 242,

. "Nécessité de la diffusion scientifique". In: Revue de l'enseignement supérieur, n. 3, pp. 5-15.

. Écrits sur la médecine ("L'idée de nature dans la pensée et la pratique médicales"; "Une pédagogie de la guérison est-elle possible”). Paris: Seuil, 2002.

- Études d'histoire et de philosophie des sciences ("Physiologie et pathologie de la glande thyroïde au xixe siècle"; "Thérapeutique, Expérimentation, Responsabilité"; "L'histoire des sciences dans l'œuvre épistémologique de Gaston Bachelard"; "La constitution de la physiologie comme science"; "Le concept et la vie"). $2^{a}$ ed. aum. Paris: Librairie Philosophique J. Vrin, 2002. - (Problemes \& Controverses).

. Idéologie et rationalité dans l'histoire des sciences de la vie ("Qu'estce qu'une idéologie scientifique?"; "L'histoire des sciences de la vie depuis Darwin"; "La question de la normalité dans l'histoire de la pensée biologique"; "La fin des théories médicales au xjxe siècle : le rôle de la bactériologie"; "Le rôle de l'epistemologie dans l'historiographie scientifique";). $2^{\mathrm{a}}$ ed. rev. e cor. Paris: Librairie Philosophique J. Vrin, 2000. - (Problemes \& Controverses). 
. Introduction à l'histoire des sciences: Vol. I. "Eléments et Instruments".

Vol. II. “Objet, méthode, exemples”. Paris: Hachette, 1970-1971.

. La connaissance de la vie. $4^{\mathrm{a}}$ ed. Paris: Vrin, 1992.

. La formation du concept de réflexe aux XVIIe et XVIIIe siècles. Paris:

PUF.

. Le fascisme et les paysans. Paris: Comité de vigilance des intellectuels anti-fascistes, 1935.

. Le normal et le pathologique, Paris: PUF, 2002.

Euvres Complètes. Écrits philosophiques et politiques, 1926-1939, tome I. Jean-François Braunstein e Yves Schwartz (Orgs.). Paris: Vrin, 2011.

. Euvres Complètes. Résistance, philosophie biologique et histoire des sciences 1940-1965, tome IV. Camille Limoges (Org.). Paris: Vrin, 2015.

\section{Bibliografia geral:}

ALMEIDA, Tiago Santos; CAMOLEZI, Marcos. Entrevista com Jean-François Braunstein. Intelligere, [S.1.], v. 2, n. 1, p. 156-171, maio 2016.

ALTHUSSER Louis, 1964, «Présentation », dans « La philosophie de la science de Georges Canguilhem », in La pensée, n. 113, pp. 50-54.

AYRES, José Ricardo de Carvalho Mesquita. Epidemiologia e emancipação. Rio de Janeiro: Hucitec/ABRASCO, 1995.

AYRES, José Ricardo de Carvalho Mesquita. Georges Canguilhem e a construção do campo da Saúde Coletiva brasileira. Intelligere, [S.1.], v. 2, n. 1, p. 139-155, may 2016. ISSN 2447-9020. Disponível em: $<$ http://www.revistas.usp.br/revistaintelligere/article/view/115732/113281>.

BADIOU Alain, 1993, «Y a-t-il une théorie du sujet chez Georges Canguilhem ? », dans Georges Canguilhem, philosophe, historien des sciences, Paris, Albin Michel, pp. 295304.

BRAUNSTEIN Jean-François, 2000, " Canguilhem avant Canguilhem », dans Revue d'histoire des sciences, tome 53, $\mathrm{n}^{\circ} 1$, pp. 9-26. 
BRAUNSTEIN, Jean-François, "La critique canguilhemienne de la psychologie". In: Bulletin de psychologie, Groupe d etude de psychologie, 1999, 52 , pp.181-190.

BRAUNSTEIN, Jean-François. "Deux philosophies de la médecine : Canguilhem et Fleck”. In: Fagot-Largeault, Anne, Debru, Claude. Philosophie et Médecine. Paris: Vrin, 2008.

BRAUNSTEIN, Jean-François. "Deux visions du normal et du pathologique". In: Hôpitaux magazine, 2007, 4 , pp.13-14.

BRAUNSTEIN, Jean-François. "Fleck, Canguilhem, Foucault". I. Löwy, N. Jas. "Genesis and Development of a Scientific Fact" Revisited: Foundations, Fertility and Relevance of Ludwik Fleck's Thought. Paris, Collegium Helveticum, 2009.

BRAUNSTEIN, Jean-François. Canguilhem, histoire des sciences et politique du vivant. Paris: PUF, 2007.

BRAUNSTEIN, Jean-François. La philosophie de la médecine d'Auguste Comte. Vierge Mère, vaches folles et morts vivants. Paris: PUF, 2009.

COMTE, Auguste. Discurso sobre o espírito positivo. Tradução de Maria Ermantina Galvão. São Paulo: Martins Fontes, 1990.

CONDÉ, Mauro Lucio Leitão. Entre o normal e o patológico: Ludwik Fleck, Georges Canguilhem e a gênese da epistemologia histórica. Intelligere, [S.1.], v. 2, n. 1, p. 51-67, may 2016. ISSN 2447-9020. Disponível em: $<$ http://www.revistas.usp.br/revistaintelligere/article/view/114460/113274>.

CONRY, Yvette "Combats pour l'histoire des sciences: lettre ouverte aux historiens de mentalités". In: Revue de Synthèse, t. CIV, 111-112 (julho 1983).

DAGOGNET François, 1985, « Une œuvre en trois temps », dans Révue de métaphysique et de morale, n. 90.1, Paris, Armand Colin, pp. 29-38.

DAGOGNET François, 1997, Georges Canguilhem, philosophe de la vie, Le PlessisRobinson (Essonne), Institut Synthélabo.

DAGOGNET, François. Georges Canguilhem, philosophe de la vie. Paris: Les Empêcheurs de penser en rond, 1997.

DAGOGNET, François. Georges Canguilhem, philosophe de la vie. Paris: Les Empêcheurs de penser en rond, 1997. 
DEBRU Claude, 2004, « Georges Canguilhem et Kurt Goldstein », dans Science et 329 non-science, Paris, Éditions Rue d’Ulm, pp. 49-63.

DELAPORTE François (dir.), 1994, A vital Rationalist, Selected Writings from Georges Canguilhem, New York, Zone Books.

DELAPORTE, F. "L'erreur Chagas". In: . Figures de la médecine. Paris: Les Éditions du CERF, 2009.

DELAPORTE, F. A doença de Chagas: história de uma calamidade continental. Trad. de Carmem Cecília da Rosa Pereira e de Leonora Portela de Assis. Ribeirão Preto: Holos, 2003.

DELAPORTE, François. “Chagas, a lógica e a descoberta”. Manguinhos, Rio de Janeiro, vol.1, n.2, p. 39-53. 1995.

DELAPORTE, François. Le seconde règne de la nature: essai sur les questions de végétalité au XVIIIe siècle. Paris: Édition des archives contemporaines, 2011.

DREYFUS, Hubert L. e RABINOW, Paul. Michel Foucault: beyond structuralism and hermeneutics. $2^{\text {a }}$ ed. aum. Chicago: The University of Chicago Press, 1983.

FEE, Elizabeth e BROWN, Theodore M (ed.). Making medical history: the life and times of Henry E. Sigerist. The Johns Hopkins University Press: Baltimore/Londres, 1997.

FOUCAULT Michel, 1985, « La vie, l'expérience et la science », dans Revue de métaphysique et de morale, n. 90.1, Paris, Armand Colin , pp. 3-14.

FOUCAULT, Michel. "Le souci de la vérité”. In: Dits et écrits (1976-1988), t. II. Paris: Gallimard, 2001.

FOUCAULT, Michel. A arqueologia do saber. Tradução de Luiz Felipe Baeta Neves. $3^{\mathrm{a}}$ ed. Rio de Janeiro: Forense Universitária, 1987. - (Campo Teórico).

FOUCAULT, Michel. A posição de Cuvier na história da Biologia. In:

Arqueologia das ciências e história dos sistemas de pensamento. Manoel Barros da Motta (org.). Tradução de Elisa Monteiro. Rio de Janeiro: Forense Universitária, 2000. p. 193229. - (Ditos e Escritos; II).

FOUCAULT, Michel. A vida: a Experiência e a Ciência. In: . Arqueologia das ciências e história dos sistemas de pensamento. Manoel Barros da Motta (org.). Tradução de Elisa Monteiro. Rio de Janeiro: Forense Universitária, 2000. p. 353-366. (Ditos e Escritos; II). 
FOUCAULT, Michel. Arqueologia das ciências e história dos sistemas de pensamento. Manoel Barros da Motta (org.). Tradução de Elisa Monteiro. Rio de Janeiro: Forense Universitária, 2000, p. 335-351. - (Ditos e Escritos; II). 143

FOUCAULT, Michel. Arqueologia das ciências e história dos sistemas de pensamento. Manoel Barros da Motta (org.). Tradução de Elisa Monteiro. Rio de Janeiro: Forense Universitária, 2000, p. 335-351. - (Ditos e Escritos; II).

FOUCAULT, Michel. As palavras e as coisas: uma arqueologia das ciências humanas. Tradução de Salma Tannus Muchail. $8^{\text {a }}$ ed. São Paulo: Martins Fontes, 1999. - (Tópicos).

FOUCAULT, Michel. O que são as Luzes?. In: Arqueologia das ciências e história dos sistemas de pensamento. Manoel Barros da Motta (org.). Tradução de Elisa Monteiro. Rio de Janeiro: Forense Universitária, 2000. p. 334-351. - (Ditos e Escritos; II).

FOUCAULT, Michel. Resposta a uma questão. Tempo Brasileiro - Epistemologia: a teoria das ciências questionada por Bachelard, Miller, Canguilhem, Foucault. $2^{\mathrm{a}}$ ed. Rio de Janeiro, n. 28, p. 57-81, jan/mar 1972.

FOUCAULT, Michel. Sobre a arqueologia das ciências. Resposta ao Círculo de Epistemologia. In: Arqueologia das ciências e história dos sistemas de pensamento. Manoel Barros da Motta (org.). Tradução de Elisa Monteiro. Rio de Janeiro: Forense Universitária, 2000. p. 83-117. - (Ditos e Escritos; II).

FOUCAULT, Michel. Sobre as maneiras de escrever a História. In: Arqueologia das ciências e história dos sistemas de pensamento. Manoel Barros da Motta (org.). Tradução de Elisa Monteiro. Rio de Janeiro: Forense Universitária, 2000. p. 6277. - (Ditos e Escritos; II).

GARCÍA, Francisco Vázquez. Senderos encontrados: Canguilhem y la escuela de los Annales. Intelligere, [S.1.], v. 2, n. 1, p. 36-50, may 2016. ISSN 2447-9020. Disponível em: <http://www.revistas.usp.br/revistaintelligere/article/view/110860/113276>.

GAYON Jean, 2000, « Le concept d'individualité dans la philosophie biologique de Georges Canguilhem ", dans Lectures de Georges Canguilhem. Le Normal et le pathologique, Fontenay-aux-Roses, ENS Éditions, pp. 19-47.

GAYON, Jean. Bachelard et l'histoire des sciences. In: WUNENBURGER, JeanJacques (org.). Bachelard et l'epistemologie française. Paris: Presses Universitaires de France, 2003. p. 51-114. - (Débats Philosophiques).

GIL, Didier. Bachelard et la culture scientifique. Paris: Presses Universitaires de France, 1993. - (Philosophies; 43). 
GRANGER, Gilles-Gaston. A ciência e as ciências. Tradução de Roberto Leal Ferreira. São Paulo: Editora UNESP, 1994. - (Ariadne).

GUALANDI, Alberto. Le problème de la vérité scientifique dans la philosophie française contemporaine : la rupture et l'événement. Paris : L'Harmattan, 1998. - (La Philosophie en commum).

GUTTING, Gary. Fin-de-siècle: the professors of the Republic. In: French philosophy in the twentieth century. Cambridge: Cambridge University Press, 2001. p. 03- 25. - (Modern European Philosophy).

GUTTING, Gary. Thomas Kuhn and French philosophy of science. In. NICKLES, Thomas. Thomas Kuhn. Cambridge: Cambridge University Press, 2003, p. 45-64. (Contemporary Philosophy in Focus).

HARTOG, François. "O olhar distanciado. Lévi-Strauss e a história”, trad. Temístocles Cezar, Topoi, [vol.] 7, 12 (2006): 12 (9-24).

HUISMAN, Frank e WARNER, John Harley. Locating Medical History. The Stories and Their Meanings. Baltimore/Londres: Johns Hopkins University Press, 2004.

IEGELSKI, Francine. Astronomia das constelações humanas: Claude Lévi-Strauss e a História. São Paulo: Humanitas, 2016 (no prelo).

KANT, Immanuel. Crítica da razão pura. Tradução de Manuela Pinto dos Santos e Alexandre Fradique Mourão. $4^{\mathrm{a}}$ ed. Lisboa: Fundação Calouste Gulbenkian, 1997.

KOYRÉ, Alexandre. Da influência das concepções filosóficas sobre a evolução das teorias científicas. In: Estudos de história do pensamento filosófico. Tradução de Maria de Lourdes Menezes. Rio de Janeiro: Forense Universitária, 1991, p. 201-214. - (Campo Teórico).

KOYRÉ, Alexandre. Du monde close à l'univers infini. Tradução de Raissa Tarr. Paris: Galimard, 2003a.- (Tel; 129).

KOYRÉ, Alexandre. Études galiléennes. Paris : Hermann et Cie, 1939. - (Histoire de la Pensée).

KOYRÉ, Alexandre. Orientation et projets de recherches. In: Études d'histoire de la pensée scientifique. Paris: Galimard, 2003b. p. 11-15. - (Tel; 92).

KOYRÉ, Alexandre. Perspectives sur l'histoire des sciences. In: . Études d'histoire de la pensée scientifique. Paris: Galimard, 2003b. p. 390-399. - (Tel; 92). 
KROPF, S. P. Doença de Chagas, doença do Brasil: ciência, saúde e nação (1909 - 1962). Rio de Janeiro: Ed. FIOCRUZ, 2009.

KROPF, Simone Petraglia. "Carlos Chagas e os debates e controvérsias sobre a doença do Brasil (1909 - 1923)". História, Ciências, Saúde - Manguinhos, Rio de Janeiro, v. 16, supl.1, jul. 2009.

KUHN, Thomas S. A estrutura das revoluções científicas. Tradução de Beatriz Vianna Boeira e Nelson Boeira. $5^{\mathrm{a}}$ ed. São Paulo: Editora Perspectiva, 2000. - (Debates; 115).

KUHN, Thomas S. A estrutura das revoluções científicas. Tradução de Beatriz Vianna Boeira e Nelson Boeira. $5^{\mathrm{a}}$ ed. São Paulo: Editora Perspectiva, 2000. - (Debates; 115).

LE BLANC, Guillaume. Canguilhem et les normes. Paris: PUF, 1998.

LE BLANC, Guillaume. La Vie humaine: Anthropologie et biologie chez Georges Canguilhem. Paris: PUF, 2002.

LE BLANC, Guillaume. Lectures de Canguilhem. Le normal et le pathologique. Paris: ENS Éditions, 2002.

LE BLANC, Guillaume. Les maladies de l'homme normal. Bègles: Ed. Du Passant, 2004.

LEBRUN, Gérard. A idéia de epistemología. In: A filosofía e sua história. Trad. de Maria Adriana Camargo Cappello. São Paulo: Cosac Naify, 2006, p. 129-144.

LECOURT Dominique, 1969, L'épistémologie historique de Gaston Bachelard, éd. 2002, Paris, Vrin.

LECOURT Dominique, 1972, Pour une critique de l'épistémologie (Bachelard, 330 Canguilhem, Foucault), Paris, Maspero.

LECOURT, Dominique. L'epistemologie historique de Gaston Bachelard. $11^{\mathrm{a}} \mathrm{ed}$. aum. Paris: Librairie Philosophique J. Vrin, 2002. - (Bibliothéque d'histoire de la philosophie).

LECOURT, Dominique. Pour une critique de l'épistémologie. Paris: Maspero, 1972.

LIMOGES Camille, 1994, «Critical Bibliography », dans Delaporte, 1994, op. cit., 2e partie, pp. 386-441.

LIMOGES Camille, 2012, "L'épistémologie historique dans l'itinéraire intellectuel de Georges Canguilhem », dans Epistemology and History From Bachelard and Canguilhem 
to Today's History of Science, Berlin, Max-Planck-Institut für Wissenchaftsgeschichte, pp. 53-66.

MACHEREY Pierre, 1964, « La philosophie de la science de Georges Canguilhem, Epistemologie et histoire des sciences », présentation par Louis Althusser, dans La Pensée, nouvelle série, n. 113, février 1964, pp. 50-74.

MACHEREY Pierre, 1996, « Georges Canguilhem : un style de pensée », dans Cahiers philosophiques, n. 69, décembre 1996, Paris, C.N.D.P., pp. 47-56.

MACHEREY, Pierre. De Canguilhem à Canguilhem em passant par Foucault. In: GEORGES CANGUILHEM, philosophe, historien des sciences., 1990, Paris. Actes du Colloque (6-7-8 décembre 1990). Paris: Albin Michel, 1993. p. 286-294. - (Bibliothèque du Collège international de philosophie).

METZGER, Hélène. La philosophie d'Émile Meyerson et l'histoire des sciences. In: . La méthode philosophique en histoire des sciences. Paris: Fayard, 1987.

MEYERSON, Émile. La déduction relativiste. Paris: Payot, 1925.

OWEN, David. Maturity and Modernity: Nietzsche, Weber, Foucault and the ambivalence of reason. Londres: Routledge, 1994.

POLANYI, Michael. Science, faith and society: a searching examination of the meaning and nature of scientific inquiry. $2^{\mathrm{a}}$ ed. aum. Chicago: The University of Chicago Press, 1964.

QUEIROZ, Francisco Assis. Ciência e não-ciência ou as "duas culturas": dominação, quase hostilidade e quase diálogo. Intelligere, [S.1.], v. 2, n. 1, p. 129-138, may 2016. ISSN 2447-9020. Disponível em: <http://www.revistas.usp.br/revistaintelligere/article/view/114511/113279>.

RAMOS, Maurício de Carvalho. O conceito epistemológico histórico de nostoc a partir de uma leitura indiciária de A teoria celular de George Canguilhem. Intelligere, [S.1.], v. 2, n. 1, p. 112-128, may 2016. ISSN 2447-9020. Disponível em: $<\underline{\text { http://www.revistas.usp.br/revistaintelligere/article/view/114342>. }}$.

RENARD, G. L’épistémologie chez Georges Canguilhem. Paris: Natha, 1996.

SANTOS FILHO, Gildo Magalhães dos. A ciência é uma ideologia?. Intelligere, [S.1.], v. 2, n. 1, p. 100-111, may 2016. ISSN 2447-9020. Disponível em: <http://www.revistas.usp.br/revistaintelligere/article/view/112277/113631>. 
SALOMON-BAYET Claire, 1996, « Georges Canguilhem, le concept et l'action », dans Raison Présente, n. 119, 3e trimestre, pp. 3-15.

SALOMON-BAYET, Claire. "Histoire des sciences et histoire de la médecine". In: LAGRÉE, Michel e LEBRUN, François (Org.). Pour l'histoire de la médecine: autor de l'oeuvre de Jacques Léonard. Rennes: Presses Universitaires de Rennes, 2004.

SÉRIS, Jean-Pierre. L'histoire et la vie. In: GEORGES CANGUILHEM, philosophe, historien des sciences., 1990, Paris. Actes du Colloque (6-7-8 décembre 1990). Paris: Albin Michel, 1993. p. 90-102. - (Bibliothèque du Collège international de philosophie).

TILES, Mary. Bachelard: science and objectivity. Trowbridge: Cambridge University Press, 1984.

YOVEL, Yirmiahu. Kant and the Philosophy of History. Princeton: Princeton University Press, 1980. 
ANEXO I

(BIBLIOGRAFIA ESTABELECIDA POR CAMILLE LIMOGES) 


\section{BIBLIOGRAPHIE DES TRAVAUX DE GEORGES CANGUILHEM}

\section{Livres}

Essai sur quelques problèmes concernant le normal et le pathologique, Publications de la Faculté des Lettres de Strasbourg, 1943, no $100.2^{\circ}$ édition, Paris, Les Belles Lettres, 1950.

La Connaissance de la vie, Paris, Hachette, 1952. Nouv. éd. augmentée, Paris, Vrin, 1965.

La Formation du concept de réflexe aux XVII ${ }^{e}$ et XVIII siècles, Paris, PUF, 1955. Nouv. éd. revue, Paris, Vrin, 1977.

Le Normal et le pathologique ( $3^{\text {e }}$ édition de la thèse de 1943, augmentée de Nouvelles réflexions sur le normal et le pathologique), Paris, PUF, 1966.

Etudes d'histoire et de philosophie des Sciences, Paris, Vrin, 1968. Cinquième éd. augmentée en 1983.

Idéologie et rationalité dans l'histoire des Sciences de la vie. Nouvelles études d'histoire et de philosophie des sciences, Paris, Vrin, 1977.

\section{Recueils de textes}

Introduction à lhistoire des sciences :

Vol. I. Eléments et Instruments; textes choisis.

Vol. II. Objet, méthode, exemples; textes choisis.

En collaboration avec S. Bachelard, J. C. Cadieux, Y. Conry, O. Ducrot, J. Guillerme, P. G. Hamamdjian, R. Rashed, C. Salomon-Bayet, J. Sebestik, Paris, Hachette, 1970-1971.

\section{Préfaces}

Roger Kempf, traduction de Kant, Essai pour introduire en philosophie le concept de grandeur négative, Paris, Vrin, 1949.

Claude Bernard, Leçons sur les phénomènes de la vie communs aux animaux et aux végétaux. Réédition, Paris, Vrin, 1966.

Gaston Bachelard, Etudes, Paris, Vrin, 1970.

Gaston Bachelard, L'Engagement rationaliste, Paris, PUF, 1972.

J. B. Lamarck, Inédits, publiés par MM. Vachon, Rousseau et Laissus, Paris, Masson et Cie, 1972.

La Mathématisation des doctrines informes (Colloque de l'Institut d'Histoire des Sciences, 1970), Paris, Hermann, 1972.

François Delaporte, Le Second Règne de la nature, Paris, Flammarion, 1979.

Othmar Keel, La Généalogie de l'histopathologie, Paris, Vrin, 1979.

Henri Péquignot, Vieillir et être vieux, Paris, Vrin, 1981.

Anatomie d'un épistémologue : François Dagognet, Paris, Vrin, 1984. 


\section{Notices Commémoratives}

« Jean Cavaillès, résistant», in Bulletin de la Faculté des Lettres de Strasbourg, décembre 1945.

« Jean Cavaillès, l'homme et l'œuvre », in Mémorial de la Faculté des Lettres de Strasbourg (1939-1945), Paris, Les Belles Lettres, 1947.

《Maurice Halbwachs, l'homme et l'œuvre », in Mémorial de la Faculté des

Lettres de Strasbourg.

Vie et Mort de Jean Cavaillès (trois commémorations), Ambialet (Tarn),

P. Laleure, éd., 1976.

"Célestin Bouglé », in Annuaire de l'Association des A. E. de l'Ecole Normale Supérieure, 1978.

\section{Articles et Études}

«Descartes et la Technique », Travaux du IX Congrès International de Philosophie, Paris, Hermann, 1937, t. II.

"Activité technique et Création 》, in Communications et Discussions, Société toulousaine de philosophie, 1938, $\mathrm{II}^{\mathrm{e}}$ série.

"Commentaire du troisième chapitre de l'Evolution Créatrice», in Bulletin de la Faculté des Lettres de Strasbourg, numéros d'avril et juin, 1943.

«La théorie cellulaire en biologie », reproduit in La connaissance de la vie, 1945.

«Milieu et Normes de l'homme au travail (sur l'ouvrage de Georges Friedmann, Problèmes humains du machinisme industriel)», in Cahiers internationaux de Sociologie, 1947, vol. III.

"Notes sur la situation faite en France ì la philosophie biologique », in Revue de Métaphysique et de Morale, $\mathrm{n}^{\circ}$ de juillet-octobre 1947.

"Hegel en France», in Revue d'Histoire et de Philosophie religieuse, $1948-1949, n^{\circ} 4$.

«Le Normal et le pathologique», in Somme de Médecine Contemporaine (reproduit dans La connaissance de la vie), éd. La Diane française, 1951.

« Réflexion sur la création artistique selon Alain », in Revue de Métaphysique et de Morale, $\mathrm{n}^{\circ}$ d'avril-juin 1952

«Organisme et Modèles mécaniques. Réflexions sur la biologie cartésienne, , in Revue philosophique, $\mathrm{n}^{\circ}$ de juillet-septembre 1955.

«La pensée de René Leriche», in Revue philosophique, $\mathrm{n}^{\circ}$ de juilletseptembre 1956.

« Sur une épistémologie concordataire », in Hommage à Gaston Bachelard, Paris, PUF, 1957.

"Fontenelle, philosophe et historien des sciences 》, in Annales de l'Université de Paris, $\mathrm{n}^{\circ}$ de juillet-septembre 1957 (reproduit dans Etudes d'histoire et de philosophie des Sciences.)

"Qu'est-ce que la psychologie ? Revue de Métaphysique et de Morale, $\mathrm{n}^{\circ}$ de janvier-mars 1958 (reproduit dans Etudes d'histoire et de philosophie des Sciences).

- La philosophie biologique d'Auguste Comte et son influence en France au $\mathrm{xIx}^{\theta}$ siècle », in Bulletin de la Société française de philosophie, $\mathrm{n}^{\circ}$ spécial pour le centenaire de la mort d'Auguste Comte (reproduit dans Etudes d'histoire et de philosophie des Sciences).

« La physiologie animale au $\mathrm{xv}^{\mathrm{e}}{ }^{\mathrm{e}}$ siècle $\gg$, in Histoire générale des Sciences de René Taton, $t$. II : La science moderne, Paris, PUF, 1958.

« Physiologie et pathologie de la glande thyroïde au $\mathrm{xIx}^{\mathrm{e}}$ siècle \$, in Thalès, 
t. IX, 1958, Paris, PUF (reproduit dans Etudes d'histoire et de philosophie des Sciences).

« Les concepts de lutte pour l'existence et de sélection naturelle en 1858 : Ch. Darwin et A. R. Wallace », Conférence au Palais de la Découverte, 1959, série $\mathrm{D}, \mathrm{n}^{\circ} 61$ (reproduit dans Etudes...).

*Thérapeutique, Expérimentation, Responsabilité », in Revue de l'Enseignement Supérieur, $\mathrm{n}^{\circ}$ 2, 1959 (reproduit dans Etudes...).

《L'homme et l'animal du point de vue psychologique selon Ch. Darwin 》, in Revue d'histoire des Sciences XIII, L, 1960 (reproduit dans Etudes...).

"Nécessité de la "diffusion scientifique" », in Revue de l'Enseignement Supérieur, $\mathrm{n}^{\circ}$ II, 1961.

"Physiologie animale au $\mathrm{xIx}^{\mathrm{e}}$ siècle , in Histoire générale des Sciences, de

René Taton, t. III, $1^{\text {re }}$ partie : La science contemporaine, Paris, PUF.

« L'Ecole de Montpellier jugée par A. Comte », Scalpel n 3, 1961 (reproduit dans Etudes...).

« La monstruosité et le monstrueux », Diogène, $\mathrm{n}^{\circ} 40$ (oct.-déc. 1962) reproduit dans La connaissance de la vie, 2 "éd., Paris, Vrin.

«Du développement à l'évolution au $\mathrm{XIx}^{\mathrm{c}}$ siècle 》 (en collaboration avec

G. Lapassade, J. Piquemal, J. Ulmann) », in Thalès, t. XI, Paris, PUF, 1962.

"The role of analogies and models in biological discovery in Scientific

Change (ed. by A. C. Crombie), London, Heinemann, 1963. Le texte français est publié dans Etudes d'histoire et philosophie des Sciences.

«L'histoire des sciences dans l'œuvre épistémologique de Gaston Bachelard », in Annales de l'Université de Paris, $\mathrm{n}^{\circ} \mathrm{I}, 1963$.

"Gaston Bachelard et les philosophes », in Sciences, $\mathrm{n}^{\circ} 24$ (mars-avril) Paris, Hermann, 1963.

«Dialectique et philosophie du Non chez G. Bachelard », Revue Internationale de philosophie, $\mathrm{n}^{\circ} 66,4,1963$. (Ces trois articles concernant G. Bachelard sont reproduit dans Etudes...).

«La constitution de la physiologie comme science », Introduction historique au Traité de physiologie de Charles Kayser, t. I, Paris, Editions médicales Flammarion, 1963. (Reproduit dans Etudes...).

"L'homme de Vésale dans le monde de Copernic : 1543 », Commémoration du centenaire de la mort de Vésale, à Bruxelles, 1965. (Reproduit dans Etudes...).

* Histoire des religions et histoire des sciences dans la théorie du fétichisme chez A. Comte », Mélanges Koyré, t. II, Paris, Hermann, 1964 (reproduit dans Etudes...).

«Galilée : la signification de l'œuvre et la leçon de l'homme », Archives internationales d'histoire des sciences, $\mathrm{n}^{\circ}$ 68-69, 1965 (reproduit dans Etudes...).

"Le concept de réflexe au $\mathrm{xIx}^{\mathrm{e}}$ siècle», in Von Boerhaave bis Berger (herausgegeben von K. E. Rothschuh) G. Fischer, Stuttgart, 1964 (reproduit dans Etudes...).

"L'idée de médecine expérimentale selon Claude Bernard \$, Conférence du Palais de la Découverte, série $\mathrm{D}, \mathrm{n}^{\circ}$ 101, 1965 (reproduit dans Etudes...). "Claude Bernard et Bichat», XI Congrès international d'histoire des sciences, Varsovie-Cracovie, 1965 (reproduit dans Etudes...).

"Le tout et la partie dans la pensée biologique », in Les Etudes philosophiques, $\mathrm{n}^{\circ} 1,1966$ (reproduit dans Etudes...).

"Le concept et la vie », in Revue philosophique de Louvain, t. 64, $\mathrm{n}^{\circ} \mathrm{de}$ mai 1966 (reproduit dans Etudes...).

«Théorie et technique de l'expérimentation chez $\mathrm{Cl}$. Bernard », in Philo- 


\section{Revue de Métaphysique et de Morale}

sophie et méthodologie scientifiques de Cl. Bernard, Paris, Masson et Cie éd., 1967 (reproduit dans Etudes...).

4 Un physiologiste philosophe, Claude Bernard », in Dialogue, t. V., $\mathrm{n}^{\circ} 4$, 1967, Montréal, Canada.

"Mort de l'Homme ou épuisement du Cogito? 》 (à propos de l'ouvrage de Michel Foucault, Les mots et les choses), in Critique, $\mathrm{n}^{\circ} 242$, juillet 1967. "Biologie et Philosophie », in Contemporary philosophy, a survey, ed. R. Klibansky, La Nuova Italia editrice, Firenze, 1968, vol. II.

* La physiologie animale au $\mathrm{xviII}^{\mathrm{e}}$ siècle (revu et augmenté), in Histoire générale des Sciences, de R. Taton, t. II : La science moderne, Paris, PUF, 1968.

« Jean Hyppolite (1907-1968) », in Revue de Métaphysique et de Morale, $1969, \mathrm{n}^{\circ} 2$.

"Qu'est-ce qu'une idéologie scientifique? 》, in Organon, Revue de l'Académie polonaise des Sciences (Histoire des Sciences), Varsovie, 1970, $\mathrm{n}^{\circ} 7$ (reproduit dans Idéologie et rationalité dans l'histoire des sciences de la vie).

« De la science et de la contre-science », in Hommage à Jean Hyppolite (présenté par Michel Foucault), Paris, PUF, 1971, Coll. Epiméthée.

«Logique du vivant et histoire de la biologie », (à propos de l'ouvrage de François Jacob, La logique du vivant), in Sciences, $\mathrm{n}^{\circ} 71$, mars-avril, Paris, Hermann, 1971.

Article «Physiologie », in Encyclopaedia Universalis, Paris, 1971.

"L'histoire des sciences de la vie depuis Darwin », Rapport à la Séance inaugurale au XIII ${ }^{e}$ Congrès International d'Histoire des Sciences, Moscou, août 1971 (reproduit dans Idéologie et rationalité...).

《L'idée de nature dans la pensée et la pratique médicales », in Médecine de l'Homme, $\mathrm{n}^{\circ}$ 43, Paris, mars 1972.

Article « Régulation », in Encyclopaedia Universalis, Paris, 1972.

Article « Gaston Bachelard », in Scienteziati e Technologici contemporanei, Milano, ed. Mondadori, 1973.

Article «Auguste Comte», in Encyclopedia Est Biografica, Milano, ed. Mondadori, 1973.

\& La question de la normalité dans l'histoire de la pensée biologique, Colloque international d'histoire et philosophie des Sciences, Jywảskylẩ (Finlande), juin 1973 (reproduit dans Idéologie et rationalité...).

«La question de l'écologie : la technique ou la vie ? (Journées du protestantisme libéral, Sète, 11 novembre 1973) publié in Dialogue (Bruxelles), Cahier 22, mars 1974.

Rapport de Synthèse de la Commission no III : Qualité de la Vie, Dignité de la mort, Colloque Mondial "Biologie et Devenir de l'Homme (en Sorbonne, 19-24 septembre 1974). Ediscience, distribué par Mc Graw Hill, 1976.

Article «Vie », Encyclopaedia Universalis, Paris, 1974.

La formation du concept de régulation biologique aux $\mathrm{xvIIr}^{\mathrm{e}}$ et $\mathrm{xIx}^{\mathrm{e}}$ siècles (Séminaire interdisciplinaire du Collège de France), in L'idée de régulation dans les sciences, Paris, Maloine, 1974 (reproduit dans Idéologie et rationalité...).

" Histoire de l'Homme et Nature des choses selon A. Comte dans le " Plan des travaux scientifiques nécessaires pour réorganiser la société" (1822) », in Les Etudes philosophiques, juillet-septembre 1974.

"La fin des théories médicales au $\mathrm{XIX}^{\mathrm{e}}$ siècle : le rôle de la bactériologie », Conférence à la Faculté de Médecine de l'Université autonome de Barcelone, 1975 (reproduit dans Idéologie et rationalité). 
* Nature dénaturée et Nature naturante (à propos de l'œuvre de François Dagognet) », in Savoir, Faire, Espérer, les limites de la raison, Faculté Universitaire Saint-Louis, Bruxelles, 1976.

* Le rôle de l'épistémologie dans l'historiographie scientifique récente 》, in Scienza e Technica 1976, Milano, Mondadori, 1976 (reproduit dans Idéologie et rationalité...).

« Marc Klein, 1905-1975 », in Archives internationales d'histoire des Sciences, vol. 26, no $98,1976$.

«Souvenir de Lucien Herr », in Bulletin de la Société des Amis de l'Ecole Normale Supérieure, $\mathrm{n}^{\circ}$ 138, mars 1977.

《Une pédagogie de la guérison est-elle possible? 》, in Nouvelle Revue de Psychanalyse, XVII, 1978 : L'idée de guérison.

« Puissance et limites de la rationalité en médecine», Conférence à l'Université Louis Pasteur, à Strasbourg : Séminaire sur les fondements des sciences, pour le Centenaire de la mort de Cl. Bernard (reproduit dans Etudes d'histoire et de philosophie des Sciences, $5^{\mathrm{e}}$ éd., Paris, Vrin, 1983).

* L'Histoire des Sciences de l'organisation par de Blainville et l'Abbé Maupied », Revue d'Histoire des Sciences, XXXII-I, 1979.

"Marc Klein, historien de la biologie », Introduction au recueil posthume d'études de M. Klein : Regards d'un biologiste, Paris, Hermann, 1980.

"Le Cerveau et la pensée », Conférence en Sorbonne pour le M.U.R.S. publié dans Prospective et Santé, no 14, été 1980.

«Emile Littré, philosophe de la biologie et de la médecine», Colloque pour le premier centenaire de la mort de Littré, Paris, octobre 1981, in Revue de Synthèse, 106-108, avril-décembre, Paris, Albin-Michel, 1982.

Georges Canguilhem est membre de l'Académie internationale d'histoire des sciences, membre de l'Académie internationale d'histoire de la médecine, membre de l'Institut international de philosophie. Il a reçu en 1984 la médaille Georges Sarton. 
Revue de Métaphysique et de Morale

\section{Cours à la Faculté des Lettres de Strasbourg}

1941-1942. La causalité et le temps.

1942-1943. Les normes et le normal.

1943-1944. L'erreur.

1944-1945. La connaissance.

1945-1946. Nature et valeur du concept.

1946-1947. Philosophie et biologie.

1947-1948. Le problème de la création.

\section{Cours à Paris}

\section{A. en Sorbonne.}

1955-1956. La science et l'erreur.

1956-1957. La vision comme modèle de la connaissance.

1957-1958. L'analogue et le singulier dans la science.

1958-1959. Science et philosophie selon Auguste Comte.

1959-1960. L'œuvre scientifique de Descartes et la science du xvir ${ }^{\mathrm{e}}$ siècle.

1960-1961. Histoire de la psychologie scientifique au $\mathrm{xxx}^{\mathrm{e}}$ siècle.

1961-1962. Le statut social de la science moderne.

1962-1963. Les normes et le normal.

1967-1968. Science et idéologie dans la constitution de la psychologie.

1968-1969. L'évolutionnisme.

1969-1970. L'idéologie médicale au $x^{1} x^{\theta}$ siècle.

1970-1971. L'idéologie médicale au $\mathrm{XIX}^{\mathrm{e}}$ siècle : neurologie et psychiatrie.

B. à l'Institut d'Histoire des Sciences.

1955-1956. La préformation et l'épigenèse.

1956-1957. Concepts fondamentaux de la physiologie du système nerveux au $\mathrm{XIX}^{\mathrm{e}}$ siècle : localisation, intégration.

1957-1958. Concepts fondamentaux de la biologie au $\mathrm{xIx}^{\mathrm{e}}$ siècle : milieu intérieur et régulations.

1958-1959. Cent ans de théories transformistes.

1959-1960. Histoire de la physiologie au $\mathrm{xxx}^{\mathrm{\theta}}$ siècle.

1960-1961. La classification en histoire naturelle, d'Aristote à AntoineLaurent de Jussieu.

1961-1962. Histoire de la Tératologie depuis Etienne Geoffroy Saint-Hilaire.

1962-1963. L'évolution des idées médicales au $\mathrm{xIx}^{\mathrm{e}}$ siècle : médecine et biologie.

1963-1964. L'anatomie de Vésale à Bichat.

1964-1965. Lecture de l'Introduction à l'étude de la médecine expérimentale de Claude Bernard.

1965-1966. L'échelle des êtres et la série animale au xvrII ${ }^{\ominus}$ siècle.

1966-1967. La physiologie de Harvey à Lavoisier.

1968-1969. La biologie évolutionniste au $\mathrm{xIx}^{\mathrm{e}}$ siècle : Lamarck.

1969-1970. La médecine antique d'Hippocrate à Galien. 


\section{Bibliographie}

\section{Traductions}

Lo Normal y lo Patológico, Buenos-Ayres, Siglo veintiuno argentina editores sa, 1971 .

Das Normale und das Pathologische, München, Carl Hansen Verlag, 1974. Il normale e il patologico, Rimini, Guaraldi, 1975.

On the Normal and the Pathological, introduced by Michel Foucault; Dordrecht, Boston and London, Reidel, 1978.

O Normal e o patologico, Rio-de-Janeiro, Forense-Universitaria, 1978.

La Conoscenza della Vita, Bologna, Il Mulino, 1976.

El conocimiento de la vida, Barcelona, Editorial Anagrama, 1976.

La formación del concepto de reflejo en los siglos XVII y XVIII, ValenciaBarcelona, Juan Lliteras editor, 1975.

Ideologia e Racionalidade nas Ciências da Vida, Lisboa, Ediçôes 70, 1981.

Wissenschaftsgeschichte und Epistemologie, Gesammelte Aufsätze. Frankfurt am Main, herausgegeben von Wolf Lepenies, Suhrkamp Verlag, 1979. 